
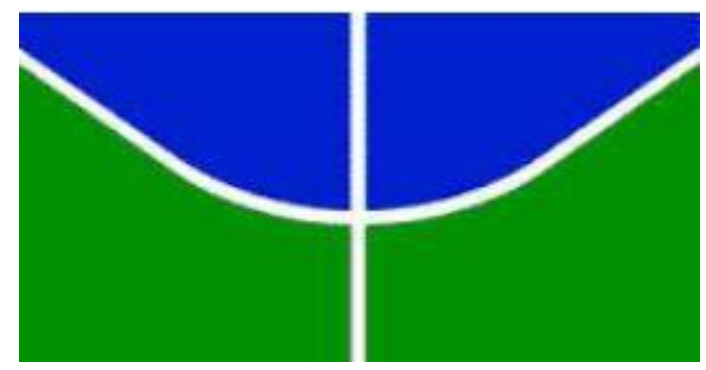

UNIVERSIDADE DE BRASÍLIA (UnB)

FACULDADE DE ECONOMIA, ADMINISTRAÇÃO,

CONTABILIDADE (FACE)

DEPARTAMENTO DE ECONOMIA

PROGRAMA DE PÓS-GRADUAÇÃO EM ECONOMIA

MESTRADO EM GESTÃO ECONÔMICA DO MEIO AMBIENTE

CONSÓRCIOS PÚBLICOS NA GESTÃo DE RESÍDUOS SÓLIDOS URBANOS NO BRASIL

WANESSA DE MATOS FIRMINO SILVA

BRASÍLIA-DF

2015 


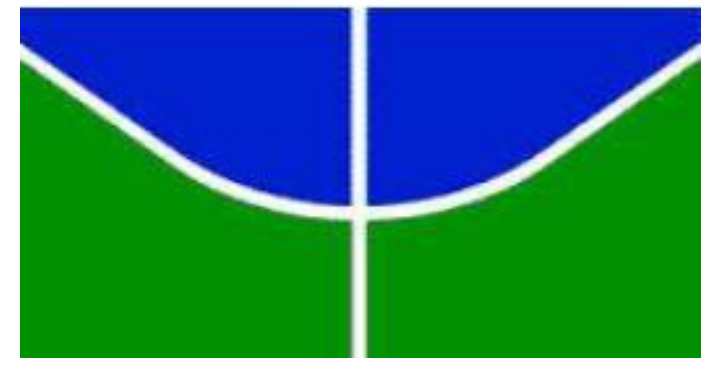

UNIVERSIDADE DE BRASÍLIA (UnB)

FACULDADE DE ECONOMIA, ADMINISTRAÇÃO,

CONTABILIDADE (FACE)

DEPARTAMENTO DE ECONOMIA

PROGRAMA DE PÓS-GRADUAÇÃO EM ECONOMIA

\section{CONSÓRCIOS PÚBLICOS NA GESTÃO DE RESÍDUOS SÓLIDOS URBANOS NO BRASIL}

WANESSA DE MATOS FIRMINO SILVA

Dissertação apresentada como requisito para a obtenção de título de Mestre em Gestão Econômica do Meio Ambiente do Programa de Pós-Graduação em Economia do Departamento de Economia da Universidade de Brasília. Orientadora: Prof ${ }^{\mathrm{a}}$. Dra ${ }^{\mathrm{a}}$. Denise Imbroisi

BRASÍLIA-DF 


\section{WANESSA DE MATOS FIRMINO SILVA}

\section{“Consórcios Públicos na Gestão de Resíduos Sólidos Urbanos no Brasil"}

Dissertação aprovada como requisito para obtenção do título de Mestre em Gestão Econômica do Meio Ambiente do Programa de Pós-Graduação em Economia Departamento de Economia da Universidade de Brasília, por intermédio do Centro de Estudos em Economia, Meio Ambiente e Agricultura (CEEMA). Comissão Examinadora formada pelos professores:

Prof ${ }^{a}$. Dra ${ }^{\mathrm{a}}$. Denise Imbroisi

Departamento de Economia da UnB

Orientadora

Prof. Dr. Jorge Madeira Nogueira

Departamento de Economia da UnB

Prof. Dr. Antônio Nascimento Junior

Departamento de Administração da UnB

Brasília, 20 de janeiro de 2015. 


\section{AGRADECIMENTOS}

Primeiro a Deus, anjos e todas as energias positivas que me fizeram começar, continuar, persistir e terminar este Mestrado, de onde tirei lições para toda a vida e me fez uma profissional, pesquisadora e pessoa melhor.

À minha família, pais e irmãs, pela paciência ao ouvir a frase "Não posso, estou estudando" e pela torcida e apoio em tudo que proponho fazer. Ao Giovanni, por sempre estar ao meu lado, por acreditar em mim e me dar os empurrões que eu preciso para seguir em frente. Eu não conseguiria nada sem o amor e o apoio de vocês.

Ao Augusto Mendonça, por me apresentar o programa de mestrado de Gestão Econômica do Meio Ambiente e à Waneska pela colaboração e atenção mesmo antes do curso começar. Aos professores Junia, Jorginho, Pedro Zuchi e Jorge Nogueira pelo conhecimento transmitido e pelas palavras de otimismo ao longo do curso.

Um especial agradecimento para a professora Denise Imbroisi, minha orientadora. Não tenho palavras para agradecer nossa parceria. Obrigada por acreditar no projeto, por me motivar e guiar durante o nosso longo ano de trabalho e pesquisa. Sem você o resultado final não seria possível.

Aos meus colegas e amigos do Banco Mundial pela compreensão e incentivo. Ao Fábio, pelas dicas nos gráficos e em especial ao Boris Utria, Deborah Wetzel e Fabiola Vasconcelos, por sempre me incentivarem a buscar conhecimento, pelo apoio e por permitirem a minha participação.

Aos meus colegas do mestrado e aos amigos Fabiana, Bruna, Sérgio, André, Leonardo, Thiago e Marcos por todas as horas que passamos resolvendo listas de exercícios intermináveis, pela lona amarela, a que nos salvava na hora do almoço, e, principalmente, pela amizade construída.

Aos especialistas e profissionais que responderam o questionário do estudo de caso, que participaram das entrevistas, que atenderam minhas ligações e responderam meus e-mails. Obrigada pela troca de informações. Sem a colaboração de cada um vocês, essa pesquisa não teria alcançado os resultados apresentados. 


\title{
CONSÓRCIOS PÚBLICOS NA GESTÃO DE RESÍDUOS SÓLIDOS URBANOS NO BRASIL
}

\begin{abstract}
Resumo
O presente trabalho discute a Política Nacional de Resíduos Sólidos (PNRS) e um dos seus instrumentos, os Consórcios Públicos, por meio de estudo de caso. Avalia-se as consequências da priorização e do incentivo ao acesso a recursos governamentais oferecidos pela PNRS aos municípios para formação de Consórcios Públicos para a gestão regionalizada da prestação de serviços de Resíduos Sólidos Urbanos. O estudo levanta e avalia as fontes de recursos governamentais que possuem linhas de financiamento para o setor de Resíduos Sólidos Urbanos e identifica as características dos Consórcios Públicos para a gestão de resíduos sólidos urbanos no Brasil por meio de um estudo de caso com 29 Consórcios Públicos das regiões Nordeste, Sudeste e Sul. Por meio do levantamento das informações e a coleta de dados empíricos revela desafios que não estão sendo avaliados e que impactam tanto a formação dos Consórcios quanto a Gestão de Resíduos Sólidos Urbanos no país.
\end{abstract}

\section{Palavras-chaves: Política Nacional de Resíduos Sólidos; Gestão de Resíduos Sólidos Urbanos; Consórcios Públicos.}




\title{
PUBLIC CONSORTIA FOR SOLID WASTE MANAGEMENT IN BRAZIL
}

\begin{abstract}
This paper discusses the National Policy for Solid Waste and one of its instruments, the Public Consortia, through a case study. Evaluates the consequences of prioritizing and promoting the access to government resources offered by the National Policy for Solid Waste to municipalities to stablish the Public Consortia for regionalized management of services urban solid waste management services. This study raises and evaluates the government resources that have credit lines for the urban solid waste management sector and identifies the characteristics of Public Consortia for urban solid waste management in Brazil through a case study of 29 Public Consortia in the Northeast, Southeast and South regions. Through gathering of information and empirical data collection reveals challenges that are not being addressed and that impact in both, the formation of Public Consortia, as well as the urban solid waste management in the country.
\end{abstract}

Keywords: National Policy for Solid Waste; urban solid waste management; Public Consortia. 


\section{LISTA DE ABREVIATURAS E SIGLAS}

AGENERSA

BID

BNDES

CEPAM

CONAMA

EA

FNDCT

FNMA

FNMC

FUNASA

GRSU

IBGE

ICMS

IDHM

IPEA

LCP

LSB

MCTI

MDL

MMA

OGU

ONGs

PEGIRS

PEV

PGIRS
Agência Reguladora de Energia e Saneamento Básico do Estado do Rio de Janeiro

Banco Interamericano de Desenvolvimento

Banco Nacional de Desenvolvimento Econômico e Social

Centro de Estudos e Pesquisas de Administração Municipal

Conselho Nacional do Meio Ambiente

Educação Ambiental

Fundo Nacional de Desenvolvimento Científico e Tecnológico

Fundo Nacional do Meio Ambiente

Fundo Nacional sobre Mudança do Clima

Fundação Nacional da Saúde

Gestão de Resíduos Sólidos Urbanos

Instituto Brasileiro de Geografia e Estatística

Imposto sobre Circulação de Mercadorias e Serviços

Índice de Desenvolvimento Humano Municipal

Instituto de Pesquisa Econômica Aplicada

Lei de Consórcios Públicos

Lei de Saneamento Básico

Ministério da Ciência, Tecnologia e Inovação

Mecanismo de Desenvolvimento Limpo

Ministério do Meio Ambiente

Orçamento Geral da União

Organizações Não Governamentais

Plano Estadual de Gestão Integrada de Resíduos Sólidos

Pontos de Entrega Voluntária

Planos de Gestão Integrada de Resíduos Sólidos 
PIGRS

PPG7

PMGIRS

PNMA

PNMC

PNUD

PNRS

PSB

RCE

RSU

SAMAE

SIC

SICONV

SNIS

TCU

UNEP
Plano Intermunicipal de Gestão Integrada de Resíduos Sólidos Programa Piloto para Proteção das Florestas Tropicais Plano Municipal de Gestão Integrada de Resíduos Sólidos Política Nacional do Meio Ambiente Política Nacional sobre Mudança do Clima Programa das Nações Unidas para o Desenvolvimento Política Nacional de Resíduos Sólidos

Plano de Saneamento Básico

Reduções Certificadas de Emissões

Resíduos Sólidos Urbanos

Serviço Autônomo Municipal de Água e Esgoto

Serviço de Informação ao Cidadão

Sistema de Convênios do Governo Federal

Sistema Nacional de Informações sobre Saneamento

Tribunal de Contas da União

United Nations Environment Programme 


\section{LISTA DE FIGURAS}

Figura 1 - Faixa de Desenvolvimento Humano Municipal .80

\section{LISTA DE QUADROS}

Quadro 1 - Aplicação dos Instrumentos de Políticas Públicas na GRSU ...........................22

Quadro 2 - Etapas de políticas públicas com base em Cuadrado Roura ............................25

Quadro 3 - Critérios de avaliação aplicados às políticas públicas......................................28

Quadro 4 - Etapas para formação de Consórcios Públicos de acordo com a Lei de

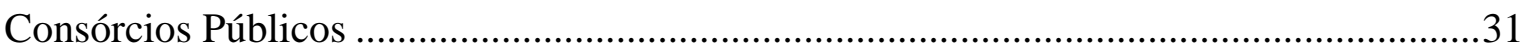

Quadro 5 - Tipos de Prestação de Serviços Públicos de RSU pelos Consórcios Públicos..32

Quadro 6 - Formas de obtenção de receitas pelos Consórcios Públicos............................ 33

Quadro 7 - Tipos de cobranças e incentivos fiscais e financeiros pela prestação dos

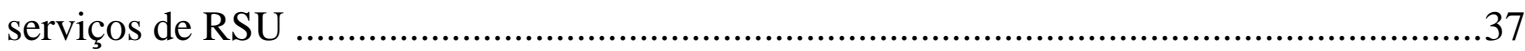

Quadro 8 - Métodos empregados para obtenção de dados dos Fundos e Programa

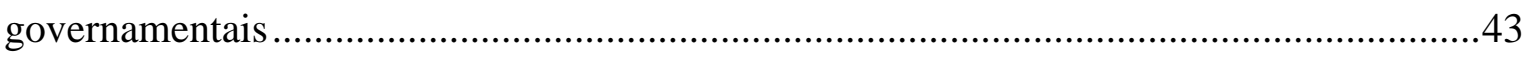

Quadro 9 - Considerações sobre os Fundos e Programa governamentais pesquisados ......55

Quadro 10 - Levantamento dos Consórcios Públicos para GRSU no Brasil........................58

Quadro 11 - Lista dos Consórcios Públicos participantes do estudo de caso......................62

Quadro 12 - Aplicação desejável e resultados observados das etapas de Primeira Fase dos

29 Consórcios

Quadro 13 - Aplicação desejável e resultados observados das etapas de Segunda Fase dos

29 Consórcios .72

Quadro 14 - Finalidade dos recursos recebidos por 22 Consórcios .76

Quadro 15 - Critérios de Avaliação de Políticas Públicas: proposição teórica para

Consórcios Públicos para GRSU 83

\section{LISTA DE GRÁFICOS}

Gráfico 1 - Distribuição quantitativa anual dos projetos municipais relacionados à GRSU e os recursos do FNMA e de contrapartida municipal 45

Gráfico 2 - Relação quantitativa de convênios do FNMA com prefeituras entre 1990 - 2012 para gestão de resíduos sólidos por faixa populacional .46 Gráfico 3 - Recursos do FNMA por projeto municipais relacionados à GRSU entre 1990 
Gráfico 4 - Distribuição por faixa populacional dos municípios com PGIRS e com PSB que contemple o serviço de limpeza urbana e manejo de resíduos sólidos

Gráfico 5 - Quantidade de projetos da Funasa com municípios por região geográfica no período de 2009 a 2013

Gráfico 6 - Classe de tamanho dos municípios integrantes dos 29 Consórcios Públicos analisados por região

Gráfico 7 - Objetivos relacionados pelos 29 Consórcios Públicos pesquisados .65

Gráfico 8 - Etapas da Primeira Fase para a formação dos 29 Consórcios Públicos........... 70

Gráfico 9- Etapas da Segunda Fase para a formação dos 29 Consórcios ..............................73

Gráfico 10 - Responsabilidade da execução das atividades de GRSU dos 29 Consórcios pesquisados .74

Gráfico 11 - Acesso a recursos (resposta de 12 Consórcios) .75

Gráfico 12 - Desafios encontrados pelos Consórcios para a manutenção dos serviços previstos no contrato do Consórcio Público . .77

Gráfico 13 - Distribuição da população total e média dos 27 Consórcios Públicos.............78

Gráfico 14 - PIB per capita médio dos 29 Consórcios Públicos - dados 2010. .79

Gráfico 15 - Índice de Desenvolvimento Humano Municipal (IDHM) médio 2010 dos 29

Consórcios Públicos

\section{LISTA DE TABELAS}

Tabela 1 - Incentivos à formação dos 29 Consórcios Públicos pesquisados pelo total da amostra, por tipo e por região geográfica .

\section{LISTA DE APÊNDICES}

Apêndice A - Questionário aplicado aos Fundos FNMA, FNDCT, Fundo Clima e Funasa

Apêndice B - Tabela elaborada com base no Relatório de Convênios 1990-2013 dos projetos do FNMA para resíduos sólidos

Apêndice C - Questionário enviado aos Consórcios Públicos para GRSU no Brasil.........116

Apêndice D - Contatos dos Consórcios Públicos participantes do estudo de caso.

Apêndice E - Dados sobre população, IDHM e PIB dos 29 Consórcios Públicos analisados 


\section{SUMÁRIO}

INTRODUÇÃO ..........................................................................................................12

1. CAPÍTULO 1 - Políticas Públicas para a gestão de resíduos sólidos urbanos.........16

1.1 Falhas de mercado na gestão de resíduos sólidos urbanos: externalidades e

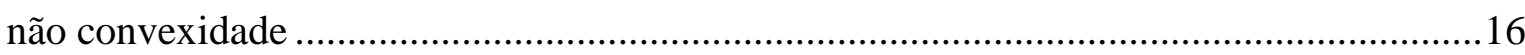

1.2 Instrumentos de políticas públicas na gestão de resíduos sólidos urbanos ....................21

1.3 Falhas de Governo na gestão de resíduos sólidos urbanos .............................................24

2. CAPÍTULO 2 - Consórcios Públicos para a gestão de resíduos sólidos urbanos....29

2.1 Conceito, objetivos e etapas para a formulação de Consórcios Públicos........................29

2.2 Atividades dos Consórcios Públicos: regulação, fiscalização e prestação de

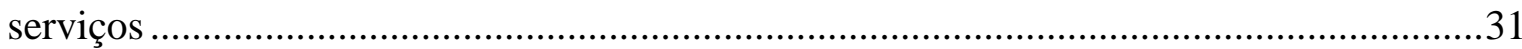

2.3 Formas de obtenção de receita para a instalação e manutenção das atividades .............33

3. CAPÍTULO 3 - Fontes de financiamento governamentais para Consórcios Públicos para gestão de resíduos sólidos urbanos no Brasil .............................................................42

3.1 Métodos e Procedimentos...........................................................................................42

3.2 Análises das informações dos Fundos e Programa governamentais pesquisados ..........44

3.2.1 Fundo Nacional de Meio Ambiente - FNMA …………………………………….....4

3.2.2 Fundo Nacional de Desenvolvimento Científico e Tecnológico - FNDCT.................48

3.2.3 Fundo Nacional sobre Mudança do Clima - FNMC ...................................................49

3.2.4 Programa para o manejo de resíduos sólidos da Fundação Nacional da

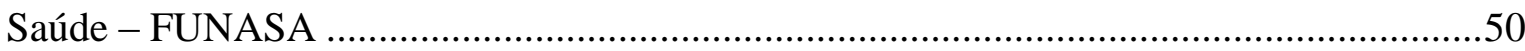

3.2.5 Considerações sobre os Fundos e Programa pesquisados ............................................53

4. CAPÍTUlO 4 - Consórcios Públicos na prática: Estudo de Caso com 29

Consórcios Públicos para a gestão de resíduos sólidos urbanos no Brasil .....................57

4.1. Métodos e Procedimentos..........................................................................................5

4.2. Análise das respostas dos 29 Consórcios Públicos para gestão de resíduos

Sólidos

4.3. Considerações sobre os resultados do estudo de caso com 29 Consórcios Públicos

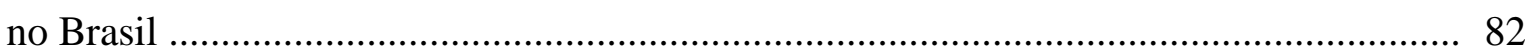

CONSIDERAÇÕES FINAIS...............................................................................................91

REFERÊNCIAS BIBLIOGRÁFICAS ......................................................................96

APÊNDICES .................................................................................................................103 


\section{INTRODUÇÃO}

Os municípios são encarregados, por lei, da provisão de serviço público de limpeza urbana e gestão dos resíduos sólidos no Brasil. Existem 5.570 municípios no país; aproximadamente $90 \%$ possuem população inferior a 50.000 habitantes (IBGE, 2014a). A Pesquisa Nacional de Saneamento Básico de 2008 (IBGE, 2010a) aponta que pouco mais de $30 \%$ desses municípios possuem uma destinação final adequada para os resíduos coletados e que $73 \%$ dos municípios com mais de 500 mil habitantes possuem destinação correta.

Nos últimos anos, normas diversas e a Política Nacional de Resíduos Sólidos ${ }^{1}$ - PNRS, têm fornecido um arcabouço legal para o setor de gestão de resíduos sólidos. A imposição de prazos para o fechamento de lixões e a implementação da disposição correta dos resíduos, prevendo tratamento, reciclagem, compostagem, recuperação de gás nos aterros, planejamento e iniciativas de recuperação de custos - pressionam os governos de todos os níveis, principalmente os municipais, a cumprir a nova Lei. No entanto, municípios, particularmente os pequenos, apresentam dificuldades - falta de recursos, planejamento e capacidade técnica para a gestão de resíduos sólidos urbanos.

Nesse contexto, os Consórcios Públicos para gestão de resíduos sólidos são indicados e priorizados no acesso a recursos pela PNRS, o que é justificado na norma por ganhos de escala, o que levaria na teoria à eficiência da prestação dos serviços de resíduos sólidos urbanos (RSU).

A PNRS representa um marco na normatização para a gestão de resíduos sólidos urbanos (GRSU) no Brasil. As políticas de GRSU devem estar preocupadas com a saúde humana e o meio ambiente. No entanto, políticas podem falhar ao tentar resolver questões sobre o que mudar ou como mudar o que já é feito para melhorar o bem-estar dos indivíduos ou sobre alternativas para se fazer o que é feito, mas utilizando menos recursos (PORTER, 2002). Nesse sentido, o presente trabalho visa discutir a PNRS e um dos seus instrumentos, os Consórcios Públicos, por meio de estudo de caso.

A primeira pergunta que impulsionou esta dissertação foi averiguar se a priorização e o incentivo ao acesso a recursos governamentais oferecidos pela PNRS aos municípios para formação de Consórcios Públicos para a gestão regionalizada da prestação de serviços de RSU conduzia a uma GRSU eficiente.

\footnotetext{
${ }^{1}$ Lei n ${ }^{\circ} 12.305$ de Agosto de 2010 e Decreto n ${ }^{\circ} 7.404$ de Dezembro de 2010.
} 
Outras perguntas complementares também surgiram em relação aos fatores econômicos, sociais e territoriais que influenciam na eficiência de uma gestão compartilhada de resíduos sólidos e que seriam determinantes no incentivo e priorização de acesso a recursos pela Lei. Para entender um instrumento determinado por uma política é necessário entender suas características e o que ela acarreta em termos de eficácia, eficiência e equidade. No entanto, ao se iniciar a pesquisa, constatou-se que não havia informações disponíveis sobre as principais características e problemas enfrentados pelos Consórcios Públicos para GRSU no país.

A lacuna informacional identificada nos levou à necessidade de ampliação da finalidade do trabalho, corroborando a visão de Ethridge (1995) ao expor que os dados e o processo de coleta de dados podem afetar como se percebe o problema e como se toma consciência dele. Realizou-se então um levantamento de dados sobre as fontes de financiamento para fins de GRSU, uma vez que a falta de recursos municipais é a primeira justificativa para o incentivo aos Consórcios. Buscou-se identificar os Consórcios Públicos para GRSU existentes no Brasil e também realizar um estudo de caso com 29 Consórcios Públicos, levantando-se, por meio das respostas obtidas, as principais características e os problemas enfrentados por este instrumento da PNRS.

Com o levantamento das informações e a coleta de dados empíricos, foi possível revelar problemas que de outra forma passariam despercebidos, como a identificação de questões primárias na gestão de resíduos sólidos que interferem no incentivo a soluções consorciadas.

Ao invés de apontar quais fatores mais influenciam a eficiência dos Consórcios, o trabalho expõe quais deles estão sendo levados em consideração na sua formação e as consequências para sua eficiência. Além disso, apresenta a relevância dos processos de avaliação e faz uma proposição de como e o que avaliar em gestão de RSU por meio de Consórcios Públicos a partir dos resultados obtidos.

Para a realização dessa dissertação, buscou-se primeiramente a fundamentação teórica baseada em uma revisão da literatura de políticas públicas ambientais com ênfase em resíduos sólidos urbanos e Consórcios Públicos no Brasil. Na etapa seguinte, para realização de uma análise empírica dos objetivos específicos construiu-se informações por meio de levantamento de dados e estudo de caso. 


\section{Estrutura do Texto}

O primeiro capítulo, a seguir, discute políticas públicas para gestão de resíduos sólidos urbanos. Primeiramente, trata de duas falhas de mercado relacionadas à gestão e gerenciamento de resíduos sólidos: externalidades e não convexidade. Em seguida, apresentam-se os instrumentos de políticas públicas: persuasão ou voluntários, comando e controle e econômicos aplicados à GRSU. Por fim, expõem-se algumas das falhas de governo em GRSU e alguns critérios de avaliação comumente apresentados na literatura de políticas públicas e que podem ser aplicados na avaliação da implementação de Consórcios Públicos para GRSU municipais.

O segundo capítulo apresenta o conceito de Consórcios Públicos, as etapas exigidas por lei para sua consecução e as atividades que podem ser desenvolvidas nesse tipo de arranjo, com ênfase na prestação de serviços para a GRSU. O capítulo traz também as formas de obtenção de receita para a instalação e a manutenção das atividades, destacando conceitualmente algumas opções de tipos de cobrança pela prestação dos serviços de RSU e incentivos fiscais e financeiros.

O terceiro capítulo foi motivado pela determinação da PNRS de prioridade no acesso a recursos financeiros aos Consórcios Públicos (BRASIL, Art. 45, 2010a). O capítulo apresenta e discute fontes de recursos governamentais para esse fim. Foram identificados e avaliados Fundos e Programas que possuem linhas de financiamento para o setor de RSU. Primeiramente, apresentaram-se os métodos e procedimentos do levantamento das informações. Em seguida, as informações específicas dos Fundos contidos na PNRS, a saber, o Fundo Nacional do Meio Ambiente - FNMA e o Fundo Nacional de Desenvolvimento Científico e Tecnológico - FNDCT (BRASIL, Art. 8, X, 2010a) são apresentadas. Além disso, discute-se também o Fundo Nacional sobre Mudança do Clima - FNMC, que possui financiamento para projetos de mitigação de gases em aterros sanitários, e o Programa de Manejo de Resíduos Sólidos da Fundação Nacional da Saúde - FUNASA, que foca em linhas de financiamento para municípios de até 50 mil habitantes para projetos em todas as fases do gerenciamento de RSU. Ao final, faz-se uma análise dos resultados obtidos com a pesquisa dos Fundos e Programa tratados com as questões teóricas abordadas nos capítulos anteriores.

O quarto capítulo se propôs a identificar os Consórcios Públicos para GRSU existentes no Brasil e apresentar as características, finalidades e especificidades de 29 Consórcios Públicos das regiões Nordeste, Sudeste e Sul que compõem assim um estudo de caso. Apresentaram-se os métodos e procedimentos e em seguida a análise das respostas obtidas. Por fim, faz-se uma 
análise dos resultados obtidos das respostas dos 29 Consórcios Públicos e os critérios de avaliação - equidade, eficiência, eficácia, incentivo ao esforço máximo, custo administrativo e geração de receita, aceitação política e permanência - apresentando uma proposta do que deve ser considerado em cada critério ao se avaliar a GRSU por Consórcios Públicos.

E por fim, apresentam-se as considerações finais e análise dos resultados obtidos, apresentando também recomendações e sugestões para trabalhos futuros. 


\section{CAPÍTULO 1: POLÍTICAS PÚBLICAS PARA GESTÃo DE RESÍDUOS SÓLIDOS URBANOS}

\subsection{Falhas de mercado na gestão de resíduos sólidos urbanos: externalidades e não convexidade}

A coleta, o tratamento e a correta disposição de resíduos sólidos urbanos (RSU) configuram uma demanda social por um serviço público por propiciar ganhos de bem-estar coletivo. Sua ocorrência gera benefícios para todos, inclusive para aqueles que para ela não colaboram. Os governos municipais têm a responsabilidade sobre o serviço público de limpeza urbana e de manejo de $\mathrm{RSU}^{2}$, os quais constituem os resíduos domiciliares e os de limpeza de logradouros e varrição de vias públicas (BRASIL, 2007b). Os resíduos provenientes dos serviços de saúde, industriais, construção civil, atividades agropecuárias, de mineração e os perigosos e radioativos são de responsabilidade dos seus geradores e, por isso, não são foco do presente trabalho.

Na GRSU, a mudança de comportamento de indivíduos e empresas está ligada à intervenção governamental, uma vez que os serviços de limpeza pública, coleta e disposição dos RSU são de responsabilidade municipal. Neste contexto, falhas de mercado são geralmente usadas para apoiar a intervenção governamental em mercados.

Diversos são os tipos de falhas de mercado: bens públicos, externalidades, mercados incompletos, informações assimétricas, comportamento não competitivo e não convexidade (DASGUPTA e MÄLER, 2004; PERMAN et al., 1999; PINDYCK e RUBINFELD, 2004). Para o presente estudo dos RSU com foco em responsabilidades compartilhadas municipais, o enfoque serão as externalidades e a não convexidade.

Externalidades ocorrem quando as decisões ou ações de produção ou consumo de um agente afetam a utilidade ou possibilidade de produção de outro agente de maneira não intencional, e quando não há nenhuma compensação recebida ou paga pelo produtor da externalidade para a parte afetada (MUELLER, 2012; PERMAN et al., 1999). O efeito da externalidade não se reflete via preço de mercado, mas sim via seu impacto sobre a utilidade ou a produção de uma terceira parte.

Por conseguinte, na presença de externalidades, preços de mercado não refletem o total dos custos sociais ou dos benefícios sociais. Quando o custo social é maior que o custo privado constatam-se externalidades negativas; agentes econômicos não incorporam os custos

\footnotetext{
${ }^{2} \mathrm{O}$ artigo 30, inciso V, da Constituição Federal (BRASIL, 1988) determina que os municípios possuem a responsabilidade de organizar e oferecer, diretamente ou sob regime de concessão ou permissão, os serviços públicos de interesse local.
} 
totais de seus atos e acabam praticando-os sem restrição. Quando o benefício social é maior que o privado, detectam-se externalidades positivas; nesse caso, os agentes não incorporam em seus custos os benefícios totais de suas ações (ANDRADE, 2005).

A população urbana, em geral, não está apta a avaliar os custos da disposição de RSU, pois geralmente não vivencia os danos causados pela disposição inadequada dos resíduos, que normalmente ocorrem distante dos aglomerados urbanos, devido ao custo da terra, logística e escassez de espaço. Com isso, pode-se dizer que os indivíduos que sofrem primeiramente ou mais diretamente os danos ambientais e sociais advindos dos resíduos sólidos são as comunidades vizinhas de lixões e aterros.

Alguns impactos que geram externalidades negativas são: mau cheiro, contaminação de águas subterrâneas, transmissão de doenças, aspectos cênicos e redução no valor da terra. Nesse sentido, Martinez e Bowen (2012) e Wagner (2011) levantam a relevância da compensação das comunidades locais próximas a aterros sanitários ou lixões por meio da inclusão do custo de oportunidade das terras das comunidades afetadas nos instrumentos de política pública.

Uma das características dos impactos ambientais, sociais e econômicos da geração dos resíduos sólidos é que eles não se restringem ao local da sua geração, podendo transferir riscos ambientais no tempo e no espaço (CALDERONI, 2003) e ainda para futuras gerações (BITHAS, 2011). Por isso, a poluição gerada por aterros sanitários é considerada de estoque. O despejo de resíduos sólidos e a eliminação de efluentes não tratados ou com disposição final inadequada, podem exceder a capacidade de assimilação do ecossistema, prejudicar a qualidade da água e a saúde humana, causando danos ambientais em âmbito local, regional e global (MUELLER, 2012; STERNER e CORIA, 2012).

Além disso, os municípios priorizam os gastos com a coleta e transporte, por questões de saúde pública. Dados da Abrelpe (2012) constataram um índice de 90,17\% de cobertura da coleta de RSU no Brasil versus 39,8\% dos municípios que destinam corretamente os RSU coletados a aterros sanitários. Os outros $60,2 \%$ vão para aterros controlados ou lixões. Isso demostra que a elevada taxa de coleta oculta as externalidades causadas pela destinação incorreta de RSU. Com isso, os custos sociais são absorvidos direta ou indiretamente por toda a sociedade.

Externalidades ambientais são parte inevitável dos processos econômicos. No entanto, a distinção das externalidades é essencial para definir o instrumento que melhor se ajusta a um específico problema ambiental, com suas características e limitações (MORENO-SÁNCHEZ e MALDONADO, 2006). 
As externalidades negativas ambientais da falta de planejamento e monitoramento da disposição incorreta de resíduos sólidos, como a infiltração dos lixiviados nos lençóis freáticos e a transmissão de doenças ocasionadas pelos lixões, ocasionam um progressivo impacto econômico de difícil mensuração. Os danos, muitas vezes, estão associados a outras externalidades, dificultando a identificação direta do local da fonte poluidora. Uma alternativa para internalizar as externalidades advindas dos resíduos sólidos e mensurar os impactos econômicos decorrentes seria dimensionar os problemas de saúde causados por água contaminada, por contaminação do solo e ar. Isso significa avaliar o custo de importar água, de consultas médicas, de dias não trabalhados por problemas de saúde, todos eles consequências do não tratamento dos resíduos.

Contrapondo-se a esta visão da economia neoclássica de estimativa das externalidades em termos monetários, Bithas (2011), numa visão da economia ecológica, considera parcial a internalização das externalidades ambientais pelo fato dos impactos serem valorados em certo intervalo de tempo e espaço. Para o autor, as externalidades afetam o bem-estar de indivíduos que pertencem a três grupos: os poluidores e os que sofrem os danos ambientais de um mesmo sistema econômico; os indivíduos das futuras gerações; e os indivíduos localizados fora do sistema institucional onde são criadas as externalidades. Segundo o autor, as externalidades só podem ser valoradas para o grupo de um mesmo sistema econômico, que sofre e que causa os danos ambientais. Os interesses das futuras gerações e dos indivíduos de outras localidades fora do sistema econômico valorado não conseguem ser refletidos em estimativas monetárias das externalidades ambientais.

Os questionamentos da economia ecológica sobre a internalização das externalidades são pertinentes e devem ser levados em consideração na implementação de políticas públicas ambientais. No caso da GRSU, a consideração dos impactos no tempo e no espaço é relevante para a resiliência dos sistemas ambientais e para a consequente escolha dos instrumentos a serem aplicados. À vista disso, mostra-se que as abordagens da economia neoclássica e ecológica não são dissociadas, mas se apresentam juntas; os questionamentos da segunda podem interferir na melhor aplicação dos instrumentos da primeira.

A questão social encontra-se enraizada no setor de resíduos sólidos no Brasil, característica encontrada em muitos países em desenvolvimento. Parcela da população pobre tem como alternativa a coleta de resíduos para reciclagem como única fonte de renda, além de existir a formalização de cooperativas de catadores de materiais recicláveis que já têm um papel determinado na hierarquia do gerenciamento de resíduos nestes países (CALDERONI, 2003; Instituto de Pesquisa Econômica Aplicada (IPEA), 2010; MARTINEZ e BOWEN, 
2012; STERNER e CORIA, 2012). Para Moreno-Sánchez e Maldonado (2006), os catadores geram externalidades positivas para a sociedade, pois, por meio da coleta de materiais recicláveis, eles aumentam a vida útil dos aterros e a disponibilidade de recursos naturais. À vista disso, a lei que institui a Política Nacional de Resíduos Sólidos - PNRS (BRASIL, Lei 12.305, 2010a e Decreto 7.404, 2010b) - proporcionou o reconhecimento do setor ao estabelecer a inclusão dos catadores de materiais reutilizáveis e recicláveis nos Planos de Gestão de Resíduos Sólidos federais, estaduais e municipais e definir a sua participação no processo.

As externalidades negativas estão interligadas a outra falha de mercado - a não convexidade. O acúmulo de poluição ocasionado por resíduos e rejeitos no meio ambiente possui consequências no longo prazo e pode causar danos irreversíveis ao meio ambiente. Quando o limite dos ecossistemas é ultrapassado pelo acúmulo de poluição de resíduos podese causar desestabilização no sistema (MUELLER, 2012). A resiliência dos ecossistemas possui vários estágios de equilíbrio e, se esta perturbação for suficientemente forte, o sistema pode não voltar ao seu estado original. Os danos da poluição e destruição de recursos naturais não serão automaticamente revertidos e medidas precisam ser tomadas antes que o sistema se desestabilize.

Conjuntos convexos surgem da possibilidade de combinações entre bens e serviços ambientais. Quando as combinações constituem conjuntos indivisíveis são não convexas (DASGUPTA e MÄLER, 2004). A ausência das combinações ou sua indivisibilidade tornam a realização da otimização inatingível. No contexto da gestão e gerenciamento de resíduos sólidos municipais, tal situação explicaria o fato de um projeto de coleta, transporte e tratamento de um tamanho ou abrangência $\mathrm{X}$ ser viável, mas um projeto da metade do tamanho de $\mathrm{X}$ possuir custos bem mais elevados e ser ineficiente e, com isso, inviável se não houver intervenção governamental (DASGUPTA e MÄLER, 2004). A mesma ideia pode ser aplicada no caso de obras de infraestrutura, saneamento ambiental e esgoto, recuperação de solo e financiamento de pesquisas.

A região pode precisar desses bens e serviços públicos, mas encontrar os serviços disponíveis ineficientes. No entanto, esses serviços precisam ser fornecidos à população, sendo responsabilidade dos tomadores de decisão analisarem medidas eficientes para cada região. Para Sterner e Coria (2012), a ausência de soluções intermediárias implica escolhas restritas, e a presença de não convexidade poderia ser criada por meio de retornos crescentes de escala. 
Mendes (2013), ao analisar os custos médios de bens e serviços públicos municipais, constatou que esses custos unitários sociais médios estariam relacionados ao tamanho dos municípios e aglomeração populacional, ou seja, eles seriam maiores em municípios muito pequenos pela ausência de economias de escala. Por outro lado, esses custos teriam seus valores inferiores em cidades consideradas médias, com a existência de economias de escala ocasionada pela presença de mercados produtores e consumidores e de infraestrutura, o que atrai investimentos e diminui riscos e custos, levando a uma maior eficiência de provisão de bens e serviços públicos locais. Em municípios muito pequenos, os custos de provisão de bens e serviço públicos locais são maiores devido a uma baixa aglomeração populacional e um alto custo fixo inicial. Já em municípios muito grandes, custos variáveis crescentes resultariam de supercongestionamento.

Dessa maneira, para garantir a oferta dos bens e serviços públicos em municípios pequenos, a junção regional de pequenos municípios seria capaz de reduzir os custos unitários sociais para a prestação mais eficiente de bens e serviços públicos compartilhados (MENDES, 2013), com a participação governamental, pois a presença de não convexidade em tais atividades tornaria inviável a oferta por empresas privadas, que não estão dispostas a arcar com os custos de longo prazo. Com isso, atividades para GRSU como a construção e operação de um aterro sanitário podem ser desenvolvidas também por meio de parcerias público-privadas, concessões ou Consórcios Púbicos, sempre com a participação governamental.

Um dos instrumentos incentivados pela $\mathrm{PNRS}^{3}$ é a prestação regionalizada dos serviços de GRSU por meio da formação de Consórcios Públicos, os quais têm prioridade no acesso a recursos governamentais. Os Consórcios têm o objetivo de tentar reduzir os custos privados do manejo de RSU distribuindo os custos com mais de um município para melhorar os serviços prestados, dispor de forma correta os RSU, melhorar a prestação dos serviços, reduzir custos de investimentos, aumentar cooperação técnica, incluir os catadores de materiais recicláveis no processo de coleta seletiva e mitigar os danos ambientais (NASCIMENTO NETO e MOREIRA, 2012; MORAES, 2012, IPEA, 2012). Mendes (2013) discorre sobre a relevância dos arranjos federativos como um instrumento para redução do custo social e como forma de prover as demandas sociais de bens e serviços públicos. Nesse sentido, os Consórcios Públicos apresentam-se como solução pela PNRS principalmente para

\footnotetext{
${ }^{3}$ A Lei de Saneamento Básico (LSB) também incentiva a formação de Consórcios Públicos (BRASIL, 11.445, 2007b).
} 
pequenos municípios que enfrentam diversas dificuldades para GRSU como a falta de recursos financeiros, infraestrutura e capacidade técnica.

\subsection{Instrumentos de políticas públicas na gestão de resíduos sólidos urbanos}

As políticas públicas de GRSU preocupam-se em internalizar as externalidades ambientais negativas com o intuito de mitigar os impactos na saúde humana e meio ambiente, podendo atuar por meio de instrumentos de persuasão ou voluntários, instrumentos de comando e controle e instrumentos econômicos. O Quadro 1 apresenta a definição desses instrumentos e aponta suas aplicações à GRSU, analisando o seu uso pela PNRS e mostrando a importância na escolha dos instrumentos para as políticas públicas de GRSU.

Para definir qual instrumento seria mais adequado para resolver determinado problema ambiental, a United Nations Environment Programme - $\mathrm{UNEP}^{4}$ (2009) recomenda que os tomadores de decisão avaliem primeiro a natureza e a extensão do problema. $\mathrm{O}$ documento apresenta algumas questões que precisam ser levadas em consideração: mensurar os impactos na saúde humana e no meio ambiente em longo prazo; avaliar se o problema ambiental é o uso excessivo de um recurso natural ou a emissão de poluentes; determinar se os danos são irreversíveis; identificar se o alcance geográfico dos danos é local, regional ou global; avaliar a extensão da quantidade de pessoas afetadas e o impacto em seu bem-estar; e identificar as partes interessadas na redução dos danos causados pelo problema ambiental. Esses questionamentos auxiliarão os tomadores de decisão na escolha do instrumento ou combinação de instrumentos mais apropriados para cada caso. Isso vai depender da adequação conforme os objetivos da política proposta e do impacto dos danos ambientais em conjunto com o contexto político, econômico e social da localidade a ser implementado.

A fraca regulamentação da legislação em GRSU é apontada como uma barreira a ser enfrentada nos primeiros passos do planejamento de políticas públicas para a GRSU, principalmente em países em desenvolvimento (EZEAH e ROBERTS, 2012). Nos lugares onde não há uma política de gestão de resíduos, o primeiro passo é a implementação de regulamentação direta. Dessa maneira, apesar de algumas limitações, como as listadas no Quadro 1 e outras que serão tratadas ao longo do trabalho, a aprovação da PNRS demarca uma nova etapa nas políticas públicas de GRSU no Brasil, pois normatiza processos e deveres a serem cumpridos por indivíduos, empresas e governos em âmbito nacional.

\footnotetext{
${ }^{4}$ Programa das Nações Unidas para o Meio Ambiente - PNUMA (em português).
} 
Quadro 1 - Aplicação dos Instrumentos de Políticas Públicas na GRSU

\begin{tabular}{|c|c|c|}
\hline $\begin{array}{l}\text { Instrumentos de } \\
\text { Políticas Públicas }\end{array}$ & Definição & Aplicação para a gestão de resíduos sólidos urbanos \\
\hline $\begin{array}{l}\text { Persuasão ou } \\
\text { voluntários }\end{array}$ & $\begin{array}{l}\text { Incentivam a mudança de } \\
\text { comportamento de } \\
\text { indivíduos e empresas para a } \\
\text { proteção do meio ambiente. } \\
\text { Embora a intervenção } \\
\text { governamental esteja } \\
\text { essencialmente presente nas } \\
\text { políticas públicas, não é uma } \\
\text { atividade exclusiva do } \\
\text { Estado. }\end{array}$ & $\begin{array}{l}\text { Exemplos que podem ser aplicados à GRSU são a educação ambiental (EA) e a difusão de informaçães } \\
\text { (NOGUEIRA e PEREIRA, 1999). A EA é considerada como complementar aos instrumentos aplicados na } \\
\text { GRSU, pois o envolvimento da população nos processos e aceitação política da aplicação de um dado } \\
\text { instrumento são fundamentais para sua continuidade. Além disso, a EA é um dos instrumentos da PNRS e um } \\
\text { dos requisitos dos Planos Nacionais, Estaduais e Municipais de Gestão de Resíduos Sólidos. } \\
\text { Eigenheer (2008) chama a atenção para a complexidade e falta de informações usuais quando do emprego da EA } \\
\text { na GRSU. Para o autor, é necessário conhecer as dificuldades do setor, a realidade social e econômica municipal, } \\
\text { as necessidades cotidianas e o funcionamento do sistema de limpeza urbano para identificar se as ações } \\
\text { propostas em EA condizem com as caraterísticas locais e se são executáveis. Adicionalmente, segundo o autor } \\
\text { uma gestão municipal de resíduos deveria contar com atividades de EA que exponham clara e diretamente os } \\
\text { danos ambientais, sociais e econômicos causados pelas ações inadequadas e como ações individuais podem se } \\
\text { transformar em benefícios para toda a sociedade. }\end{array}$ \\
\hline $\begin{array}{c}\text { Comando e } \\
\text { Controle }\end{array}$ & $\begin{array}{l}\text { Regulamentam e fiscalizam } \\
\text { por meio de leis, normas e } \\
\text { aplicação de penalidades os } \\
\text { problemas ambientais. }\end{array}$ & $\begin{array}{l}\text { O poder público visa controlar diretamente a poluição e os danos ao meio ambiente, regular o uso dos recursos } \\
\text { naturais, determinar padrões de emissões e tecnologias a serem utilizadas. O cumprimento das normas deve ser } \\
\text { assegurado por meio de penalidades ou multas estipuladas nas leis e normas (UNEP, 2009). Exemplos desse } \\
\text { instrumento são a PNRS, a LSB, várias resoluções do Conselho Nacional do Meio Ambiente (CONAMA), entre } \\
\text { outros. } \\
\text { Apesar da sua importância, os instrumentos de comando e controle apresentam certas limitações e imposições de } \\
\text { ações para a GRSU. Tomando como exemplo a PNRS, pode-se citar: } \\
\text { - Incapacidade das agências ambientais ou dos munícipios de aplicarem as leis por falta de recursos } \\
\text { financeiros, técnicos e de infraestrutura (MARGULIS, 1992), como exemplo o não cumprimento dos prazos } \\
\text { dos artigos } 54 \text { e } 55 \text { da PNRS que tratam da erradicação dos lixões em quatro anos e a elaboração dos Planos } \\
\text { de Gestão Integrada de Resíduos Sólidos (PGIRS) em dois anos a contar da publicação da lei pelos } \\
\text { municípios. Com o não cumprimento, novos prazos foram dados para elaboração dos Planos e multas serão } \\
\text { aplicadas aos municípios que ainda possuem lixões; } \\
\text { - A complexidade das leis e as exigências legais estão acima da capacidade administrativa municipal } \\
\text { (MARGULIS, 1992), proposição que pode ser observada na dificuldade dos municípios em cumprir todos } \\
\text { os aspectos da PNRS ou de aplicar as penalidades estabelecidas na Lei, ou quando o fazem, não condizem } \\
\text { ao dano ambiental da disposição inadequada (IPEA, 2012); } \\
\text { - Os instrumentos de comando e controle podem fornecer incentivos inadequados para adoção de métodos } \\
\text { para combater a poluição. Os municípios brasileiros são marcados por relevantes diferenças regionais - }\end{array}$ \\
\hline
\end{tabular}




\begin{tabular}{|c|c|c|}
\hline & & $\begin{array}{l}\text { tamanho, geografia, receita, população, cultura, capacidade técnica - o que dificulta o cumprimento de } \\
\text { regulamentações ou processos muito específicos e complexos (EIGENHEER, 2008); } \\
\text { - Dificuldade no estabelecimento de padrões de poluição ótimos, fiscalização e aplicação de penalidades } \\
\text { (Andrade, 2005), como exemplo, a grande quantidade de disposições ilegais de RSU em áreas públicas e } \\
\text { privadas. }\end{array}$ \\
\hline Econômicos & $\begin{array}{l}\text { Possuem a finalidade de } \\
\text { alcançar metas ambientais } \\
\text { via sistema de preços. }\end{array}$ & $\begin{array}{l}\text { Para GRUS seria fazer com que produtores e consumidores reduzam a geração, reutilizem, reciclem, tratem e } \\
\text { disponham corretamente os resíduos e para a aplicação de novas tecnologias. As formas utilizadas podem ser por } \\
\text { meio de subsídios, impostos e taxas (UNEP, 2009). O objetivo da taxa é penalizar e desincentivar ações } \\
\text { poluidoras com o intuito de reduzir a degradação ambiental. A inserção do imposto visa corrigir o preço do } \\
\text { mercado, ou seja, o desequilíbrio entre o custo marginal privado e social, fazendo com que o individuo ou } \\
\text { empresa arque com o custo social de suas ações (UNEP, 2009). Com isso, os custos sociais das ações de } \\
\text { indivíduos e empresas seriam incorporados à sua tomada de decisão. Os subsídios podem ser utilizados para } \\
\text { incentivar práticas que contribuem para a redução da poluição, como subsídios às empresas de reciclagem, ou } \\
\text { auxiliar poluidores a suportarem os custos de controle de poluição (ANDRADE, 2005). } \\
\text { Os instrumentos econômicos não estão livres de limitações e os requisitos administrativos desses instrumentos } \\
\text { precisam ser levados em consideração na aplicação de políticas para avaliar sua aplicabilidade (NAHMAN e } \\
\text { GODFREY, 2010). Neste sentido, o IPEA (2012) ressalta a falta de instrumentos desenhados para minimizar o } \\
\text { desperdício de recursos naturais ou a geração de resíduos. }\end{array}$ \\
\hline
\end{tabular}

Fonte: Elaboração própria, a partir de ANDRADE, 2005; BRASIL, 2010a; EIGENHEER, 2008; IPEA, 2012; MARGULIS, 1992; NAHMAN e GODFREY, 2010; NOGUEIRA e PEREIRA, 1999; UNEP, 2009. 


\subsection{Falhas de Governo na gestão de resíduos sólidos urbanos}

Quando mercados falham, políticas governamentais devem ser implementadas para superar essas falhas e promover o bem-estar da sociedade como um todo. No entanto, o governo muitas vezes não é capaz de interferir para corrigir os danos causados pelas falhas de mercado e alocar os recursos eficientemente. Esta situação de incapacidade ou limitação de agir e que interfere na aplicabilidade de políticas e instrumentos é chamada de falhas de governo (GHOSH, 2001; UNEP, 2009). Mendes (2011) complementa tal definição descrevendo as falhas de governo como situações que fazem com que as intervenções governamentais, ao invés de agir para alcançar um objetivo ou solucionar um problema, causem maiores distorções do que as que deveria resolver.

Ghosh (2001) estabelece alguns aspectos que explicariam as falhas de governo, como: a ineficiência do setor público causada pela falta de incentivos; dificuldade em se avaliar e mensurar a quantidade e qualidade dos bens e serviços públicos; dificuldade do monitoramento dos agentes públicos; e pressão de grupos de interesses ou coalizões partidárias para aprovarem projetos sem o completo estudo de custos sociais.

Os autores Ghosh (2001), Souza (2006) e UNEP (2009) listam algumas razões que podem causar as falhas de governo, como: a influência de pressões de grupos de interesses ou movimentos sociais, políticas definidas exclusivamente por aqueles que estão no poder ou coalizões governamentais, votações que não levam ao ótimo social de bem-estar da sociedade, incapacidade de superar interesses burocráticos, troca de favores entre os partidos para votações de projetos de seu interesse, incapacidade de coordenar as ações de seus Ministérios e Agências, falta de informações precisas e negligência de custos e benefícios de projetos e falta de recursos para financiar programas ambientais necessários. A seguir, tratar-se-á de algumas dessas falhas de governo tendo como base a GRSU.

\section{Falhas de Política}

As políticas públicas envolvem processos que vão além da tomada de decisão, implicam nas fases de implementação, execução e avaliação (SOUZA, 2006). As falhas de política consistem nas falhas de implementação das políticas, programas e projetos, e no desconhecimento entre as conexões entre os instrumentos e objetivos a serem desenvolvidos (GHOSH, 2001). Resume-se na distância entre reconhecer o problema e agir para resolver e na lacuna entre implementar a política e o seu resultado. 
Cuadrado Roura (1997) estabelece seis etapas no processo de tomada de decisões governamentais que se enquadrariam na tentativa de minimizar as distorções das falhas de política na GRSU sintetizados no Quadro 2.

\section{Quadro 2 - Etapas de políticas públicas com base em Cuadrado Roura}

\begin{tabular}{|l|l|}
\hline \multicolumn{1}{|c|}{ Etapas Roura } & \multicolumn{1}{c|}{ Definição } \\
\hline Reconhecimento & $\begin{array}{l}\text { Obtenção de informações estatísticas do setor de RSU - situação da coleta e disposição } \\
\text { final de resíduos, disponibilidade de dados das variáveis econômicas referentes aos } \\
\text { impactos ambientais, como o nível de poluição causada pela lixiviação de lixões, } \\
\text { contaminação de águas subterrâneas, impacto na saúde da população e transmissão de } \\
\text { doenças. Com isso, estabelecem-se modelos e previsões em curto prazo. Falta de } \\
\text { informações e dados antigos podem atrapalhar essa etapa. }\end{array}$ \\
\hline Análise & $\begin{array}{l}\text { O objetivo da etapa de análise é averiguar a necessidade de intervenção, os dados } \\
\text { estatísticos adquiridos na etapa de reconhecimento são analisados e interpretados com a } \\
\text { realização de um diagnóstico com preparação de informes de conjuntura de estudos } \\
\text { sobre ciclos e tendências. Pode-se consultar banco de dados de agências governamentais } \\
\text { ou instituições privadas e Universidades. Não deve ser realizada apenas na fase de } \\
\text { implementação, mas ser contínua em todos as fases para que novos rumos na tomada de } \\
\text { decisões possam ser tomados. }\end{array}$ \\
\hline Desenho & $\begin{array}{l}\text { Planejamento e estruturação das medidas e ações públicas a serem tomadas para } \\
\text { enfrentar os problemas detectados na análise. O próprio governo tem a tarefa de } \\
\text { desenhar as medidas, no entanto, outros organismos podem auxiliar nessa fase. }\end{array}$ \\
\hline Consultas & $\begin{array}{l}\text { Consultas às partes interessadas, grupos de interesse, partidos políticos, Ministérios, } \\
\text { Organismos Internacionais sobre a política, plano ou programa previamente desenhado } \\
\text { com o intuito de obter informações da realidade local ou problemas e necessidades que } \\
\text { podem impactar na aplicabilidade dos instrumentos. }\end{array}$ \\
\hline Discussão no & $\begin{array}{l}\text { Debate e aprovação das medidas. Dependendo da complexidade da política, pode-se } \\
\text { criar Comissões para analisar os diferentes temas. }\end{array}$ \\
\hline Congresso & $\begin{array}{l}\text { Após a tomada de decisão de aplicar certas medidas, entra-se na etapa de execução, que } \\
\text { é a implementação propriamente dita das ações e atividades da política pública. As } \\
\text { etapas de monitoramento, avaliação e divulgação estão contidas nessa etapa. }\end{array}$ \\
\hline
\end{tabular}

Fonte: Elaboração própria, a partir de Cuadrado Roura (1997).

Roura (1997) ressalta que a ordem das etapas pode ser alterada e que informações obtidas numa fase podem acrescentar informações às fases antecedentes como, por exemplo, os resultados das consultas podem revisar o desenho das medidas e a análise feita previamente. No entanto, a problemática é que nem sempre todas essas etapas são consideradas no processo de formulação e implementação de políticas públicas.

Entre o projeto de lei 203/1991 da política e a PNRS propriamente dita, foram dezenove anos de debates, criação de Comissões, audiências públicas e interferência de grupos de interesses para a sua aprovação. No longo processo da aprovação da PNRS, além da falha de política, pode-se incluir a influência de grupos de interesse. Um grupo de interesse ou pressão são indivíduos ou grupos que se unem para exercer influência sobre o governo na

\footnotetext{
${ }^{5}$ A importância de se debater as possibilidades da implementação de um instrumento para GRSU primeiro com as partes envolvidas é tratada em Calderoni (2003), Bithas (2011), Sterner e Coria (2012), Martinez e Bowen (2012), Moreno-Sánchez e Maldonado (2006) e IPEA (2010).
} 
aprovação ou desaprovação de leis de acordo com seus objetivos e interesses. Pode ser exercido por organizações empresariais de um determinado setor, sindicatos ou sociedade civil (BORSANI, 2005). A Confederação Nacional das Indústrias - CNI e o Movimento Nacional de Catadores de Materiais Recicláveis são exemplos de alguns grupos de interesse que exerceram sua influência e conseguiram impor seus interesses nas audiências e fóruns que antecederam a aprovação da Lei (MMA, 2014f).

\section{Setor e Burocracia Públicos Ineficientes}

O serviço público, por suas características de estabilidade, obediência aos regulamentos e procedimento burocráticos, nem sempre estimula os servidores públicos ao esforço de aprendizado e inovação encontrado no ambiente de competição do setor privado (MENDES, 2011). Segundo Ghosh (2001), as ineficiências na gestão de resíduos e a lacuna de conhecimento técnico por parte dos servidores também decorrem dos custos crescentes, baixa produtividade e supervisão ineficaz. Adicionalmente, a capacidade técnica dos municípios brasileiros em gestão de resíduos sólidos é baixa, se comparada à necessidade do setor.

\section{Problemas na Relação Agente-Principal}

A relação agente-principal refere-se à relação entre Ministérios e Agências de um determinado setor. As falhas ocorrem pela dificuldade de monitoramento e informações insuficientes que ambos possuem, ocasionando divergência entre os objetivos dos agentes e dos principais (MENDES, 2011). Cada um pode seguir o interesse que mais o convém, impactando nos resultados das políticas/ programas e projetos.

\section{Ausência de Transversalidade setorial}

A falta de transversalidade setorial entre as diversas agências do governo também pode ser considerada uma falha de governo. A problemática da GRSU não envolve apenas as agendas ambientais e de saneamento, mas os Ministérios da Saúde, Social e Combate à Fome, Ciência e Tecnologia, Agricultura, Cidades, Tribunais de Contas e setores econômicos. Com isso, a formulação de uma política para um determinado problema ambiental pode influenciar e são influenciadas por outras políticas e setores. 
O artigo $7^{\circ}$ da PNRS (BRASIL, 2010a) prevê a necessidade de articulação com os setores que de alguma forma estão envolvidos na questão da GRSU e o artigo $3^{\circ}$ do Decreto 7.404 (BRASIL, 2010b) estabelece o Comitê Interministerial da Política com representantes de vários órgãos governamentais. Os setores envolvidos têm o objetivo de apoiar a implementação da PNRS e debater o impacto da política nos seus próprios setores e a interferência em políticas já existentes.

Para Mendes (2011), deveria haver uma avaliação prévia sobre toda ação governamental para mensurar as possíveis falhas de governo derivadas de determinada ação. As consequências das falhas de governo podem levar ao aumento dos custos da intervenção governamental, que passam a ser maiores do que seus benefícios, em vez de resolver as falhas de mercado. Pode haver um acréscimo nos efeitos negativos de bem-estar, perda da confiança e da credibilidade quanto ao governo ser capaz de resolver as falhas de mercado (GHOSH, 2001).

Segundo UNEP (2009), os processos de avaliação de políticas precisam ser implementados desde a concepção da política, pois dessa forma é possível avaliar o progresso e efetuar modificações quando necessário. Além disso, a probabilidade de sucesso de uma política diminui quanto mais difícil for avaliá-la e fazer cumprir as medidas estipuladas.

Definir os critérios de avaliação para as diferentes políticas e identificar qual a que melhor responde a determinado problema ambiental não é tarefa fácil devido a sua complexidade e aos interesses envolvidos (NOGUEIRA e PEREIRA, 1999). O Quadro 3 tem o intuito de apresentar as definições teóricas de alguns critérios de avaliação comuns na literatura de políticas públicas que auxiliarão a análise empírica de suas aplicações na avaliação da implementação dos Consórcios Públicos para GRSU por meio do estudo de caso, objeto de interesse desta dissertação. 
Quadro 3 - Critérios de avaliação aplicados às políticas públicas

\begin{tabular}{|c|c|}
\hline $\begin{array}{c}\text { Critérios de } \\
\text { Avaliação }\end{array}$ & Definição \\
\hline Eficiência & $\begin{array}{l}\text { Analisa a política ou instrumento do ponto de vista econômico, ou seja, a análise do alcance das metas pela redução da poluição a um menor } \\
\text { custo. Para que a política seja socialmente eficiente, não deverá necessariamente ser eficiente em custos, mas equilibrar custos e benefícios, } \\
\text { ao tentar minimizar custos e alcançar um benefício maior (BAUMOL e OATES, 1979; FIELD, 1997). }\end{array}$ \\
\hline $\begin{array}{l}\text { Incentivo ao } \\
\text { esforço } \\
\text { máximo ou } \\
\text { motivação }\end{array}$ & $\begin{array}{l}\text { Visa quantificar os incentivos oferecidos que levam à superação dos objetivos estabelecidos pelas políticas públicas, levando empresas e } \\
\text { indivíduos a buscar formas e comportamento inovadores e melhoria contínua da redução do nível de degradação (FIELD, 1997). }\end{array}$ \\
\hline $\begin{array}{c}\text { Custo } \\
\text { administrativo }\end{array}$ & $\begin{array}{l}\text { Refere-se aos custos dos recursos necessários para administrar o instrumento ou implementar a política, sejam eles os custos operacionais, } \\
\text { regulatórios, de monitoramento e de fiscalização. As políticas, programas e projetos aprovados precisam de um planejamento inicial que } \\
\text { garanta o financiamento dos recursos necessários. Mesmo as previsões de instrumentos econômicos que forneçam fundos por meio de } \\
\text { tributos precisarão de um financiamento inicial para estabelecer o programa ou projeto (UNEP, 2009). }\end{array}$ \\
\hline Permanência & $\begin{array}{l}\text { Para a permanência de uma política ela precisa ser realista, as mudanças de comportamento dos agentes precisam permanecer mesmo com a } \\
\text { retirada dos seus estímulos e que isso não provoque uma regressão ao comportamento anterior (BAUMOL e OATES, 1979). }\end{array}$ \\
\hline
\end{tabular}

Fonte: Elaboração própria, a partir de BAUMOL e OATES, 1979; FIELD, 1997; OECD, 1997 apud UNEP, 2009 ; UNEP, 2009. 


\section{CAPÍTUlO 2: CONSÓRCIOS PÚBLICOS PARA A GESTÃo DE RESÍDUOS SÓLIDOS URBANOS}

\subsection{Conceito, objetivos e etapas para a formulação de Consórcios Públicos}

Conceitualmente, Consórcios Públicos baseiam-se na cooperação voluntária entre entes da Federação para atuação conjunta em assuntos de interesses comuns, conforme regulamentado pela Lei de Consórcios Públicos (LCP) (BRASIL, Lei 11.107, 2005; Decreto 6.017, 2007a). Os Consórcios Públicos estão presentes em diferentes setores, como saúde, transporte, desenvolvimento regional, turismo, saneamento, resíduos sólidos, entre outros.

Os Consórcios Públicos podem ser formados de maneira horizontal, mesma esfera de governo, entre município - município ou estado - estado; ou vertical, com entes federativos diferentes, município e estado ou município, estado e União (BRASIL, 2005). O seu território de abrangência é restrito à soma dos territórios dos entes consorciados (BRASIL, 2005).

Os objetivos do Consórcio são determinados pelos entes federativos consorciados e estão relacionados no Protocolo de Intenções, que é o contrato preliminar do Consórcio. Os Consórcios Públicos para GRSU podem atuar para desenvolver PGIRS, na prestação dos serviços de coleta regular e/ou seletiva, implantar unidades de compostagem e material reciclável, construir e operar aterros sanitários para disposição final, compartilhar instrumentos e equipamentos, realizar intercâmbio de experiências e informações, entre outros objetivos de acordo com os interesses e necessidades dos entes consorciados. Fica a critério de cada ente consorciado se associar a todos os objetivos ou apenas a uma parcela deles (BRASIL, 2007a).

Além disso, os Consórcios Públicos podem ser multifinalitários, ou seja, atender diferentes objetivos ou setores em um mesmo contrato de Consórcio Público. Neste caso, o Consórcio pode prestar qualquer tipo de serviço que seja de interesse dos municípios consorciados, em outras áreas de políticas públicas como educação, saúde, segurança e etc., como um Consórcio para GRSU que também tenha como objetivo questões de saúde e turismo ou um Consórcio de Recursos Hídricos que também inclua em seus objetivos a GRSU (AMARAL, 2014; CARNEIRO, 2014).

Segundo Schneider et al. (2013), a gestão associada de serviços públicos pode envolver tanto o planejamento conjunto de determinadas políticas, sem criar uma instância própria de execução de serviços, quanto compreender a delegação de funções de fiscalização e regulamentação de atividades realizadas pelos entes federativos consorciados. Os 
Consórcios Públicos assumem personalidade jurídica própria e, por isso, podem receber a titularidade dos serviços públicos, no que se diferenciam dos Convênios de Cooperação, onde há apenas a transferência parcial de competências de um ente da federação para outro (Monteiro, 2009 apud Nascimento Neto e Moreira, 2012).

Nesse sentido, um dos pontos tratados nos Planos Estaduais de Gestão Integrada de Resíduos Sólidos - PEGIRS - tem sido estudos de regionalização da GRSU, como por exemplo, o do estado de Pernambuco, que incluiu em seu PEGIRS (2012) um capítulo sobre isso. No caso do Plano de Pernambuco, foram estabelecidos critérios demográficos, logísticos, econômicos, ambientais, de infraestrutura física e operacional e aspectos sociais para justificar a formação de arranjos federativos consorciados. Observaram-se também questões como a distância entre os municípios, a presença de bacias hidrográficas, infraestruturas já existentes de unidades de tratamento e destinação final.

Os PEGIRS podem ser considerados instrumentos que viabilizam a identificação de arranjos regionais de acordo com as necessidades e as características locais e avaliam se eles são viáveis para aquela região e setor. De acordo com a PNRS, além dos estados, cada município deve elaborar o seu Plano Municipal de Gestão Integrada de Resíduos Sólidos PMGIRS e, quando optarem por soluções consorciadas, o Plano Intermunicipal de Gestão Integrada de Resíduos Sólidos (PIGRS) (BRASIL, 2010a).

Os Planos são ferramentas de planejamento para os municípios e Consórcios, uma vez que devem possuir informações de: diagnóstico da situação dos resíduos sólidos gerados no território, identificação de áreas favoráveis para disposição final, identificação de possibilidades de soluções consorciadas, regras de operação, programas e ações de capacitação técnica, programas e ações de participação de grupos de interesse, sistema de cálculo dos custos, formas de cobrança da prestação dos serviços, identificação de passivos ambientais e medidas saneadoras, entre outros (BRASIL, 2010a).

As etapas determinadas pelos instrumentos de comando e controle pelas quais a formação dos Consórcios Públicos deve passar estão listadas no Quadro 4. 
Quadro 4 - Etapas para formação de Consórcios Públicos de acordo com a Lei de Consórcios Públicos

\begin{tabular}{|c|c|}
\hline Etapas & Descrição \\
\hline 1) Protocolo de Intenções & $\begin{array}{l}\text { É o documento inicial e deve ser publicado na imprensa oficial. } \\
\text { Definirá a finalidade e a área de atuação do Consórcio, a estrutura } \\
\text { organizacional, a duração do mandato do representante legal - o } \\
\text { Chefe do Poder Executivo, no caso dos municípios, um dos prefeitos } \\
\text { dos municípios consorciados, e o número de votos que cada ente } \\
\text { consorciado possuirá na Assembleia Geral. A gestão associada pode } \\
\text { ser para o planejamento, regulação, fiscalização e para a prestação de } \\
\text { serviços públicos de RSU. O Consórcio pode assumir, de acordo } \\
\text { com o estabelecido no Protocolo de Intenções, todas as fases de } \\
\text { prestação do serviço ou apenas uma parte, podendo prestar os } \\
\text { serviços diretamente ou delegar. Os critérios de cálculo de cobrança } \\
\text { pelos serviços prestados devem estar descritos no Protocolo. Por sua } \\
\text { natureza voluntária, nem sempre os Entes que assinaram o Protocolo } \\
\text { de Intenções ratificarão o mesmo e se tornarão consorciados. }\end{array}$ \\
\hline $\begin{array}{l}\text { 2) Ratificação do } \\
\text { Protocolo de Intenções }\end{array}$ & $\begin{array}{l}\text { É efetuado por meio de lei, nas respectivas Casas Legislativas de } \\
\text { cada ente federativo. Pode-se prever mediante cláusula no Protocolo } \\
\text { de Intenções a quantidade mínima de ratificações para a constituição } \\
\text { do Consórcio. O Protocolo passa a ser designado Contrato de } \\
\text { Consórcio Público, e os Entes Federativos que o ratificaram passam a } \\
\text { ser chamados de consorciados. }\end{array}$ \\
\hline $\begin{array}{l}\text { 3) Convocação da } \\
\text { Assembleia Geral }\end{array}$ & $\begin{array}{l}\text { Declara a constituição do Consórcio, com a verificação das etapas } \\
\text { anteriores, e é definido o Estatuto do Consórcio Público. É pela } \\
\text { Assembleia Geral que são tomadas ou anunciadas as decisões ou } \\
\text { aprovações de alteração, inclusão ou retirada de entes consorciados. }\end{array}$ \\
\hline
\end{tabular}

Fonte: Elaboração própria, a partir de BRASIL, 2005; BRASIL, 2007a; SCHINEIDER et al., 2013.

Ressalta-se que a LCP não prevê etapas de planejamento, como estudos de viabilidade econômica, de diagnóstico do setor, de consultas às partes interessadas e outros setores envolvidos antes da formação efetiva dos Consórcios Públicos. No caso dos Consórcios Públicos para a GRSU, os PGIRS podem cumprir uma parte das etapas de planejamento.

\subsection{Atividades dos Consórcios Públicos: regulação, fiscalização e prestação de serviços}

As atividades de regulação do manejo de RSU podem ser executadas por órgão regulador criado por lei: pelo estado, por delegação dos municípios consorciados; pelo próprio Consórcio ou pelos municípios consorciados (SCHINEIDER et al., 2013; BRASIL, 2010c). Caso a regulação seja efetuada pelo próprio consórcio, deverá ser feita por um órgão específico dentro da organização do Consórcio para garantir a sua independência decisória. A 
fiscalização das atividades poderá ser terceirizada, realizada pelo próprio Consórcio ou delegada à Companhia de Saneamento do Estado (SCHINEIDER et al., 2013).

No Rio de Janeiro, por exemplo, nos Consórcios Públicos verticais, a regulação é delegada à Agência Reguladora de Energia e Saneamento Básico do Estado do Rio de Janeiro - Agenersa pela Lei Municipal 6.334 de 2012.

O modelo convencional municipal de GRSU baseia-se na organização do manejo dos resíduos por meio de um órgão municipal, Departamento de Limpeza Urbana, com atuação dentro do território municipal realizando todas as etapas de coleta, transporte, tratamento e disposição final (LIMA, 2003 apud NASCIMENTO NETO e MOREIRA, 2012).

Os Consórcios, ao se constituírem, passam a possuir personalidade jurídica própria e representatividade legal. Com isso, podem receber a titularidade da prestação dos serviços para GRSU, prestando os serviços diretamente, ou participar como ente contratante para delegar ou outorgar a prestação dos serviços, ambos mediante celebração de contrato (NASCIMENTO NETO e MOREIRA, 2012). No entanto, quando os municípios compartilham a gestão do manejo de resíduos sólidos, a forma e as responsabilidades da prestação dos serviços precisam ser bem definidas. Dessa forma, o Consórcio Público pode optar por diferentes tipos de prestação de serviços listados no Quadro 5.

\section{Quadro 5 - Tipos de Prestação de Serviços Públicos de RSU pelos Consórcios Públicos}

\begin{tabular}{|cc|}
\hline Tipo & Contrato \\
\hline Terceirizado & $\begin{array}{c}\text { Contrato de operação, exclusivo de prestação mediante } \\
\text { licitação (regido pela lei 8.666/93) }\end{array}$ \\
$\begin{array}{c}\text { Concessão Comum ou } \\
\text { Parceria Público-Privada }\end{array}$ & $\begin{array}{c}\text { Contrato de Concessão Comum (lei 8.987/95) ou } \\
\text { (PPP) }\end{array}$ \\
$\begin{array}{c}\text { Contrato de PPP (lei 11.079/2004) } \\
\text { do Estado }\end{array}$ & do Estado \\
Próprio Consórcio - & Cada município realiza um Contrato de Programa com o \\
Contrato de & Consórcio Público \\
Programa & \\
\hline
\end{tabular}

Fonte: adaptado de SCHINEIDER et al.(2013).

Pode-se destacar a prestação do serviço realizada pelo próprio Consórcio que, de acordo com as condições estabelecidas no Protocolo de Intenções, poderá prestar os serviços 
de coleta, transporte, tratamento e disposição final dos RSU. Com isso, se um Consórcio é formado por três municípios, cada um dos municípios terá um contrato com o Consórcio; o contrato a ser celebrado é o contrato de programa. O contrato de programa é regulamentado pela LCP e, de acordo com a Lei de Licitações 8.666, art. 24, XXVI, dispensa a licitação. Ressalta-se que, de acordo com a Lei, é necessário criar uma Comissão composta inclusive por representantes dos usuários para fiscalizar os contratos de programa.

\subsection{Formas de obtenção de receita para a instalação e manutenção das atividades}

Independentemente da prestação dos serviços pelos Consórcios (Quadro 5) existem formas de recebimento de transferência de recursos aos Consórcios, estabelecidos pela LCP e relacionados por Ribeiro (2007) e Schneider et al. (2013) e que diferenciam-se quando há prestação de serviços pelos Consórcios conforme apresentado no Quadro 6.

Quadro 6 - Formas de obtenção de receita pelos Consórcios Públicos

\begin{tabular}{|c|c|c|}
\hline & Tipo & Definição \\
\hline \multirow{3}{*}{$\begin{array}{l}\text { Na realização da } \\
\text { prestação de } \\
\text { serviços }\end{array}$} & $\begin{array}{c}\text { Contrato de } \\
\text { Programa }\end{array}$ & $\begin{array}{l}\text { Contrato realizado por cada membro consorciado quando o } \\
\text { próprio Consórcio presta os serviços aos entes consorciados. } \\
\text { Os recursos são transferidos pelos entes consorciados, que são } \\
\text { os contratantes e o Consórcio, é o contratado. Nesse caso, o } \\
\text { Consórcio não poderá regular e fiscalizar os serviços que ele } \\
\text { próprio prestar. }\end{array}$ \\
\hline & $\begin{array}{l}\text { Contrato de } \\
\text { operação } \\
\text { pela } \\
\text { prestação de } \\
\text { serviço }\end{array}$ & $\begin{array}{l}\text { Contrato realizado com entes da Federação não consorciados; o } \\
\text { contrato será regido pela Lei de Licitações se o ente contratante } \\
\text { integrar a Administração Pública. }\end{array}$ \\
\hline & $\begin{array}{l}\text { Cobrança e } \\
\text { arrecadação } \\
\text { de tarifas ou } \\
\text { outros preços } \\
\text { públicos }\end{array}$ & $\begin{array}{l}\text { Referente à prestação de serviços ou uso e/ou outorga de uso de } \\
\text { bens públicos. Os entes consorciados precisam autorizar a } \\
\text { cobrança. }\end{array}$ \\
\hline \multirow{2}{*}{$\begin{array}{l}\text { Independentemente } \\
\text { da prestação dos } \\
\text { serviços }\end{array}$} & $\begin{array}{l}\text { Contrato de } \\
\text { rateio }\end{array}$ & $\begin{array}{l}\text { Forma obrigatória de transferência de recursos do orçamento de } \\
\text { cada ente consorciado ao Consórcio para a manutenção da } \\
\text { infraestrutura do Consórcio. Os recursos não podem ser usados } \\
\text { para despesas genéricas. O Consórcio deverá prestar contas de } \\
\text { como os recursos foram aplicados para que as informações } \\
\text { constem no orçamento de cada ente consorciado. }\end{array}$ \\
\hline & $\begin{array}{l}\text { Convênios } \\
\text { ou contrato } \\
\text { de repasse ou } \\
\text { transferência } \\
\quad \text { fundo a } \\
\quad \text { fundo }\end{array}$ & $\begin{array}{l}\text { Transferências de recursos realizadas por entes da Federação } \\
\text { não consorciados. Os contratos de repasse precisam de uma } \\
\text { instituição financeira para intermediar os recursos advindos de } \\
\text { Fundos e programas governamentais. }\end{array}$ \\
\hline
\end{tabular}

Fonte: Elaboração própria, a partir de BRASIL, 2005; BRASIL, 2007a; RIBEIRO, 2007; SCHINEIDER et al., 2013. 
Porter (2002) e Magalhães (2009) ressaltam que, ao se impor instrumentos de comando e controle mais rigorosos por causa da preocupação com a saúde e meio ambiente, os custos da prestação dos serviços aumentam. Isto se deve à incorporação de atividades que não estavam sendo realizadas anteriormente: planejamento, regulação, fiscalização, controle social, coleta seletiva, estações de triagem, e construção, operação, fechamento e monitoramento do pós-fechamento de aterros sanitários. Com isso, para o cumprimento da PNRS, os Consórcios Públicos precisam de meios que financiem a prestação dos serviços de GRSU como um todo, incluindo a manutenção dos serviços.

De acordo com o diagnóstico do manejo de resíduos sólidos urbanos de 2011, o Sistema Nacional de Informações sobre Saneamento - SNIS (2013) indicou que, da amostra de 2.100 municípios que participaram da pesquisa, 53\% não cobravam pelos serviços regulares de coleta, transporte e destinação final de RSU. O mesmo diagnóstico assinalou que a receita arrecadada com a cobrança cobre pouco menos da metade dos custos envolvidos para a realização das atividades, mesmo nas regiões Sul e Sudeste, onde a arrecadação é maior.

As questões legais já foram uma das causas da dificuldade de se implementar a cobrança pelos serviços para o manejo de resíduos sólidos e garantir a remuneração dos custos dos serviços prestados. No entanto, atualmente, a cobrança pelos serviços possui apoio nos instrumentos de comando e controle. A LSB e a PNRS garantem a cobrança dos serviços de manejo de RSU para cobrir os seus gastos e assegurar a sustentabilidade econômicofinanceira do município ou Consórcio Público. Amparo é encontrado também na LCP, que garante a cobrança pela prestação dos serviços, conforme autorização do ente consorciado.

A Lei possibilita que a base de cálculo seja fundamentada em diferentes formas de tributação: nível de renda da população, características dos lotes urbanos, peso ou volume médio coletado por habitante ou por domicílio, ou em mecanismos econômicos de incentivo à minimização da geração de resíduos e a recuperação dos resíduos gerados (BRASIL, Art.35, 2007; Art. 14 e 45, 2010a). Neste sentido, os PMGIRS e os PIGRS precisam ter em seu conteúdo mínimo um sistema de cálculo dos custos da prestação dos serviços de manejo de resíduos sólidos e a sua forma de cobrança (BRASIL, art. 19, 2010a; art. 50, 2010b).

Para a realização da cobrança da prestação dos serviços de RSU faz-se necessário distinguir o que são serviços divisíveis e não divisíveis, uma vez que a Constituição Federal determina que os tributos - taxa ou tarifa ${ }^{6}$, terão a sua base de cálculo regulamentada por lei

\footnotetext{
${ }^{6} \mathrm{~A}$ distinção entre taxa e tarifa, é que a taxa é cobrada pelo serviço posto à disposição, independentemente de sua utilização. As tarifas estão relacionadas à quantidade do serviço efetivamente utilizado, ou seja, paga-se
} 
municipal pela utilização, efetiva ou potencial, do serviço público específico e divisível, prestado ou posto à disposição do usuário (BRASIL, art. 145, 1988). Com isso, as atividades de coleta, transporte, tratamento e disposição final são mensuráveis e divisíveis, pois é possível determinar uma quantidade do serviço prestado a cada usuário (MAGALHÃES, 2009). Logo, é possível cobrar pela prestação desses serviços.

Por outro lado, os serviços característicos de limpeza pública, como varrição de logradouros públicos, capina, limpeza de bocas de lobo, poda de árvores em vias e logradouros públicos são indivisíveis e, portanto, não podem ser embutidos nas taxas cobradas aos indivíduos, devendo ser custeadas por outros meios do orçamento municipal (MAGALHÃES, 2009).

Ambos, produtores e consumidores, precisam de incentivos para gerar menos lixo, reutilizar e reciclar mais, sendo a aplicação de tributos uma forma de incentivo.

Não há como afirmar qual modelo de cobrança é o mais adequado ou o mais eficiente; o que se pode afirmar é que, se há custos externos envolvidos, uma combinação de vários modelos de cobrança precisam ser aplicados.

Para Porter (2002), o objetivo principal dos tributos de lixo é a internalização dos custos da coleta e disposição de RSU, para que seja induzida a conscientização da geração e a minimização da produção de resíduos.

Adicionalmente, há também outras formas de incentivo que, em vez de cobrar pela geração, remunera a não geração. Municípios, individualmente ou por meio dos Consórcios Públicos, podem encontrar outras formas de diminuir os custos dos serviços e estimular a participação e conscientização popular. Pode-se citar, por exemplo, a garantia estabelecida pela PNRS que determina o poder dos municípios em instituir incentivos econômicos aos consumidores que participam do sistema de coleta seletiva (BRASIL, art. 35, 2010a).

Neste sentido, o Quadro 7 discute alguns tipos de cobrança pela prestação dos serviços de RSU e incentivos fiscais e financeiros. Por meio de exemplos empíricos de alguns casos de municípios brasileiros abordam-se pontos positivos e gargalos identificados de cada tipo de cobrança e incentivos, que podem interferir na escolha do instrumento a ser aplicado. Ressalta-se que fatores como a aceitação pública, avaliação das características locais econômicas, sociais e culturais e custos administrativos envolvidos são pontos chaves para a eficácia da aplicação dos instrumentos apresentados.

somente o que se utiliza, por exemplo, pela medição do volume de resíduos recolhido (IPEA, 2012; MAGALHÃES, 2009). 
Ressalta-se ainda que, de acordo com a PNRS, os municípios que optam por soluções consorciadas para a GRSU possuem prioridade no acesso a recursos da União ou por ela controlado (BRASIL, art. 45, 2010a; art. 78 e 79, 2010b), sendo que a elaboração do PGIRS é condicionante para o recebimento dos recursos (BRASIL, art. 16 e 18, 2010a). Tal priorização da PNRS e outros pontos relativos ao acesso dos Consórcios Públicos a recursos da União serão aprofundados nos próximos capítulos nos estudos de caso sobre Fundos e Programas governamentais para GRSU e Consórcios Públicos para GRSU nas regiões Nordeste, Sudeste e Sul. 
Quadro 7 - Tipos de cobranças e incentivos fiscais e financeiros pela prestação dos serviços de RSU

\begin{tabular}{|c|c|c|}
\hline Tipos & $\begin{array}{r}\text { Exemplos } \\
\end{array}$ & Considerações \\
\hline $\begin{array}{c}\text { Cobrança } \\
\text { vinculada ao } \\
\text { IPTU }\end{array}$ & $\begin{array}{l}\text { Dados do SNIS (2013) revelam que dos } 986 \text { municípios que } \\
\text { especificaram a forma de cobrança dos serviços no Diagnóstico } \\
\text { do Manejo de Resíduos Sólidos Urbanos - 2011, 88,8\% } \\
\text { aplicavam uma taxa vinculada ao Imposto de Propriedade } \\
\text { Territorial Urbana (IPTU). }\end{array}$ & $\begin{array}{l}\text { Econômica e socialmente, percebem-se algumas limitações desse } \\
\text { tipo de cobrança: os recursos arrecadados vinculados ao IPTU não } \\
\text { têm garantia que sejam direcionados especificamente às melhorias e } \\
\text { despesas do setor de RSU; a cobrança não gera nenhuma forma de } \\
\text { conscientização da população para a redução da geração de RSU; } \\
\text { pressupostos para que a cobrança persista são motivos políticos e as } \\
\text { dificuldades dos municípios em implantar outros tipos de cobrança. }\end{array}$ \\
\hline $\begin{array}{c}\text { Taxa cobrada } \\
\text { pela frequência } \\
\text { da coleta e outros } \\
\text { critérios }\end{array}$ & $\begin{array}{l}\text { O município de São Bento do Sul, em Santa Catarina, realiza } \\
\text { junto com a conta de água e esgoto, desde 2006, por meio do } \\
\text { Serviço Autônomo Municipal de Água e Esgoto - SAMAE, } \\
\text { uma autarquia municipal, cobrança de taxa de acordo com o } \\
\text { número de vezes que o caminhão de coleta de lixo passa na } \\
\text { residência. O valor é fixo, sendo reajustado anualmente }{ }^{7} \text {. } \\
\text { A cidade de Campinas, em São Paulo, também utiliza como um } \\
\text { dos critérios a frequência da prestação de serviço de coleta, } \\
\text { remoção e destinação final para a cobrança de taxa de lixo, } \\
\text { dividindo a área urbana de acordo com a quantidade mínima da } \\
\text { prestação do serviço. Adicionalmente, além da frequência, } \\
\text { adotam-se um ou mais critérios de rateio para compor a base de } \\
\text { cálculo da taxa a ser cobrada, como o volume da edificação, a } \\
\text { largura do terreno e sua localização. A taxa é calculada de } \\
\text { acordo com alíquotas fixas que são determinadas pela } \\
\text { destinação do imóvel, se residencial ou comercial (CAMPINAS, } \\
1990 \text { e 1998; CAMPINAS, 2014). }\end{array}$ & $\begin{array}{l}\text { Apenas o critério da frequência da coleta não é suficiente para } \\
\text { minimizar a produção de resíduos, pois a quantidade de geração de } \\
\text { resíduos de um imóvel residencial e comercial é diferente, devendo } \\
\text { ser diferenciados no cálculo da taxa. A combinação dos critérios a } \\
\text { serem utilizados vai depender das características geográficas, } \\
\text { sociais, econômicas e urbanas da localidade. Além disso, precisa-se } \\
\text { garantir que os recursos arrecadados sejam usados especificamente } \\
\text { para o setor. } \\
\text { Outra questão relevante é a análise prévia dos custos operacionais e } \\
\text { financeiros da prestação dos serviços para que a base de cálculo da } \\
\text { taxa reflita os custos reais, como: os custos de envio dos resíduos a } \\
\text { aterros sanitários e as distâncias envolvidas, o pagamento pelos } \\
\text { serviços de coleta regular e seletiva, mecanismos de punição } \\
\text { aplicados à contratação de terceirização e não cumprimento dos } \\
\text { serviços, capacidade técnica dos agentes para a implementação e } \\
\text { acompanhamento da cobrança. }\end{array}$ \\
\hline
\end{tabular}

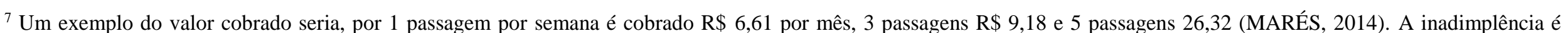

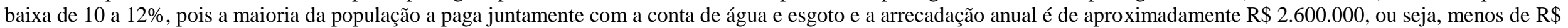
40,00 por habitante por ano - população de 74.801 habitantes (IBGE, 2010). 


\begin{tabular}{|c|c|c|}
\hline Tipos & Exemplos & $\begin{array}{c}\text { Considerações } \\
\end{array}$ \\
\hline $\begin{array}{l}\text { Tarifa por peso } \\
\text { ou volume do } \\
\text { resíduo ou tarifas } \\
\text { fixas por unidade }\end{array}$ & $\begin{array}{l}\text { O preço por unidade, pela cobrança por cada saco ou container } \\
\text { de lixo gerado pelas famílias, ou pelo peso ou volume do } \\
\text { resíduo }{ }^{8} \text {, é utilizado em vários países da Europa e Estados } \\
\text { Unidos. } \\
\text { Sterner e Coria (2012) identificaram que, nos EUA, a eficiência } \\
\text { da cobrança pela coleta de resíduos é maior nas cidades em que } \\
\text { programas de reciclagem ou postos de coleta, os chamados } \\
\text { Pontos de Entrega Voluntária - PEV, são realizados } \\
\text { simultaneamente. } \\
\text { A Lei municipal da cidade de São Paulo } 13.478 \text { de } 2002 \\
\text { permaneceu por apenas três anos ao enfrentar resistência da } \\
\text { população e uma baixa aceitação política ao determinar o } \\
\text { pagamento de taxa por volume potencial gerado de resíduos } \\
\text { declarados pelos indivíduos, baseado na natureza do domicílio } \\
\text { (IPEA, 2012). Apesar de intenção de redução da geração na } \\
\text { fonte, não havia medição direta e sim declarada pelo indivíduo. }\end{array}$ & $\begin{array}{l}\text { Este tipo de tarifa induz a mudança de comportamento, por meio da } \\
\text { cobrança pela geração, o usuário paga efetivamente pelo serviço } \\
\text { que utiliza. Logo, cobra-se menos de quem utiliza menos o serviço } \\
\text { (PORTER, 2002). } \\
\text { Custos administrativos altos podem justificar a não adesão, pois é } \\
\text { necessário um período de adaptação com investimento para } \\
\text { mecanismos de medição e instrumentos de fiscalização e } \\
\text { monitoramento para evitar o despejo ilegal ou queima (PORTER, } \\
\text { 2002; MAGALHÂES, 2009). Além disso, pode esbarrar na } \\
\text { oposição política à imposição de um novo imposto (FULLERTON } \\
\text { e KINNAMAN, 1996, apud PALMER e WALLS, 1997; STERNER } \\
\text { e CORIA, 2012). } \\
\text { A aceitação social é fundamental para o sucesso da implementação } \\
\text { e continuidade da aplicação do tributo. } \\
\text { Devem-se adotar medidas que garantam a equidade da prestação, } \\
\text { particularmente para a população pobre como, por exemplo, a } \\
\text { metodologia de desconto para população de baixa renda mediante } \\
\text { comprovação adotada nas contas de água e luz de alguns estados. }\end{array}$ \\
\hline
\end{tabular}

${ }^{8}$ Este tributo corretivo, no qual o poluidor deve ser cobrado com os custos das externalidades, trata-se do tributo pigouviano, ou seja, o tributo sobre a externalidade proposto inicialmente por Pigou em 1932, na qual a condição ótima da cobrança do tributo deve ser igual ao dano marginal causado. Logo, a diferença entre o custo marginal social e o privado é a externalidade, e o valor do tributo deveria ser o mesmo da externalidade (STERNER e CORIA, 2012).

${ }^{9}$ Este instrumento é conhecido nos Estados Unidos como pay-as-you-throw, maiores informações de como o sistema funciona nos EUA podem ser obtidos em: http://www.epa.gov/epawaste/conserve/tools/payt/index.htm 


\begin{tabular}{|c|c|c|}
\hline Tipos & Exemplos & Considerações \\
\hline $\begin{array}{l}\text { Incentivo: IPTU } \\
\text { Verde e Depósito- } \\
\text { Reembolsável }\end{array}$ & $\begin{array}{l}\text { Os municípios de Guarulhos - SP e Venda Nova do Imigrante - } \\
\text { ES sancionaram leis (GUARULHOS, 2010; VENDA NOVA } \\
\text { DO IMIGRANTE, 2011) para incentivar, por meio de } \\
\text { benefícios fiscais, critérios à sustentabilidade nas edificações, } \\
\text { entre eles a separação de resíduos sólidos com descontos sobre } \\
\text { o IPTU, instrumento chamado de IPTU Verde. As Leis } \\
\text { estabelecem autorização para uma redução fiscal de } 3 \text { a } 5 \% \text { aos } \\
\text { condomínios horizontais ou verticais que, mediante } \\
\text { comprovação, adotem medidas de separação de resíduos sólidos } \\
\text { e destinem sua coleta para reciclagem e aproveitamento. } \\
\text { Outro instrumento de incentivo é o depósito reembolsável, no } \\
\text { qual são os consumidores os responsáveis pela triagem dos } \\
\text { materiais recicláveis e o envio a um ponto de coleta em troca de } \\
\text { um subsídio pelo material. }\end{array}$ & $\begin{array}{l}\text { O IPTU Verde pode auxiliar na conscientização da população. No } \\
\text { entanto, por ser instrumento recente ainda não há dados sobre os } \\
\text { custos de monitoramento, aumento da reciclagem e redução dos } \\
\text { custos da gestão municipal que comprovem a sua eficieincia. } \\
\text { O depósito reembolsável tem como benefício a mudança de } \\
\text { comportamento, redução de custos de coleta e descarte em aterros } \\
\text { (IPEA,2012). As características sociais interferem diretamente } \\
\text { nesse instrumento. Nos países desenvolvidos, ele é aplicado } \\
\text { facilmente. Todavia, nos países em desenvolvimento, pela presença } \\
\text { de catadores de materiais recicláveis que atuam informalmente no } \\
\text { setor, sua aplicação precisaria ser melhor avaliada para que eles } \\
\text { sejam incluídos no processo. } \\
\text { Ambos os instrumentos precisam de mecanismos complementares } \\
\text { para resolver a questão da conscientização para separação dos } \\
\text { resíduos. }\end{array}$ \\
\hline
\end{tabular}




\begin{tabular}{|c|c|c|}
\hline Tipos & Exemplos & $\begin{array}{r}\text { Considerações } \\
\end{array}$ \\
\hline $\begin{array}{l}\text { Incentivo: } \\
\text { Imposto sobre } \\
\text { Circulação de } \\
\text { Mercadorias e } \\
\text { Serviços (ICMS) } \\
\text { Verde ou } \\
\text { Ecológico para } \\
\text { GRSU }^{10}\end{array}$ & $\begin{array}{l}\text { O setor de manejo de resíduos sólidos urbanos tem aparecido } \\
\text { como um dos setores estimulados para a obtenção do benefício. } \\
\text { Como exemplo, podem-se citar os estados do Ceará, } \\
\text { Pernambuco, Piaú, Goiás, Mato Grosso do Sul e Rio de Janeiro } \\
\text { que possuem o manejo de resíduos sólidos urbanos como um } \\
\text { dos critérios de repasse do ICMS Ecológico aos municípios }{ }^{11} \text {. } \\
\text { No que concerne aos Consórcios Públicos, cada legislação } \\
\text { estadual define os critérios de repartição do imposto aos } \\
\text { municípios integrantes de Consórcios que possuam aterro } \\
\text { compartilhado ou qualquer serviço de manejo de RSU. Para } \\
\text { Pernambuco, por exemplo, há distribuição igual aos municípios } \\
\text { integrantes do Consórcio, determinado por critério de pontuação } \\
\text { para ter direito ao repasse (PERNAMBUCO, 2001). } \\
\text { Com o Consórcio, o município consorciado tem direito à } \\
\text { pontuação caso destine ao aterro compartilhado, no mínimo, } \\
\text { 80\% dos resíduos sólidos gerados em seu município. Ressalta-se } \\
\text { que, os municípios podem ser inabilitados ou perderem a } \\
\text { pontuação caso possuam autos de infração, problemas de } \\
\text { operação, presença de catadores e crianças em lixões, licenças } \\
\text { vencidas, classificação da disposição como aterro sanitário, mas } \\
\text { sua operação é de aterro controlado ou lixão, entre outros casos. }\end{array}$ & $\begin{array}{l}\text { Práticas ambientais e sociais são determinadas por lei, mas muitas } \\
\text { vezes não são fiscalizadas ou monitoradas por carência de quadro } \\
\text { técnico municipal. Com isso, a fiscalização necessária para } \\
\text { determinar se o município tem direito ao repasse do ICMS } \\
\text { Ecológico é uma ferramenta adicional e eficaz para monitorar a } \\
\text { operação dos aterros sanitários e incentivar os municípios a } \\
\text { cumprirem com as regras de operação dos aterros e critérios do } \\
\text { ICMS Ecológico, além de ser uma forma de incluir o estado como } \\
\text { agente fiscalizador. Além de auxiliar a fiscalização e } \\
\text { monitoramento dos aterros sanitários, a instituição do ICMS } \\
\text { Ecológico complementa a receita municipal para a GRSU. } \\
\text { Adicionalmente, é um instrumento de política pública que incentiva } \\
\text { ao esforço máximo municipal, pois quanto mais investimento e } \\
\text { melhores resultados realizados pelo município no gerenciamento de } \\
\text { resíduos, maiores os repasses do ICMS Ecológico as prefeituras } \\
\text { recebem. }\end{array}$ \\
\hline
\end{tabular}

${ }^{10} \mathrm{O}$ ICMS é um imposto que o governo estadual arrecada sobre a circulação de mercadorias e serviços. Do montante que o estado arrecada, ele distribui um quarto a todos os municípios, ou seja, 25\%, o que é chamada Cota Parte (IPECE, 2009). O ICMS Ecológico ou Verde é a destinação de uma parte dos $25 \%$ aos resultados obtidos pelos municípios na área ambiental. A sua distribuição é considerada um incentivo fiscal intergovernamental e varia de acordo com a lei estadual.

${ }^{11}$ Cada estado possui legislação própria: Ceará: Lei estadual $N^{\circ}$ 14.023/2007 e Decreto $N^{\circ}$ 29.881/2009; Pernambuco: Lei estadual No 11.899/2000, Lei $\mathrm{N}^{\circ}$ estadual 12.432/2003, Decreto $N^{\circ}$ 26.030/2003, Decreto No 23.473/2001; Piauí: Lei Ordinária No 5.813/2008, Decreto nº 14.861/2012; Goiás: Lei complementar Nº 90/2011; Mato Grosso do Sul: Lei estadual $\mathrm{N}^{\circ}$ 4.219/2012; Rio de Janeiro: Lei estadual No 5.100/2007. 


\begin{tabular}{|c|c|c|}
\hline Tipos & Exemplos & Considerações \\
\hline $\begin{array}{l}\text { Créditos de } \\
\text { Carbono: } \\
\text { Mecanismo de } \\
\text { Desenvolvimento } \\
\text { Limpo - MDL }^{\mathbf{1 2}}\end{array}$ & $\begin{array}{l}\text { Estudos do IPEA (2012), PNUD (2010) e Schneider et al. } \\
\text { (2013) citam os Consórcios Públicos para disposição final de } \\
\text { resíduos sólidos em aterros compartilhados como uma solução } \\
\text { para que municípios com menor geração de resíduos obtenham } \\
\text { os benefícios do MDL. A construção em conjunto de um aterro } \\
\text { sanitário de maiores proporções por um Consórcio Público } \\
\text { contribui para garantir a viabilidade financeira do Projeto e } \\
\text { atingir ganhos de escala necessários para a captação do biogás e } \\
\text { possível aproveitamento como fonte de energia. Com o aterro } \\
\text { compartilhado, os municípios podem atingir o mínimo de } \\
\text { toneladas/dia e a altura de aterramento, dividir os custos } \\
\text { operacionais e financeiros e contribuir regionalmente com os } \\
\text { benefícios ambientais, sociais e econômicos devido a uma } \\
\text { escala maior da população. }\end{array}$ & $\begin{array}{l}\text { Os projetos de MDL precisam seguir normas ambientais e sociais. } \\
\text { Participar de um projeto de MDL é uma forma de garantir que } \\
\text { aterros compartilhados operem com licenças ambientais no prazo de } \\
\text { validade e que obedeçam aos requisitos sociais e econômicos } \\
\text { estipulados. } \\
\text { No entanto, ressalta-se que a venda de crédito de carbono pelo } \\
\text { MDL pode ser uma fonte adicional de receita e não uma solução } \\
\text { para cobrir todos os custos operacionais de um aterro sanitário. } \\
\text { Além disso, o mercado de RCE tem passado por mudanças nos } \\
\text { últimos anos incluindo o impacto da prorrogação do Protocolo de } \\
\text { Quioto em } 2012 \text { até } 2020 \text {. Entre as mudanças, observa-se a maior } \\
\text { oferta de RCE, o que tem impacto na baixa atratividade na venda } \\
\text { dos créditos pela queda nos preços. } \\
\text { Precisa-se levar em consideração a importância do planejamento } \\
\text { dos custos, pois os investimentos iniciais são elevados, o que pode } \\
\text { levar a inviabilização da execução. Por isso, a relevância dos } \\
\text { estudos de viabilidade técnica e econômica que atestarão ou não a } \\
\text { capacidade do aterro em vender RCE por meio do MDL e geração } \\
\text { de energia do biogás, sendo importante avaliação dos custos de } \\
\text { energia gerada (SCHNEIDER et al., 2013). }\end{array}$ \\
\hline
\end{tabular}

Fonte: Elaboração própria, a partir de SNIS, 2013; MARÉS, 2014; CAMPINAS, 1990 e 1998; PORTER, 2002; MAGALHÃES, 2009; STERNER e CORIA, 2012; SÃO PAULO, 2002; FULLERTON e KINNAMAN, 1996, apud PALMER e WALLS, 1997; GUARULHOS, 2010; VENDA NOVA DO IMIGRANTE, 2011; IPEA, 2012; PERNAMBUCO, 2001; PNUD, 2010; SCHNEIDER et al., 2013.

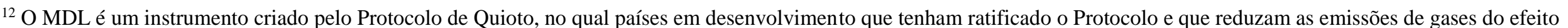

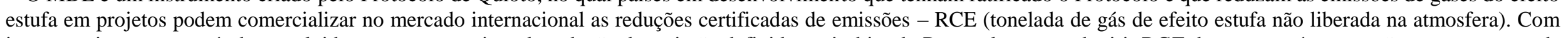

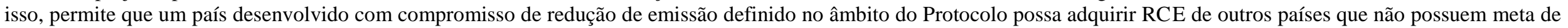
redução, em geral países em desenvolvimento, e com isso cumprir suas metas de redução de emissões (MCTI, Protocolo de Quioto, Art. 12, 1998).
} 


\section{CAPÍTULO 3: FONTES DE FINANCIAMENTO GOVERNAMENTAIS PARA CONSÓRCIOS PÚBLICOS PARA GESTÃO DE RESÍDUOS SÓLIDOS URBANOS NO BRASIL}

\subsection{Métodos e Procedimentos}

Foram avaliados Fundos e Programas que possuem linhas de financiamento para o setor de RSU.

Primeiramente, os Fundos contidos na PNRS, a saber: o Fundo Nacional do Meio Ambiente - FNMA e o Fundo Nacional de Desenvolvimento Científico e Tecnológico FNDCT (BRASIL, Art. 8, X, 2010a).

Além disso, incluíram-se o Fundo Nacional sobre Mudança do Clima - FNMC, que possui financiamento para projetos de mitigação de gases em aterros sanitários, e o Programa de Manejo de Resíduos Sólidos da Fundação Nacional da Saúde - FUNASA, que foca em linhas de financiamento para municípios de até 50 mil habitantes para projetos em todas as fases do gerenciamento de RSU.

As informações foram obtidas por meio de pesquisas bibliográficas, de relatórios disponíveis nos endereços eletrônicos das instituições responsáveis pelos Fundos e no Sistema de Convênios do Governo Federal - SICONV. Além disso, foram enviadas perguntas ao website do governo federal de acesso à informação e questionários via e-mail aos gerentes dos Fundos. Foram feitas, ainda, entrevistas com os gerentes do FNMA e da FUNASA. As pesquisas e os contatos foram realizados entre março e maio de 2014 (Quadro 8). As perguntas feitas a cada Fundo encontram-se no Apêndice A.

Ressalta-se que, adicionalmente, foi realizado contato em março de 2014 com a Secretaria Nacional de Saneamento Ambiental - SNSA, do Ministério das Cidades, sobre o Programa de Sistemas de Manejo de Resíduos Sólidos Urbanos, vinculado ao Plano Plurianual de Saneamento 2012-2015. O Programa tem como foco a implantação de infraestrutura conjugada de tratamento e disposição final de resíduos sólidos urbanos para municípios com população superior a 50 mil habitantes ou de soluções regionalizadas, como os Consórcios Públicos, para municípios com população superior a 150 mil habitantes (CIDADES, 2014). No entanto, o especialista da SNSA Francisco Leite (2014) informou que o Programa não estava vigente à época por falta de recursos. Por este motivo, este Programa do Ministério das Cidades não foi avaliado. 
Quadro 8 - Métodos empregados para obtenção de dados dos Fundos e Programa governamentais

\begin{tabular}{|c|c|}
\hline Fundos & Métodos \\
\hline $\begin{array}{l}\text { Fundo Nacional do } \text { Meio } \\
\text { Ambiente - FNMA }\end{array}$ & $\begin{array}{l}\text { Levantamento das informações disponíveis no site do Ministério } \\
\text { do Meio Ambiente; } \\
\text { Apuração dos projetos realizados para a gestão de RSU com base } \\
\text { no Relatório de Convênios de } 1990 \text { a 2013; } \\
\text { Elaboração de questionário com base nos Relatório de Convênios } \\
\text { de } 1990 \text { a } 2013 \text { e Relatório de Gestão do Exercício de } 2011 \text {; } \\
\text { Envio de questionário ao FNMA e resposta obtida da gerente } \\
\text { Miriam Miller, em } 28 \text { de março de } 2014 ; \\
\text { Entrevista com a gerente Miriam Miller em } 11 \text { de abril de } 2014 \text {. }\end{array}$ \\
\hline $\begin{array}{l}\text { Fundo Nacional de } \\
\text { Desenvolvimento Científico e } \\
\text { Tecnológico - FNDCT }\end{array}$ & $\begin{array}{l}\text { Levantamento das informações disponíveis no site do Ministério } \\
\text { da Ciência, Tecnologia e Inovação; } \\
\text { Envio de perguntas pelo canal Serviço de Informação ao Cidadão } \\
\text { - SIC }{ }^{13} \text { e documento de resposta recebido em } 22 \text { de maio de } 2014 \text {. }\end{array}$ \\
\hline $\begin{array}{l}\text { Fundo } \quad \text { Nacional sobre } \\
\text { Mudança do Clima - FNMC }\end{array}$ & $\begin{array}{l}\text { Pesquisa de informações disponíveis no site do Ministério do } \\
\text { Meio Ambiente; } \\
\text { Envio de perguntas pelo canal SIC e resposta recebida em } 22 \text { de } \\
\text { maio de } 2014 \text { pelo gerente de projeto Marcos Del Prette. }\end{array}$ \\
\hline $\begin{array}{l}\text { Programa de Manejo de } \\
\text { Resíduos Sólidos da Fundação } \\
\text { Nacional da Saúde - FUNASA }\end{array}$ & $\begin{array}{l}\text { Levantamento das informações disponíveis no site da FUNASA; } \\
\text { Elaboração de questionário com base no Manual para } \\
\text { apresentação de propostas para sistemas públicos de manejo de } \\
\text { resíduos sólidos urbanos, sistemática } 2012 \text { da Funasa; } \\
\text { Envio de questionário à FUNASA e resposta obtida pelo } \\
\text { especialista Rodrigo Passos Barreto em } 03 \text { de abril de 2014; } \\
\text { Entrevista realizada com o especialista Rodrigo Passos Barreto e } \\
\text { integrantes da equipe de Coordenação de Saneamento em Saúde - } \\
\text { COSAS em } 11 \text { de abril de } 2014 \text {; } \\
\text { Pesquisa dos convênios realizados para gestão de RSU pelo } \\
\text { SICONV; } \\
\text { Comparação dos dados obtidos com os resultados do Relatório de } \\
\text { Auditoria Operacional do Tribunal de Contas da União, Segundo } \\
\text { Monitoramento no Programa Resíduos Sólidos Urbanos, 2011. }\end{array}$ \\
\hline
\end{tabular}

Fonte: Elaboração própria.

\footnotetext{
${ }^{13}$ Endereço eletrônico: www.acessoainformacao.gov.br
} 


\subsection{Análises das informações dos Fundos e Programa governamentais pesquisados}

De acordo com as informações obtidas de cada Fundo e Programa pesquisados, foram realizadas análises com foco na prestação dos serviços de RSU e Consórcios Púbicos. As informações foram sintetizadas e, para auxiliar as análises, os dados obtidos são apresentados em quadros e gráficos.

\subsubsection{Fundo Nacional de Meio Ambiente - FNMA ${ }^{14}$}

O FNMA é um agente financiador para a implementação da Política Nacional do Meio Ambiente - PNMA e é vinculado ao Ministério do Meio Ambiente (MMA). Os recursos atuais do FNMA são provenientes do Tesouro Nacional e de recursos arrecadados pela aplicação da Lei de Crimes Ambientais. Durante sua história dispôs de recursos de contrato de empréstimo com o Banco Interamericano de Desenvolvimento (BID) e de doações, como do Projeto de Cooperação Técnica Brasil-Holanda para projetos de desertificação e mudanças climáticas e do Programa Piloto para Proteção das Florestas Tropicais (PPG7) diante de demandas específicas para gestão ambiental dos municípios.

A abrangência do atendimento do FNMA engloba a parte pública - governo, estados e municípios, e Organizações Não Governamentais - ONGs (MMA, 2014a). As temáticas do Fundo são multissetoriais e seu funcionamento é por demandas espontâneas em períodos específicos do ano com temas definidos pelo Conselho Deliberativo do FNMA, além de editais e Termos de Referência por demandas induzidas de Ministérios ou em resposta a instrumentos convocatórios, priorizando determinado tema ou região. O Conselho Deliberativo, composto por 17 membros internos e nove membros da sociedade civil, sendo esses últimos no mínimo um por região, é responsável por todas as decisões do Fundo, como a seleção dos projetos e aprovação dos Editais.

Ao se examinar a relação dos Projetos de 1990 a 2012 (MMA, 2014b), que relaciona o total de convênios financiados por demandas espontâneas e induzidas de todos os temas, observou-se que, dos 1.400 projetos desenvolvidos durante a vigência do Fundo, apenas 100 projetos foram realizados com prefeituras na área de GRSU nas categorias de gestão integrada

\footnotetext{
${ }^{14}$ Esta seção é fundamentada em entrevista concedida por MILLER. Miriam. Gerência do Fundo Nacional do Meio Ambiente. Comunicação pessoal. Entrevistas concedidas em 28 mar. 2014 e 11 abr. 2014. Perguntas disponíveis no Apêndice A.
} 
de resíduos sólidos, qualidade ambiental e sociedades sustentáveis, e apenas quatro com Consórcios Públicos para as mesmas categorias ${ }^{15}$.

Os recursos do FNMA para os 100 projetos, sem contar a contrapartida dos municípios, são da ordem de $\mathrm{R} \$ 34,6$ milhões, aproximadamente $14 \%$ do total de investimentos do Fundo ${ }^{16}$. A contrapartida dos municípios foi da ordem de R \$ 13,5 milhões, totalizando 48 milhões nas ações dos convênios (APÊNDICE B). A distribuição dos recursos por ano e por quantidade de projetos pode ser observada no Gráfico 1. Para os quatro projetos com Consórcios, os recursos do FNMA foram na ordem de dois milhões de reais e a contrapartida de $\mathrm{R} \$ 600$ mil.

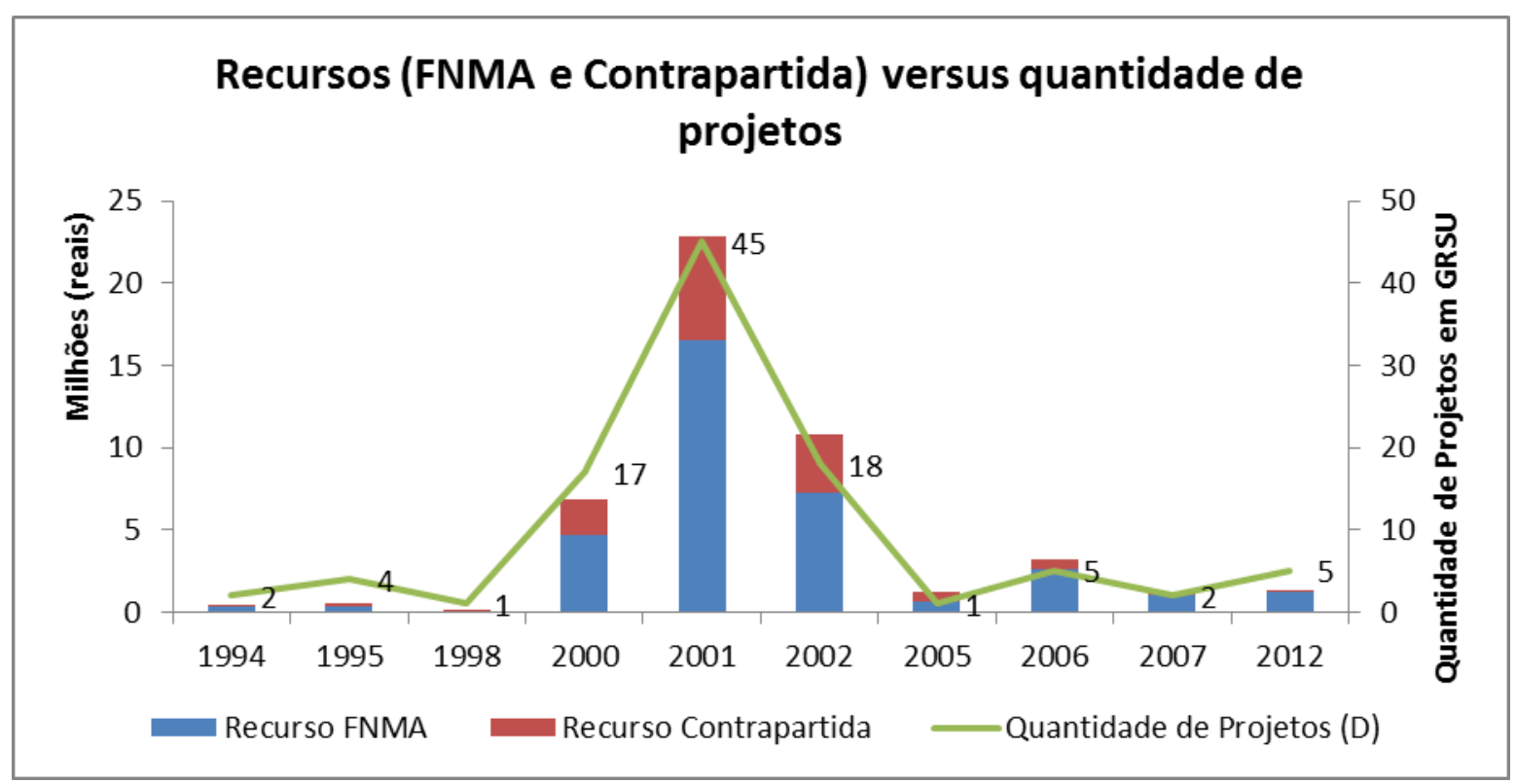

Gráfico 1 - Distribuição quantitativa anual dos projetos municipais relacionados à GRSU e os recursos do FNMA e de contrapartida.

Fonte: Elaboração própria, a partir de MMA, 2014b (APÊNDICE B).

Ao se analisar a distribuição quantitativa dos 100 projetos anualmente e os recursos repassados, observa-se que os anos de 2000, 2001 e 2002 foram os mais expressivos neste setor, com um total de 80 projetos. $\mathrm{O}$ ano de 2001 teve o maior número de projetos, com 45 convênios, o que pode ser explicado pelo lançamento de dois Editais em 2000. O edital

\footnotetext{
15 A relação dos 100 convênios encontra-se no Apêndice B. Planilha elaborada com base no Relatório de Convênios 1990-2013 (MMA, 2014b). A relação dos projetos seguiu o foco do estudo que é a GRSU, os projetos de gerenciamento de resíduos para indústrias, atividades agropastoris e outros não foram contabilizados. Além disso, os convênios federais, estaduais e com ONGs (13 projetos) com relação à GRSU também não fizeram parte do cálculo, apenas os convênios com municípios e Consórcios.

${ }^{16}$ Dados informados pelo FNMA calculam investimentos da ordem de $\mathrm{R} \$ 233$ milhões de reais para os 1.400 projetos fomentados. Disponível em: < http://www.mma.gov.br/apoio-a-projetos/fundo-nacional-do-meioambiente>. Acesso em: 03 jun.2014.
} 
FNMA n ${ }^{\circ}$ 06/2000 selecionou propostas voltadas ao Fomento a Projetos de Gestão Integrada de Resíduos Sólidos Urbanos, e o edital FNMA n ${ }^{\circ}$ 02/2000, propostas de projetos orientados à elaboração e à implantação de Planos de Gerenciamento Integrado de Resíduos Sólidos, incluindo Unidades de Tratamento, Obras de Destino Final e Coleta Seletiva em municípios com população urbana entre 20 mil a 50 mil habitantes (MMA, 2014c). No entanto, a gerente Miller entrevistada destaca que muitas propostas são recusadas por falta de capacidade técnica dos municípios de elaborar propostas que atendam aos requisitos solicitados nos Editais e de falta de comprovação de capacidade para executar os projetos.

Conforme Gráfico 2, dos 100 projetos já realizados há uma predominância para convênios com municípios de 20.001 a 100.000 habitantes. Segundo Miller (2014), a faixa populacional municipal não é um critério de escolha para aprovação das propostas. No entanto, conforme visto, um dos editais publicados especificava a faixa populacional entre 20.000 e 50.000 habitantes, o que pode ser um das justificativas para a quantidade de projetos nesta faixa populacional.

Para os quatro projetos com Consórcios Públicos não foi possível fazer a mesma análise por população por não ter sido possível identificar todos os municípios participantes da gestão compartilhada.

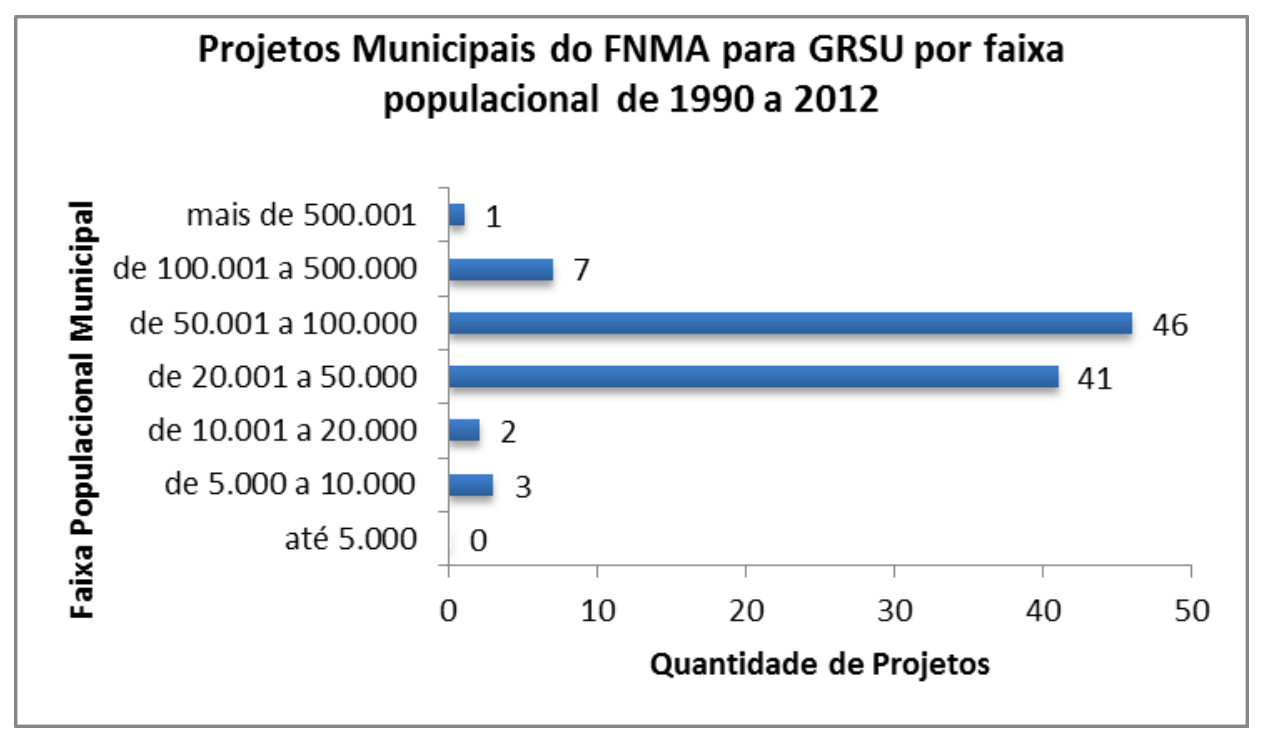

Gráfico 2 - Relação quantitativa de convênios do FNMA com prefeituras entre 1990 2012 para gestão de resíduos sólidos por faixa populacional.

Fonte: Elaboração própria, a partir MMA, 2014b (APÊNDICE B); IBGE, Censo Demográfico 2010.

Os fatores normalmente considerados na avaliação das propostas são a qualidade técnica das propostas, a distribuição dos municípios entre as regiões geográficas do país e se a justificativa apresentada no projeto comprova sua importância para o município. A 
distribuição regional dos 100 projetos analisados concentrou-se nas regiões Sudeste (32\%), Sul $(30 \%)$ e Nordeste $(26 \%)$, respectivamente. As regiões Centro-Oeste (9\%) e a Norte (3\%) tiveram pouca expressividade.

Ao analisar o montante de recursos repassados do FNMA por projeto, sem contar os recursos de contrapartida, o maior destaque foi o repasse em 2005 de cerca de $\mathrm{R} \$ 600$ mil para um projeto, com base no Edital 07/2005 para o fomento a projetos de gestão integrada de resíduos sólidos urbanos na Bacia do rio São Francisco. Os repasses por projeto em 2006 e 2007 também foram maiores comparados aos outros anos; em 2012 já se observa uma queda, conforme Gráfico 3.

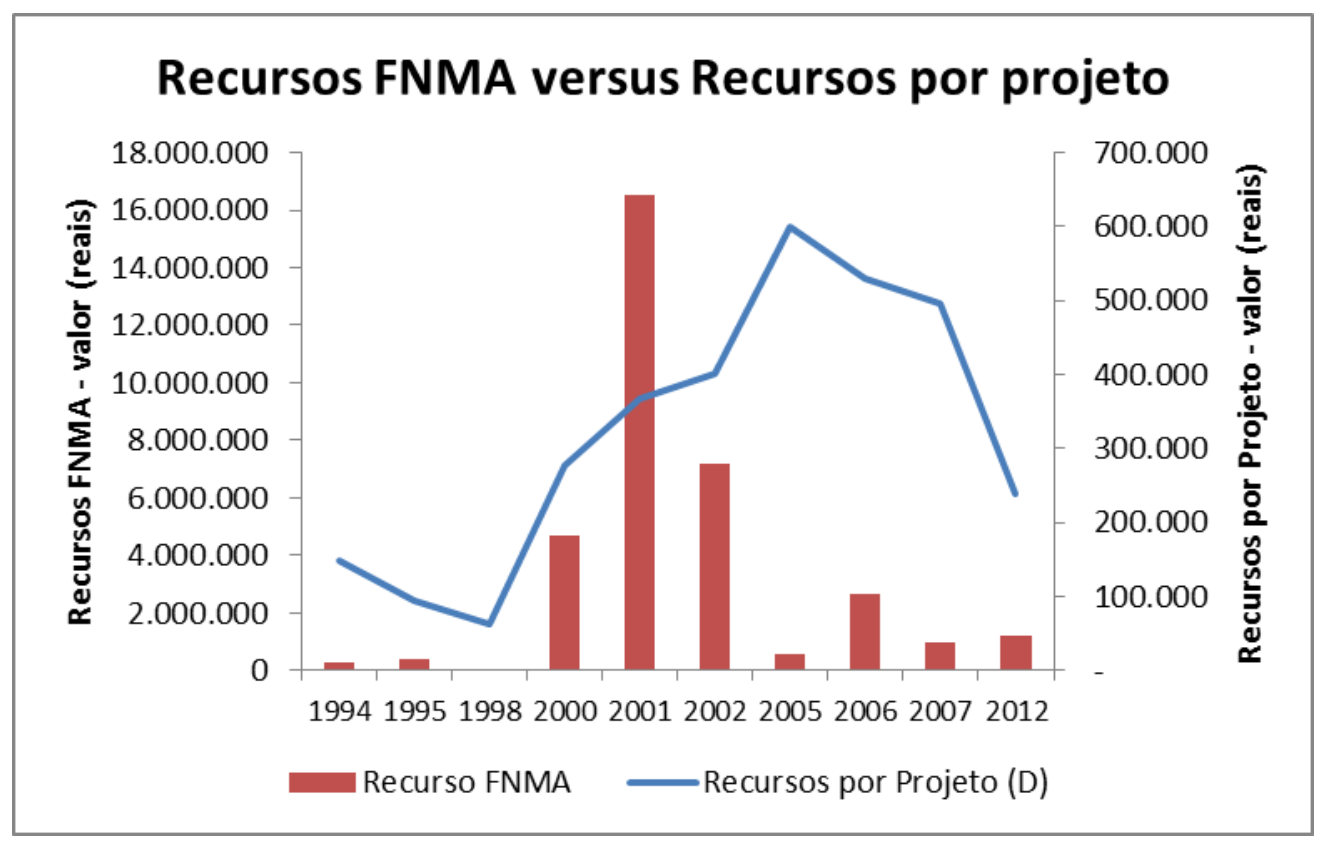

Gráfico 3 - Recursos do FNMA por projeto municipais relacionados à GRSU entre 1990 a 2012

Fonte: Elaboração própria, a partir de MMA, 2014b (APÊNDICE B).

A partir de 2009, o Fundo iniciou uma nova estratégia de redução do número de projetos financiados e aumento do valor investido em projetos estruturantes com o intuito de melhorar o acompanhamento dos convênios, uma vez que o quadro técnico do Fundo é reduzido (MMA, 2012). No âmbito geral, segundo Miller (2014), atualmente são realizados dez projetos por ano, dois por região de temas diversos por demanda espontânea, nos valores de $\mathrm{R} \$ 100.000$ a $\mathrm{R} \$ 300.000$ e dois editais por ano de temas específicos por demandas induzidas, em valores acima de $\mathrm{R} \$ 500.000$.

Pelo exposto, embora o FNMA conste como um dos instrumentos da PNRS, nota-se que o Fundo atende diversos temas, sendo que a GRSU teve pouca participação, apenas 14\% dos recursos nos 24 anos de existência do Fundo. Mesmo com a PNRS, a GRSU não tem 
como ser o foco da aplicação do Fundo, pois o seu compromisso é com a PNMA como um todo. Além disso, de acordo com Miller (2014), não há previsão de aumentar o número de projetos de RSU apoiados pelo Fundo, a não ser que haja demanda pelo Governo e Ministérios, devido às exigências da PNRS. Em relação ao financiamento para os Consórcios Públicos em GRSU, também não há nenhuma estratégia de aumento de recursos para projetos com este tipo de arranjo institucional.

\subsubsection{Fundo Nacional de Desenvolvimento Científico e Tecnológico - FNDCT}

O FNDCT também é um instrumento da PNRS (Art. 8, X, 2010) e é ligado ao Ministério da Ciência, Tecnologia e Inovação - MCTI. O Fundo tem como objetivo apoiar financeiramente programas e projetos prioritários de desenvolvimento científico e tecnológico nacionais (MCTI, 2014a). O FNDCT possui Fundos Setoriais e Não Setoriais; no entanto, não há um Fundo Setorial específico para resíduos sólidos. Entretanto, observou-se nos relatórios de gestão anuais do Fundo a presença de financiamento de projetos direcionados a empresas para o desenvolvimento de ações relacionadas a resíduos sólidos de processos produtivos, retornando para o ciclo produtivo ou na criação de novos produtos com base nos resíduos como substituição de outro produto, além de aproveitamento em processos de geração de energia, entre outros (MCTI, 2014b).

As pesquisas realizadas e as respostas recebidas não possibilitam afirmar que o FNDCT pode ser uma opção de recursos para a gestão municipal de RSU para municípios e Consórcios. A hipótese inicial da análise era de que o Fundo poderia ser uma fonte de financiamento para capacitação e formação técnica de gestores e servidores municipais nos processos de GRSU e formação de Consórcios. No entanto, não há dados disponíveis para avaliar esta hipótese ${ }^{17}$.

\footnotetext{
17 Por causa da indisponibilidade de informações no site do MCTI, foram enviadas algumas perguntas específicas (APÊNDICE A) ao MCTI pelo canal do Serviço de Acesso à Informação - SIC. No entanto, as respostas recebidas direcionavam para as informações no site e informaram que as perguntas enviadas não se enquadravam na Lei de Acesso à Informação (BRASIL, 12.527, 2011), ou seja, não constituem informação ou documento que possa ser disponibilizado nos termos da referida Lei.
} 


\subsubsection{Fundo Nacional sobre Mudança do Clima - FNMC ${ }^{18}$}

O FNMC iniciou suas operações em 2011 e é um instrumento da Política Nacional sobre Mudança do Clima - PNMC. O FNMC tem por finalidade financiar projetos, estudos e empreendimentos que visem à mitigação da mudança do clima e à adaptação a seus efeitos (MMA, 2014d). As demandas do Fundo são de diversas naturezas, e sua base é a consonância do projeto proposto com a PNMC.

Embora o Fundo Clima não seja um instrumento da PNRS e não possua projetos diretos para o setor de resíduos, segundo Prette (2014), o Fundo Clima pode apoiar projetos voltados para a racionalização da limpeza urbana e disposição de resíduos com geração de energia, desde que resultem em aproveitamento energético, mediante linha de ação reembolsável para resíduos.

O Fundo apoia os projetos mediante solicitação direta de financiamento ao Banco Nacional de Desenvolvimento Econômico e Social (BNDES) ou mediante seleção por meio de Editais do MMA. Para o setor de resíduos, o gerente citou como exemplo o Edital MMA/FNMC $n^{\circ}$ 01/2014, que tem como linha de ação projetos e estudos para aproveitamento energético do biogás (aterros sanitários, dejetos da pecuária) e de energia solar (MMA, 2014e).

O Fundo pode ser uma opção de financiamento de projetos para mitigação dos gases gerados nos aterros sanitários e para Consórcios Públicos que possuam a gestão compartilhada de aterros sanitários com o intuito de geração de energia. No entanto, ressaltase a importância de municípios e Consórcios Públicos realizarem estudos de viabilidade técnica e financeira, pois vários fatores interferem na capacidade do aterro de gerar energia por meio do biogás, tais como composição e quantidade dos resíduos, condições climáticas entre outros.

\footnotetext{
${ }^{18}$ Esta seção é fundamentada em PRETTE, Marcos Del. Gerência de Projeto, Secretaria de Mudanças Climáticas e Qualidade Ambiental. Comunicação Pessoal. Perguntas (APÊNDICE A) enviadas ao SIC e resposta obtida pelo Ofício- SIC MMA/653 em 22 mai. 2014.
} 


\subsubsection{Programa para o manejo de resíduos sólidos da Fundação Nacional da Saúde - FUNASA $^{19}$}

A FUNASA possui um Programa para o manejo de RSU e seus recursos são procedentes do Orçamento Geral da União - OGU e emendas parlamentares. O alvo do Programa da Funasa são municípios com até 50.000 habitantes e o objeto do financiamento possibilita recursos para projetos em todas as fases: coleta e transporte, aquisição de veículos, construção de unidades de transbordo e equipamentos; destinação final, para construção de galpão de triagem e compostagem, aquisição de veículos e equipamentos; e disposição final, para a construção de aterro sanitário e aquisição de equipamentos para operacionalização (FUNASA, 2014b).

O programa da última portaria $\left(n^{\circ}\right.$ 1.225) de 2013 faz parte da ação orçamentária $10 \mathrm{GG}^{20}$ do Plano Plurianual 2012-2015 do Governo Federal. Nota-se que a partir da portaria mencionada, começou-se a priorizar os municípios com soluções consorciadas constituídas pela maioria simples de municípios com população de até 50.000 habitantes e propostas que incluam a coleta seletiva com a participação de cooperativas ou associações de catadores de materiais reutilizáveis e recicláveis (FUNASA, 2014b). A priorização no acesso e outras alterações trazidas na referida portaria fazem-se em consonância à PNRS.

Adicionalmente, pode-se deduzir que outras mudanças no processo de seleção das propostas surgiram das sugestões propostas pelo Segundo Monitoramento de Auditoria do Tribunal de Contas da União - TCU (2011), que analisou os recursos destinados ao Programa de Resíduos Sólidos Urbanos da Funasa, no período de janeiro de 2000 a abril de 2011. Constatou-se que, em convênios para construção de aterros sanitários, 38\% do valor transferido foram desperdiçados, aproximadamente $\mathrm{R} \$ 20$ milhões, pois os aterros foram abandonados ou retornaram à condição de lixões.

Um dos pontos principais para a solicitação de financiamentos governamentais referese ao PGIRS, que é uma condição primária para a apresentação das propostas, requisito incorporado de acordo com a PNRS. No entanto, Barreto (2014) relata que poucas propostas

\footnotetext{
${ }^{19}$ Esta seção é fundamentada em entrevista concedida por BARRETO, Rodrigo. Coordenação de Saneamento em Saúde, FUNASA. Comunicação Pessoal. Entrevistas concedidas em 03 e 11 abr. de 2014. Perguntas disponíveis no Apêndice A.

${ }^{20}$ Ação Orçamentária 10GG - Implantação e melhoria de sistemas públicos de manejo de resíduos sólidos em municípios de até 50.000 habitantes, exclusive de regiões metropolitanas ou Regiões Integradas de Desenvolvimento Econômico - RIDE (MPOG, 2014).
} 
são aproveitadas, pois não atendem as exigências mínimas do Edital, como licenças ambientais ou comprovação da propriedade da terra, capacidade técnica em preparar as propostas e apresentação dos PGIRS.

A falta de Planos é apontada como uma das maiores dificuldades dos municípios para a elegibilidade ao financiamento. Barreto (2014) informou que cerca de $70 \%$ das propostas apresentadas no último Edital não possuíam nenhum dos Planos e foram recusadas. Dados do IBGE (2014a) reforçam esta declaração ao constatar que apenas 33,48\% (1.865) dos municípios brasileiros possuem PGIRS e 30\% (1.669) possuem Plano de Saneamento Básico - PSB que contemple o serviço de limpeza urbana e manejo de resíduos sólidos. Observa-se no Gráfico 4 que as faixas populacionais municipais atendidas pelo Programa da FUNASA, até 50 mil habitantes, possuem uma menor porcentagem de Planos do que as acima de 50 mil.

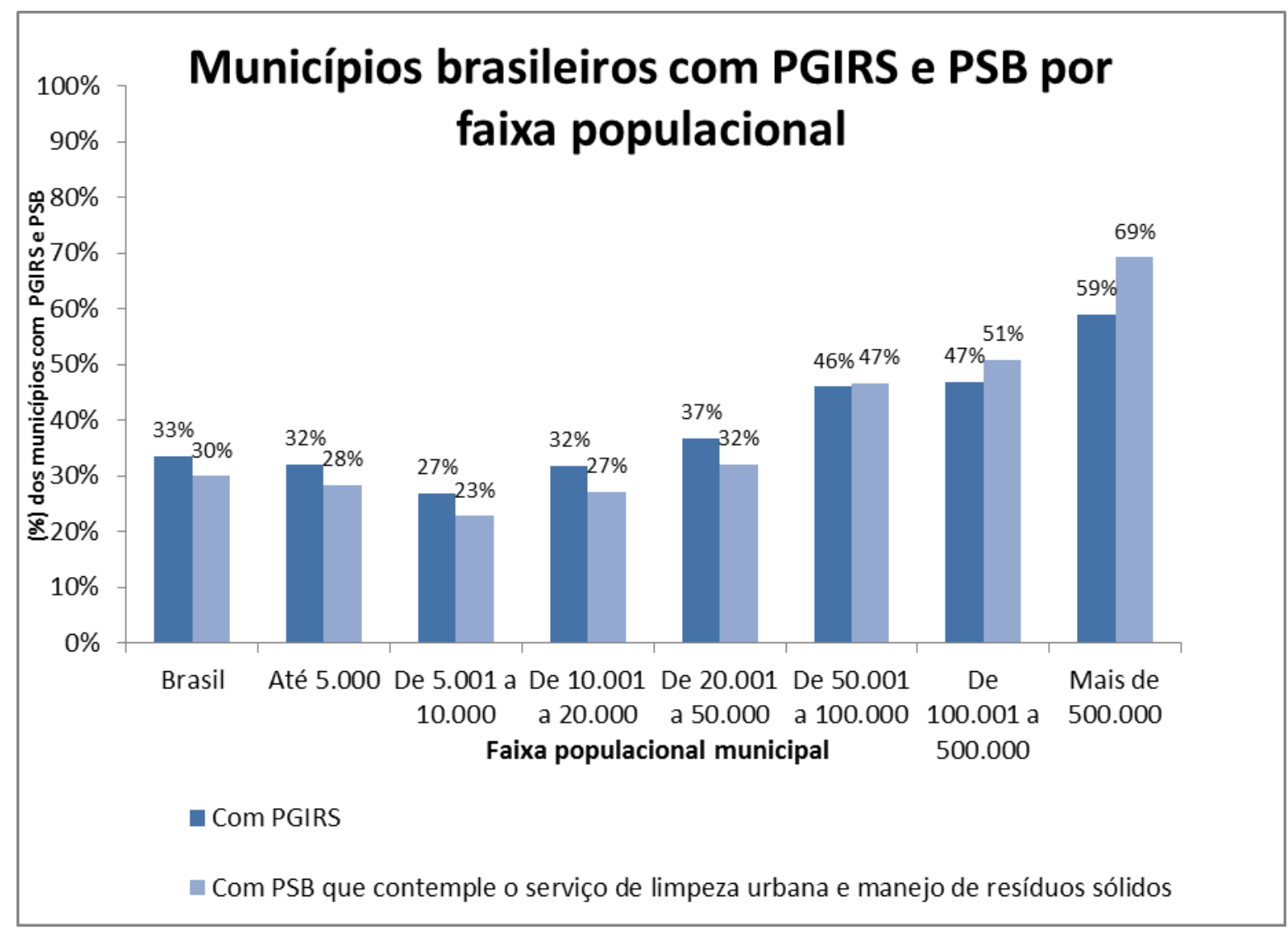

Gráfico 4 - Distribuição por faixa populacional dos municípios com PGIRS e com PSB que contemple o serviço de limpeza urbana e manejo de resíduos sólidos. Fonte: adaptado de IBGE, 2014a.

O TCU (2011), que por um lado sugere que a Funasa condicione a celebração dos convênios à apresentação dos Planos, por outro reconhece que os municípios de pequeno porte possuem carência de técnicos capacitados para orientar e executar os Planos. Com isso, 
a auditoria sugere que recursos do Programa sejam aplicados primeiramente no desenvolvimento da capacidade institucional dos municípios, para que não sejam alocados recursos em projetos que não terão uma gestão adequada resultando em desperdício de recursos públicos. Todavia, ainda não se constatou esta possibilidade no Programa.

Outra alteração aplicada na última portaria $\left(n^{\circ} 1.225\right)$ de 2013, relatada por Barreto (2014), foi a exigência de apresentação de propostas que possuam projetos com soluções integrais, para que o sistema funcione como um todo. Este requisito foi estabelecido na PNRS e observado como uma das orientações do TCU (2011). Com isso, caso o município ou Consórcio queira recursos para veículos compactadores, ele deverá possuir disposição final adequada; caso não possua, a proposta deverá conter também a solicitação de recursos para o caminhão e para o aterro sanitário.

Questão relevante refere-se à comprovação da auto-sustentação dos serviços financiados após o término do financiamento. Conforme levantamento do TCU (2011), a maioria dos municípios se preocupa com a construção e inauguração do empreendimento, no caso da construção de aterros sanitários, sendo que a estrutura administrativa e financeira para garantir a manutenção não é priorizada. Esse fato é acentuado ao se constatar que a maioria dos municípios não possui cobrança de tributo para os serviços prestados de manejo de RSU, o que representa uma sobrecarga no orçamento municipal, pois não há receita para cobrir os gastos. Em vista disso, a Funasa tem solicitado, nas propostas, a comprovação de projetos que visem à sustentabilidade dos sistemas implantados e considerem os aspectos administrativos, tecnológicos, financeiros e a participação da comunidade (FUNASA, 2014b).

Nos últimos cinco anos, de 2009 a 2013, foram realizados 1007 projetos com municípios e 13 com Consórcios Públicos (SICONV, 2014) para as atividades de manejo de resíduos sólidos. A distribuição dos projetos com os municípios durante esse período pode ser observada no Gráfico 5. Na análise do total dos projetos entre 2009 e 2013, observa-se uma concentração maior de projetos com a região Sudeste, seguidos pela região Nordeste, Sul e Centro-Oeste, ficando a região Norte com menos projetos. O ano subsequente à criação da PNRS, 2011 foi o ano com maior número de projetos, 336, no entanto, observa-se uma queda nos anos de 2012 e 2013.

A participação dos Consórcios ainda é pouco expressiva, apesar da priorização na última seleção. Em 2013 foram apenas seis projetos. Em vista disso, Barreto (2014) observa que não há como avaliar se a priorização no acesso aos recursos incentivou a formação de Consórcios, pois a demanda feita pelos Consórcios ainda não é significativa. 


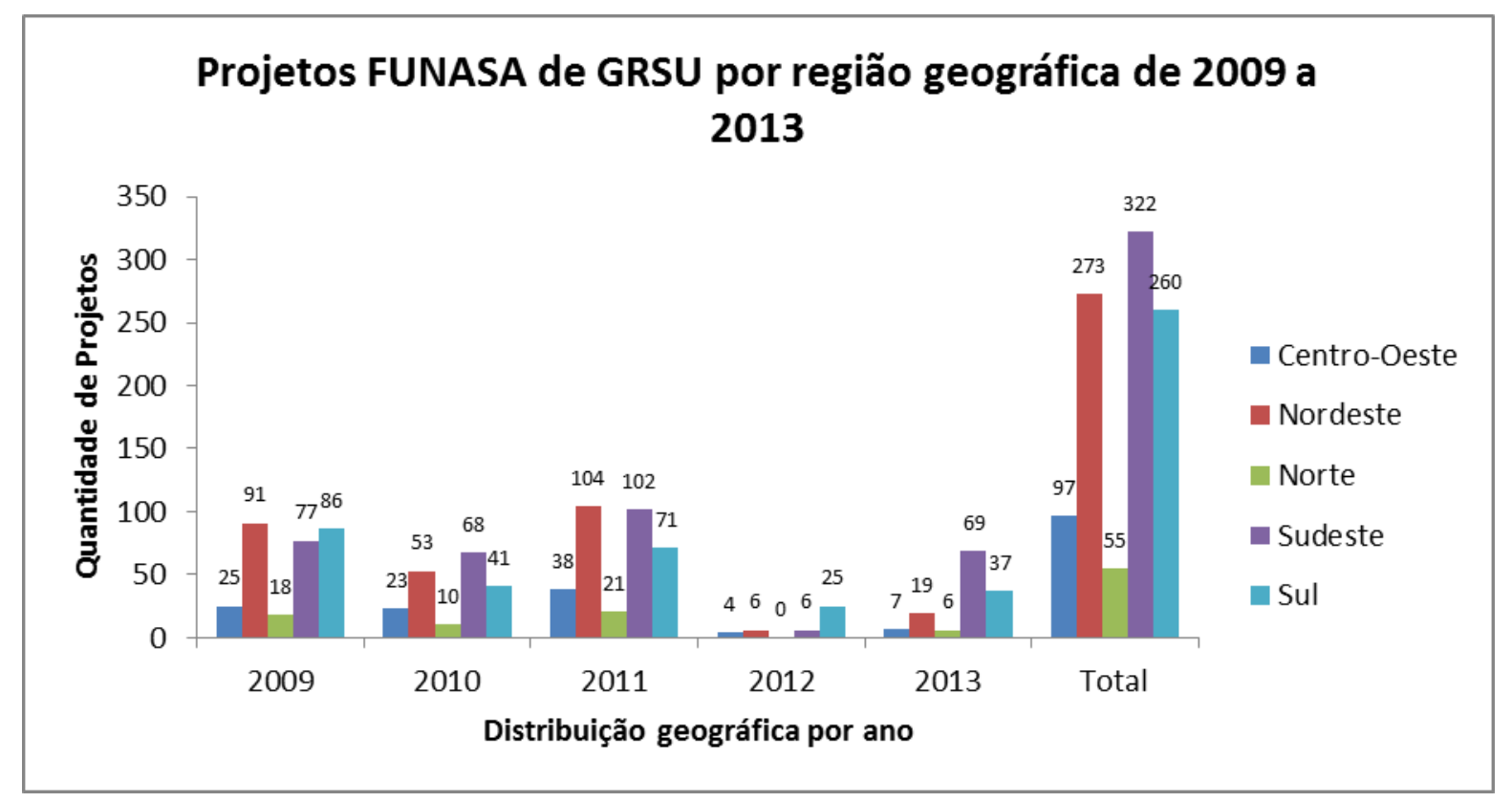

Gráfico 5 - Quantidade de projetos da Funasa com municípios por região geográfica no período de 2009 a 2013.

Fonte: Elaboração própria, a partir de SICONV, 2014.

\subsubsection{Considerações sobre os Fundos e Programa pesquisados}

Com base nas análises realizadas, o Quadro 9 apresenta uma síntese das considerações sobre os Fundos estudados, destacando o grau de influência da PNRS no acesso de municípios e Consórcios Públicos aos recursos dos referidos Fundos e Programa governamentais, a avaliação na execução desses recursos e a identificação de falhas de governo nos resultados encontrados de cada Fundo.

A presença do financiamento para projetos de manejo de RSU nos Fundos e Programas estudados em quatro setores diferentes: meio ambiente, tecnologia e inovação, mudanças climáticas e saúde denota a transversalidade setorial do setor e constata que a problemática da GRSU não está presente apenas nas agendas de políticas públicas de resíduos sólidos e de saneamento. Consequentemente, exige dos setores impactados ações por meio de políticas, programas e projetos governamentais.

Por um lado, a percepção da interdependência entre políticas públicas é relevante para a formulação de políticas, planos, programas e projetos transversais, que naturalmente influenciam e são influenciados por outras políticas, como no caso da PNRS, que, como visto, pode influenciar e é influenciada por outras políticas. Por outro lado, questiona-se a falta de transversalidade setorial entre os diversos Ministérios e Agências do governo, conforme atestado pelo TCU (2011) no caso da Funasa, entre o MMA, Ministério das Cidades e Funasa. 
Nesse caso, a falta de articulação entre os setores que, de alguma forma, estão envolvidos ou são impactados pelas ações e atividades do manejo de RSU, pode levar a conflitos de ações e mau emprego de recursos públicos.

Outra questão observada, especificamente em relação ao FNMA e ao Programa de Manejo de Resíduos Sólidos da Funasa, é que os problemas de eficiência e eficácia não estão relacionados à falta de recursos do Fundo e Programa, mas à carência técnica de ambos os lados, do governo federal que disponibiliza os recursos e do governo municipal que almeja o recebimento. Os municípios não conseguem cumprir as exigências dos Editais, por falta de PGIRS, por deficiência técnica em atender os requisitos das propostas, como propor soluções integrais ou comprovar capacidade de auto-sustentação após a finalização do recebimento dos recursos, como por exemplo, capacidade de manutenção das infraestruturas instaladas.

O governo federal falha no planejamento, na falta de monitoramento durante e após o repasse dos recursos, na falta de parâmetros para decidir quais propostas devem ser aceitas, no quadro de servidores reduzidos e na falta de capacidade técnica no setor de resíduos sólidos. Pelo exposto, afirmar que o problema é a falta de recursos seria simplificar a situação, já que há falta de planejamento, capacidade técnica e monitoramento. Nesse sentido, a UNEP (2009) adverte que os processos de avaliação de políticas precisam ser implementados desde o início de políticas, programas e projetos, para que dessa forma seja possível avaliar o progresso e efetuar modificações quando necessário.

Embora o FNMA e o Programa da Funasa tenham ainda pouca expressividade no repasse dos recursos aos Consórcios Públicos, ambos os gerentes entrevistados ressaltaram alguns gargalos enfrentados pelos Consórcios para o recebimento de recursos da União, como: dificuldade na determinação da área para implantação do aterro sanitário, distâncias intermunicipais, elaboração do Protocolo de Intenções e sua aprovação, ausência de recursos humanos capacitados, impedimento do recebimento dos recursos pelo Consórcio por causa da inadimplência de um dos municípios, impacto de problemas no município sede que podem afetar todos os outros municípios consorciados, mudanças na gestão e falta de sintonia entre os municípios, que podem impactar no funcionamento do Consórcio. 
Quadro 9 - Considerações sobre os Fundos e Programa governamentais pesquisados

\begin{tabular}{|c|c|}
\hline Fundos & Considerações sobre os Fundos pesquisados no estudo de caso \\
\hline FNDCT & $\begin{array}{l}\text { É instrumento da PNRS e pode ser usado como incentivo para reduzir a geração e mudar o comportamento para reutilização, reciclagem e } \\
\text { aplicação de novas tecnologias no processo produtivo. O FNDCT pode ser um instrumento de incentivo ao esforço máximo para que empresa } \\
\text { busquem formas inovadoras de reduzir os danos ambientais causados pela geração de rejeitos e resíduos de seus processos produtivos e redução } \\
\text { das externalidades negativas } \\
\text { Não foi possível constatar se a hipótese inicial do Fundo ser uma fonte de financiamento para capacitação e formação técnica de gestores e } \\
\text { servidores municipais nos processos de GRSU e formação de Consórcios é verdadeira por falta de informações e ausência de projetos para o } \\
\text { setor. }\end{array}$ \\
\hline FNMC & $\begin{array}{l}\text { Embora não seja instrumento da PNRS, o Fundo pode ser uma fonte de financiamento de projetos para mitigação dos gases gerados nos aterros } \\
\text { sanitários para municípios e Consórcios Públicos que possuam a gestão compartilhada de aterros sanitários com aproveitamento energético. } \\
\text { É um instrumento de incentivo ao esforço máximo para os municípios e Consórcios Públicos, na medida em que motiva a redução dos danos } \\
\text { ambientais ocasionados na disposição dos resíduos. Ressalta-se, no entanto, que os custos administrativos para a operacionalizaça devem ser } \\
\text { considerados, como os custos dos estudos de viabilidade e manutenção e equipamentos; assim como a composição e quantidade de resíduos, } \\
\text { condições climáticas da região, entre outros fatores que interferem na viabilidade ou não da geração de energia pelo biogás produzido pelo aterro. }\end{array}$ \\
\hline
\end{tabular}

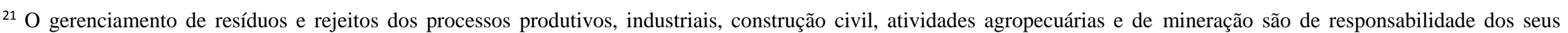
geradores e, por isso, não são foco do presente trabalho. Reconhece-se, no entanto, a importância do incentivo à inovação e desenvolvimento tecnológico do reaproveitamento dos resíduos e rejeitos dos processos produtivos para o sistema econômico. 


\begin{tabular}{|c|c|}
\hline Fundos & Considerações sobre os Fundos pesquisados no estudo de caso \\
\hline
\end{tabular}

Fonte: Elaboração própria, a partir dos resultados da pesquisa. 


\section{CAPÍTUlo 4: CONSÓRCIOS PÚBLICOS NA PRÁTICA: ESTUdO DE CASO COM 29 CONSÓRCIOS PÚBLICOS PARA A GESTÃo DE RESÍDUOS SÓLIDOS URBANOS NO BRASIL}

\subsection{Métodos e Procedimentos}

Buscou-se identificar, em um primeiro momento os Consórcios Públicos para GRSU existentes no Brasil. Como não existe nenhum Órgão Federal que centralize essas informações, realizou-se uma pesquisa nos estados brasileiros. Para isso, identificou-se em cada estado Órgãos Estaduais ou Municipais que poderiam ter as informações sobre os Consórcios e foram enviados e-mails para todos os estados, no período de março a maio de 2014. Poucos são os estados que possuem informações consolidadas dos Consórcios Públicos para GRSU no seu território e não há uma Secretaria ou Agência específica com essa informação. Não se obteve retorno de todos os e-mails enviados; algumas respostas indicaram diretamente o nome dos Consórcios Públicos nos estados, outros indicaram documentos, como os PEGIRS e relatórios, ou sites ou contatos de outras Secretarias ${ }^{22}$.

O foco do levantamento foi buscar os Consórcios Públicos que possuíssem como único objetivo a GRSU. No entanto, observou- se que a GRSU pode ser o único ou o principal componente, como também pode ser um dos componentes e objetivos. Como o intuito do estudo era identificar as características dos Consórcios com experiência na GRSU, aqueles identificados como multifinalitários, com um dos componentes sendo a GRSU, também fizeram parte da pesquisa. Entretanto, tal característica pode dificultar a identificação dos Consórcios Públicos que possuem objetivos de GRSU, pois ao realizar um levantamento pelo nome dos Consórcios, por exemplo, pode-se deixar de fora um Consórcio em desenvolvimento regional que tenha componente de GRSU e que não é classificado como tal.

\footnotetext{
22 Durante a pesquisa, identificou-se uma parceria entre a Caixa Econômica Federal, a Frente Nacional dos Prefeitos e o Programa das Nações Unidas para o Desenvolvimento - PNUD chamado Observatório dos Consórcios Públicos e do Federalismo, instituído com o objetivo de acompanhar e promover a implementação dos Consórcios de todos os setores no Brasil. Conseguiu-se a informação de que o Observatório realizou um levantamento sobre os Consórcios existentes de vários setores no Brasil, inclusive de resíduos sólidos. No entanto, não se teve acesso à relação, além de se constatar que o projeto encontra-se parado (CARNEIRO, Carlos Eduardo G. Gerência Executiva da Caixa Econômica Federal, Governo de São Paulo. Comunicação pessoal. Contato telefônico em 30 mai. 2014).

O Protocolo de Intenções do Consórcio Público, por ser publicado na imprensa oficial, poderia ser uma fonte de pesquisa, no entanto, é preciso conhecer o nome do Consórcio para realizar a busca, uma informação que era parte do objetivo da pesquisa. Além disso, ele geralmente é publicado nos Diários Oficiais dos municípios, o que dificulta a pesquisa em âmbito nacional. Adicionalmente, uma vez que os Consórcios precisam prestar contas aos Tribunais de Contas, esses poderiam ser uma fonte de pesquisa adicional, mas que por falta de tempo hábil não foi realizada.
} 
O levantamento dos Consórcios Públicos existentes para GRSU foi realizado de janeiro a maio de 2014 e apresenta resultados das respostas recebidas por e-mail, contatos telefônicos, pesquisas na Internet, em trabalhos acadêmicos sobre Consórcios específicos, leis municipais, relatórios e PEGIRS ${ }^{23}$. Após a identificação, chegou-se a uma lista com 77 Consórcios, listados no Quadro 10.

\begin{tabular}{|c|c|c|c|}
\hline \multicolumn{4}{|c|}{ Quadro 10 - Levantamento dos Consórcios Públicos para GRSU no Brasil } \\
\hline Região & & Nome do Consórcio & UF \\
\hline \multirow{2}{*}{$\begin{array}{l}\text { Centro- } \\
\text { Oeste }\end{array}$} & 1 & $\begin{array}{l}\text { Consórcio Público de Manejo dos Resíduos Sólidos e das Águas Pluviais da } \\
\text { Região Integrada do Distrito Federal e Goiás - CORSAP-DF/GO }\end{array}$ & $\begin{array}{l}\mathrm{DF} / \\
\mathrm{GO}\end{array}$ \\
\hline & 2 & Consórcio Intermunicipal de Meio Ambiente - CIMA & GO \\
\hline Norte & 3 & $\begin{array}{l}\text { CIMCERO - Consórcio Público Intermunicipal da região centro Leste do } \\
\text { Estado de Rondônia }\end{array}$ & RO \\
\hline \multirow{15}{*}{ Nordeste } & 4 & Consórcio Regional Metropolitano de resíduos sólidos de Alagoas & AL \\
\hline & 5 & $\begin{array}{l}\text { Consórcio Regional de resíduos sólidos do Agreste Alagoano - } \\
\text { CONAGRESTE }\end{array}$ & AL \\
\hline & 6 & $\begin{array}{l}\text { Consórcio Intermunicipal de Desenvolvimento do Norte do Estado de Alagoas } \\
\text { - CONORTE }\end{array}$ & $\mathrm{AL}$ \\
\hline & 7 & Consórcio Intermunicipal do Sul do Estado de Alagoas - CONISUL & $\mathrm{AL}$ \\
\hline & 8 & Consórcio Intermunicipal para Gestão dos Resíduos Sólidos - CIGRES & $\mathrm{AL}$ \\
\hline & 9 & Consórcio Regional de Resíduos Sólidos do Sertão de Alagoas - CRERSSAL & AL \\
\hline & 10 & Consórcio Regional de Resíduos Sólidos da Zona da Mata Alagoana & AL \\
\hline & 11 & $\begin{array}{l}\text { Consórcio COMARES - UCV Consórcio Municipal de Aterro de resíduos } \\
\text { sólidos }\end{array}$ & $\mathrm{CE}$ \\
\hline & 12 & Consórcio Municipal para Aterro de Resíduos Sólidos Pedra Branca & $\mathrm{CE}$ \\
\hline & 13 & Consórcio Municipal para Aterro de Resíduos Sólidos Limoeiro do Norte & $\mathrm{CE}$ \\
\hline & 14 & Consórcio Municipal para Aterro de Resíduos Sólidos Baturité & $\mathrm{CE}$ \\
\hline & 15 & Consórcio Municipal para Aterro de Resíduos Sólidos Sobral & CE \\
\hline & 16 & Consórcio Municipal para Aterro de Resíduos Sólidos Camocim & $\mathrm{CE}$ \\
\hline & 17 & Consórcio Municipal para Aterro de Resíduos Sólidos Pacatuba & $\mathrm{CE}$ \\
\hline & 18 & Consórcio Municipal para Aterro de Resíduos Sólidos São Benedito & $\mathrm{CE}$ \\
\hline
\end{tabular}

\footnotetext{
${ }^{23}$ As fontes das informações foram: Secretaria de Estado de Saneamento, Habitação e Desenvolvimento Urbano - SEDURB do Espírito Santo; Secretaria de Estado e Desenvolvimento Regional, Política Urbana e Gestão Metropolitana - SEDRU de Minas Gerais; Federação Catarinense de Municípios - FECAM; Federação das Associações de Municípios do Rio Grande do Sul - FAMURS; Secretaria de Estado de Saneamento, Habitação e Desenvolvimento Urbano - SEDURB de Pernambuco; Agência Estadual de Meio Ambiente e Recursos Hídricos de Pernambuco - CPRH; Secretaria de Meio Ambiente - SEMAS de Pernambuco; Secretaria Estadual do Ambiente - SEA do Rio de Janeiro; Associação dos Municípios Alagoanos - AMA; Secretaria das Cidades do Ceará; Secretaria de Meio Ambiente e Recursos Hídricos do Rio Grande do Norte; Secretaria de Recursos Hídricos, do Meio Ambiente e da Ciência e Tecnologia de Paraíba; PEGRS de Pernambuco (2012); CEPAM (2014); IPEA (2012); TCU (2011).
} 


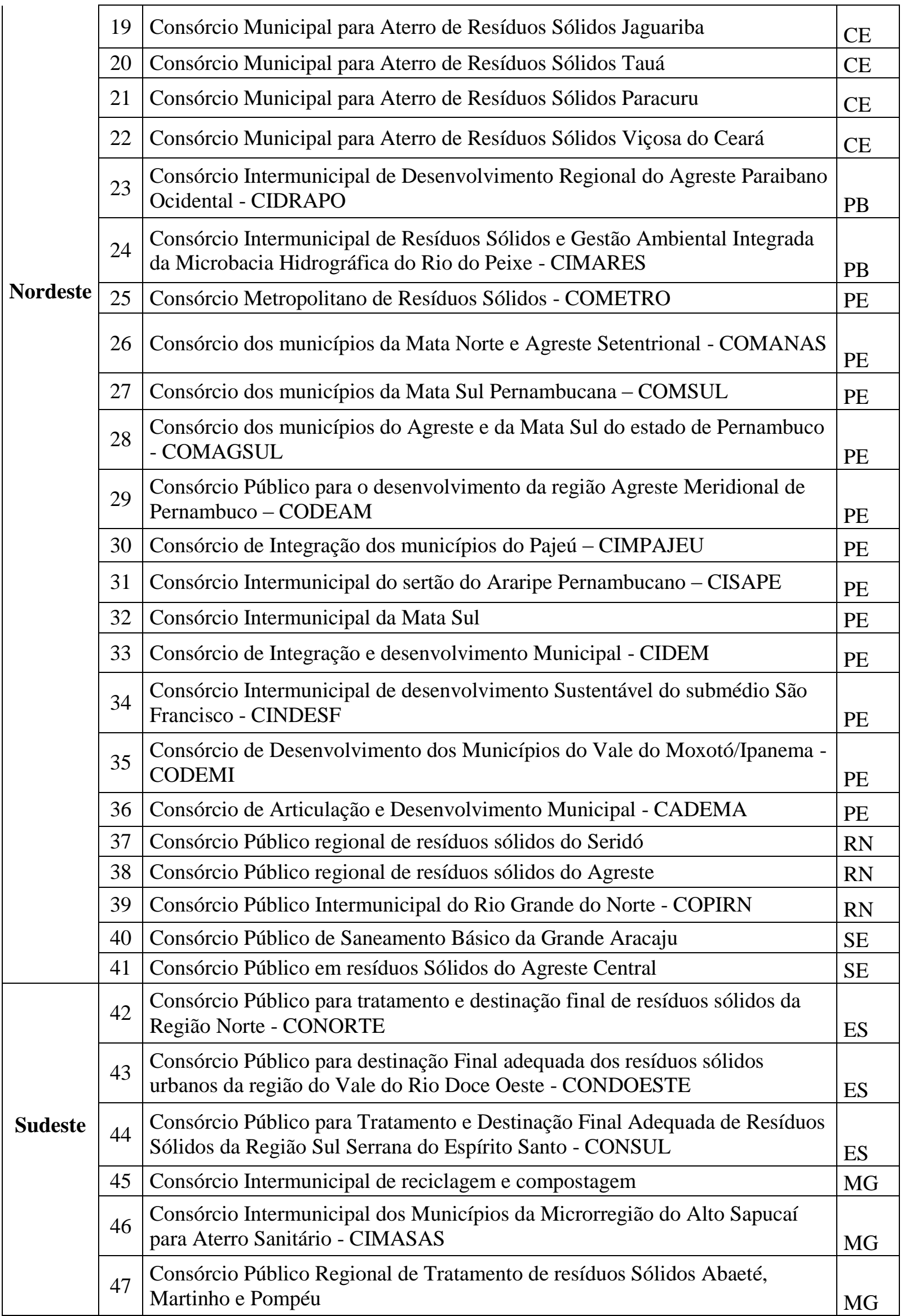




\begin{tabular}{|c|c|c|c|}
\hline \multirow{19}{*}{ Sudeste } & 48 & $\begin{array}{l}\text { Consórcio Médio Paraopebano de resíduos sólidos urbanos } \\
\text { COMPARESOLURB }\end{array}$ & MG \\
\hline & 49 & $\begin{array}{l}\text { Consórcio Intermunicipal dos municípios da Microrregião de Frutal para } \\
\text { aterro sanitário - CIMFAS }\end{array}$ & MG \\
\hline & 50 & $\begin{array}{l}\text { Consórcio Público Intermunicipal de Tratamento de Resíduos Sólidos - } \\
\text { ECOTRES }\end{array}$ & MG \\
\hline & 51 & $\begin{array}{l}\text { Consórcio Intermunicipal do Alto e Médio Carangola para Gestão e Manejo } \\
\text { dos Resíduos Sólidos }\end{array}$ & MG \\
\hline & 52 & Consórcio Público de Gestão de resíduos Sólidos - CPGRS & MG \\
\hline & 53 & Consórcio Público de Gestão de Resíduos Sólidos da Baixada Fluminense & RJ \\
\hline & 54 & Consórcio Público de Gestão de Resíduos Sólidos Lagos 1 & RJ \\
\hline & 55 & Consórcio Público de Gestão de Resíduos Sólidos Centro Sul Fluminense I & RJ \\
\hline & 56 & Consórcio Público de Gestão de Resíduos Sólidos Sul Fluminense 2 & RJ \\
\hline & 57 & Consórcio Público de Gestão de Resíduos Sólidos Vale do Café & RJ \\
\hline & 58 & Consórcio Público de Gestão de Resíduos Sólidos Noroeste & RJ \\
\hline & 59 & Consórcio Público de Gestão de Resíduos Sólidos Serrana 1 & RJ \\
\hline & 60 & Consórcio Público de Gestão de Resíduos Sólidos Serrana 2 & RJ \\
\hline & 61 & Consórcio Intermunicipal para o Aterro Sanitário & SP \\
\hline & 62 & $\begin{array}{l}\text { Consórcio Intermunicipal para Tratamento e Disposição Final do Lixo - } \\
\text { Cotralix }\end{array}$ & SP \\
\hline & 63 & Consórcio Intermunicipal para Gestão de Resíduos Sólidos & SP \\
\hline & 64 & Consórcio Intermunicipal do Aterro Sanitário - Cipas & SP \\
\hline & 65 & $\begin{array}{l}\text { Consórcio Intermunicipal de Manejo de resíduos sólidos da região } \\
\text { metropolitana de Campinas - Consimares }\end{array}$ & SP \\
\hline & 66 & $\begin{array}{l}\text { Consórcio Intermunicipal de Saneamento Básico da região do Circuito das } \\
\text { Aguas - Cisbra }\end{array}$ & SP \\
\hline \multirow{11}{*}{ Sul } & 67 & Consórcio Intermunicipal Caiuá Ambiental - CICA & PR \\
\hline & 68 & Consórcio Intermunicipal para Aterro Sanitário - CIAS & PR \\
\hline & 69 & $\begin{array}{l}\text { Consórcio Intermunicipal de Reciclagem e Compostagem de Lixo - } \\
\text { CONLIXO }\end{array}$ & RS \\
\hline & 70 & $\begin{array}{l}\text { Consórcio Intermunicipal de Tratamento de Resíduos Sólidos Urbanos - } \\
\text { Conitresu }\end{array}$ & RS \\
\hline & 71 & Consórcio Intermunicipal Esmeralda/Pinhal da Serra - Aterro Sanitário & RS \\
\hline & 72 & Consórcio Intermunicipal de Gestão de Resíduos Sólidos - CIGRES & RS \\
\hline & 73 & $\begin{array}{l}\text { Consórcio Intermunicipal de Gerenciamento de Resíduos Sólidos Urbanos - } \\
\text { COMANDAI }\end{array}$ & RS \\
\hline & 74 & $\begin{array}{l}\text { Consórcio Intermunicipal de Resíduos Sólidos Urbanos da Região Sul - } \\
\text { CIRSURES }\end{array}$ & $\mathrm{SC}$ \\
\hline & 75 & Consórcio Intermunicipal do Contestado - COINCO & SC \\
\hline & 76 & Consórcio Intermunicipal do Médio Vale do Itajaí CIMVI & $\mathrm{SC}$ \\
\hline & 77 & Consórcio Intermunicipal de Gerenciamento Ambiental Iberí & $\mathrm{SC}$ \\
\hline
\end{tabular}

Fonte: Elaboração própria, a partir de resultados desta pesquisa. 
Diante da falta de dados disponíveis que mostrassem características, finalidades e especificidades desses Consórcios Públicos, houve a necessidade de gerar novos dados. Para tanto, elaborou-se um questionário com perguntas encaminhadas aos Consórcios. O questionário foi elaborado a partir da base teórica dos capítulos anteriores. Questões levantadas nas entrevistas realizadas com os Fundos e Programas governamentais e as considerações discutidas também foram incorporadas. Para facilitar o preenchimento pelos Consórcios, o questionário foi criado no site Survey Monkey, disponibilizado pelo link: https://pt.surveymonkey.com/s/PesquisaConsorciosRSU. O questionário (Apêndice C) ficou acessível por 30 dias, de 10 de maio de 2014 a 09 de junho de 2014.

Para divulgar o questionário e solicitar seu preenchimento pelos Consórcios, foram enviados e-mails individuais e realizadas ligações telefônicas aos Consórcios identificados, com contatos disponíveis ${ }^{24}$. Muitos Consórcios identificados como existentes, listados no Quadro 10, não possuem dados específicos do Consórcio, ficando suas informações a cargo das Prefeituras, geralmente do município sede. Ao entrar em contato com as Prefeituras, algumas não sabiam informar o nome de um responsável ou não estavam preparadas para responder as perguntas. Com isso, nem todos os Consórcios identificados puderam ser contactados para participar do estudo de caso.

O objetivo da aplicação do questionário foi de conseguir o maior número de respostas para compor a amostra do estudo de caso. A busca pela existência dos Consórcios para GRSU e as solicitações de respostas não privilegiaram nenhum estado ou região, sendo os esforços realizados de maneira equânime. No entanto, alguns estados foram mais participativos do que outros, não significando, porém, que estes estados possuam mais Consórcios. Foram obtidas 29 respostas ao questionário, os dados coletados foram organizados e resumidos com o objetivo de facilitar as análises e as interpretações foram agrupadas em tabelas e gráficos. Com o objetivo de destacar certas características da amostra e auxiliar as interpretações, algumas análises foram realizadas pelo total geral da amostra, por região ou por tipo do Consórcio.

Os Consórcios Públicos que preencheram o questionário e fazem parte do presente estudo de caso estão relacionados no Quadro 11. São oito Consórcios da região Nordeste, quatorze da região Sudeste e sete da região Sul. Dezenove são consórcios intermunicipais e dez são entre municípios e estado, sendo esses localizados todos na região Sudeste.

\footnotetext{
${ }^{24}$ Os cargos dos responsáveis pelo preenchimento do questionário foram: Chefe de Gabinete da Presidência, Gerente Geral, Advogada, Coordenador de Meio Ambiente, Secretário de Meio Ambiente, Diretor de Administração e Finanças, Gerente de Saneamento Básico, Coordenador de Educação Ambiental, Biólogo, Coordenador de Programa, Superintendente, Assessor Técnica.
} 
Quadro 11 - Lista dos Consórcios Públicos participantes do estudo de caso

\begin{tabular}{|c|c|c|c|c|c|}
\hline Região & & Nome do Consórcio Público & $\mathbf{U F}$ & $\begin{array}{l}\text { Tipo do } \\
\text { Consórcio }\end{array}$ & $\begin{array}{l}\text { Quantidade } \\
\text { de } \\
\text { Municípios }\end{array}$ \\
\hline \multirow{8}{*}{ Nordeste } & 1 & $\begin{array}{l}\text { Consórcio Regional de Resíduos Sólidos do } \\
\text { Sertão Alagoano - CRERSSAL }\end{array}$ & $\mathrm{AL}$ & Intermunicipal & 8 \\
\hline & 2 & $\begin{array}{l}\text { Consórcio Intermunicipal de } \\
\text { Desenvolvimento da Região Norte de Alagoas } \\
\text { - Conorte/AL }\end{array}$ & $\mathrm{AL}$ & Intermunicipal & 15 \\
\hline & 3 & $\begin{array}{l}\text { Consórcio Intermunicipal para Gestão dos } \\
\text { Resíduos Sólidos - CIGRES }\end{array}$ & AL & Intermunicipal & 16 \\
\hline & 4 & $\begin{array}{l}\text { Consórcio Intermunicipal do Sul do Estado de } \\
\text { Alagoas - CONISUL }\end{array}$ & $\mathrm{AL}$ & Intermunicipal & 12 \\
\hline & 5 & $\begin{array}{l}\text { Consórcio COMARES - UCV Consórcio } \\
\text { Municipal de Aterro de Resíduos Sólidos }\end{array}$ & $\mathrm{CE}$ & Intermunicipal & 3 \\
\hline & 6 & $\begin{array}{l}\text { Consórcio Intermunicipal Portal da Mata Sul - } \\
\text { Portal Sul Consórcio }\end{array}$ & PE & Intermunicipal & 5 \\
\hline & 7 & $\begin{array}{l}\text { Consórcio Público dos Municípios da Mata } \\
\text { Sul Pernambucana -COMSUL }\end{array}$ & PE & Intermunicipal & 22 \\
\hline & 8 & $\begin{array}{l}\text { Consórcio dos Municípios da Mata Norte e } \\
\text { Agreste Setentrional de Pernambuco - } \\
\text { Comanas }\end{array}$ & $\mathrm{PE}$ & Intermunicipal & 24 \\
\hline \multirow{8}{*}{ Sudeste } & 9 & $\begin{array}{l}\text { Consórcio de Regionalização da Destinação } \\
\text { Final de Resíduos Sólidos Domiciliares dos } \\
\text { Municípios da Região Sul e Serrana - } \\
\text { CONSUL }\end{array}$ & ES & $\begin{array}{l}\text { Municípios e } \\
\text { Estado }\end{array}$ & 28 \\
\hline & 10 & $\begin{array}{l}\text { Consórcio Público de Regionalização da } \\
\text { Destinação Final de Resíduos Sólidos } \\
\text { Domiciliares dos Municípios da Região Doce } \\
\text { Oeste - CONDOESTE }\end{array}$ & ES & $\begin{array}{l}\text { Municípios e } \\
\text { Estado }\end{array}$ & 21 \\
\hline & 11 & $\begin{array}{l}\text { Consórcio de Regionalização da Destinação } \\
\text { Final de Resíduos Sólidos da Região Norte do } \\
\text { ES - CONORTE }\end{array}$ & ES & $\begin{array}{l}\text { Municípios e } \\
\text { Estado }\end{array}$ & 15 \\
\hline & 12 & $\begin{array}{l}\text { Consórcio Intermunicipal de Reciclagem e } \\
\text { Compostagem do Lixo }\end{array}$ & MG & Intermunicipal & 6 \\
\hline & 13 & $\begin{array}{l}\text { Consórcio Público de Gestão de Resíduos } \\
\text { Sólidos da Baixada Fluminense }\end{array}$ & RJ & $\begin{array}{l}\text { Municípios e } \\
\text { Estado }\end{array}$ & 6 \\
\hline & 14 & $\begin{array}{l}\text { Consórcio Público de Gestão de Resíduos } \\
\text { Sólidos Serrana II }\end{array}$ & RJ & $\begin{array}{l}\text { Municípios e } \\
\text { Estado }\end{array}$ & 6 \\
\hline & 15 & $\begin{array}{l}\text { Consórcio Público de Gestão de Resíduos } \\
\text { Sólidos Serrana I }\end{array}$ & RJ & $\begin{array}{l}\text { Municípios e } \\
\text { Estado }\end{array}$ & 4 \\
\hline & 16 & $\begin{array}{l}\text { Consórcio Público de Gestão de Resíduos } \\
\text { Sólidos Noroeste Fluminense }\end{array}$ & RJ & $\begin{array}{l}\text { Municípios e } \\
\text { Estado }\end{array}$ & 15 \\
\hline
\end{tabular}

25 Foi necessário realizar um ajuste nas respostas obtidas pelo Consórcio CONORTE - Consórcio de regionalização da destinação final de resíduos sólidos da região Norte do Espírito Santo, pois se obteve três respostas do Consórcio, sendo duas delas dos municípios e uma do estado. Neste sentido, as três respostas foram consolidadas em uma única resposta. 


\begin{tabular}{|c|c|c|c|c|c|}
\hline \multirow{6}{*}{ Sudeste } & 17 & $\begin{array}{l}\text { Consórcio Público de Gestão de Resíduos } \\
\text { Sólidos Vale do Café }\end{array}$ & RJ & $\begin{array}{l}\text { Municípios e } \\
\text { Estado }\end{array}$ & 4 \\
\hline & 18 & $\begin{array}{l}\text { Consórcio Público de Gestão de Resíduos } \\
\text { Sólidos Sul Fluminense II }\end{array}$ & RJ & $\begin{array}{l}\text { Municípios e } \\
\text { Estado }\end{array}$ & 4 \\
\hline & 19 & $\begin{array}{l}\text { Consórcio Público de Gestão de Resíduos } \\
\text { Centro Sul Fluminense I }\end{array}$ & RJ & $\begin{array}{l}\text { Municípios e } \\
\text { Estado } \\
\end{array}$ & 5 \\
\hline & 20 & $\begin{array}{l}\text { Consórcio Público de Gestão de Resíduos } \\
\text { Lagos I }\end{array}$ & RJ & Intermunicipal & 3 \\
\hline & 21 & $\begin{array}{l}\text { Consórcio Intermunicipal de Saneamento } \\
\text { Básico da Região do Circuito das Águas - } \\
\text { CISBRA }\end{array}$ & SP & Intermunicipal & 12 \\
\hline & 22 & $\begin{array}{l}\text { Consórcio Intermunicipal de Manejo de } \\
\text { Resíduos Sólidos da Região Metropolitana de } \\
\text { Campinas - Consimares }\end{array}$ & SP & Intermunicipal & 8 \\
\hline \multirow{7}{*}{ Sul } & 23 & $\begin{array}{l}\text { Consórcio Intermunicipal Esmeralda Pinhal } \\
\text { da Serra }\end{array}$ & RS & Intermunicipal & 2 \\
\hline & 24 & $\begin{array}{l}\text { Consórcio Intermunicipal de Gestão de } \\
\text { Resíduos Sólidos - CIGRES }\end{array}$ & RS & Intermunicipal & 6 \\
\hline & 25 & $\begin{array}{l}\text { Consórcio Intermunicipal para Aterro } \\
\text { Sanitário - Cias }\end{array}$ & PR & Intermunicipal & 5 \\
\hline & 26 & Consórcio Intermunicipal Caiuá Ambiental & PR & Intermunicipal & 10 \\
\hline & 27 & $\begin{array}{l}\text { Consórcio Intermunicipal do Contestado - } \\
\text { COINCO }\end{array}$ & $\mathrm{SC}$ & Intermunicipal & 9 \\
\hline & 28 & $\begin{array}{l}\text { Consórcio Intermunicipal do Médio Vale do } \\
\text { Itajaí - CIMVI }\end{array}$ & $\mathrm{SC}$ & Intermunicipal & 9 \\
\hline & 29 & $\begin{array}{l}\text { Consórcio Intermunicipal de Gerenciamento } \\
\text { Ambiental Iberí }\end{array}$ & $\mathrm{SC}$ & Intermunicipal & 7 \\
\hline
\end{tabular}

Fonte: Elaboração própria a partir de resultados desta pesquisa.

A dificuldade informacional sobre os Consórcios no Brasil foi explicitada também pelos respondentes de nossa pesquisa. Alguns dos responsáveis pelo preenchimento do questionário pediram nossos contatos de outros Consórcios para que possam trocar experiências e o envio dos resultados da pesquisa desta dissertação ${ }^{26}$.

\subsection{Análise das respostas dos 29 Consórcios Públicos para gestão de resíduos sólidos}

Algumas características municipais são usadas para justificar a formação de Consórcios Públicos como, por exemplo, a quantidade de habitantes, a distância entre os municípios, características locais e necessidades setoriais semelhantes.

26 A relação dos contatos daqueles Consórcios que disponibilizaram essa informação pela resposta no questionário está disponível no Apêndice D. 
O total de municípios integrantes dos 29 Consórcios analisados é 285, sendo 100 da região Nordeste ${ }^{27}, 137$ da Sudeste e 48 da região Sul. Os dados do Gráfico 6 demostram que, para os 29 Consórcios analisados, a formação de Consórcios Públicos tende a se concentrar nos municípios com até 50 mil habitantes ${ }^{28}$, sendo a maioria concentrada nas faixas entre 10.001 a 50.000 habitantes. Na análise por região, os Consórcios da região Sul concentram-se na faixa populacional de até 5 mil habitantes, os das regiões Nordeste na de 20.001 a 50.000 e Sudeste na faixa de 10.001 a 20.000 .

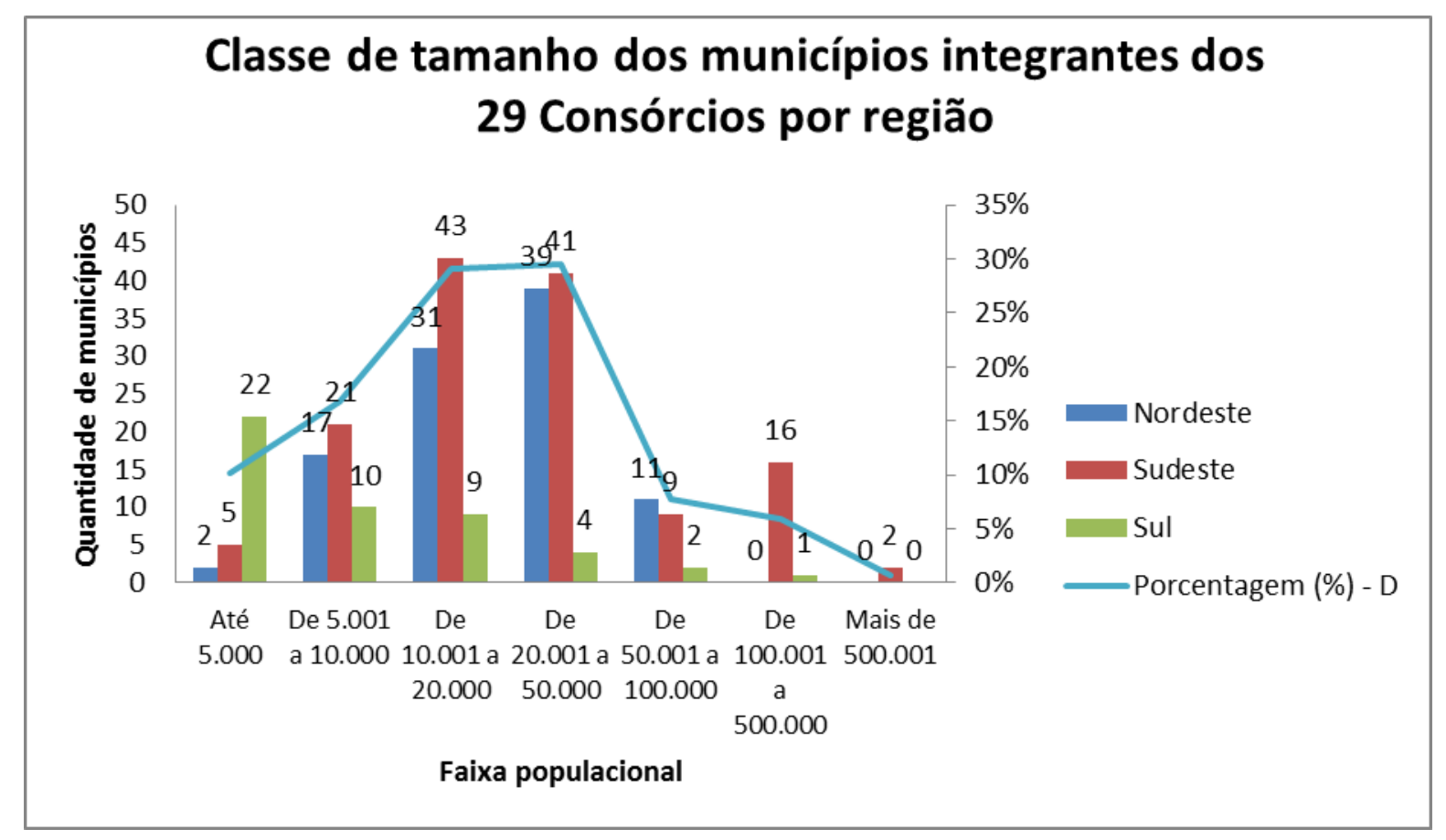

Gráfico 6 - Classe de tamanho dos municípios integrantes dos 29 Consórcios Públicos analisados por região.

Fonte: Elaboração própria, a partir de IBGE, Censo Demográfico 2010 e resultados desta Pesquisa.

Conhecer os motivos que levam os entes federativos a se consorciarem para a realização de uma gestão compartilhada de RSU é um dos primeiros passos para avaliar este instrumento de política pública. Para tanto, o Gráfico 7 apresenta os principais objetivos dos 29 Consórcios Públicos analisados. Nas três regiões, os objetivos principais giram em torno

\footnotetext{
27 Em termos brutos, a soma de municípios da região Nordeste é 105. No entanto, cinco municípios de Pernambuco aparecem em dois Consórcios, o Consórcio Intermunicipal Portal da Mata Sul e Consórcio Público dos Municípios da Mata Sul Pernambucana - COMSUL. Após o recebimento dos 2 questionários, contactou-se o Consórcio Portal da Mata Sul, e este afirmou que os cinco municípios fazem parte apenas deste Consórcio. Para não alterar as respostas e dados obtidos pelo Consórcio COMSUL, foram feitos ajustes nas análises quando necessário.

28 Os dados da população são do Censo Demográfico de 2010 (IBGE, 2010) e todos os dados coletados encontram-se no Apêndice E.
} 
do processo de disposição final, sendo no total $86 \%$ em relação a unidades de disposição final e 69\% para erradicação de lixões e recuperação de áreas degradadas.

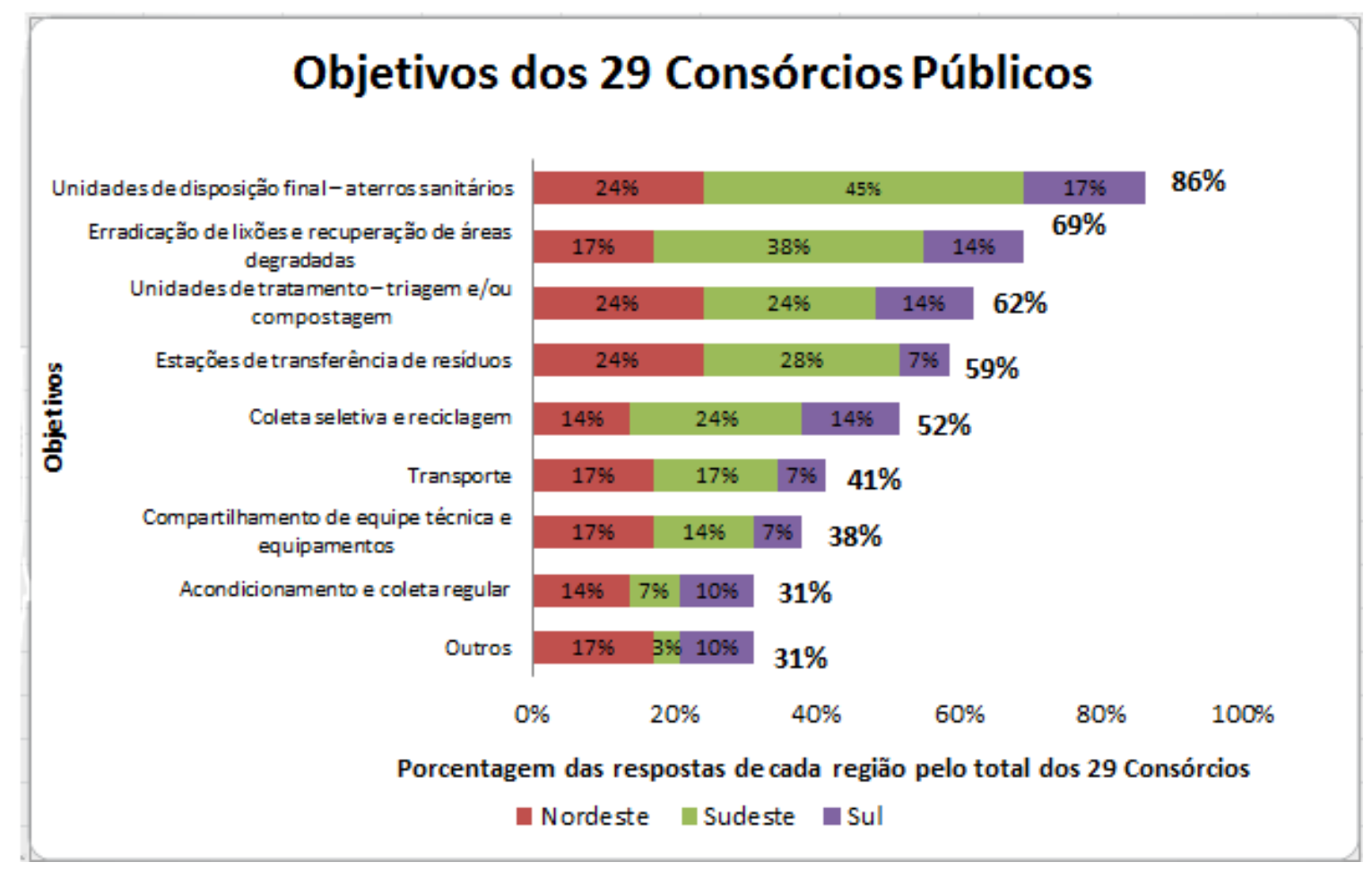

Gráfico 7 - Objetivos relacionados pelos 29 Consórcios Públicos pesquisados.

Fonte: Elaboração própria, a partir de resultados desta Pesquisa.

Um ponto de destaque nos objetivos listados pelos Consórcios foi a porcentagem assinalada como outros objetivos, ou seja, objetivos não relacionados apenas ao setor de RSU. Por exemplo, dos oito Consórcios do Nordeste, dois informaram que trabalham também com Educação Ambiental, um com Saúde e dois como Consórcios Multifinalitários. No Sudeste, o Consórcio da Baixada Fluminense do Rio de Janeiro tem como objetivo adicional a instalação de Unidades de Tratamento de Resíduos da Construção Civil - Ecopontos e Áreas de Triagem e Transbordo. No Sul, também há um Consórcio Multifinalitário, abrangendo as áreas de saneamento básico e ambiental, recursos naturais, cultura, desenvolvimento institucional e turismo; um Consórcio de gerenciamento ambiental, que inclui a questão dos resíduos como um dos objetivos; e outro Consórcio sinalizou que a gestão de resíduos sólidos não será o seu único foco.

Por um lado, os dados apresentados demostram que os municípios têm aproveitado a estrutura institucional do Consórcio Público para atuar em áreas afins municipais, o que pode diminuir os custos administrativos e aumentar a cooperação regional. Por outro lado, a presença de Consórcios multifinalitários dificulta a identificação dos Consórcios com foco 
especial na GRSU, pois ao atuar em diferentes áreas, a sua classificação pode não transmitir de fato as suas atividades e dificultar a avaliação dos seus impactos para a sociedade.

Além de conhecer os objetivos dos Consórcios, faz-se necessário identificar o que levou a sua formação. A Tabela 1 apresenta os resultados dos incentivos para a criação dos 29 Consórcios - pelo total da amostra, por tipo do Consórcio e por região geográfica. Os pontos principais referem-se à necessidade de cumprir a regulamentação estipulada pela PNRS, a carência de recursos financeiros municipais individuais e a presença de lixões nos municípios, variando pouco de um para outro.

Tabela 1 - Incentivos à formação dos 29 Consórcios Públicos pesquisados pelo total da amostra, por tipo e por região geográfica

\begin{tabular}{|c|c|c|c|c|c|c|c|}
\hline & & $\begin{array}{c}\text { Necessidade } \\
\text { de } \\
\text { cumprimento } \\
\text { da PNRS }\end{array}$ & $\begin{array}{c}\text { Carência de } \\
\text { recursos } \\
\text { financeiros } \\
\text { municipais } \\
\text { individuais }\end{array}$ & $\begin{array}{l}\text { Presença de } \\
\text { lixões nos } \\
\text { Municípios }\end{array}$ & $\begin{array}{c}\text { Carência de } \\
\text { recursos } \\
\text { humanos/ } \\
\text { técnicos } \\
\text { municipais } \\
\text { individuais }\end{array}$ & $\begin{array}{c}\text { Possibilidade } \\
\text { de priorização } \\
\text { no acesso a } \\
\text { recursos da } \\
\text { União }\end{array}$ & $\begin{array}{c}\text { Escassez de } \\
\text { área } \\
\text { disponível } \\
\text { para } \\
\text { implantação } \\
\text { aterros } \\
\text { sanitários }\end{array}$ \\
\hline $\begin{array}{c}\text { Total } \\
\text { da } \\
\text { amostra }\end{array}$ & $\begin{array}{l}(29) \\
\text { Consórcios } \\
\end{array}$ & $86 \%$ & $83 \%$ & $79 \%$ & $55 \%$ & $28 \%$ & $24 \%$ \\
\hline 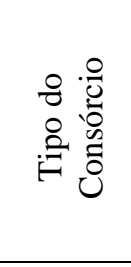 & $\begin{array}{l}\text { Município e } \\
\text { Estado } \\
\text { verticais (10) } \\
\text { Intermunicipal } \\
\text { - horizontais (19) }\end{array}$ & $100 \%$ & $100 \%$ & 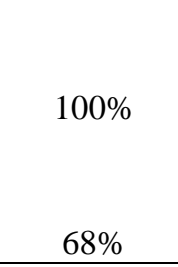 & $42 \%$ & $37 \%$ & $21 \%$ \\
\hline 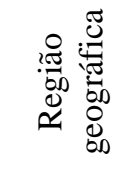 & $\begin{array}{l}\text { Nordeste (8) } \\
\text { Sudeste (14) } \\
\text { Sul (7) }\end{array}$ & $\begin{array}{c}88 \% \\
100 \% \\
57 \%\end{array}$ & $\begin{array}{c}75 \% \\
100 \% \\
57 \%\end{array}$ & $\begin{array}{l}63 \% \\
93 \% \\
71 \%\end{array}$ & $\begin{array}{c}63 \% \\
79 \% \\
0 \%\end{array}$ & $\begin{array}{l}50 \% \\
21 \% \\
14 \%\end{array}$ & $\begin{array}{l}13 \% \\
36 \% \\
14 \%\end{array}$ \\
\hline
\end{tabular}

Fonte: Elaboração própria, a partir de resultados desta Pesquisa.

A preocupação dos municípios com as normas impostas pela PNRS é comprovada pelo objetivo dominante ser a disposição final correta dos resíduos sólidos. Para os Consórcios da região Sul, o maior incentivo para formação de Consórcios é a presença de lixões nos Municípios. Levando em consideração que a PNRS estipula uma data para o encerramento dos lixões ${ }^{29}$, identifica-se a influência da PNRS neste ponto também.

\footnotetext{
${ }^{29}$ O prazo para o encerramento dos lixões, de acordo com a Lei, terminou em 03 de Agosto de 2014. O Poder Executivo vetou trecho da Medida Provisória 651 que previa a prorrogação em quatro anos do prazo. Os municípios que não cumpriram a lei estão sujeitos a ações civis públicas, multas e os gestores podem ser processados por improbidade administrativa. No entanto, o governo federal está em articulação com o Ministério Público Federal para estabelecer uma estratégia de negociação dos prazos de encerramento dos lixões por meio de Termos de Ajustamento de Conduta com as prefeituras (MMA, 2014g).
} 
Questões econômicas e financeiras são justificativas para a junção de municípios na busca de uma gestão compartilhada setorial. A carência de recursos financeiros municipais individuais foi apontada como incentivo para a criação do Consórcio em um total de $83 \%$ das respostas; sendo de $88 \%$ e $100 \%$ para as regiões Nordeste e Sudeste, respectivamente. Tais questões serão aprofundadas na continuação do presente texto.

Uma hipótese inicial do presente estudo era a de que a possibilidade de priorização no acesso a recursos da União ou incentivos instituídos pelo Governo Federal para os Municípios integrantes de Consórcios Públicos, presente na PNRS, seria um motivo significante para a formação de Consórcios, pois os municípios teriam priorização no acesso aos recursos para investir na GRSU. Pela tabela 1, 28\% (8) Consórcios sinalizaram a priorização no acesso a recursos como incentivo para formação dos Consórcios, com destaque para a região Nordeste com 50\%. Desses oito Consórcios, seis foram criados após a PNRS $^{30}$ e apenas dois foram criados antes de 2010, ano da criação da PNRS, sendo que em um deles o Consórcio Intermunicipal de Reciclagem e Compostagem do Lixo de Minas Gerais, criado em 2004, ressaltou mudanças na constituição do Consórcio para poder ter acesso a recursos da União. Pelo exposto, atesta-se a influência da PNRS e a relevância desse quesito para a formação dos Consórcios.

Os especialistas entrevistados do FNMA e Funasa e as conclusões da Auditoria do TCU (2011) destacaram a carência de recursos técnicos municipais como uma das principais dificuldades dos municípios em realizar os PGIRS e apresentarem proposta aos Fundos para acesso a recursos. Os dados dos Consórcios pesquisados mostram que a carência de recursos humanos/técnicos municipais é um incentivo forte para a formação dos Consórcios das regiões Sudeste $(79 \%)$ e Nordeste $(63 \%)$. Todavia, na região Sul, a carência técnica não é um ponto relevante para nenhum dos Consórcios analisados, diferenciando-a das demais regiões. Neste caso, presume-se que projetos de capacitação técnica para as regiões Nordeste e Sudeste seriam mais relevantes e eficazes do que para a região Sul ou que esta região não demandaria treinamento adicional.

Os Consórcios entre municípios e estado beneficiam-se do apoio técnico oferecido por este, como ente consorciado, por meio das Secretarias Ambientais, sendo isso apontado pelos Consórcios como um ponto adicional de estímulo para a formação desse tipo de Consórcio. $\mathrm{O}$ papel estadual para este tipo de Consórcio também é forte no quesito apoio financeiro, institucional e de regulação.

\footnotetext{
${ }^{30}$ A lei da PNRS foi sancionada em agosto de 2010, logo os Consórcios formados até 2009 foram considerados como antes da PNRS e os Consórcios formados a partir de 2010 como depois da PNRS.
} 
Já para os Consórcios Intermunicipais, a participação estadual é maior na parte de fiscalização, que pode caracterizar atividades de acompanhamento, monitoramento, controle ou avaliação. Já a participação estadual na fiscalização para os Consórcios verticais é nula, uma vez que o estado é um ente consorciado e, sendo firmado Contrato de Programa, o Consórcio não pode regular e fiscalizar os serviços que ele próprio fornece.

Um dos Consórcios informou que o papel do estado era o desenvolvimento do PEGIRS. Além disso, o Consórcio pode ter como um dos seus objetivos a elaboração do PIGRS como, por exemplo, o Consórcio CRERSSAL de Alagoas, que informou que está concluindo o Plano para iniciar a operação do Consórcio.

Muitos municípios brasileiros, aproximadamente 65\% (IBGE, 2014a), ainda não possuem seu PGIRS. Este fato foi corroborado pelas respostas dos 29 Consórcios analisados. Doze deles informaram não possuir nenhum dos Planos, apenas sete assinalaram possuir o PMGIRS e quatro o PIGRS. Os demais não responderam. Esse problema também foi constatado pelo FNMA e pela Funasa, que afirmaram que a falta dos Planos é a maior causa dos municípios não conseguirem aprovação das propostas submetidas, uma vez que sua existência é critério obrigatório.

Para os Consórcios, a falta de Planos pode demandar mais esforços e recursos nas etapas de formação, pois várias etapas iniciais que deveriam fazer parte da constituição dos Consórcios fazem parte do PGIRS, como: realização de estudos de viabilidade econômicofinanceiro, ambientais e sociais, territoriais e diagnósticos sobre a geração de resíduos.

Neste sentido, além da carência de recursos humanos/técnicos, a carência de recursos financeiros pode ser uma das justificativas para esta lacuna, apoiando as conclusões da Auditoria do TCU (2011) ao informar que financiamentos e convênios precisam ser estabelecidos para a criação dos Planos, pois são peça fundamental na GRSU e irão influenciar a eficácia e eficiência das atividades e instrumentos aplicados.

A formação e a implementação de um Consórcio Público podem ser melhor compreendidas por meio da associação das etapas necessárias à criação dos consórcios estudados às etapas de políticas públicas sugeridas por Roura (1997). Com esse intuito, chamaremos de primeira fase o conjunto de reconhecimento, análise, desenho e consultas. Já a segunda fase seria composta de discussão e execução da política, as etapas determinadas pela LCP. Neste sentido, o Gráfico 8 e o Quadro 12 apresentam os resultados das etapas da primeira fase realizadas pelos 29 Consórcios pesquisados para a formação do Consórcio. 
Quadro 12 - Aplicação desejável e resultados observados das etapas de Primeira Fase dos 29 Consórcios

\begin{tabular}{|c|c|c|c|}
\hline & Etapas & Aplicacão Desejável & Resultados observados \\
\hline \multirow{4}{*}{ 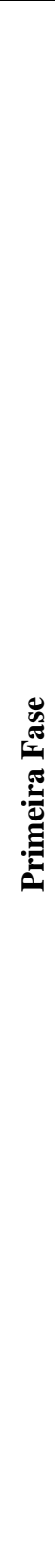 } & Reconhecimento & $\begin{array}{l}\text { Captação de informações sobre } \\
\text { a geração de RSU de cada } \\
\text { município, quantidade e } \\
\text { composição, ou seja, o } \\
\text { diagnóstico da geração, da } \\
\text { situação de coleta, transporte, } \\
\text { tratamento e disposição final da } \\
\text { região dos entes consorciados. }\end{array}$ & $\begin{array}{l}\text { Pouco mais da metade dos } 29 \\
\text { Consórcios efetuaram um diagnóstico da } \\
\text { geração de RSU de cada município } \\
\text { consorciado. Todavia, no recorte por } \\
\text { região, a região Sul destaca-se com mais } \\
\text { de } 80 \% \text { de realização. }\end{array}$ \\
\hline & Análise & $\begin{array}{l}\text { Estudos de viabilidade } \\
\text { econômico-financeira do } \\
\text { Consórcio e os estudos } \\
\text { ambientais e sociais dos danos } \\
\text { causados pela falta ou por } \\
\text { formas incorretas de GRSU. } \\
\text { Além dos estudos territoriais, } \\
\text { ocupação do uso do solo e } \\
\text { distância entre os municípios. }\end{array}$ & $\begin{array}{l}\text { Dos } 29 \text { Consórcios, menos de } 40 \% \\
\text { realizaram ambos os estudos. Todavia, } \\
\text { na análise por região, a região Nordeste } \\
\text { destaca-se com } 63 \% \text { nos estudos de } \\
\text { viabilidade econômico-financeira, mas } \\
\text { nos estudos de impactos ambientais e } \\
\text { sociais sua participação é abaixo dos } \\
40 \% \text {. } \\
\text { Dos } 29 \text { Consórcios, apenas a metade } \\
\text { realizou estudos territoriais, de uso e } \\
\text { ocupação do solo e de distância entre os } \\
\text { munícipios. }\end{array}$ \\
\hline & Desenho & $\begin{array}{l}\text { Pode ser considerado como os } \\
\text { PMGIRS ou PIGRS }\end{array}$ & $\begin{array}{l}12 \text { Consórcios informaram não possuir } \\
\text { nenhum dos Planos, apenas } 7 \\
\text { assinalaram possuir o PMGIRS e } 4 \text { o } \\
\text { PIGRS. Os demais não responderam. }\end{array}$ \\
\hline & Consultas & $\begin{array}{l}\text { Consultas e envolvimento das } \\
\text { partes interessadas: Órgão de } \\
\text { limpeza municipal; ONGs do } \\
\text { setor RSU; comunidades } \\
\text { vizinhas aos aterros sanitários; } \\
\text { população do município sede; } \\
\text { empresas do setor; cooperativas } \\
\text { de catadores de materiais } \\
\text { recicláveis. Além de grupos de } \\
\text { interesses: Secretarias Estaduais } \\
\text { e/ou Municipais das Cidades, } \\
\text { Meio Ambiente, Planejamento } \\
\text { Urbano, Saúde, Saneamento, } \\
\text { Câmaras Municipais. }\end{array}$ & $\begin{array}{l}\text { Dos } 29 \text { Consórcios, apenas } 30 \% \\
\text { realizaram consultas e envolveram as } \\
\text { partes interessadas no processo de } \\
\text { formação do Consórcio e metade } \\
\text { consultaram as Secretarias que de } \\
\text { alguma forma possuem atividades } \\
\text { relacionadas à GRSU. }\end{array}$ \\
\hline
\end{tabular}

Fonte: Elaboração própria, a partir de resultados desta Pesquisa. 


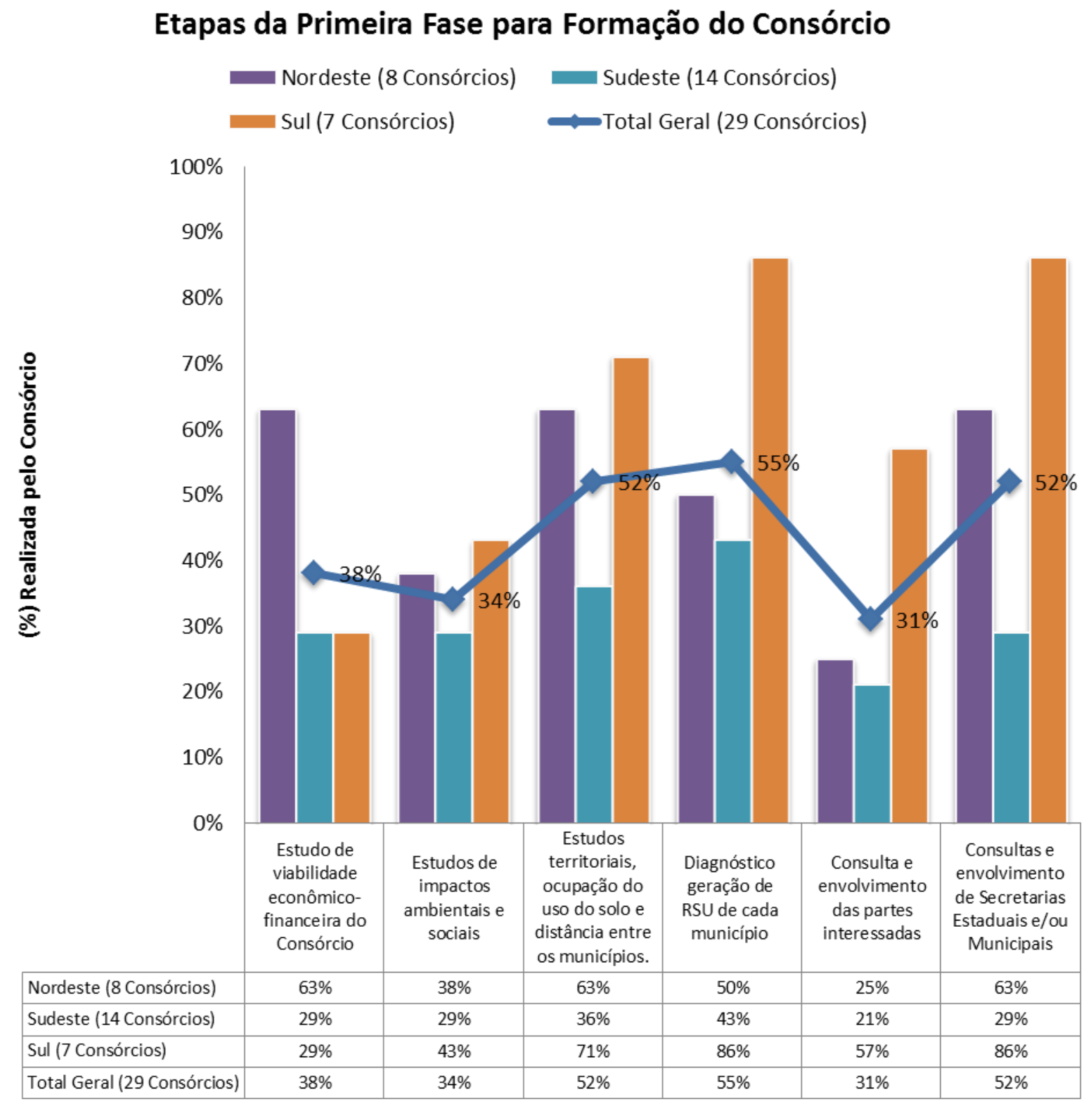

Gráfico 8 - Etapas da Primeira Fase para a formação dos 29 Consórcios Públicos Fonte: Elaboração própria, a partir de resultados desta Pesquisa.

Levando em consideração que o objetivo majoritário dos 29 Consórcios é a disposição final de resíduos sólidos e, consequentemente, a construção de aterros sanitários, merece maior atenção a baixa proporção de estudos territoriais, de ocupação do uso do solo e distância entre os municípios nas respostas dos 29 Consórcios. Os dados obtidos poderiam ser justificados se os municípios já possuíssem PIGRS, com esses estudos já realizados, mas levando em consideração a baixa porcentagem dos que informaram possuir um dos PGIRS, presume-se que essa não seja a justificativa. Dados dos IBGE (2014a) confirmam que a ausência dessas análises é uma realidade dominante nos municípios brasileiros ao constatar 
que apenas $1.742(31,27 \%)$ dos municípios possuem legislação específica sobre zoneamento ou uso e ocupação do solo. Tal fato pode impossibilitar o planejamento da construção de aterros sanitários regionais e compartilhados.

No caso dos Consórcios Públicos que decidem por um aterro compartilhado, os custos de transporte precisam ser levados em consideração, uma vez que os aterros sanitários são localizados em outro município. Precisa-se calcular os custos de transporte até o aterro e avaliar a necessidade de se construir estações de transferência. Os custos com o transporte consideram condições das estradas e rodovias, depreciação, seguro e manutenção dos caminhões, combustível e mão de obra (PORTER, 2002). Além disso, a quantidade de resíduos gerados e a implantação de sistema de coleta seletiva também impactam o custo, uma vez que a coleta seletiva reduz a quantidade de resíduos encaminhados ao aterro sanitário. Destaca-se ainda que a distância ótima de transporte de resíduos a um aterro sanitário é definida pelos custos da terra e pelos custos de transporte ${ }^{31}$.

Nos 29 Consórcios estudados, não houve perguntas diretas sobre a construção ou operação de aterros. No entanto, como o objetivo majoritário dos consórcios é a disposição dos resíduos, conclui-se que a avaliação da localização do aterro é fundamental por seu impacto nos custos. Embora não seja possível aprofundar esta discussão por falta de dados, pela heterogeneidade da localização regional e pela quantidade de municípios dos 29 Consórcios pesquisados, destaca-se a relevância do planejamento desses pontos durante as etapas de formação do Consórcio.

A segunda fase, apresentada no Gráfico 9 e Quadro 13, retrata as fases de discussão e execução ${ }^{32}$. Destaca-se que as aplicações desta fase são as determinadas pela Lei de Consórcios Públicos - LCP. Em vista disso, nota-se pelo Gráfico 9 uma porcentagem maior de conclusão pelos Consórcios pesquisados das etapas de elaboração e assinatura do Protocolo de Intenções, de ratificação do Protocolo de Intenções, da convocação da Assembleia Geral, da aprovação do Estatuto e do início das atividades do que das etapas da primeira fase não determinadas por Lei (Gráfico 8).

A demora ou ausência da realização das etapas de primeira fase pode impactar no tempo de conclusão das etapas de segunda fase. Tomando como exemplo os Consórcios pesquisados que ainda não estão em operação, e constatado pelas respostas que sua maioria

\footnotetext{
${ }^{31}$ No ponto ótimo, o declínio marginal no preço da terra se iguala ao aumento marginal no custo do transporte. Logo, qualquer alteração quer no preço dos terrenos ou nos custos de transporte influencia a localização ótima do aterro sanitário (PORTER, p. 103, 2002).

${ }^{32} \mathrm{O}$ presente estudo propõe a divisão de primeira e segunda fase para a explicação da formação e implementação de Consórcios Públicos, as etapas de cada fase são baseadas nas etapas de políticas públicas sugeridas por ROURA (1997).
} 
começou a elaboração do Protocolo de Intenções entre os anos de 2009 e 2010. Caso, estes Consórcios entrem em operação em 2014, eles demoraram de quatro a cinco anos entre a primeira fase de discussão a última da execução.

Os Consórcios pesquisados assinalaram algumas justificativas para a não operação: fase de conclusão do PIGRS, ou em fase de aprovação do Estatuto ou atraso na elaboração dos projetos executivos. Não foram realizadas perguntas diretas sobre as etapas de monitoramento, avaliação e divulgação, mas destaca-se que elas estão contidas na etapa de execução, e precisam estar presentes em todas as outras fases de formulação dos Consórcios para possibilitar que novas ações sejam tomadas no decorrer do processo.

\section{Quadro 13 - Aplicação desejável e resultados observados das etapas de Segunda Fase dos 29 Consórcios}

\begin{tabular}{|c|c|c|c|}
\hline & Etapas & Aplicação desejável & Resultados observados \\
\hline \multirow{2}{*}{ 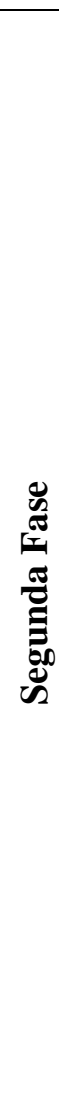 } & Discussão & $\begin{array}{l}\text { 1. O Protocolo de Intenções } \\
\text { do Consórcio pode ser } \\
\text { considerado o primeiro } \\
\text { passo da etapa de discussão. } \\
\text { 2. Ratificação do Protocolo } \\
\text { de Intenções nas Câmaras } \\
\text { Legislativas; } \\
\text { 3. Convocação e aprovação } \\
\text { do Estatuto pela } \\
\text { Assembleia Geral e } \\
\text { publicação na Imprensa } \\
\text { Oficial. }\end{array}$ & $\begin{array}{l}\text { A elaboração do Protocolo de Intenções dos } 29 \\
\text { Consórcios foi realizada entre os anos de } 1998 \text { a } \\
2013 \text { e a maioria dos Consórcios a concluiu. } \\
\text { Ressalta-se, no entanto, que a LCP é do ano de } \\
2005 \text {, fato que pode justificar a não sinalização de } \\
\text { sua conclusão pelos Consórcios formados } \\
\text { anteriormente a esta data. } \\
\text { Os } 29 \text { Consórcios apresentaram uma elevada } \\
\text { porcentagem de realização das etapas de ratificação } \\
\text { e aprovação do Estatuto. } \\
\text { Entre a elaboração do Protocolo e a ratificação, os } \\
\text { Consórcios assinalaram sua realização ambos no } \\
\text { mesmo ano ou em até } 2 \text { anos da data da elaboração. }\end{array}$ \\
\hline & Execução & $\begin{array}{l}\text { 1. Início das atividades; } \\
\text { 2. Operação do Consórcio - } \\
\text { implementação } \\
\text { propriamente dita das } \\
\text { atividades do Consórcio. }\end{array}$ & $\begin{array}{l}\text { Dos } 29 \text { Consórcios, } 93 \% \text { assinalaram que possuem } \\
\text { o Protocolo de Intenções contra apenas } 31 \% \text { que } \\
\text { estão em operação. } \\
\text { Os Consórcios que não estão operando começaram } \\
\text { com a elaboração do Protocolo de Intenções entre } \\
\text { os anos de } 2007 \text { a } 2013 \text {, sendo a maioria entre os } \\
\text { anos de } 2009 \text { e } 2010 \text {. Tomando como base a } \\
\text { maioria, caso estes Consórcios operem no ano de } \\
\text { 2014, eles demoraram de quatro a cinco anos entre } \\
\text { a primeira etapa da fase de discussão a última da } \\
\text { execução. }\end{array}$ \\
\hline
\end{tabular}

Fonte: Elaboração própria, a partir de resultados desta pesquisa. 


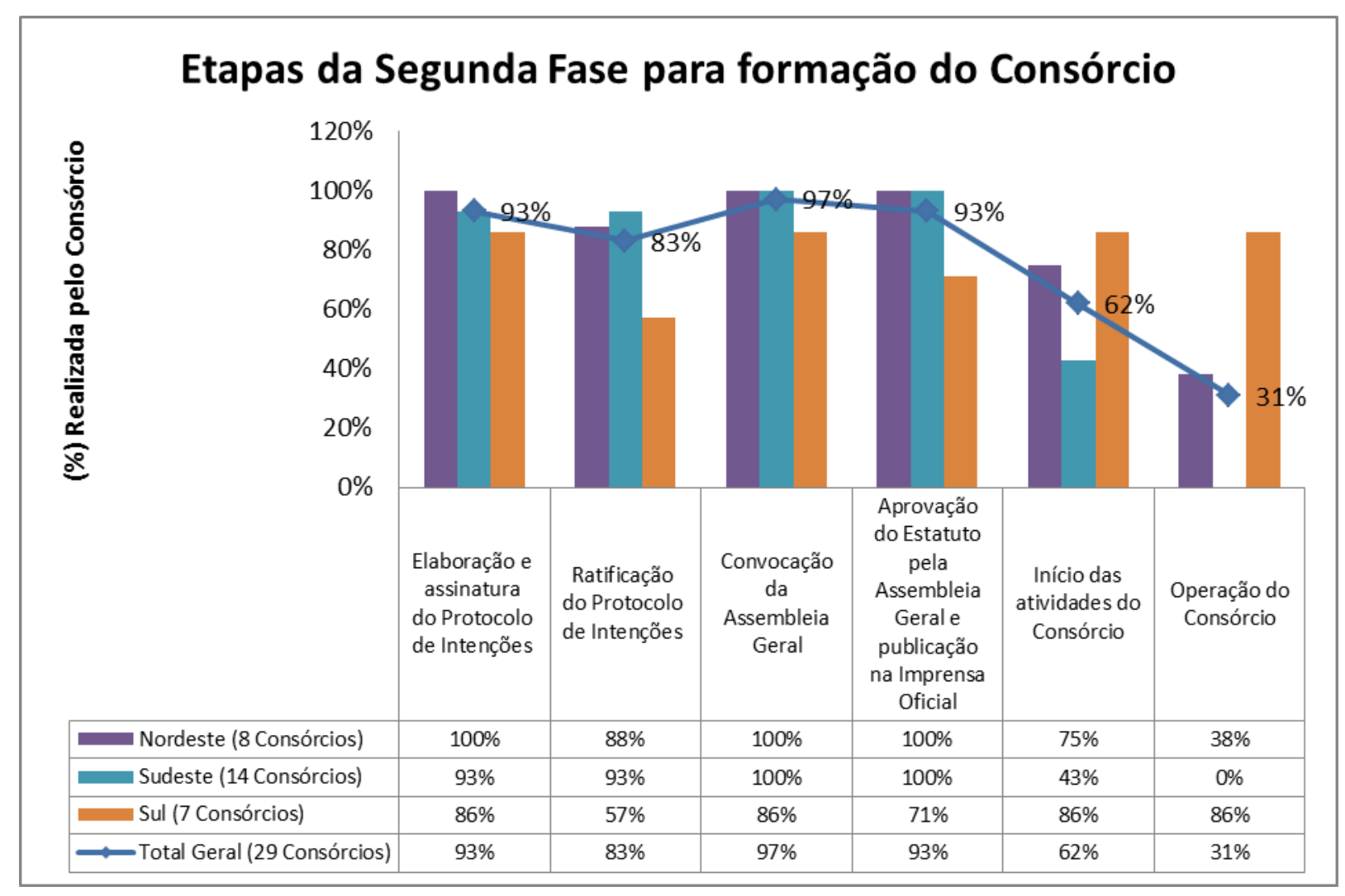

Gráfico 9 - Etapas da Segunda Fase para a formação dos 29 Consórcios

Fonte: Elaboração própria, a partir de resultados desta pesquisa.

As responsabilidades da prestação dos serviços de coleta, transporte, triagem, tratamento e disposição final precisam ser bem definidos, pois podem ou não ser feitas pelo Consórcio e interferem no planejamento e nos custos envolvidos. Neste sentido, no questionário aplicado aos Consórcios foi solicitado que as atividades executadas fossem correlacionadas com os entes responsáveis pela execução (Gráfico 10).

Constata-se que as Prefeituras ainda detêm a maior parte da responsabilidade em todas as atividades consideradas e que os serviços de coleta regular, seletiva e transporte são os mais centralizados nas Prefeituras. Os dados da disposição são os mais diversificados, podendo-se pressupor que é a etapa no processo de gestão com maior possibilidade de cooperação. Além disso, os dados reforçam as informações de respostas anteriores, comprovando a tendência da participação maior dos Consórcios na fase de disposição final no manejo de RSU.

Entre as formas que o Consórcio Público pode prestar os serviços, o contrato de programa é o mais presente, seguido pela concessão e, por último, pelas parcerias públicoprivadas (PPP). Todavia, nas observações assinaladas pelos Consórcios, a forma de concessão parece ficar mais presente como tipo de prestação dos serviços pelos Consórcios. A exemplo 
disso, destaca-se quatro Consórcios da região Sudeste que assinalaram a prestação dos serviços por Contrato de Programa, mas informaram que estão em processo de licitação para concessão da construção e operação de aterros sanitários regionais e estações de transferências.

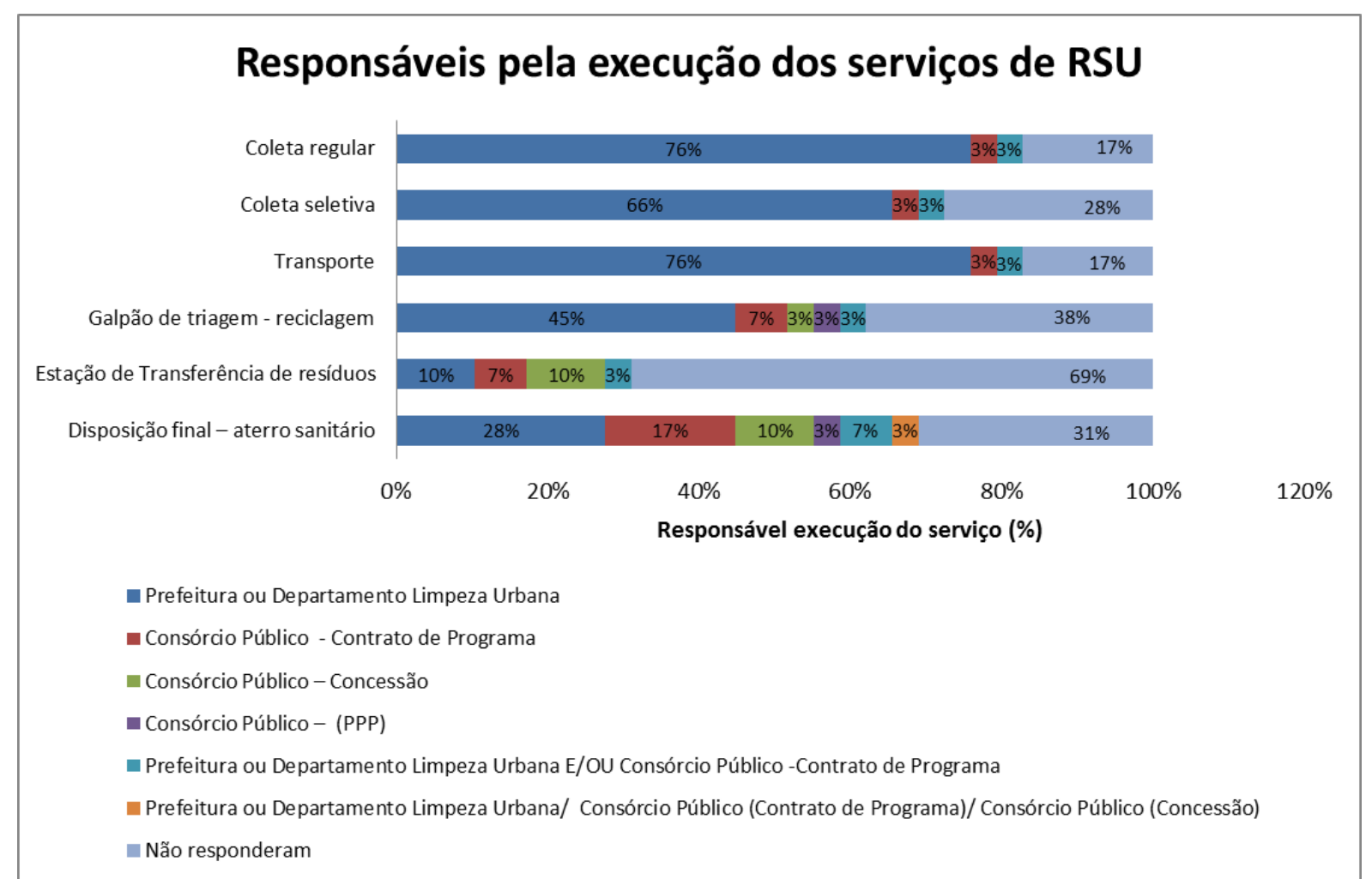

Gráfico 10 - Responsabilidade da execução das atividades de GRSU dos 29 Consórcios pesquisados.

Fonte: Elaboração própria, a partir de resultados desta pesquisa.

Independentemente do tipo de prestação de serviço, os Consórcios precisam de recursos financeiros para desenvolver as atividades e cumprir os contratos firmados. Apenas 12 Consórcios responderam ter tido algum tipo de acesso a recursos, os outros não responderam ou não tiveram nenhum, como aponta o Gráfico $11^{33}$. Observa-se nas respostas a participação do FNMA e da FUNASA, tratados no capítulo anterior.

\footnotetext{
${ }^{33}$ O Gráfico 11 aponta a resposta de 12 dos 29 Consórcios pesquisados. No entanto, possui 13 respostas, pois o Consórcio Intermunicipal para Gestão de resíduos sólidos de Alagoas respondeu duas opções, acesso a Fundos Estaduais e Programas do Governo Federal.
} 


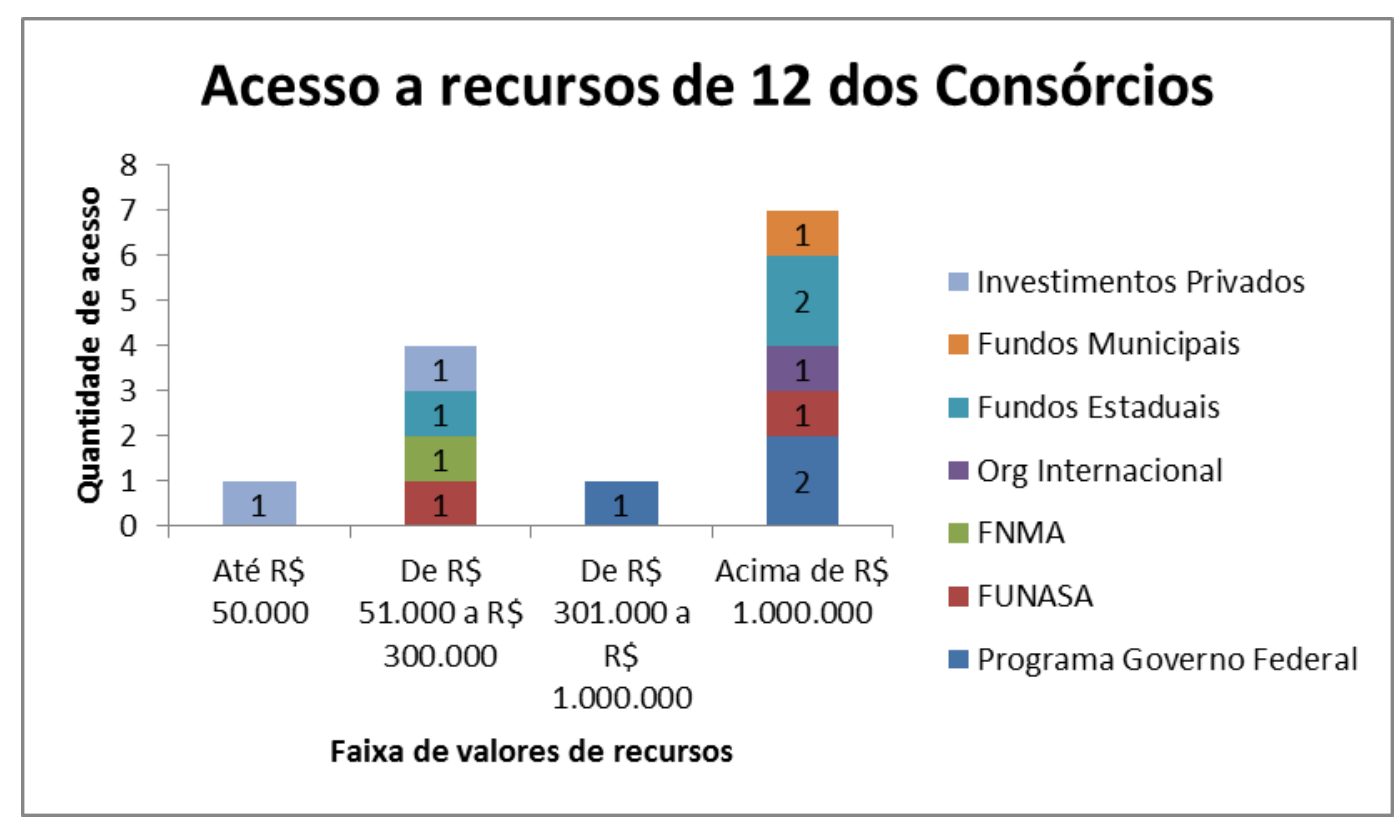

Gráfico 11 - Acesso a recursos (resposta de 12 Consórcios).

Fonte: Elaboração própria, a partir de resultados desta pesquisa.

Das doze respostas obtidas, chama atenção o fato de a maioria dos acessos estarem na faixa acima de $\mathrm{R} \$ 1$ milhão de reais. Embora apenas doze tenham respondido o tipo de recurso a que já tiveram acesso, 22 Consórcios assinalaram a finalidade com que usaram os recursos (Quadro 14). Os recursos foram, na sua maioria, usados para as atividades de disposição final, relacionadas principalmente aos aterros sanitários, sua construção, infraestrutura para implantação, operação, equipamentos e manutenção. Isso demonstra que a disposição final aparece novamente como alvo dos Consórcios e que os recursos são usados também para realização de etapas da primeira fase, como a elaboração do PIGRS e estudos de viabilidade econômico-financeira, territoriais e diagnósticos dos RSU municipais.

Os Consórcios também podem aproveitar oportunidades de mercado, como o Consórcio Intermunicipal Esmeralda/Pinhal da Serra do Rio Grande do Sul, que indicou que obtém recursos advindos da venda com o material reciclado recolhido. O Consórcio COMSUL de Pernambuco informou que não obteve recursos por meio de convênios ou contrato de repasse, distinguindo que, para realizar os serviços requeridos pelos municípios, o Consórcio celebra contrato de Programa com os mesmos, uma vez que o contrato de rateio garante apenas a cobertura dos custos de infraestrutura do Consórcio. 


Quadro 14 - Finalidade dos recursos recebidos por 22 Consórcios
\begin{tabular}{|c|c|}
\hline Finalidade dos recursos externos recebidos pelo Consórcio & $\begin{array}{c}\text { Quantidade de } \\
\text { Consórcios }\end{array}$ \\
\hline Elaboração do Plano Intermunicipal de Resíduos Sólidos; & 2 \\
\hline $\begin{array}{c}\text { Elaboração de estudos: viabilidade econômico-financeira do } \\
\text { Consórcio; impactos ambientais e sociais; territoriais, ocupação do uso } \\
\text { do solo e distância entre os municípios; de informações sobre a } \\
\text { geração de resíduos sólidos urbanos de cada município (quantidade e } \\
\text { composição); }\end{array}$ & 4 \\
\hline Coleta e Transporte (veículos e equipamentos); & 4 \\
\hline $\begin{array}{c}\text { Destinação (Infraestrutura de estações de transferência; Galpão de } \\
\text { triagem para recuperação de recicláveis; Pátio de compostagem; } \\
\text { Equipamentos); }\end{array}$ & 4 \\
\hline $\begin{array}{c}\text { Disposição Final - aterro sanitário (Construção - infraestrutura para } \\
\text { implantação; Operação - equipamentos; Manutenção). }\end{array}$ & 8 \\
\hline
\end{tabular}

Fonte: Elaboração própria, a partir de resultados desta pesquisa.

As respostas dos 29 Consórcios indicam que a prefeitura é a maior fonte de recursos dos processos de varrição e limpeza, coleta regular, coleta seletiva, transporte e construção de galpão para triagem para recuperação de materiais recicláveis ou pátio de compostagem. Os contratos do Consórcio aparecem com maior fonte de recursos para a construção, operação e manutenção dos aterros sanitários. Além disso, apenas um Consórcio assinalou a cobrança pela prestação de serviço e outro a utilização de ICMS Ecológico.

A limitação dos recursos financeiros é apontada como o maior desafio para a manutenção da prestação de serviço dos 29 Consórcios (Gráfico $12^{34}$ ), corroborando o fato de este ser um dos maiores incentivos para a formação dos Consórcios analisados. Neste sentido, chama-se a atenção para a importância dos Consórcios agregarem outras fontes de recursos e implantar a arrecadação de tributos pela prestação dos serviços de RSU para garantir a manutenção dos serviços. A dificuldade de estabelecimento de cobrança de tributos que possam cobrir os gastos com os serviços foi assinalada como um desafio para metade dos Consórcios e, no recorte por região, destacou-se na região Sudeste.

\footnotetext{
${ }^{34} \mathrm{Na}$ representação gráfica (Gráfico 12), com intuito de facilitar a análise dos dados, dois Consórcios foram retirados por serem considerados outliers, pois o total populacional ultrapassa 990 mil habitantes, ambos da região Sudeste. São eles: o Consórcio Público de Gestão de Resíduos Sólidos da Baixada Fluminense no Rio de Janeiro, com população total de 2.905.111 e população média de 484.185 e o Consórcio Consimares de São Paulo, com população total de 989.192 e média de 123.649 habitantes.
} 


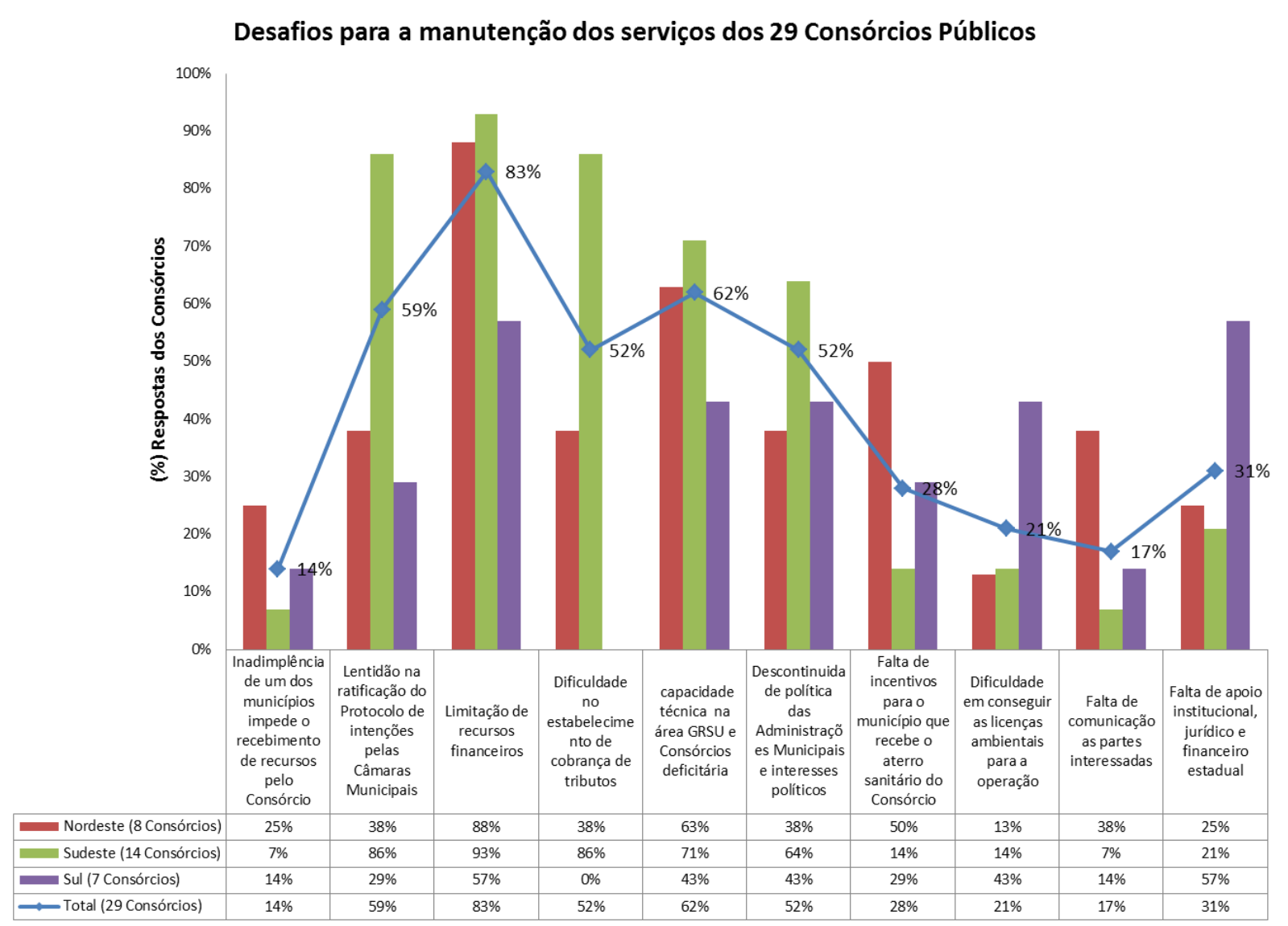

Gráfico 12 - Desafios encontrados pelos Consórcios para a manutenção dos serviços previstos no contrato do Consórcio Público.

Fonte: Elaboração própria, a partir de resultados desta pesquisa.

Para Menezes et al. (2012), o tamanho populacional interfere na capacidade de arrecadação, pois quanto maior for a população, maior é o número de contribuintes e, no caso da provisão de serviços de RSU, o custo per capita de provisão é decrescente em função do tamanho populacional. Neste sentido, o Gráfico 13 mostra o somatório da população total dos municípios consorciados de 27 dos 29 Consórcios, por região, em comparação com a distribuição da média da população de cada Consórcio. Observa-se que a média populacional dos Consórcios é diversificada e que o total populacional também é diferenciado por região.

Nota-se também que não há uma relação direta entre a quantidade de municípios integrantes de um Consórcio e o total populacional do Consórcio. Na região Nordeste, os oito Consórcios possuem entre 3 e 24 municípios e o total populacional dos Consórcios varia de 150 mil a 690 mil habitantes. No Sul, os Consórcios possuem poucos municípios entre 2 e 10 mil habitantes e o total populacional dos Consórcios não ultrapassa 220 mil habitantes. $\mathrm{Na}$ 
região Sudeste, a quantidade de municípios situa-se entre 6 a 28 e o total populacional varia de 40 mil a 2 milhões de habitantes.

$\mathrm{Na}$ região Sudeste, por exemplo, há Consórcios com poucos municípios, como o Consimares em São Paulo com oito municípios, mas com média populacional de 120 mil habitantes, e ao mesmo tempo Consórcios com muitos municípios, como o Consul no Espírito Santo com 28 municípios e média populacional de 17 mil habitantes.

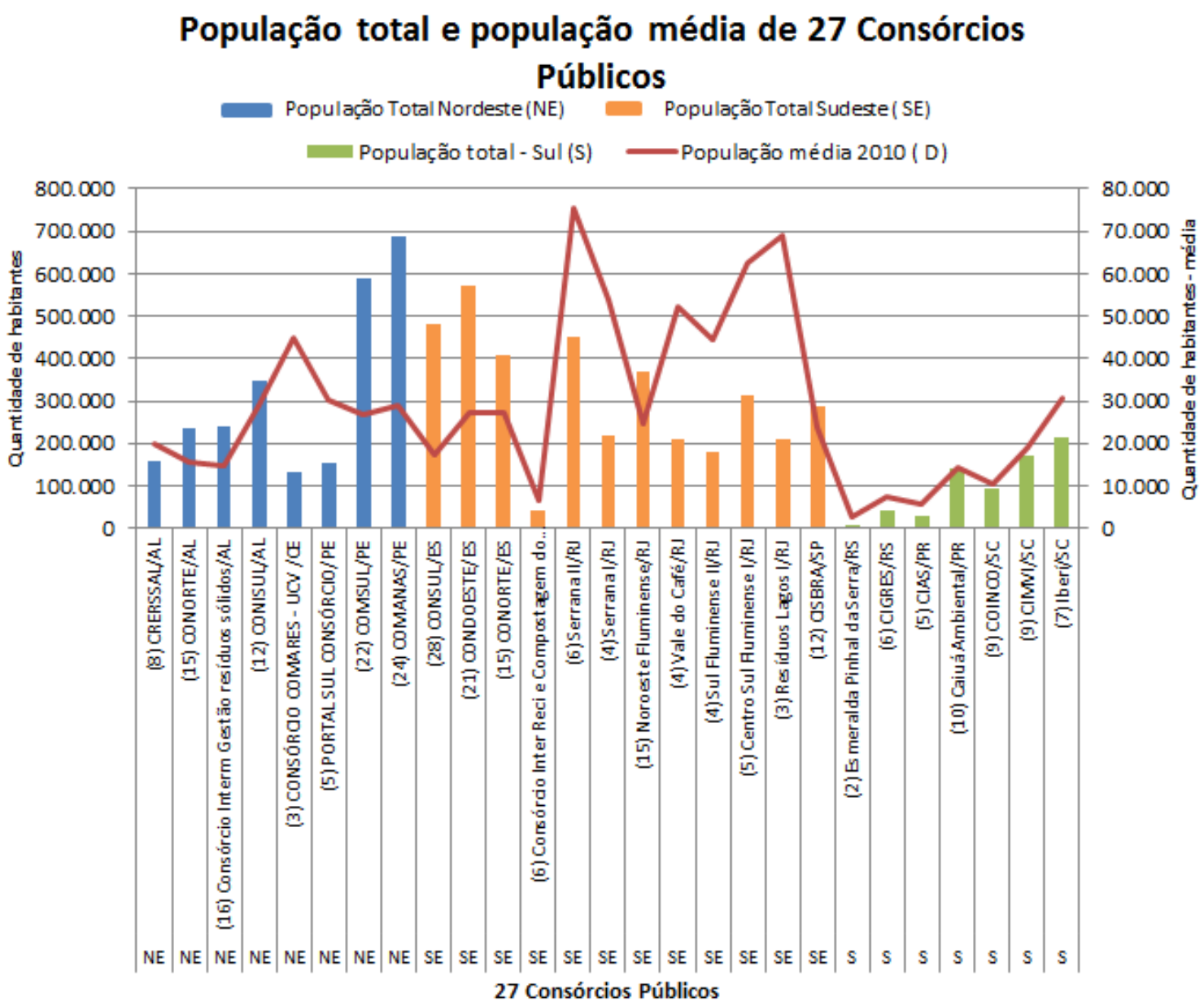

Gráfico 13 - Distribuição da população total e média dos 27 Consórcios Públicos.

Fonte: Elaboração própria, a partir de IBGE, Censo Demográfico 2010 e resultados desta Pesquisa.

Tomando apenas o fator populacional, o Consórcio dos municípios da Mata Norte e Agreste Setentrional de Pernambuco - Comanas teria maior capacidade de arrecadação. No entanto, a quantidade populacional do Consórcio não é o único fator a influenciar a capacidade arrecadatória.

Adicionalmente, o nível de renda municipal influencia sua capacidade de arrecadação tributária, de cobrança de tributo e, como resultado, de realização de investimentos (MENEZES et al., 2012). Para tanto, ao analisarmos o PIB per capita médio dos 29 
Consórcios pesquisados ${ }^{35}$, no Gráfico 14 observa-se um padrão regional dos Consórcios. Os Consórcios da região Nordeste possuem uma variação de PIB per capita médio de R $\$ 4.500$ a $R$ \$ 6.700, os da região Sudeste entre $R$ \$ 10.000 a $R$ \$ 72.000 e os da região Sul entre $R$ \$ 13.000 a $\mathrm{R} \$ 24.900^{36}$. Isso significa que, pela análise comparativa das três regiões do nível renda, os Consórcios da região Nordeste teriam maiores dificuldades de arrecadar recursos por meio de tarifas para a manutenção da prestação dos serviços de RSU.

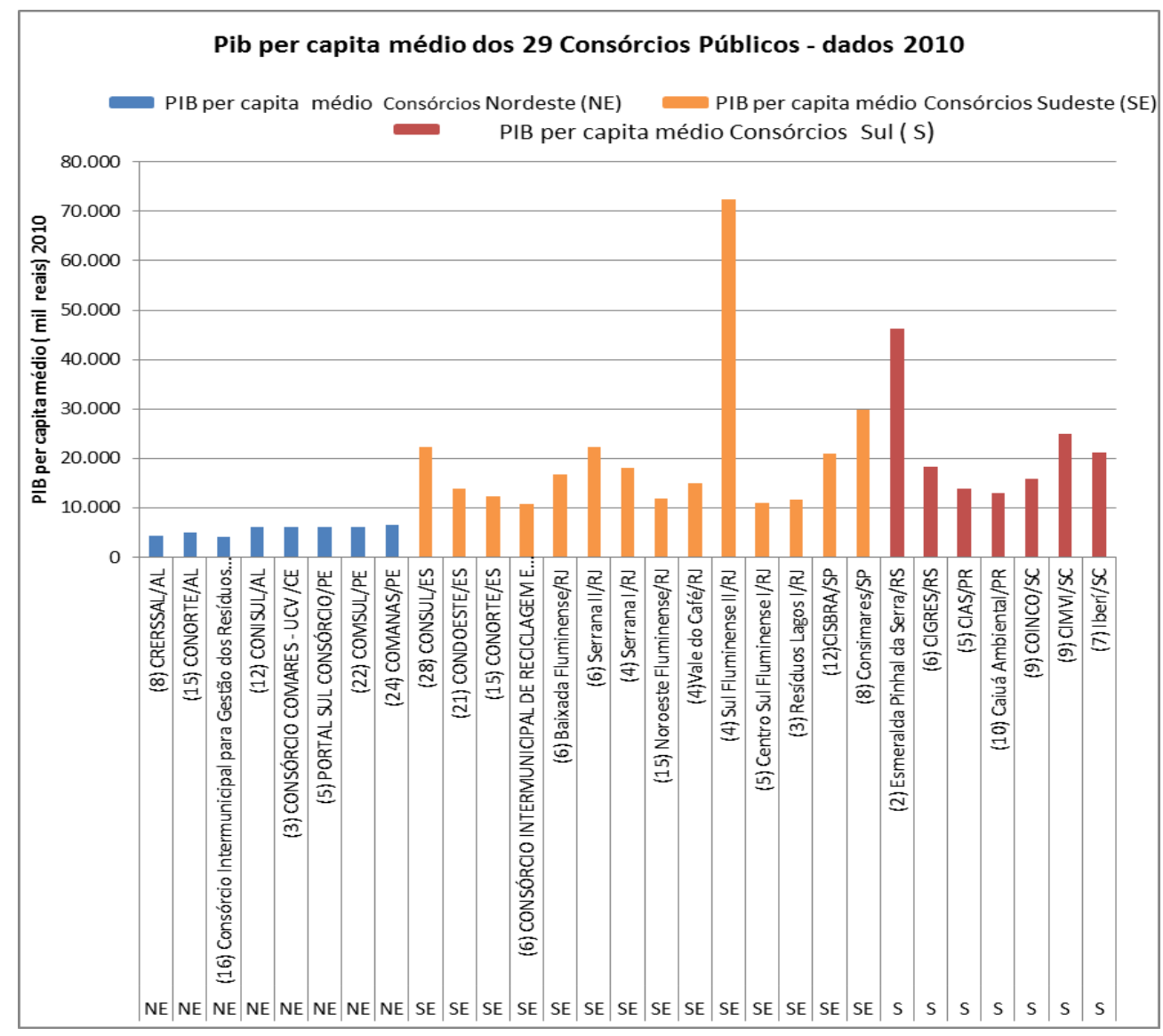

Gráfico 14 - PIB per capita médio dos 29 Consórcios Públicos - dados 2010.

Fonte: Elaboração própria, a partir dos resultados desta pesquisa e IBGE, Censo Demográfico 2010.

O segundo maior desafio apontado pelos Consórcios (Gráfico 12) também se associa à limitação financeira, pois a capacidade técnica deficitária na área de GRSU e Consórcios foram apontados pelos gerentes entrevistados do FNMA e Funasa e pela Auditoria do TCU

\footnotetext{
${ }^{35}$ Os dados do PIB per capita médio dos Consórcios foram calculados a partir dos valores do PIB a preços correntes 2010 e população de 2010 municipal (IBGE, 2010). Disponível em: http://cidades.ibge.gov.br/xtras/home.php. Acesso 13 jun. 2014 e Tabela com os valores no Apêndice E.

${ }^{36}$ Nota-se que o PIB per capita do Brasil em 2010 era de R\$ 19.285 (IBGE, 2014b). Disponível em: http://brasilemsintese.ibge.gov.br/contas-nacionais/pib-per-capita. Acesso em: 17 nov. 2014.
} 
(2011) como um dos motivos do não cumprimento dos requerimentos exigidos para acesso a recursos dos Fundos e Programas pelos municípios e Consórcios para o manejo de RSU.

Este ponto pode ser relacionado ao Índice de Desenvolvimento Humano Municipal IDHM $^{37}$, no sentido de que a GRSU impacta na saúde da população, sua aplicação e reivindicação são influenciadas pelo nível educacional da população e o nível de renda influencia sua capacidade de investimentos e arrecadação.

O Gráfico 15 apresenta o IDHM médio dos 29 Consórcios analisados, dados de $2010^{38}$, de acordo com a faixa de desenvolvimento humano municipal ilustrado na Figura 1. Os Consórcios da região Nordeste, por exemplo, possuem em sua maioria IDHM baixo, e PIB per capita inferior às outras regiões analisadas. Corroborando com as respostas obtidas de ser a região que apresenta maiores dificuldades em carência de recursos financeiros e capacidade técnica.

Faixas de Desenvolvimento Humano Municipal

$$
0
$$

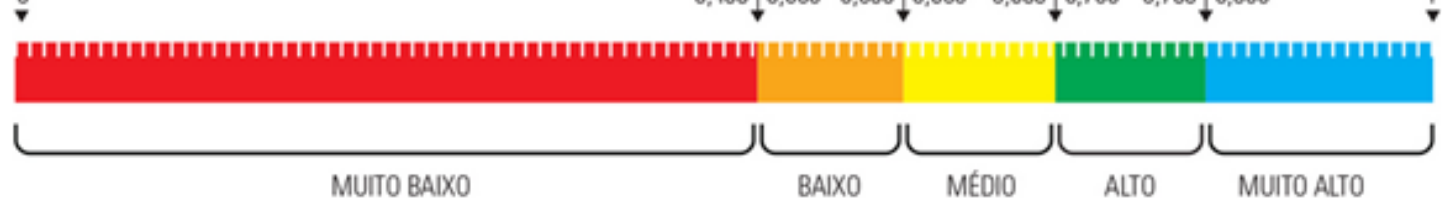

Figura 1 - Faixa de Desenvolvimento Humano Municipal.

Fonte: Atlas Brasil, 2014.

\footnotetext{
${ }^{37}$ O IDHM é composto por três componentes: IDHM Longevidade, IDHM Educação e IDHM Renda. Base de cálculo disponível em: http://www.atlasbrasil.org.br/2013/pt/o_atlas/idhm/

${ }^{38}$ Os dados do IDHM médio 2010 dos Consórcios foram calculados a partir dos valores do IDHM 2010 de cada município (IBGE, 2010), disponível em: http://cidades.ibge.gov.br/xtras/home.php e dados dos 29 Consórcios acessível no Apêndice E.
} 


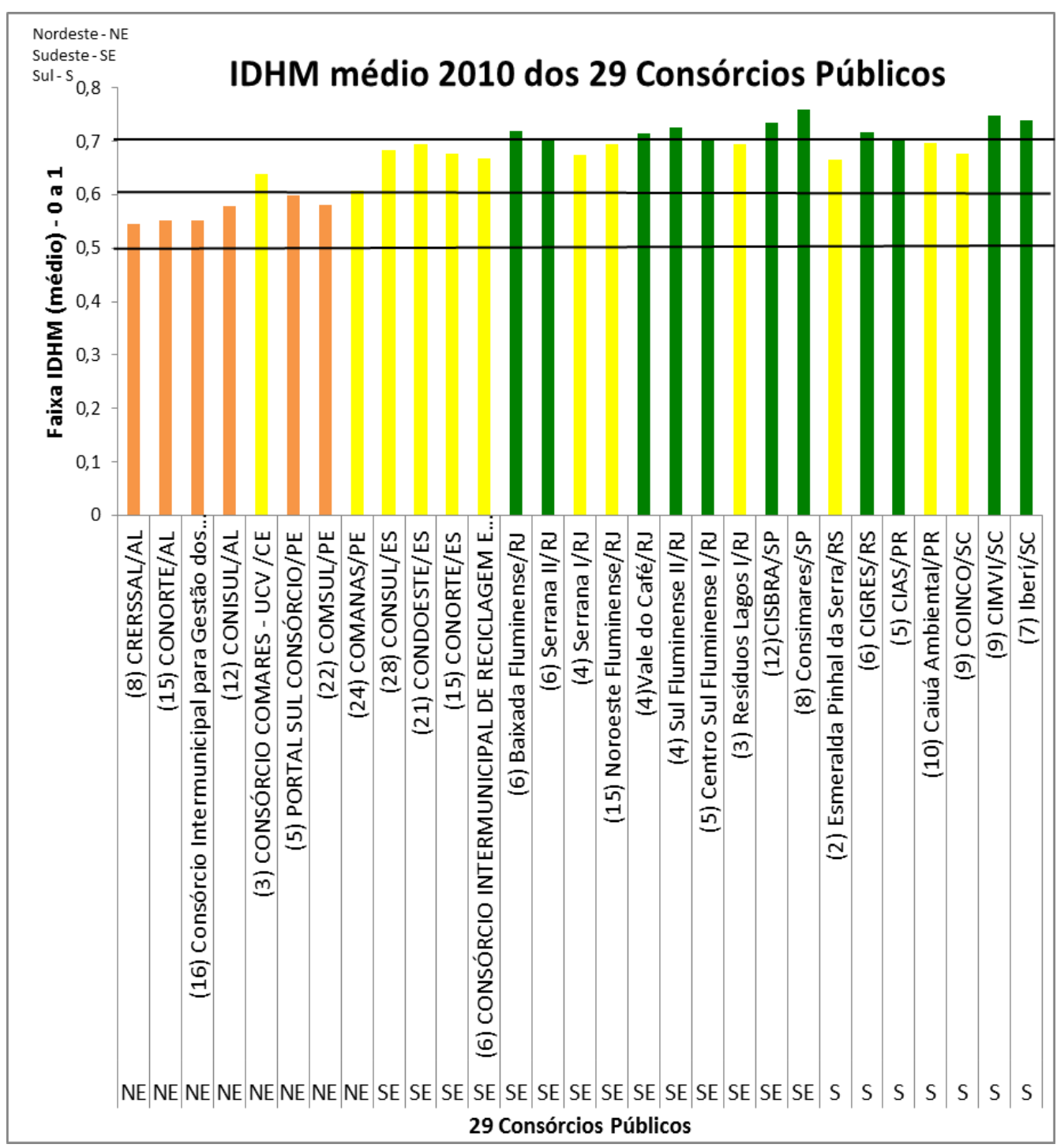

Gráfico 15 - Índice de Desenvolvimento Humano Municipal (IDHM) médio 2010 dos 29 Consórcios Públicos

Fonte: Elaboração própria, a partir de IBGE (Censo 2010) e resultados dessa pesquisa.

A possível inadimplência de um dos entes consorciados impossibilitando o acesso a recursos pelo Consórcio foi apontada nas entrevistas com o FNMA e Funasa como um das justificativas da baixa participação dos Consórcios no acesso aos recursos. No entanto, este desafio foi assinalado como baixo pelos 29 Consórcios. Mais da metade dos Consórcios destacaram questões administrativas e políticas como desafio, como a lentidão na ratificação do Protocolo de Intenções pelas Câmaras Municipais e a descontinuidade política das Administrações Municipais a cada mudança de governo e interesses políticos, reforçando questões analisadas na etapa de primeira fase de formação do Consórcio.

Por outro lado, a falta de comunicação com as partes interessadas: população em geral, comunidades vizinhas ao aterro e catadores de materiais recicláveis, apresentado como uma 
carência na etapa de formação, não é reconhecida como um desafio relevante. A falta de importância dada pelos Consórcios a esta questão corrobora com a baixa execução dos Consórcios das etapas de primeira fase da formação dos Consórcios, inclusive às consultas.

Em relação à construção e operação de aterros, a falta de incentivos para o município que recebe o aterro sanitário do Consórcio e a dificuldade em conseguir as licenças ambientais necessárias para a operação não se mostraram como um desafio expressivo para a manutenção dos serviços, ficando abaixo de $30 \%$. No entanto, dois dos Consórcios ratificaram a lentidão no processo licitatório e atrasos nos projetos executivos como uma dificuldade e justificativa de atraso na operação.

\subsection{Considerações sobre os resultados do estudo de caso com 29 Consórcios Públicos no}

\section{Brasil}

Com base nas análises realizadas no estudo de caso com os 29 Consórcios Públicos é possível fazer algumas considerações sobre como avaliar este instrumento. Os critérios de avaliação - equidade, eficiência, eficácia, incentivo ao esforço máximo, custo administrativo, geração de receita, aceitação política e permanência - podem ser usados no processo de avaliação da implementação de Consórcios como instrumento da PNRS e consequentemente da aplicação de recursos públicos.

Neste sentido, o Quadro 15 apresenta uma proposta do que deve ser considerado em cada critério ao se avaliar a GRSU por Consórcios Públicos, e define os resultados esperados e os principais obstáculos enfrentados para que esses objetivos sejam alcançados, propondo ainda formas de como avaliar se o critério foi alcançado. 
Quadro 15 - Critérios de Avaliação de Políticas Públicas: proposição teórica para Consórcios Públicos para GRSU

\begin{tabular}{|c|c|c|c|}
\hline $\begin{array}{l}\text { Critérios de } \\
\text { Avaliação }\end{array}$ & $\begin{array}{c}\text { Resultados esperados/objetivos dos } \\
\text { Consórcios Públicos para GRSU }\end{array}$ & $\begin{array}{c}\text { Obstáculos enfrentados para alcançar os } \\
\text { objetivos }\end{array}$ & Recomendação de como avaliar o critério \\
\hline Equidade & $\begin{array}{l}\text { Assegurar que a gestão compartilhada dos } \\
\text { serviços prestados pelos Consórcios beneficie } \\
\text { ou compense àqueles que vivem em situação } \\
\text { mais vulnerável, como os que residem } \\
\text { próximos a lixões e aterros, em localidades } \\
\text { pobres ou de risco, que não possuem coleta de } \\
\text { resíduos e convivem com lixo a céu aberto, } \\
\text { suscetíveis a doenças, impacto cênico } \\
\text { negativo e redução do bem-estar. } \\
\text { Garantir que a prestação dos serviços de } \\
\text { resíduos sólidos seja de qualidade semelhante } \\
\text { para todos os municípios integrantes do } \\
\text { Consórcio. } \\
\text { Incluir a população em geral afetada, como a } \\
\text { vizinhança dos lugares de transferência de } \\
\text { resíduos e dos aterros sanitários e os catadores } \\
\text { de materiais recicláveis. }\end{array}$ & $\begin{array}{l}\text { Interesses políticos, desequilíbrio econômico e } \\
\text { institucional dos municípios podem interferir nas } \\
\text { negociações entre os consorciados. } \\
\text { O representante legal do Consórcio é o Chefe do } \\
\text { Poder Executivo; no caso de Consórcios } \\
\text { Intermunicipais, o Prefeito de um dos municípios, o } \\
\text { que pode ocasionar privilégios para os municípios } \\
\text { consorciados de uma mesma base aliada } \\
\text { politicamente e conflitos com os demais. } \\
\text { Dificuldade em definir o local do aterro sanitário, } \\
\text { pois os impactos para o município sede são } \\
\text { maiores. }\end{array}$ & $\begin{array}{l}\text { Averiguar se com a formação do Consórcio, a } \\
\text { prestação de serviço referente aos RSU nos } \\
\text { municípios foi ampliada em localidades pobres ou de } \\
\text { risco e se os impactos para as comunidades vizinhas } \\
\text { das estações de transferência de resíduos e aterros } \\
\text { foram mensurados e compensados. } \\
\text { Avaliar se o ambiente político é favorável à formação } \\
\text { do Consórcio e se os objetivos regionais do Consórcio } \\
\text { irão superar os interesses políticos. } \\
\text { Apurar a realização e avaliação prévia de estudos dos } \\
\text { impactos ambientais, econômicos e sociais da região e } \\
\text { proximidades do município que recebe o aterro } \\
\text { sanitário do Consórcio. Assim como, o Plano Diretor e } \\
\text { as leis de ocupação do uso do solo, documentos de } \\
\text { comprovação da propriedade da terra e as licenças } \\
\text { ambientais para a instalação do aterro sanitário. } \\
\text { Identificar os meios utilizados de escolha e possíveis } \\
\text { incentivos para o município sede e o envolvimento da } \\
\text { população afetada desde as etapas iniciais do } \\
\text { Consórcio. }\end{array}$ \\
\hline Eficiência & $\begin{array}{l}\text { Espera-se a melhoria na prestação dos } \\
\text { serviços, a minimização dos custos e a gestão } \\
\text { compartilhada dos problemas ambientais e } \\
\text { sociais envolvidos. } \\
\text { Comprovar que os custos individuais } \\
\text { municipais com a prestação de serviços de } \\
\text { RSU diminuíram com a integração em um } \\
\text { Consórcio Público. Caso ocorra aumento, } \\
\text { analisar se o mesmo reflete a presença dos } \\
\text { serviços onde antes eles eram inexistentes ou } \\
\text { deficitários. } \\
\text { Verificar se a formação do Consórcio } \\
\text { possibilita a implantação de novas tecnologias } \\
\text { que diminuem os custos e impactos } \\
\text { ambientais. }\end{array}$ & $\begin{array}{l}\text { Os Consórcios são indicados na PNRS e } \\
\text { priorizados no acesso a recursos, justificado na } \\
\text { norma por ganhos de escala, o que levaria à } \\
\text { eficiência - na teoria. Tendo em vista a sua } \\
\text { priorização legal, os Consórcios para GRSU } \\
\text { surgem, a priori, como uma solução second best. } \\
\text { No entanto, a sua aplicação pode ser tão difícil } \\
\text { quanto a solução first best, pelas diferentes } \\
\text { variáveis envolvidas e surgimento de possíveis } \\
\text { novas restrições. Como, por exemplo, a falta de } \\
\text { capacidade técnica, ocasionando a elaboração de } \\
\text { projetos técnicos e estudos ambientais deficientes e } \\
\text { de má qualidade. } \\
\text { A falta do emprego de instrumentos de cobrança } \\
\text { para manutenção dos serviços. }\end{array}$ & $\begin{array}{l}\text { Averiguar a realização das etapas de primeira fase, } \\
\text { que podem indicar que outras características locais e } \\
\text { institucionais determinarão a eficiência ou não dos } \\
\text { Consórcios, como: a localização do aterro sanitário e } \\
\text { distância das estações de transferência de resíduos, a } \\
\text { capacidade de gestão e planejamento do Consórcio, a } \\
\text { capacidade técnica dos gestores e operadores, os } \\
\text { recursos e receitas para a manutenção dos serviços, a } \\
\text { quantidade de resíduos gerados, a implantação de } \\
\text { coleta seletiva e reciclagem, o impacto nas populações } \\
\text { afetadas, a interferência de interesses políticos, entre } \\
\text { outros. } \\
\text { Os Consórcios precisam comprovar meios para a } \\
\text { manutenção dos serviços de RSU, como, a obtenção } \\
\text { de recursos pela aplicação da cobrança pelos serviços. }\end{array}$ \\
\hline
\end{tabular}




\begin{tabular}{|c|c|c|c|}
\hline $\begin{array}{l}\text { Critérios de } \\
\text { Avaliação }\end{array}$ & $\begin{array}{l}\text { Resultados esperados/objetivos dos } \\
\text { Consórcios Públicos para GRSU }\end{array}$ & $\begin{array}{c}\text { Obstáculos enfrentados para alcançar os } \\
\text { objetivos }\end{array}$ & Recomendação de como avaliar o critério \\
\hline Eficácia & $\begin{array}{l}\text { Apurar se os danos ambientais estão } \\
\text { reduzindo diante da aplicação do instrumento, } \\
\text { mensurados pela diminuição de poluição, pela } \\
\text { não geração de resíduos ou pela mudança no } \\
\text { comportamento dos indivíduos e empresas } \\
\text { (UNEP, 2009). Os Consórcios têm o objetivo } \\
\text { de prover um determinado serviço público } \\
\text { específico de interesse coletivo. Nesse sentido, } \\
\text { os Consórcios para GRSU têm o objetivo de: } \\
\text { melhorar a prestação de serviço, reduzir custos } \\
\text { operacionais, minimizar riscos e impactos } \\
\text { ambientais, otimizar o uso de áreas para a } \\
\text { disposição final de RSU, permitir a integração } \\
\text { em regiões de interesse comum, como Bacias } \\
\text { Hidrográficas ou em espaços regionais e } \\
\text { territórios. }\end{array}$ & $\begin{array}{l}\text { A complexidade e o rigor da legislação para } \\
\text { implementação e operação do Consórcio como, por } \\
\text { exemplo, a ratificação do Protocolo de Intenções } \\
\text { nas respectivas Câmaras Municipais, pode acarretar } \\
\text { dificuldades e lentidão ao processo. } \\
\text { A carência municipal de capacidade e formação } \\
\text { técnica e gerencial dos gestores e operadores na } \\
\text { área de Consórcios e no setor de RSU impacta no } \\
\text { planejamento e na gestão de todo o processo. } \\
\text { O critério de proximidade dos municípios a se } \\
\text { consorciarem não é suficiente para sua formação. } \\
\text { Um estudo técnico regional pode mostrar que as } \\
\text { rodovias não são capazes de comportar o tráfego } \\
\text { dos caminhões e de que investimentos adicionais } \\
\text { serão necessários. } \\
\text { Ausência de comprovação de estudos prévios de } \\
\text { viabilidade técnica e econômica do Consórcio e dos } \\
\text { instrumentos de monitoramento e avaliação. }\end{array}$ & $\begin{array}{l}\text { Identificar se há presença de quadro técnico capaz de } \\
\text { planejar e fazer a gestão da logística de transporte dos } \\
\text { resíduos, de equipamentos, se há conhecimento da } \\
\text { legislação Federal, Estadual e Municipal para solicitar } \\
\text { e cumprir as licenças ambientais e elaborar pedidos de } \\
\text { recursos. } \\
\text { Verificar se houve envolvimento da população e das } \\
\text { partes afetadas nas fases iniciais de planejamento e em } \\
\text { todo o processo, pois elas podem trazer informações } \\
\text { da realidade local, problemas e necessidades que } \\
\text { impactam e influenciam na eficácia do Consórcio. } \\
\text { Conferir se antigos lixões foram encerrados e suas } \\
\text { áreas recuperadas, e se não houve surgimento de } \\
\text { novos lixões nos municípios dos Consórcios. } \\
\text { Avaliar se os serviços de coleta, transporte, tratamento } \\
\text { e disposição final estão melhores e mais presentes e } \\
\text { se os danos ao meio ambiente e à saúde pública estão } \\
\text { sendo reduzidos nos municípios onde há Consórcios } \\
\text { de RSU. }\end{array}$ \\
\hline $\begin{array}{l}\text { Incentivo ao } \\
\text { esforço } \\
\text { máximo ou } \\
\text { motivação }\end{array}$ & $\begin{array}{l}\text { Comprovar que a junção dos municípios para } \\
\text { a GRSU permite a aplicação de soluções } \\
\text { inovadoras que reduzem os danos ambientais } \\
\text { e os custos econômicos. }\end{array}$ & $\begin{array}{l}\text { Os municípios possuem incentivos de priorização } \\
\text { no acesso a recursos se forem partes integrantes de } \\
\text { Consórcios Públicos e a PNRS determina como } \\
\text { instrumento a cooperação e o aprimoramento de } \\
\text { tecnologias limpas para minimizar os impactos } \\
\text { ambientais. No entanto, não são claros quais } \\
\text { incentivos os Consórcios teriam ao aplicarem ou } \\
\text { buscarem formas e soluções inovadoras. }\end{array}$ & $\begin{array}{l}\text { Conferir se há incentivos para que os Consórcios } \\
\text { busquem um comportamento inovador para a gestão e } \\
\text { o gerenciamento dos RSU. }\end{array}$ \\
\hline
\end{tabular}




\begin{tabular}{|c|c|c|c|}
\hline $\begin{array}{l}\text { Critérios de } \\
\text { Avaliação }\end{array}$ & $\begin{array}{c}\text { Resultados esperados/objetivos dos } \\
\text { Consórcios Públicos para GRSU }\end{array}$ & $\begin{array}{c}\text { Obstáculos enfrentados para alcançar os } \\
\text { objetivos }\end{array}$ & Recomendação de como avaliar o critério \\
\hline $\begin{array}{l}\text { Custo } \\
\text { administrativo }\end{array}$ & $\begin{array}{l}\text { Um dos objetivos da junção dos municípios } \\
\text { por meio dos Consórcios é a redução dos } \\
\text { investimentos e dos custos envolvidos para a } \\
\text { GRSU e da cooperação dos recursos físicos e } \\
\text { técnicos. Por exemplo, espera-se que o } \\
\text { compartilhamento de um aterro sanitário, } \\
\text { pelos municípios represente redução dos } \\
\text { custos operacionais para os consorciados. } \\
\text { Os Consórcios precisam de um planejamento } \\
\text { inicial que garanta o financiamento dos } \\
\text { recursos necessários. Mesmo as previsões de } \\
\text { instrumentos econômicos que forneçam } \\
\text { fundos por meio de tributos precisarão de um } \\
\text { financiamento inicial para estabelecer o } \\
\text { Consórcio. } \\
\text { É necessário comprovar a origem das receitas } \\
\text { para cobrir os custos da prestação dos serviços } \\
\text { de RSU pelos Consórcios, seja por } \\
\text { arrecadação, diretamente dos orçamentos } \\
\text { municipais ou subsidiada. }\end{array}$ & $\begin{array}{l}\text { A priorização no acesso a recursos pode auxiliar o } \\
\text { financiamento inicial, mas não sustentará as } \\
\text { atividades em longo prazo. } \\
\text { A disposição final dos RSU em um aterro sanitário } \\
\text { em um dos municípios do Consórcio é apenas um } \\
\text { fator que pode trazer redução dos custos } \\
\text { operacionais, uma vez que aterros menores } \\
\text { possuem custos de operação mais elevados que } \\
\text { aterros de médio e grande porte. No entanto, há } \\
\text { uma lacuna no planejamento dos custos com } \\
\text { pessoal técnico, coleta, transporte, equipamentos, } \\
\text { condicionantes de licenças ambientais e recursos } \\
\text { para manutenção do aterro e da prestação dos } \\
\text { serviços em geral. } \\
\text { A falta de capacidade técnica para GRSU. } \\
\text { A ausência de orçamento específico municipal para } \\
\text { o setor de RSU e a dificuldade de criação, } \\
\text { implantação e cobrança pelos serviços é um } \\
\text { problema municipal e que recai para os Consórcios. } \\
\text { A não cobrança pelos serviços faz com que a } \\
\text { população não tenha incentivo para reduzir a } \\
\text { geração de resíduos, o que leva à demanda de } \\
\text { maiores e novas infraestruturas. }\end{array}$ & $\begin{array}{l}\text { Verificar se as responsabilidades das Prefeituras e do } \\
\text { Consórcio estão bem definidas e se a forma de } \\
\text { execução pelo próprio Consórcio ou por meio de } \\
\text { Concessão ou Parceria Público Privada (PPP) foi } \\
\text { avaliada, pois cada uma terá uma dinâmica diferente } \\
\text { de custos. } \\
\text { Averiguar se houve a inclusão no planejamento dos } \\
\text { custos do Consórcio de programas de comunicação e } \\
\text { Educação A que envolvam as partes interessadas e a } \\
\text { população, para que os envolvidos compreendam a } \\
\text { importância dos serviços e a necessidade de } \\
\text { pagamento de tributos. } \\
\text { Comprovar se existe recursos e receitas para a } \\
\text { manutenção e auto- sustentação dos serviços prestados } \\
\text { pelo Consórcio, pois uma das características dos } \\
\text { serviços de resíduos sólidos é a necessidade de } \\
\text { investimentos e manutenção contínua e ininterrupta. }\end{array}$ \\
\hline
\end{tabular}




\begin{tabular}{|c|c|c|c|}
\hline $\begin{array}{l}\text { Critérios de } \\
\text { Avaliação }\end{array}$ & $\begin{array}{c}\text { Resultados esperados/objetivos dos } \\
\text { Consórcios Públicos para GRSU }\end{array}$ & $\begin{array}{c}\text { Obstáculos enfrentados para alcançar os } \\
\text { objetivos }\end{array}$ & Recomendação de como avaliar o critério \\
\hline $\begin{array}{c}\text { Aceitação } \\
\text { Política }\end{array}$ & $\begin{array}{l}\text { A aceitação política dos Consórcios passa } \\
\text { pelos próprios prefeitos e partidos políticos } \\
\text { dos municípios que pretendem realizar uma } \\
\text { gestão compartilhada para prestação dos } \\
\text { serviços de RSU. E em seguida, é avaliada } \\
\text { pelos Órgãos Municipais responsáveis pela } \\
\text { limpeza urbana, empresas do setor, pela } \\
\text { população beneficiada pelas soluções e } \\
\text { afetada pelos problemas, como por exemplo, } \\
\text { os catadores de materiais recicláveis, a } \\
\text { vizinhança de estações de transferência de } \\
\text { resíduos e aterros sanitários e a comunidade } \\
\text { em geral municipal que precisa dos serviços. }\end{array}$ & $\begin{array}{l}\text { A gestão dos Consórcios está vinculada aos } \\
\text { Prefeitos dos Municípios, o que pode gerar } \\
\text { conflitos de ideologias partidárias e problemas } \\
\text { quando da mudança de governos após eleições } \\
\text { refletindo na qualidade e continuidade da prestação } \\
\text { dos serviços de RSU pelos Consórcios. } \\
\text { A não aceitação por segmentos sociais, empresas, } \\
\text { comunidades próximas às instalações de } \\
\text { transferência e de aterro compromete a operação e } \\
\text { gera custos adicionais ao Consórcio. }\end{array}$ & $\begin{array}{l}\text { Atestar se existe engajamento dos prefeitos dos } \\
\text { municípios integrantes dos Consórcios e vontade } \\
\text { política. } \\
\text { Conferir se houve envolvimento das partes } \\
\text { interessadas, desde as fases iniciais de estudos de } \\
\text { viabilidade e depois em todo o processo. Consultar as } \\
\text { partes afetadas significa ter informações adicionais da } \\
\text { realidade local e antecipar possíveis problemas. } \\
\text { Confirmar se outros segmentos de cada município } \\
\text { foram envolvidos para garantir a execução dos } \\
\text { Consórcios, como, por exemplo, as Câmaras } \\
\text { Municipais para a ratificação dos Protocolos de } \\
\text { Intenções. }\end{array}$ \\
\hline Permanência & $\begin{array}{l}\text { Capacidade dos Consórcios de oferecer } \\
\text { continuidade dos serviços diante das } \\
\text { exigências impostas pela PNRS e mesmo com } \\
\text { as mudanças de Prefeitos em cada eleição e } \\
\text { auto-sustentação de recursos para manutenção } \\
\text { dos serviços. }\end{array}$ & $\begin{array}{l}\text { Não há mecanismos de prevenção para } \\
\text { inadimplência de consorciados, o que prejudica a } \\
\text { prestação dos serviços e impacta a obtenção de } \\
\text { financiamentos. } \\
\text { Por ser uma forma voluntária de arranjo regional, } \\
\text { os municípios podem entrar ou sair dos Consórcios, } \\
\text { o que impacta na gestão e no seu planejamento. } \\
\text { Municípios pequenos que conseguem recursos para } \\
\text { construção de aterros sanitários muitas vezes não } \\
\text { conseguem mantê-los e a área torna-se um lixão. } \\
\text { Pergunta-se se a junção dos municípios por meio de } \\
\text { Consórcios pode mudar esta realidade? } \\
\text { A junção de municípios significa também a ligação } \\
\text { de partidos políticos, ou seja, de ideias partidárias e } \\
\text { interesses políticos diversos. Tais interesses } \\
\text { políticos e mudança de representantes a cada } \\
\text { eleição comprometem a consolidação e } \\
\text { continuidade institucional do Consórcio. }\end{array}$ & $\begin{array}{l}\text { Averiguar de que forma o estado pode contribuir para } \\
\text { a manutenção dos serviços do Consórcio, como: apoio } \\
\text { institucional, jurídico e financeiro. } \\
\text { Os Consórcios precisam comprovar a geração de } \\
\text { recursos para manter a infraestrutura do Consórcio e a } \\
\text { prestação dos serviços, especialmente se houver } \\
\text { aterros sanitários. } \\
\text { Avaliar se os Consórcios são sustentados apenas } \\
\text { quando a opinião pública está atenta ao problema } \\
\text { devido às exigências impostas pela PNRS ou que } \\
\text { basta a atenção ser desviada para outras questões que } \\
\text { o não cumprimento da PNRS e o comportamento } \\
\text { anterior voltam a ocorrer. }\end{array}$ \\
\hline
\end{tabular}

Fonte: Elaboração própria, a partir de MENDES, 2013; LIPSEY, 2007; UNEP, 2009; PEQUENO, 2013; IPEA, 2012; NASCIMENTO NETO e MOREIRA, 2012. 
Diante da visão proposta no Quadro 15 e com base na análise dos resultados obtidos das respostas dos 29 Consórcios Públicos, as análises a seguir apresentam uma síntese das lições aprendidas do estudo de caso com base nos critérios de avaliação apresentados.

\section{Equidade}

A disposição final dos RSU é o principal objetivo e, consequentemente, a construção de aterros sanitários. No entanto, com as respostas obtidas não foi possível avaliar a diferença da prestação dos serviços entre os municípios que recebem o aterro e os outros consorciados. Além disso, constatou-se baixa proporção de estudos territoriais, de ocupação do uso do solo e distância entre os municípios nas respostas dos 29 Consórcios. Tal fato pode impossibilitar o planejamento da construção de aterros sanitários regionais e compartilhados.

A ausência de Planos dificulta a existência de parâmetros para averiguar se a prestação dos serviços de RSU foi ampliada em localidades pobres ou de risco e se os impactos foram mensurados nos municípios com Consórcios, pois é necessário avaliar os dados de prestação com o Consórcio e sem o Consórcio.

A inclusão das partes afetadas foi considerada baixa ao se constatar que, nas etapas de formação, a consulta às partes afetadas ficou abaixo de $30 \%$. De acordo com as perguntas realizadas, não foi possível avaliar a relação e inclusão dos catadores de materiais recicláveis nos Consórcios.

\section{Eficiência}

A carência de recursos financeiros municipais individuais foi apontada como um dos incentivos predominantes para a criação dos Consórcios. Essa falta de recursos apoia a hipótese de que a priorização no acesso a recursos da União ou incentivos instituídos pelo Governo Federal garantidos pela PNRS é um incentivo para a formação dos Consórcios ao se constatar que dos 8 Consórcios que responderam que a priorização no acesso a recursos é um incentivo, 6 foram criados após a PNRS.

No entanto, a maioria dos Consórcios pesquisados não possui PIGRS ou os municípios o PMGIRS. Com isso, não podem ter acesso a recursos da União, pois ter um dos Planos é uma obrigatoriedade da Lei (BRASIL, Art. 18, 2010a). 


\section{Eficácia}

Pouco mais da metade dos 29 Consórcios efetuaram um diagnóstico da geração de RSU de cada município consorciado. Doze Consórcios informaram não possuir nenhum dos Planos, apenas sete assinalaram possuir o PMGIRS e quatro o PIGRS. Os demais não responderam. A falta dos Planos interfere no planejamento do Consórcio para a GRSU, podendo demandar mais esforços e recursos nas etapas de formação, pois várias etapas iniciais da formação dos Consórcios fazem parte do PGIRS, como: realização de estudos de viabilidade econômico-financeiro, ambientais e sociais, territoriais e diagnósticos sobre a geração de resíduos.

Os 29 Consórcios apresentaram uma elevada porcentagem de realização das etapas de ratificação e aprovação do Estatuto. A elaboração do Protocolo de Intenções dos 29 Consórcios foi realizada entre os anos de 1998 a 2013 e a maioria dos Consórcios a concluiu. Entre a elaboração do Protocolo e a ratificação, os Consórcios assinalaram sua realização ambos no mesmo ano ou em até 2 anos da data da elaboração. No entanto, dos 29 Consórcios, 93\% assinalaram que possuem o Protocolo de Intenções contra apenas $31 \%$ que estão em operação. Caso o restante entre em operação em 2014, os Consórcios demorariam em média 4 a 5 anos entre a elaboração do Protocolo e a operação, etapas determinadas na LCP.

\section{Incentivo ao esforço máximo ou motivação}

Não houve perguntas direcionadas ao tema. Com isso, as respostas dos 29 Consórcios não possibilitaram identificar a aplicação de soluções inovadoras que reduzem danos ambientais e custos econômicos ou meios que as incentivam. Apenas o Consórcio Intermunicipal Esmeralda/Pinhal da Serra do Rio Grande do Sul indicou que obtém recursos advindos da venda com o material reciclado recolhido, demostrando o aproveitamento de oportunidades de mercado.

\section{Custo administrativo}

A prefeitura é a maior fonte de recursos dos processos de varrição e limpeza, coleta regular, coleta seletiva, transporte e construção de galpão para triagem para recuperação de materiais recicláveis ou pátio de compostagem. Os contratos do Consórcio aparecem com maior fonte de recursos para a construção, operação e manutenção dos aterros sanitários. Além disso, apenas um Consórcio assinalou a cobrança pela prestação de serviço e outro a utilização de ICMS Ecológico. 
Embora a cobrança pelos serviços prestados em RSU seja garantida por Lei, sua prática é insuficiente. A tendência é que os Fundos exijam comprovação dos municípios e Consórcios para continuidade das atividades. Todavia, apenas metade dos 29 Consórcios assinalou a cobrança de tributos como um desafio para cobrir os gastos com a manutenção dos serviços.

A falta do emprego de instrumentos de cobrança para manutenção dos serviços causa o mesmo problema já enfrentado pelo município antes do Consórcio - falta de recursos, o que pode ocasionar os problemas apurados pela Auditoria do TCU (2011) na avaliação dos recursos aplicados pela Funasa para o manejo de RSU, com aterros que retornaram à condição de lixões. Os PGIRS devem prever instrumentos de cobrança pelos serviços, assim como os Protocolos de Intenções dos Consórcios.

O déficit de capacidade técnica municipal e consequentemente dos Consórcios ficou evidente ao longo das pesquisas com os Fundos e confirmado com as repostas dos Consórcios, e que representa um custo adicional que os Consórcios terão, ou em capacitar gestores dos municípios ou com novas contratações. Além de impactar no acesso a recursos, no planejamento e execução das atividades. Adicionalmente, a ausência de PGIRS demandará mais esforços e recursos nas etapas de formação dos Consórcios.

Nos 29 Consórcios estudados, não houve perguntas diretas sobre a construção ou operação de aterros; no entanto, como o objetivo majoritário dos consórcios é a disposição dos resíduos, conclui-se que a avaliação da localização do aterro é fundamental por seu impacto nos custos.

\section{Aceitação Política}

Dos 29 Consórcios, apenas 30\% realizaram consultas e envolveram as partes interessadas no processo de formação do Consórcio e metade consultaram as Secretarias, que de alguma forma possuem atividades relacionadas à GRSU. Metade dos 29 Consórcios destacaram questões administrativas e políticas como desafio, como a lentidão na ratificação do Protocolo de Intenções pelas Câmaras Municipais. Além disso, questiona-se o engajamento dos Prefeitos na constatação da falta de informação das Prefeituras consorciadas na etapa de levantamento dos Consórcios do presente estudo. 


\section{Permanência}

A descontinuidade política das Administrações Municipais a cada mudança de governo e interesses políticos foram apontados como um dos desafios por metade dos 29 Consórcios.

O papel dos governos federais e estaduais e das consequências para a permanência e eficiência da PNRS caso os municípios não tenham o apoio das outras esferas governamentais pode ser questionado. Os dados dos 29 Consórcios, 19 Intermunicipais e 10 entre estado e municípios, não podem afirmar que o último tem maiores chances de permanência. No entanto, os dados constatam que estes se beneficiam com apoio estadual técnico, financeiro, institucional e de regulação. Sendo estes fatores apontados pelos Consórcios como um ponto adicional de estímulo para a formação desse tipo de Consórcio. Diante da ausência de capacidade técnica verificada, os Consórcios entre estados e municípios merecem maiores estudos. 


\section{CONSIDERAÇÕES FINAIS}

A Política Nacional de Resíduos Sólidos - PNRS é considerada um importante marco na normatização do setor de resíduos sólidos. No entanto, a exigência do cumprimento da Lei sem a análise da capacidade dos munícipios em cumpri-la pode levar a sua ineficácia e à ineficiência no uso de recursos. A motivação desta dissertação foi avaliar as consequências da priorização e do incentivo ao acesso a recursos governamentais oferecidos pela PNRS aos municípios para formação de Consórcios Públicos para a gestão regionalizada da prestação de serviços de RSU. Para tanto, a dissertação levantou e avaliou as fontes de recursos governamentais que possuem linhas de financiamento para o setor de RSU - FNMA, FNDCT, FNMC e Programa de Manejo de Resíduos Sólidos da FUNASA - e identificou as características dos Consórcios Públicos para GRSU no Brasil por meio de um estudo de caso com 29 Consórcios Públicos das regiões Nordeste, Sudeste e Sul.

Ao longo do trabalho, portanto, a falta de dados e de informações acerca do tema “Consórcios públicos na gestão de RSU” levou à ampliação de nossa motivação, com fins de se aprofundar e se ampliar o conhecimento sobre a questão.

A ausência de uma base de dados nacionais dos Consórcios Públicos adicionou a necessidade de levantamento dos Consórcios Públicos para GRSU existentes no Brasil, pois não há nenhum Órgão Federal ou/e Estadual que concentre as informações dos Consórcios Públicos constituídos para GRSU.

Além disso, houve a necessidade de entrevistas, aplicação de questionários e contatos telefônicos. Os dados coletados foram organizados e resumidos com o objetivo de facilitar as análises e as interpretações foram agrupadas em tabelas e gráficos. A falta de informação constatada é um sinalizador da ausência de avaliação do processo como um todo e da relevância dessa dissertação.

Os resultados das entrevistas realizadas com os gerentes dos Fundos e a análise dos financiamentos governamentais disponibilizados mostraram que ainda não se identifica uma estrutura definida de fontes de financiamento para o setor de resíduos sólidos. Além disso, observou-se pouca expressividade no repasse de recursos públicos das diferentes esferas aos Consórcios Públicos. A PNRS não define a criação de um Fundo próprio ao setor de resíduos sólidos; os dois Fundos estipulados pela Lei como instrumentos e analisados neste estudo FNMA e FNDCT, não têm como foco primordial o setor de resíduos sólidos. O FNMC e o Programa da Funasa não são instrumentos da PNRS, mas possuem linhas de financiamento para a GRSU. 
A diversidade dos setores desses Fundos (meio ambiente, ciência, tecnologia e inovação, mudanças climáticas e saúde) demonstra que a questão da GRSU não está presente apenas nas agendas de políticas públicas de resíduos sólidos e saneamento. No entanto, a não construção de políticas de forma transversal entre os Ministérios e as Agências leva ao conflito de ações e à ineficiência na aplicação dos recursos públicos.

Compreender a dinâmica das fontes de financiamentos por meio de pesquisa, entrevistas e análise dos dados dos Fundos e Programas foi determinante para a construção do estudo de caso com os Consórcios Públicos para a GRSU, pois foi possível identificar as limitações existentes, tais como: a carência técnica de ambos os lados, do governo federal que disponibiliza os recursos e do governo municipal que almeja o recebimento; as consequências da falta de PGIRS, que leva os municípios a não conseguir cumprir as exigências dos Editais; a falha no planejamento do governo federal, na falta de monitoramento durante e após o repasse dos recursos, na falta de definição de parâmetros para decidir quais propostas devem ser aceitas, no quadro de servidores reduzidos e na falta de capacidade técnica no setor de resíduos sólidos.

O estudo de caso com os 29 Consórcios Públicos possibilitou uma visão empírica do cenário atual dos Consórcios Públicos para a GRSU no Brasil. Os resultados evidenciaram que os pequenos municípios têm buscado a gestão compartilhada de RSU por meio da formação de Consórcios Públicos. Constatou-se que, na amostra dos 29 Consórcios Públicos, totalizando 285 municípios, a formação de consórcios tende a se concentrar nos municípios com até 50.000 habitantes, sendo a maior parte situada nas faixas entre 10.001 a 50.000 habitantes.

As respostas dos 29 Consórcios mostram uma tendência à formação de Consórcios tendo como principal objetivo o processo de disposição final como um todo, como a operação e construção de aterros regionais, o fechamento de lixões e recuperação de áreas degradadas, ou seja, concentra-se na fase final do processo de gestão e gerenciamento de resíduos previstos na PNRS (BRASIL, Art. 9, 2010a).

O estudo de caso com os 29 Consórcios Públicos destacou que, dependendo de interesses e necessidades comuns dos municípios, os Consórcios podem atender diferentes objetivos ou setores em um mesmo contrato; são os chamados Consórcios multifinalitários, o que pode diminuir custos administrativos e aumentar a cooperação regional. O Consórcio pode ser o próprio prestador de serviços da gestão de resíduos sólidos ou delegar os serviços, por meio da terceirização ou por meio de Concessão ou Parceria Público-Privada (PPP); o 
contrato de programa é o mais presente, seguido pela concessão e, por último, pelas parcerias público-privadas (PPP).

A necessidade de cumprimento da PNRS e a carência de recursos financeiros municipais são estímulos dominantes à formação de Consórcios para GRSU. Além disso, atestou-se que a priorização no acesso a recursos da União ou incentivos instituídos pelo Governo Federal garantidos pela PNRS foi um incentivo relevante para os Consórcios criados após a PNRS. No entanto, tal incentivo não assegura a eficiência dos Consórcios, pois outras variáveis estão envolvidas e há possibilidade de novas restrições no acesso a recursos financeiros.

A ausência de PMGIRS e PIGRS é uma dessas restrições e foi informada ao longo de toda a pesquisa, confirmando dados do IBGE (2014) que mostram que 66,5\% dos municípios não possuem um PGIRS de acordo com os termos da Lei.

Esse fato mostra a falta de planejamento na formação de Consórcios, impedindo-os de ter acesso a recursos governamentais e de obter informações da realidade do setor, de suas características e da real demanda por esse tipo de serviço.

Reconhece-se, com isso, que a elaboração de PGIRS deve ser prioridade para municípios e que deveria ocorrer antecedentemente à criação de Consórcios. Ressalta-se, ainda, que mais relevante do que possuir um Plano e exigir a sua elaboração é garantir que ele reflita a realidade e necessidades locais.

Com isso, recomenda-se que estudos e avaliações sejam realizados para averiguar se e como esses Planos têm sido elaborados, a qualificação de seus elaboradores, a representação da realidade local e se potencialmente podem gerar eficácia, eficiência e equidade.

O estudo com os Consórcios que responderam ao nosso questionário demostram que a formação dos Consórcios concentra-se nas fases finais determinadas pela Lei de Consórcios Públicos - LCP e que as etapas de primeira fase que permitem reconhecer o problema e traçar soluções são negligenciadas. A ausência das etapas iniciais para a formação do Consórcio interfere no seu funcionamento e coloca em risco a sua permanência. Etapas relevantes para a seleção de escolhas potencialmente eficientes e eficazes não estão sendo realizadas, a exemplo da seleção do local onde o aterro é localizado, que não é precedida de estudos territoriais, de avaliação de distâncias entre os municípios e de avaliações de questões geográficas, ambientais e econômicas. 
Foram constatados diversos outros problemas, como a ausência de planejamento adequado - inclusive de estimativa de recursos para a manutenção dos serviços e de avaliação de formas e de valores de cobrança e de monitoramento.

Portanto, a priorização aos recursos públicos pela formação de consórcios assegurada na PNRS não está necessariamente associada a uma gestão eficiente, podendo potencialmente induzir ineficácia e ineficiência da política de gestão de resíduos sólidos, entre outros problemas relevantes. Identifica-se aí uma falha de política ao não se levar em consideração que, se há falta de Planos e de capacidade técnica, os objetivos da Lei ao prever esta priorização no acesso aos recursos não são alcançados.

Colocar um Consórcio em funcionamento exige planejamento, pois os custos administrativos são altos. Iniciar suas atividades sem se assegurar que haverá recursos para a manutenção e mecanismos de cobrança pela prestação dos serviços induz também a soluções longe da eficiência, como o retorno de aterros à condição de lixões quando da ausência de recursos para sua manutenção. Reconhece-se, pelos resultados obtidos pela Auditoria do TCU (2011) ao Programa da Funasa e pelas respostas da amostra dos 29 Consórcios ao longo da pesquisa, que a falta de recursos para a manutenção dos serviços de RSU é um fator limitante para a permanência da prestação dos serviços. Esses recursos necessitam ser assegurados, por meio de estudos de viabilidade técnica de valores e tipos de cobrança adequados. Nesse sentido, as análises dos Fundos e Programas demostraram que existe uma lacuna de planejamento sobre onde e como os recursos devem ser aplicados e também não se assevera a capacidade dos Consórcios e municípios na utilização dos recursos públicos e em se assegurar a continuidade dos serviços.

Pelo exposto, reduzir o problema à falta de recursos seria simplificar a situação, já que há falta de planejamento, capacidade técnica e monitoramento. Nesse sentido, a UNEP (2009) adverte que os processos de avaliação de políticas precisam ser implementados desde o início da concepção de políticas, programas e projetos, para que, dessa forma, seja possível avaliar o progresso e efetuar modificações quando necessário for. Na dissertação, os critérios de avaliação - equidade, eficiência, eficácia, incentivo ao esforço máximo, custo administrativo e geração de receita, aceitação política e permanência - foram utilizados para avaliar os resultados do estudo de caso com os 29 Consórcios e uma proposição teórica de como avaliar cada um desses critérios foi sugerida.

Os resultados apontam que os itens de 1 a 7, a seguir, necessitam ser implementados em gestão de RS por meio de Consórcios Públicos. 
1. Incentivo à transversalidade setorial para GRSU;

2. Maior envolvimento federal ou/e estadual na formação dos Consórcios para GRSU;

3. Fortalecimento da capacidade técnica e institucional nas três esferas governamentais, principalmente a municipal, na área de resíduos sólidos urbanos, com destinação de recursos e programas para este fim;

4. Implementação de instrumentos de cobrança pelos serviços prestados de RS;

5. Direcionamento de recursos para a elaboração de PGIRS;

6. Estímulo à realização das etapas de primeira fase - diagnósticos; estudos de viabilidade econômico-financeira, ambientais, sociais, territoriais e distância entre os municípios para a seleção do sítio do aterro; planejamento; e consultas às partes interessadas;

7. Inclusão de mecanismos de monitoramento e avaliação.

Conclui-se, então, que propostas para a gestão de RSU devem assegurar soluções eficientes, eficazes e que apresentem equidade. No entanto, quando se priorizam recursos públicos para a formação de Consórcios com esse fim não necessariamente se alcançam esses objetivos, uma vez que existem desafios que não estão sendo avaliados, como os listados neste capítulo, e que impactam negativamente tanto a formação dos Consórcios quanto a GRSU no país. 


\section{REFERÊNCIAS BIBLIOGRÁFICAS}

ABRELPE (Associação Brasileira de Empresas de Limpeza Pública e Resíduos Especiais). Panorama dos resíduos sólidos no Brasil 2012. Edição Especial de 10 anos.

AMARAL, João Renato. Superintendente do NISB/COMSUL (Consórcio Público dos Municípios da Mata Sul Pernambucana). Informação verbal. Contato por $e$-mail em 27 mai.14.

ANDRADE, Eduardo C. Externalidades. In: BIDERMAN, C.; ARVATE, P. (Org.). Economia do Setor Público no Brasil. Elsevier, 2005. Cap 2, p. 16- 33.

ATLAS BRASIL. Atlas do Desenvolvimento Humano no Brasil. Índice de Desenvolvimento Humano Municipal (IDHM). Faixa de Desenvolvimento Humano Municipal. Disponível em: <http://www.atlasbrasil.org.br/2013/pt/o_atlas/idhm/>. Acesso em: 27 jun. 2014.

BARRETO, Rodrigo. Coordenação de Saneamento em Saúde, FUNASA. Comunicação Pessoal. Entrevistas concedidas em 03 e 11 abr. de 2014.

BAUMOL. William J.; OATES, Wallace E. Direct Controls Versus the Pricing System. In:__ Economics, Environmental Policy, and the Quality of Life. Prentice-Hall, 1979, cap. 16, p. 232-245.

BITHAS, Kostas. Sustainability and externalities: Is the internalization of externalities a sufficient condition for sustainability? Ecological Economics, v. 70, p. 1703 - 1706, 2011.

BORSANI, Hugo. Relações entre política e economia: Teoria da Escolha Pública. In:

BIDERMAN, Ciro; ARVATE, Paulo. (Org.). Economia do Setor Público no Brasil. Elsevier, Rio de Janeiro, $4^{\text {a }}$ tiragem. Cap. 6, p.103 - 125, 2005.

BRASIL. CIDADES (Ministério das Cidades). Manejo de Resíduos Sólidos. Disponível em: < http://www.cidades.gov.br/index.php/programas/266-residuos-solidos.html>. Acesso em 27 mar. 2014.

BRASIL. Constituição (1988). Constituição da República Federativa do Brasil. Art. 30 e 145. Brasília, DF, 5 out. 1988. Disponível em: <

http://www.planalto.gov.br/ccivil_03/constituicao/constituicao.htm> Acesso em: 24 jan. 2014

BRASIL. Decreto ${ }^{\circ}$ 6.017, de 17 de janeiro de 2007. Regulamenta a Lei no 11.107 , de 06 de abril de 2005, que dispõe sobre normas gerais de contratação de consórcios públicos. Diário Oficial [da] República Federativa do Brasil. Brasília, DF, 17 jan. 2007a. Disponível em: <http://www.planalto.gov.br/ccivil_03/_ato2007-2010/2007/decreto/d6017.htm>. Acesso em: 07 jun. 2014.

BRASIL. Decreto $n^{\circ} 7.404$, de 23 de dezembro de 2010. Regulamenta a Lei $\mathrm{n}^{\circ}$ 12.305. Diário Oficial [da] República Federativa do Brasil, 2010b. Disponível em: http://www.planalto.gov.br/ccivil_03/_ato2007-2010/2010/Decreto/D7404.htm. Acesso em: 12 fev. 2014.

BRASIL. Decreto n ${ }^{\circ} 7.217$, de 21 de junho de 2010. Regulamenta a Lei no 11445 . Diário Oficial [da] República Federativa do Brasil, 2010c. Disponível em: <http://www.planalto.gov.br/ccivil_03/_ato2007-2010/2010/Decreto/D7217.htm>. Acesso em: 12 fev. 2014. 
BRASIL. FUNASA (Fundação Nacional de Saúde). Critérios e Procedimentos para Aplicações de Recursos Financeiros. Disponível em: < http://www.funasa.gov.br/site/convenios/engenharia-de-saude-publica/. Acesso em: 23 mar 2014ạ.

BRASIL. FUNASA (Fundação Nacional de Saúde). Manual de Orientações Técnicas para o Programa de Resíduos Sólidos Urbanos. Disponível em:

$<$ http://www.funasa.gov.br/site/convenios/orientacoes-tecnicas-de-saneamento/>. Acesso em: 23 mar 2014b.

BRASIL. Instituto Brasileiro de Geografia e Estatística (IBGE). Censo Demográfico 2010. IBGE Cidades. Disponível em: < http://cidades.ibge.gov.br/xtras/home.php>. Acesso em: 13 jun. 2014.

BRASIL. Instituto Brasileiro de Geografia e Estatística (IBGE). Pesquisa de Informações Básicas Municipais: Perfil dos municípios brasileiros 2013. Rio de Janeiro, RJ, 2014a.

BRASIL. Instituto Brasileiro de Geografia e Estatística (IBGE). Contas Nacionais. Disponível em: http://brasilemsintese.ibge.gov.br/contas-nacionais/pib-per-capita. Acesso em: 17 nov. 2014b.

BRASIL. Lei $\mathrm{n}^{\circ}$ 12.305, de 02 de agosto de 2010. Institui a Política Nacional de Resíduos Sólidos. Diário Oficial [da] República Federativa do Brasil. Brasília, DF, 02 ago. 2010a. Disponível em: http://www.planalto.gov.br/ccivil_03/_ato2007-2010/2010/lei/112305.htm. Acesso em: 12 fev. 2014

BRASIL. Lei $\mathrm{n}^{\circ} 11445$, de 05 de janeiro de 2007. Estabelece diretrizes nacionais para o saneamento básico. Diário Oficial [da] República Federativa do Brasil. Brasília, DF, 5 jan. 2007b. Disponível em: <http://www.planalto.gov.br/ccivil_03/_ato20072010/2007/lei/l11445.htm>. Acesso em: 12 fev. 2014

BRASIL. Lei no 11.107, de 06 de abril de 2005. Dispõe sobre normas gerais de contratação de consórcios públicos. Diário Oficial [da] República Federativa do Brasil. Brasília, DF, 06 abr. 2005. Disponível em: <http://www.planalto.gov.br/ccivil_03/_ato20042006/2005/lei/111107.htm>. Acesso em: 07 jun. 2014

BRASIL. Lei no 8.666, de 21 de junho de 1993. Art. 24 inciso XXVI. Regulamenta o art. 37, inciso XXI, da Constituição Federal, institui normas para licitações e contratos da Administração Pública. Diário Oficial [da] República Federativa do Brasil. Brasília, DF, 21 jun. 1993. Disponível em: < http://www.planalto.gov.br/ccivil_03/leis/18666cons.htm>. Acesso em: 05 jul. 2014.

BRASIL. MCTI (Ministério da Ciência, Tecnologia e Inovação). FNDCT (Fundo Nacional de Desenvolvimento Científico e Tecnológico). Informações Gerais. Disponível em:< http://www.mct.gov.br/index.php/content/view/1385/Informacoes_Gerais.html>. Acesso em: 04 jun. 2014a.

BRASIL. MCTI (Ministério da Ciência, Tecnologia e Inovação). FNDCT (Fundo Nacional de Desenvolvimento Científico e Tecnológico). Relatórios de Gestão. Disponível em:< http://www.mct.gov.br/index.php/content/view/325431/Fundo_Nacional_de_Desenvolviment o_Cientifico_e_Tecnologico_FNDCT.html>. Acesso em: 04 jun. 2014 b.

BRASIL. MCTI (Ministério da Ciência e Tecnologia). Protocolo de Quioto à Convenção sobre Mudança do Clima. O Brasil e a Convenção- Quadro das Nações Unidas. Editado e 
traduzido pelo Ministério da Ciência e Tecnologia com o apoio do Ministério das Relações Exteriores da República Federativa do Brasil, [1998].

BRASIL. MMA. Ministério do Meio Ambiente (MMA). Fundo Nacional do Meio Ambiente (FNMA). Disponível em: < http://www.mma.gov.br/apoio-a-projetos/fundo-nacional-domeio-ambiente> Acesso em: 03 jun. 2014a.

BRASIL. MMA. FNMA. Convênios FNMA 1990 a 2013-1. Disponível em: < http://www.mma.gov.br/images/arquivo/80110/Convenios\%20FNMA\%201990\%20A\%2020 13-1.pdf> Acesso em: 21 mar. 2014b.

BRASIL. MMA. FNMA. Fundo Nacional do Meio Ambiente. Editais e Termos de Referência. < http://www.mma.gov.br/apoio-a-projetos/fundo-nacional-do-meioambiente/editais-e-termos-de-referencia/item/351> Acesso em 10 jul. 2014c.

BRASIL. MMA. FNMA. Prestação de contas ordinária anual. Relatório de gestão do exercício de 2011. Março, 2012. Disponível em:

<htpp://www.mma.gov.br/images/arquivos/apoio_a_projetos/fnma/relatorios_gestao/2011.pdf >. Acesso em: 19 fev. 2014

BRASIL. MMA. Fundo Nacional sobre Mudança do Clima. Disponível em: <http://www.mma.gov.br/apoio-a-projetos/fundo-nacional-sobre-mudanca-do-clima>. Acesso em: 22 mar. 2014d.

BRASIL. MMA. Fundo Nacional sobre Mudança do Clima. Editais, chamadas e audiências públicas. Disponível em: <http://www.mma.gov.br/apoio-a-projetos/fundo-nacional-sobremudanca-do-clima/editais-chamadas-e-audiencias-publicas>. Acesso em: 04 jun. 2014e.

BRASIL. MMA. Política Nacional de Resíduos Sólidos. Disponível em: http://www.mma.gov.br/cidades-sustentaveis/residuos-solidos/politica-nacional-de-residuossolidos/linha-do-tempo. Acesso em 19 fev. $2014 \mathrm{f}$.

BRASIL. MMA. Política Nacional de Resíduos Sólidos. Disponível em: http://www.mma.gov.br/informma/item/10272-pol\%C3\%ADtica-de-res\%C3\%ADduoss\%C3\%B3lidos-apresenta-resultados-em-4-anos. Acesso em 17 nov. 2014g.

BRASIL. SICONV (Sistema de Convênios do Governo Federal). Download das Bases de Dados de Convênios do Governo Federal. Disponível em: < https://gerencialweb.convenios.gov.br/web/gerencialweb/convenios-celebrados>. Acesso em: 12 mai. 2014.

BRASIL. TCU (Tribunal de Contas da União). Relatório de Auditoria Operacional do Segundo Monitoramento no Programa Resíduos Sólidos Urbanos. Secretaria-Geral de Controle Externo/Secretaria de Fiscalização e Avaliação de Programas de Governo - Seprog, 2011.

CALDERONI, Sabetai. Os Bilhões Perdidos no Lixo. 4. ed. São Paulo: Humanitas Editora/FFLCH/USP, Cap 3, p. 53-75, 2003.

CAMPINAS. Lei Municipal nº 6.355, de 26 de dezembro de 1990. Dispõe sobre a taxa de coleta e destinação de lixo. Paço Municipal, 26 dez. 1990. Disponível em: < http://www.leismunicipais.com.br/a/sp/c/campinas/lei-ordinaria/1990/635/6355/lei-ordinaria- 
n-6355-1990-dispoe-sobre-a-taxa-de-coleta-e-destinacao-de-lixo.html>. Acesso em: 05 jun. 2014.

CAMPINAS. Lei Municipal no 9.951, de 18 de dezembro de 1998. Dá nova redação ao artigo 12 e incisos da lei 6.355, de 26 dez. 1990. Paço Municipal, 18 dez. 1998. Disponível em: <http://www.leismunicipais.com.br/a/sp/c/campinas/lei-ordinaria/1998/996/9951/leiordinaria-n-9951-1998-da-nova-redacao-ao-artigo-12-e-incisos-da-lei-no-6355-de-26-dedezembro-de-199o-que-dispoe-sobre-a-taxa-de-coleta-remocao-e-destinacao-de-lixo-alteradopelas-leis-nos-8-718-95-e-9-575-97?q=9951\%20de\%201998>. Acesso em: 05 jun. 2014.

CAMPINAS. Prefeitura Municipal de Campinas. Taxa de Lixo. Disponível em:< http://www.campinas.sp.gov.br/governo/financas/iptu/taxa-lixo.php >. Acesso em: 20 mai. 2014.

CARNEIRO, Carlos Eduardo G. Gerência Executiva da Caixa Econômica Federal, Governo de São Paulo. Comunicação pessoal. Contato telefônico em 30 mai. 2014.

CEPAM (Centro de Estudos e Pesquisas de Administração Municipal). Informativo CEPAM, São Paulo, 2014.

DASGUPTA, Partha; MÄLER, Karl-Göran. Nature's Non-Convexities. In: Environmental and Resource Economics: Some Recent Developments. Bi-Annual teaching and research workshop of the South Asian Network for Development and Environmental Economics (SANDEE).Colombo, Sri Lanka, 2004.

EIGENHEER, Emílio. M. Resíduos Sólidos como tema de educação ambiental. ComCiência, 2008. Disponível em: < http://www.oei.es/noticias/spip.php?article2150 >. Acesso em: 03 de mar. 2014.

ETHRIDGE, Don. The research problem and objectives. In: Research Methodology in Applied Economics - Organizing, Planning, and conducting Economic Research. National Academy Press, Washington, DC. Cap 6, p. 101 - 114, 1995.

EZEAH, Chukwunonye; ROBERTS, Clive L. Analysis of barriers and success factors affecting the adoption of sustainable management of municipal solid waste in Nigeria. Journal of Environmental Management, v. 103, p. 9-14, 2012.

FIELD, Barry. Criterios para evaluar las políticas ambientales. In: Economía Ambiental. Uma Introducción. Santafé de Bogotá: McGraw-Hill, 1997. Cap. 9, p. 212-223.

GHOSH, B. N. Government Failure. In: ____ From market failure to government failure: a handbook of public sector economics. University of Science Malaysia, Penang, Malaysia, Wisdom House. 2001. Cap 5, p. 267 - 273.

GUARULHOS. Lei municipal nº 6.793, de 28 de dezembro de 2010. Dispõe sobre o lançamento, arrecadação e fiscalização do imposto sobre a propriedade predial e territorial urbana - IPTU. Diário Oficial do Município de Guarulhos, Guarulhos, 29 dez. 2010. Disponível em:< http://www.leismunicipais.com.br/a/sp/g/guarulhos/leiordinaria/2010/679/6793/lei-ordinaria-n-6793-2010-dispoe-sobre-o-lancamento-arrecadacaoe-fiscalizacao-do-imposto-sobre-a-propriedade-predial-e-territorial-urbana-iptu-e-da-outrasprovidencias.html>. Acesso em: 05. Jun. 2014. 
IPEA. Instituto de Pesquisa Econômica Aplicada. Pesquisa sobre Pagamentos por Serviços Ambientais Urbanos para Gestão de Resíduos Sólidos: relatório de Pesquisa. Diretoria de Estudos e Políticas Regionais, Urbanas e Ambientais (Dirur). Brasília, 2010.

IPEA. Instituto de Pesquisa Econômica Aplicada. Diagnóstico dos Instrumentos Econômicos e Sistemas de Informação para Gestão de Resíduos Sólidos: relatório de pesquisa. Brasília, 2012.

IPECE. Instituto de Pesquisa e Estratégia Econômica do Ceará. Cartilha da Cota Parte do ICMS. Secretaria de Planejamento e Gestão, Governo do Estado do Ceará. Fortaleza, 2009.

LEITE. Francisco. Ministério das Cidades. Secretaria Nacional de Saneamento Ambiental SNSA. Comunicação pessoal. Contato telefônico em 28 mar. 2014.

LIPSEY. Richard G. Reflections on the general Theory of Second Best at its Golden jubilee (version 06). Presented to the 62nd Congresso f the International Institute of Public Finance. Bowen Island, BC, Canada, 2007.

MAGALHÃES, Teia. Manejo de resíduos sólidos: sustentabilidade e verdade orçamentária com participação popular. In: CORDEIRO, S. Berenice (coord.). Lei nacional de saneamento básico: perspectivas para as políticas e a gestão dos serviços públicos. Livro III, Prestação dos serviços públicos de Saneamento Básico. Brasília: Ministérios das Cidades, PMSS, v. 3, p. 520-529, 2009.

MARÉS, Francine I. Serviço Autônomo Municipal de Água e Esgoto - SAMAE. Comunicação pessoal. Contato telefônico em 16 mai. de 2014 e por e-mail em 15 de jul. de 2014.

MARGULIS, Sérgio. Controle Ambiental: Coisa para Rico? In: Planejamento e Políticas Públicas. Brasília: IPEA, n.7, junho de 1992.

MARTINEZ, Candance. A.; BOWEN, J.D. The Clean Development Mechanism in the Solid Waste Management Sector: Sustainable for Whom? Ecological Economics, v. 82, p. 123-125, 2012.

MENDES, Constantino C. Arranjos Federativos e Desigualdades Regionais no Brasil. In: IPEA, Brasil em Desenvolvimento 2013: Estado, Planejamento e Políticas Públicas. Volume 1. Brasília, Ipea, 2013. Cap. 7, p. 199- 220.

MENDES, Marcos. Por que a intervenção do governo pode gerar prejuízos à sociedade? Brasil, Economia e Governo, publicado em maio 2011. Disponível em: < http://www.brasileconomia-governo.org.br/2011/05/05/por-que-a-intervencao-do-governo-pode-gerarprejuizos-a-sociedade/>. Acesso em: 30 mai. 2014.

MENEZES, Rafael T. et al. Viabilidade Econômica da construção e implementação de aterros sanitários: vantagens de modelos com Consórcios municipais, subsídios federais e operação pública ou privada. CITAR - FUNDACE, 2012.

MILLER. Miriam. Gerência do Fundo Nacional do Meio Ambiente. Comunicação pessoal. Entrevistas concedidas em 28 mar. 2014 e 11 abr. 2014. 
MORENO-SÁNCHEZ, Rocío P.; MALDONADO, Jorge H. Surviving from garbage: the role of informal waste-pickers in a dynamic model of solid waste management in developing countries. Environment and Development Economics, v. 11, p 371- 391, 2006.

MUELLER, Charles C. Os economistas e as relações entre o sistema econômico e o meio ambiente. Brasília. Editora Universidade de Brasília, 2012. 562 p. 1ª reimpressão.

NAHMAN, A.; GODFREY, L. Economic instruments for solid waste management in South Africa: Opportunities and constraints. Resources, Conservation and Recycling, v. 54, p. 521$531,2010$.

NASCIMENTO NETO, Paulo; MOREIRA, Tomás. A. Consórcio intermunicipal como instrumento de gestão de resíduos sólidos urbanos em regiões metropolitanas: reflexões teórico-conceituais. Revista Brasileira de Gestão e Desenvolvimento Regional (G\&DR), Taubaté, SP, Brasil, v. 8, n. 3, p. 239 - 282, 2012.

NOGUEIRA, Jorge M.; PEREIRA, Romilson R. Critérios e Análise Econômicos na Escolha de Políticas Ambientais. ECO-NEPAMA, Brasília, [1999].

PALMER, Karen; WALLS, Margaret. Optimal policies for solid waste disposal: taxes, subsidies, and standards. Jornal of Public Economics, v. 65, p 193-205, 1997.

PERMAN, Roger et al. Market Failure and Public Policy. In___ Natural Resource and Environmental Economics. Essex, Inglaterra: Longman, 2a Edição, p. 127-149, 1999.

PEQUENO, Pedro Alexandre M. A Inclusão das ações de regulação na gestão regionalizada dos resíduos sólidos nos estados do Rio de Janeiro. Artigo apresentado em ABAR - VIII Congresso Brasileiro de Regulação, 2013.

PORTER, Richard C. The Economics of Waste. RFF Press, Washington DC, 2002. 301 p.

PERNAMBUCO. Decreto $n^{\circ} 23.473$, de 10 de agosto de 2001. Regulamenta os critério de distribuição da parcela do ICMS que cabe aos Municípios, relativos aos aspectos sócioambientais. Disponível em: < http://www.icmsecologico.org.br/images/legislacao/leg024.pdf>. Acesso em: 05 jun. 2014.

PERNAMBUCO. Governo do Estado de Pernambuco. Regionalização da Gestão de resíduos sólidos de Pernambuco. In: Plano Estadual de Resíduos Sólidos. Secretaria de Meio Ambiente e Sustentabilidade - SEMAS. ITEP (Instituto de Tecnologia de Pernambuco). Cap. 02, p. 199 $-220,2012$.

PINDYCK, Robert. S.; RUBINFELD, Daniel L. Custos de Produção. In:

Microeconomia. Tradução e revisão técnica: Professor Eleutério Prado. $5^{\mathrm{a}}$ edição. São Paulo: Prentice Hall, Cap. 7, p. 201-248, 2002.

PNUD (Programa das Nações Unidas para o Desenvolvimento). Estudo sobre o Potencial de geração de energia a partir de resíduos de Saneamento (lixo, esgoto), visando incrementar o uso de biogás como fonte alternativa de energia renovável - Resumo Executivo. São Paulo: MMA; PNUD, 2010, Arcadis. Tetraplan. 
PRETTE, Marcos Del. Gerência de Projeto, Secretaria de Mudanças Climáticas e Qualidade Ambiental. Comunicação Pessoal. Resposta - SIC MMA/653 obtida em 22 mai. 2014 pelo Serviço de Informação ao Cidadão - SIC.

RIBEIRO, Wladimir A. Cooperação Federativa e a Lei de Consórcios Públicos. Brasília DF:CNM, 2007.

ROURA, Juan R. C. La Elaboración de la Política Económica. In : Introducción a la

Política Económica. Universidad de Alcalá. McGraw-Hill. Cap 4, p 99 - 132, 1997.

SCHNEIDER, M. Dan. et al. Orientações básicas para a gestão consorciada de resíduos sólidos. Inovação na Gestão Pública. Cooperação Brasil-Alemanha. Editora IABS, Brasília, 2013.

SNIS (Sistema Nacional de Informações sobre Saneamento). Diagnóstico do manejo de resíduos sólidos urbanos - 2011. Ministério das Cidades, Secretaria Nacional de Saneamento Ambiental. Brasília, p. 82-88, 2013.

SOUZA. Celina. Políticas Públicas: uma revisão da literatura. Sociologias, Porto Alegre. Ano $8, \mathrm{n}^{\circ} 16$, p. 20-45, 2006.

STERNER, Thomas; CORIA, Jessica. Policy Instruments for Environmental and Natural Resource Management. 2. ed. New York: RFF Press, cap. 24, p 445-459, 2012.

UNEP (United Nations Environment Programme). The use of Economic Instruments for Environmental and Natural Resource Management. Training Resource Materials. 1 ${ }^{\mathrm{a}}$ edição, 2009.

VENDA NOVA DO IMIGRANTE, Projeto de Lei no 045, de 15 de agosto de 2011. Câmara Municipal de Venda Nova do Imigrante, Espírito Santo, 15 ago. 2011. Disponível em: < http://www.camaravni.es.gov.br/SNO/SPL/documentos/PL\%200452011\%20CLJRF0001.pdf>. Acesso em: 05 jun. 2014.

WAGNER, Jeffrey. Incentivizing sustainable waste management. Ecological Economics, v 70, p. 585-594, 2011. 


\section{APÊNDICE A - Questionário aplicado aos Fundos FNMA, FNDCT, Fundo Clima e Funasa}

1) De onde vêm os recursos do Fundo?

2) A listagem do relatório de convênios disponibilizada no site que relaciona os projetos de 1990 a 2013 são o total dos convênios da demanda espontânea e induzida juntos?

( ) Sim ( ) Não, só de demanda espontânea ( ) Não, só de demanda induzida

3) Desde a criação do Fundo, quantas vezes a gestão de resíduos sólidos foi tema da demanda espontânea e dos editais e termos de referência da demanda induzida? E em quais anos?

4) De acordo com o relatório de convênios, entre 1990 a 2012 o FNMA realizou 100 projetos com as prefeituras municipais na área de gestão de resíduos sólidos urbanos nas categorias de gestão integrada de resíduos sólidos, qualidade ambiental e sociedades sustentáveis. No entanto, observa-se uma redução no número de projetos e consequentemente um aumento dos recursos do FNMA aos projetos. Esta redução tem relação com a estratégia do Fundo de a partir de 2009 reduzir o número de projetos financiados com o intuito de melhorar o acompanhamento dos mesmos?
( ) $\operatorname{Sim}$
( ) Não [ informe o motivo]

5) Mesmo com a estratégia de redução de projetos beneficiados, há expectativa ou planos para que sendo o FNMA um instrumento da lei da Política Nacional de Resíduos Sólidos que o número de projetos e valor dedicado à gestão de resíduos sólidos aumente?

( ) Sim [ Informe os planos]

( ) Não. [Informe o motivo]

6) Quais os critérios avaliados para a aprovação de propostas municipais? Relacione em ordem de prioridade, sendo o 1, o mais importante.

( ) População do Município

[qual a preferência]

( ) 1 a 20.000

( ) 20.000 a 50.000

( ) 50.000 a 100.000

( ) 100.000 a 120.000

( ) acima de 120.000

( ) não é relevante 


\section{( ) Capacidade técnica de execução do Município \\ ( ) Capacidade de cumprir com o valor de contra partida \\ ( ) Deficiência nos serviços públicos de gestão de resíduos sólidos}

\section{( ) Outros [ informe]}

7) O Consórcio Público é um instrumento da PNRS, e sua conformação é incentivada pela referida lei. O Fundo já financiou 4 projetos para Consórcios intermunicipais para gestão de resíduos sólidos, o Fundo possui alguma estratégia para que aumente o financiamento de projetos para este tipo de arranjo institucional?

( ) Sim. [ informe qual]

( ) Não

8) Gostaria de relatar alguma informação importante relacionada a participação do FNMA no fomento da gestão de resíduos sólidos urbanos no país a partir da PNRS?

\section{Fundo Nacional de Desenvolvimento Científico e Tecnológico - FNDCT}

1) Como o FNDCT tem atuado como instrumento da PNRS. Se há projetos desenvolvidos ou em desenvolvimento no setor de resíduos sólidos que corroborem com o especificado na lei. Se a resposta for não, gostaria de saber se há projeções futuras para inserir o setor como beneficiador do Fundo e como isso poderia ser feito.

2) Os pequenos municípios apresentam estrutura municipal deficitária na parte técnica e de recursos humanos na área de gestão de resíduos sólidos e Consórcios Públicos, O FNDCT poderia ser uma fonte de financiamento para capacitação e formação técnica para estes municípios? Como isto poderia ser feito?

\section{Fundo Nacional sobre Mudança do Clima - Fundo Clima}

1) O Fundo Clima possui projetos voltados para o setor de resíduos sólidos para gestão municipal e gestão via Consórcios Públicos?

2) Se não possui, se há projeções futuras para incluir o setor nas demandas do Fundo?

3) A Política Nacional de Resíduos Sólidos (lei 12.305,2010) alterou ou pode alterar as demandas do Fundo?

4) Como o Fundo Clima poderia auxiliar os pequenos municípios e os Consórcios Públicos em gestão de resíduos sólidos para a mitigação dos gases gerados nos aterros sanitários?

\section{FUNASA}

1) Qual a fonte financiadora dos recursos da FUNASA para o financiamento dos Programas de Resíduos Sólidos Urbanos?

2) Existem relatórios com dados (nome do Município, finalidade do financiamento e valor) de todos os Programas de Resíduos Sólidos já financiados pela FUNASA? ( ) Sim. 
[Os relatórios podem ser disponibilizados para a pesquisa?] ( ) sim ( ) não

( ) Não.

3) Existem relatórios com os orçamentos planejados e os executados dos Programas de Resíduos Sólidos Urbanos da FUNASA?

( ) Sim.

[Se sim, os relatórios podem ser disponibilizados para a pesquisa?] ( ) sim ( ) não

( ) Não.

4) O Programa atual de Resíduos Sólidos Urbanos da FUNASA faz parte da ação orçamentária 10GG do Plano Plurianual 2012-2015?

( ) $\operatorname{Sim}$

( ) Não

5) Quando a última seleção foi aberta e quando foi encerrada?

6) Existe uma relação dos Municípios e Consórcios Públicos beneficiados da última seleção?

( ) Sim.

[Se sim, a relação pode ser disponibilizada para a pesquisa?] ( ) $\operatorname{sim}$ ( ) não

( ) Não.

7) O Programa de Resíduos Sólidos da FUNASA engloba o financiamento para os sistemas de coleta, tratamento e destinação final de resíduos sólidos, qual categoria é mais financiada? [Sendo 1 a mais financiada e 4 a menos]

( ) Acondicionamento, coleta e transporte;

( ) Unidades de disposição final - aterros sanitários ou de rejeitos;

( ) Unidades de tratamento - triagem e/ou compostagem.

( ) Erradicação de 'lixões e recuperação de áreas degradadas.

8) Que mudanças no financiamento ocorreram após a lei da Política Nacional de Resíduos Sólidos?

( ) É condição primária os município possuírem o Plano Municipal de Gestão Integrada de Resíduos Sólidos;

( ) Prioridade no acesso aos recursos para Consórcio Público de Saneamento ou de Resíduos Sólidos

( ) Outros [ informar]

( ) Não houve alterações nas regras de financiamento.

9) Quais impactos da lei da Política Nacional de Resíduos Sólidos no financiamento dos Programas de Resíduos Sólidos da FUNASA?

( ) Positivos [ relatar quais]

( ) Negativos [ relatar quais]

10) O foco do Programa são municípios com população de até 50.000 habitantes, município pertencente à região metropolitana ou RIDE e Consórcios Públicos. De acordo com o Manual de Orientações Técnicas para Elaboração de Propostas para o Programa de Resíduos Sólidos Urbanos - FUNASA, pertencer a um Consórcio Público 
é prioridade no acesso aos recursos. Pela experiência em curso, o incentivo de acesso a recursos tem sido um motivador para os municípios na conformação dos Consórcios Públicos para a gestão de resíduos sólidos?

( ) Sim.

( ) Não.

( ) Os Consórcios Públicos só passaram a ser prioridade após a Lei da Política Nacional de Resíduos Sólidos à partir do Programa do Ano [ informar o ano]

11) Para que um Consórcio Público seja elegível para o financiamento, ele precisa:

( ) Possuir população total dos municípios integrantes de até [ informar]

( ) Possuir uma quantidade mínima de municípios integrantes do Consórcio [informar quantidade]

12) O Programa atual exige uma comprovação de auto sustentação dos serviços financiados para que os municípios e/ ou Consórcios consigam manter os serviços após o financiamento?

( ) Sim

( ) Instituição de taxa (cobrança pelos serviços de resíduos sólidos)

( ) benefício do ICMS Ecológico

( ) Outros [ informar]

( ) Não

13) A FUNASA possui algum mecanismo de monitoramento ou acompanhamento de que serviços solicitados do financiamento foram realizados?

14) Nas experiências em curso, quais as principais dificuldades dos Municípios para apresentar propostas e serem elegíveis para o financiamento?

15)E para os Consórcios Públicos, quais os gargalos encontrados?

16) Gostaria de relatar alguma informação importante relacionada a participação da FUNASA no fomento da gestão de resíduos sólidos urbanos no país? 


\section{APÊNDICE B - Tabela elaborada com base no Relatório de Convênios 1990-2013 dos projetos do FNMA para resíduos sólidos}

Relatório dos convênios realizados pelo FNMA entre 1990-2012 nas categorias de gestão integrada de resíduos sólidos, qualidade ambiental e sociedades sustentáveis na esfera municipal ${ }^{39}$

\begin{tabular}{|c|c|c|c|c|c|c|c|c|c|c|c|}
\hline & Ano & $\mathrm{nCV}$ & Tema & Instituição Convenente & Título do Projeto & UF & $\begin{array}{c}\text { Esfera } \\
\text { Institucional }\end{array}$ & $\begin{array}{l}\text { Recurso do } \\
\text { FNMA (R\$) }\end{array}$ & $\begin{array}{l}\text { Recursos de } \\
\text { Contra } \\
\text { Partida (R\$) }\end{array}$ & $\begin{array}{l}\text { Valor Total } \\
\text { do Projeto } \\
\text { (R\$) }\end{array}$ & $\begin{array}{l}\text { Popul } \\
\text { ação } \\
\text { Censo } \\
2010^{40}\end{array}$ \\
\hline 1 & 1994 & Cv032/94 & Gestão Integrada de Resíduos Sólidos & $\begin{array}{l}\text { Prefeitura Municipal de } \\
\text { Diamantina }\end{array}$ & $\begin{array}{l}\text { Soluções Tecnológicas para o sistema } \\
\text { de coleta do lixo }\end{array}$ & MG & Municipal & 64.952 & 31.645 & 96.597 & 45.880 \\
\hline 2 & 1994 & Cv038/94 & Gestão Integrada de Resíduos Sólidos & $\begin{array}{l}\text { Prefeitura Municipal de Nova } \\
\text { Prata }\end{array}$ & $\begin{array}{l}\text { Implantação de Melhorias na Central } \\
\text { de Reciclagem e Compostagem de } \\
\text { lixo } \\
\end{array}$ & RS & Municipal & 232.951 & 130.510 & 363.461 & 23.830 \\
\hline 3 & 1995 & Cv020/95 & Gestão Integrada de Resíduos Sólidos & $\begin{array}{l}\text { Prefeitura Municipal de } \\
\text { Saudades }\end{array}$ & $\begin{array}{l}\text { Controle, Manejo e utilização de } \\
\text { dejetos }\end{array}$ & SC & Municipal & 15.209 & 5.563 & 20.772 & 9.016 \\
\hline 4 & 1995 & Cv040/95 & Gestão Integrada de Resíduos Sólidos & $\begin{array}{l}\text { Prefeitura Municipal de } \\
\text { Paraíso do Norte }\end{array}$ & Aterro Sanitário & $P R$ & Municipal & 55.865 & 69.110 & 124.975 & 11.772 \\
\hline 5 & 1995 & Cv052/95 & Gestão Integrada de Resíduos Sólidos & $\begin{array}{l}\text { Prefeitura Municipal de } \\
\text { Balneário Camboriú }\end{array}$ & Coleta seletiva de lixo & SC & Municipal & 126.818 & 38.045 & 164.863 & 108.926 \\
\hline 6 & 1995 & Cv089/95 & Gestão Integrada de Resíduos Sólidos & $\begin{array}{l}\text { Prefeitura Municipal de Alto } \\
\text { Paraíso }\end{array}$ & Coleta seletiva de lixo & $\mathrm{GO}$ & Municipal & 179.777 & 53.935 & 233.712 & 6.885 \\
\hline 7 & 1998 & Cv002/98 & Gestão Integrada de Resíduos Sólidos & $\begin{array}{l}\text { Prefeitura Municipal de } \\
\text { Paranaguá }\end{array}$ & $\begin{array}{l}\text { Coleta, triagem, armazenamento e } \\
\text { remoção do lixo da llha do Mel }\end{array}$ & PR & Municipal & 62.762 & 29.500 & 92.262 & 140.469 \\
\hline 8 & 2000 & Cv017/00 & Gestão Integrada de Resíduos Sólidos & $\begin{array}{l}\text { Prefeitura Municipal de } \\
\text { Chapadinha }\end{array}$ & $\begin{array}{l}\text { Gerenciamento Integrado de resíduos } \\
\text { sólidos }\end{array}$ & MA & Municipal & 299.402 & 70.668 & 370.070 & 73.350 \\
\hline 9 & 2000 & Cv022/00 & Gestão Integrada de Resíduos Sólidos & Prefeitura Municipal de Irati & $\begin{array}{l}\text { Plano de Gerenciamento Integrado } \\
\text { dos Resíduos Sólidos Urbanos }\end{array}$ & PR & Municipal & 222.970 & 59.968 & 282.938 & 56.207 \\
\hline 10 & 2000 & Cv024/00 & Gestão Integrada de Resíduos Sólidos & $\begin{array}{l}\text { Prefeitura Municipal de } \\
\text { Campo Belo }\end{array}$ & Campo Belo, Limpo e Saudável & MG & Municipal & 349.985 & 202.865 & 552.850 & 51.544 \\
\hline 11 & 2000 & Cv026/00 & Gestão Integrada de Resíduos Sólidos & $\begin{array}{l}\text { Prefeitura Municipal de } \\
\text { Petrolândia }\end{array}$ & Plano de Gestão de Resíduos Sólidos & $\mathrm{PE}$ & Municipal & 296.480 & 46.387 & 342.867 & 32.492 \\
\hline
\end{tabular}

\footnotetext{
${ }^{39}$ Fonte: FNMA. Convênios FNMA 1990 a 2013-1. Disponível em: < http://www.mma.gov.br/images/arquivo/80110/Convenios\%20FNMA\%201990\%20A\%202013-1.pdf> Acesso em:21 mar. 2014b.

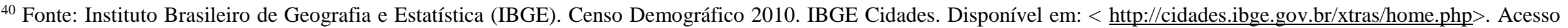
em: 13 jun. 2014.
} 


\begin{tabular}{|c|c|c|c|c|c|c|c|c|c|c|c|}
\hline & Ano & $\mathrm{n} \mathrm{CV}$ & Tema & Instituição Convenente & Título do Projeto & UF & $\begin{array}{c}\text { Esfera } \\
\text { Institucional } \\
\end{array}$ & $\begin{array}{l}\text { Recurso do } \\
\text { FNMA (R\$) }\end{array}$ & $\begin{array}{l}\text { Recursos de } \\
\text { Contra } \\
\text { Partida (R\$) }\end{array}$ & $\begin{array}{l}\text { Valor Total } \\
\text { do Projeto } \\
\text { (R\$) }\end{array}$ & $\begin{array}{c}\text { Populaçã } \\
\text { o Censo } \\
2010 \\
\end{array}$ \\
\hline 12 & 2000 & Cv029/00 & Gestão Integrada de Resíduos Sólidos & $\begin{array}{l}\text { Prefeitura Municipal de Xique- } \\
\text { Xique }\end{array}$ & $\begin{array}{l}\text { Plano de Gerenciamento Integrado de } \\
\text { Resíduos Sólidos }\end{array}$ & BA & Municipal & 299.402 & 70.668 & 370.070 & 45.536 \\
\hline 13 & 2000 & Cv031/00 & Gestão Integrada de Resíduos Sólidos & $\begin{array}{l}\text { Prefeitura Municipal de Barra } \\
\text { do Garças }\end{array}$ & $\begin{array}{l}\text { Coleta e disposição de resíduos } \\
\text { sólidos }\end{array}$ & MT & Municipal & $282.360,70$ & $198.511,86$ & $480.872,56$ & 56.560 \\
\hline 14 & 2000 & Cv33/00 & Gestão Integrada de Resíduos Sólidos & $\begin{array}{l}\text { Prefeitura Municipal de } \\
\text { Paracatu }\end{array}$ & $\begin{array}{l}\text { Plano de Gerenciamento Integrado de } \\
\text { Resíduos Sólidos e implantação do } \\
\text { aterro sanitário }\end{array}$ & MG & Municipal & 186.576 & 205.677 & 392.253 & 84.718 \\
\hline 15 & 2000 & $\mathrm{Cv} 34 / 00$ & Gestão Integrada de Resíduos Sólidos & $\begin{array}{l}\text { Prefeitura Municipal de Nova } \\
\text { Odessa }\end{array}$ & Gestão Integrada de resíduos sólidos & SP & Municipal & 272.540 & 317.800 & 590.340 & 51.242 \\
\hline 16 & 2000 & Cv35/00 & Gestão Integrada de Resíduos Sólidos & $\begin{array}{l}\text { Prefeitura Municipal de } \\
\text { Pombal }\end{array}$ & $\begin{array}{l}\text { Plano de gestão integrada de resíduos } \\
\text { sólidos }\end{array}$ & PB & Municipal & 291.500 & 61.000 & 352.500 & 32.110 \\
\hline 17 & 2000 & $\mathrm{Cv} 36 / 00$ & Gestão Integrada de Resíduos Sólidos & $\begin{array}{l}\text { Prefeitura Municipal de } \\
\text { Breves }\end{array}$ & $\begin{array}{l}\text { Gestão participativa da limpeza } \\
\text { urbana- edital 02/2000 - resíduos } \\
\text { sólidos }\end{array}$ & PA & Municipal & 341.676 & 216.285 & 557.961 & 92.860 \\
\hline 18 & 2000 & $\mathrm{Cv} 38 / 00$ & Gestão Integrada de Resíduos Sólidos & Prefeitura Municipal de caeté & $\begin{array}{l}\text { Plano de Gerenciamento Integrado de } \\
\text { Resíduos Sólidos e implantação do } \\
\text { aterro sanitário }\end{array}$ & MG & Municipal & 281.574 & 59.469 & 341.043 & 40.750 \\
\hline 19 & 2000 & Cv039/00 & Gestão Integrada de Resíduos Sólidos & $\begin{array}{l}\text { Prefeitura Municipal de } \\
\text { lagarto }\end{array}$ & $\begin{array}{l}\text { Aterro Sanitário para Lagarto: Saúde } \\
\text { para Todos- edital 02/2000 - resíduos } \\
\text { sólidos }\end{array}$ & SE & Municipal & 300.000 & 217.010 & 517.010 & 94.861 \\
\hline 20 & 2000 & Cv041/00 & Gestão Integrada de Resíduos Sólidos & $\begin{array}{l}\text { Prefeitura Municipal de } \\
\text { Mirassol D'oeste }\end{array}$ & $\begin{array}{l}\text { Plano de Gerenciamento Integrado de } \\
\text { Resíduos Sólidos }\end{array}$ & MT & Municipal & 253.463 & 25.016 & 278.479 & 25.299 \\
\hline 21 & 2000 & Cv042/00 & Gestão Integrada de Resíduos Sólidos & $\begin{array}{l}\text { Prefeitura Municipal de } \\
\text { Itabirito }\end{array}$ & $\begin{array}{l}\text { Plano de Gerenciamento Integrado } \\
\text { dos Resíduos Sólidos Urbanos e } \\
\text { Implantação de aterro sanitário }\end{array}$ & MG & Municipal & 327.720 & 139.699 & 467.419 & 45.449 \\
\hline 22 & 2000 & Cv046/00 & Gestão Integrada de Resíduos Sólidos & $\begin{array}{l}\text { Prefeitura Municipal de } \\
\text { Pacatuba }\end{array}$ & $\begin{array}{l}\text { Coleta e disposição final adequada de } \\
\text { resíduos sólidos }\end{array}$ & $\mathrm{CE}$ & Municipal & $160.394,40$ & $23.921,60$ & 184.316 & 72.299 \\
\hline 23 & 2000 & Cv055/00 & Gestão Integrada de Resíduos Sólidos & $\begin{array}{l}\text { Prefeitura Municipal de } \\
\text { Monte Carmelo }\end{array}$ & $\begin{array}{l}\text { Monte Carmelo Joga Limpo - edital } \\
02 / 2000\end{array}$ & MG & Municipal & 229.000 & 132.300 & 361.300 & 45.772 \\
\hline 24 & 2000 & Cv062/00 & Gestão Integrada de Resíduos Sólidos & Prefeitura Municipal de Irecê & Gerenciamento de Resíduos Sólidos & BA & Municipal & 297.732 & 76.668 & 374.400 & 66.181 \\
\hline 25 & 2001 & $\begin{array}{l}\text { CR01243526 } \\
1 / 01\end{array}$ & Gestão Integrada de Resíduos Sólidos & $\begin{array}{l}\text { Prefeitura Municipal de } \\
\text { Ituiutaba (SAE) }\end{array}$ & $\begin{array}{l}\text { Central de tratamento de destinação } \\
\text { final de resíduos sólidos }\end{array}$ & MG & Municipal & 447.747 & 319.530 & 767.277 & 97.171 \\
\hline
\end{tabular}




\begin{tabular}{|c|c|c|c|c|c|c|c|c|c|c|c|}
\hline & Ano & $\mathrm{n} \mathrm{CV}$ & Tema & Instituição Convenente & Título do Projeto & UF & $\begin{array}{c}\text { Esfera } \\
\text { Institucional }\end{array}$ & $\begin{array}{l}\text { Recurso do } \\
\text { FNMA (R\$) }\end{array}$ & $\begin{array}{l}\text { Recursos de } \\
\text { Contra } \\
\text { Partida (R\$) }\end{array}$ & $\begin{array}{l}\text { Valor Total } \\
\text { do Projeto } \\
\text { (R\$) }\end{array}$ & $\begin{array}{l}\text { Populaçã } \\
\text { o Censo } \\
2010 \\
\end{array}$ \\
\hline 26 & 2001 & $\begin{array}{l}\text { CR01243537 } \\
5 / 01\end{array}$ & Gestão Integrada de Resíduos Sólidos & $\begin{array}{l}\text { Prefeitura Municipal de Três } \\
\text { Pontas (SAAE) }\end{array}$ & $\begin{array}{l}\text { Elaboração do plano de } \\
\text { gerenciamento integrado de resíduos } \\
\text { sólidos urbanos e implantação do } \\
\text { aterro sanitário de Três Pontas }\end{array}$ & MG & Municipal & 200.711 & 80.389 & 281.100 & 53.860 \\
\hline 27 & 2001 & $\begin{array}{l}\text { CR01241966 } \\
\text { 0/01 }\end{array}$ & Gestão Integrada de Resíduos Sólidos & Prefeitura Municipal de Lapa & $\begin{array}{l}\text { Elaboração do plano de } \\
\text { gerenciamento integrado de resíduos } \\
\text { sólidos urbanos e implantação do } \\
\text { aterro sanitário para o município da } \\
\text { Lapa }\end{array}$ & $\mathrm{PR}$ & Municipal & 356.781 & 92.245 & 449.026 & 44.932 \\
\hline 28 & 2001 & $\begin{array}{l}\text { CR10242002 } \\
1 / 01\end{array}$ & Gestão Integrada de Resíduos Sólidos & $\begin{array}{l}\text { Prefeitura Municipal de Santa } \\
\text { Cruz do Capibaribe }\end{array}$ & $\begin{array}{l}\text { Santa Cruz do Capibaribe, respeito ao } \\
\text { Meio Ambiente. }\end{array}$ & $\mathrm{PE}$ & Municipal & 399.176 & 45.000 & 444.176 & 87.582 \\
\hline 29 & 2001 & $\begin{array}{l}\text { CR01261654 } \\
2 / 01\end{array}$ & Gestão Integrada de Resíduos Sólidos & $\begin{array}{l}\text { Prefeitura Municipal de } \\
\text { Amparo }\end{array}$ & $\begin{array}{l}\text { Projeto de gestão integrada de } \\
\text { resíduos sólidos urbanos }\end{array}$ & SP & Municipal & 383.530 & 113.146 & 496.676 & 65.829 \\
\hline 30 & 2001 & $\begin{array}{l}\text { CR01241546 } \\
1 / 01\end{array}$ & Gestão Integrada de Resíduos Sólidos & $\begin{array}{l}\text { Prefeitura Municipal de Brejo } \\
\text { Santo }\end{array}$ & $\begin{array}{l}\text { Gestão integrada de resíduos sólidos } \\
\text { urbanos }\end{array}$ & $\mathrm{CE}$ & Municipal & 396.740 & 53.260 & 450.000 & 45.193 \\
\hline 31 & 2001 & $\begin{array}{l}\text { CR01241864 } \\
4 / 01\end{array}$ & Gestão Integrada de Resíduos Sólidos & $\begin{array}{l}\text { Prefeitura Municipal de } \\
\text { Araripina }\end{array}$ & Araripina, Uma mina de limpeza. & $\mathrm{PE}$ & Municipal & 401.576 & 47.000 & 448.576 & 77.302 \\
\hline 32 & 2001 & $\begin{array}{l}\text { CR01241875 } \\
9 / 01\end{array}$ & Gestão Integrada de Resíduos Sólidos & Prefeitura Municipal de Assis & $\begin{array}{l}\text { Implantação do programa de coleta } \\
\text { seletiva lixo domiciliar no município } \\
\text { de Assis/SP }\end{array}$ & SP & Municipal & $548.511,48$ & $109.702,29$ & $658.213,77$ & 95.144 \\
\hline 33 & 2001 & $\begin{array}{l}\text { CR01241897 } \\
7 / 01\end{array}$ & Gestão Integrada de Resíduos Sólidos & $\begin{array}{l}\text { Prefeitura Municipal de Capão } \\
\text { da Canoa }\end{array}$ & $\begin{array}{l}\text { Complexo para o manejo de resíduos } \\
\text { sólidos urbanos }\end{array}$ & RS & Municipal & 348.771 & 92.583 & 441.354 & 42.040 \\
\hline 34 & 2001 & $\begin{array}{l}\text { CR01241900 } \\
4 / 01\end{array}$ & Gestão Integrada de Resíduos Sólidos & $\begin{array}{l}\text { Prefeitura Municipal de } \\
\text { Cascavel }\end{array}$ & $\begin{array}{l}\text { Gerenciamento Integrado dos } \\
\text { Resíduos Sólidos Urbanos e } \\
\text { Implantação de aterro sanitário }\end{array}$ & $\mathrm{CE}$ & Municipal & 188.575 & 21.543 & 210.118 & 66.142 \\
\hline 35 & 2001 & $\begin{array}{l}\text { CR01241911 } \\
8 / 01\end{array}$ & Gestão Integrada de Resíduos Sólidos & $\begin{array}{l}\text { Prefeitura Municipal de } \\
\text { Caxambu }\end{array}$ & $\begin{array}{l}\text { Gestão de resíduos sólidos do } \\
\text { município de Caxambu }\end{array}$ & MG & Municipal & 192.553 & 78.035 & 270.588 & 21.705 \\
\hline 36 & 2001 & $\begin{array}{l}\text { CR01241922 } \\
2 / 01\end{array}$ & Gestão Integrada de Resíduos Sólidos & $\begin{array}{l}\text { Prefeitura Municipal de } \\
\text { Charqueadas }\end{array}$ & $\begin{array}{l}\text { Complexo da unidade de tratamento } \\
\text { de resíduos sólidos urbanos }\end{array}$ & RS & Municipal & $388.072,53$ & 139.755 & $527.827,53$ & 35.320 \\
\hline 37 & 2001 & $\begin{array}{l}\text { CR01241933 } \\
6 / 01\end{array}$ & Gestão Integrada de Resíduos Sólidos & $\begin{array}{l}\text { Prefeitura Municipal de } \\
\text { Concórdia }\end{array}$ & $\begin{array}{l}\text { Plano de Gerenciamento Integrado } \\
\text { dos Resíduos Sólidos Urbanos }\end{array}$ & $\mathrm{SC}$ & Municipal & 450.000 & 311.592 & 761.592 & 68.621 \\
\hline 38 & 2001 & $\begin{array}{l}\text { CR01241944 } \\
\text { 0/01 }\end{array}$ & Gestão Integrada de Resíduos Sólidos & $\begin{array}{l}\text { Prefeitura Municipal de } \\
\text { Goianésia }\end{array}$ & $\begin{array}{l}\text { Plano de Gerenciamento Integrado } \\
\text { dos Resíduos Sólidos Urbanos }\end{array}$ & $\mathrm{GO}$ & Municipal & 416.167 & 166.484 & 582.651 & 59.549 \\
\hline
\end{tabular}




\begin{tabular}{|c|c|c|c|c|c|c|c|c|c|c|c|}
\hline & Ano & $\mathrm{n} \mathrm{CV}$ & Tema & Instituição Convenente & Título do Projeto & UF & $\begin{array}{c}\text { Esfera } \\
\text { Institucional }\end{array}$ & $\begin{array}{l}\text { Recurso do } \\
\text { FNMA (R\$) }\end{array}$ & $\begin{array}{l}\text { Recursos de } \\
\text { Contra } \\
\text { Partida (R\$) }\end{array}$ & $\begin{array}{l}\text { Valor Total } \\
\text { do Projeto } \\
\text { (R\$) }\end{array}$ & $\begin{array}{l}\text { Populaçã } \\
\text { o Censo } \\
2010 \\
\end{array}$ \\
\hline 39 & 2001 & $\begin{array}{l}\text { CR01241955 } \\
\text { 6/01 } \\
\end{array}$ & Gestão Integrada de Resíduos Sólidos & $\begin{array}{l}\text { Prefeitura Municipal de João } \\
\text { Monlevade }\end{array}$ & $\begin{array}{l}\text { Gestão municipal dos resíduos sólidos } \\
\text { dos municípios de João Monlevade, } \\
\text { rio Piracicaba e bela vista de minas. }\end{array}$ & MG & Municipal & 396.874 & 188.408 & 585.282 & 73.610 \\
\hline 40 & 2001 & $\begin{array}{l}\text { CR01241977 } \\
4 / 01 \\
\end{array}$ & Gestão Integrada de Resíduos Sólidos & $\begin{array}{l}\text { Prefeitura Municipal de } \\
\text { Moreno }\end{array}$ & Limpeza e desenvolvimento turístico & $\mathrm{PE}$ & Municipal & 399.176 & 41.000 & 440.176 & 56.696 \\
\hline 41 & 2001 & $\begin{array}{l}\text { CR01241988 } \\
8 / 01 \\
\end{array}$ & Gestão Integrada de Resíduos Sólidos & $\begin{array}{l}\text { Prefeitura Municipal de } \\
\text { Quixadá }\end{array}$ & $\begin{array}{l}\text { Projeto de gestão integrada de } \\
\text { resíduos sólidos - PGIRS }\end{array}$ & CE & Municipal & 196.025 & 22.185 & 218.210 & 80.604 \\
\hline 42 & 2001 & $\begin{array}{l}\text { CR01242024 } \\
\text { 9/01 } \\
\end{array}$ & Gestão Integrada de Resíduos Sólidos & $\begin{array}{l}\text { Prefeitura Municipal de } \\
\text { Santiago }\end{array}$ & $\begin{array}{l}\text { Gerenciamento Integrado dos } \\
\text { Resíduos Sólidos Urbanos e } \\
\text { Implantação de aterro sanitário } \\
\end{array}$ & RS & Municipal & 432.597 & 112.074 & 544.671 & 49.071 \\
\hline 43 & 2001 & $\begin{array}{l}\text { CR01261610 } \\
\text { 5/01 }\end{array}$ & Gestão Integrada de Resíduos Sólidos & Prefeitura Municipal de Bagé & $\begin{array}{l}\text { Elaboração do PGIRS, e elaboração de } \\
\text { projeto para implantação de } \\
\text { recuperação com uso de área do } \\
\text { atual lixão no município de Bagé. }\end{array}$ & RS & Municipal & 473.103 & 123.030 & 596.133 & 116.794 \\
\hline 44 & 2001 & \begin{tabular}{|l} 
CR01261632 \\
$3 / 01$ \\
\end{tabular} & Gestão Integrada de Resíduos Sólidos & $\begin{array}{l}\text { Prefeitura Municipal de } \\
\text { Erechim }\end{array}$ & $\begin{array}{l}\text { Elaboração do PGIRS, elaboração de } \\
\text { projeto executivo de aterro sanitário } \\
\text { e sua implantação e a recuperação do } \\
\text { lixão de Erechim. }\end{array}$ & RS & Municipal & 448.325 & 485.300 & 933.625 & 96.087 \\
\hline 45 & 2001 & $\begin{array}{l}\text { CR01261643 } \\
7 / 01\end{array}$ & Gestão Integrada de Resíduos Sólidos & $\begin{array}{l}\text { Prefeitura Municipal de } \\
\text { Sapiranga }\end{array}$ & $\begin{array}{l}\text { Ampliação da central de triagem e } \\
\text { compostagem de resíduos sólidos de } \\
\text { Sapiranga }\end{array}$ & RS & Municipal & 255.301 & 90.000 & 345.301 & 74.985 \\
\hline 46 & 2001 & $\begin{array}{l}\text { CR01261665 } \\
7 / 01 \\
\end{array}$ & Gestão Integrada de Resíduos Sólidos & $\begin{array}{l}\text { Prefeitura Municipal de } \\
\text { Igrejinha }\end{array}$ & $\begin{array}{l}\text { Igrejinha gerenciando seus resíduos } \\
\text { sólidos urbanos }\end{array}$ & RS & Municipal & 287.671 & 87.747 & 375.418 & 31.660 \\
\hline 47 & 2001 & \begin{tabular}{|l|} 
CR01261676 \\
$1 / 01$ \\
\end{tabular} & Gestão Integrada de Resíduos Sólidos & $\begin{array}{l}\text { Prefeitura Municipal de } \\
\text { Carazinho }\end{array}$ & $\begin{array}{l}\text { Unidade de triagem/reciclagem e } \\
\text { classificação de resíduos sólidos }\end{array}$ & RS & Municipal & $195.454,45$ & $48.863,61$ & $244.318,06$ & 59.317 \\
\hline 48 & 2001 & $\begin{array}{l}\text { CR01261687 } \\
5 / 01 \\
\end{array}$ & Gestão Integrada de Resíduos Sólidos & $\begin{array}{l}\text { Prefeitura Municipal de } \\
\text { Campo Bom }\end{array}$ & $\begin{array}{l}\text { Plano de Gerenciamento Integrado } \\
\text { dos Resíduos Sólidos do município de } \\
\text { Campo Bom }\end{array}$ & RS & Municipal & 263.432 & 70.750 & 334.182 & 60.074 \\
\hline 49 & 2001 & $\begin{array}{l}\text { CR01261698 } \\
\text { 9/01 }\end{array}$ & Gestão Integrada de Resíduos Sólidos & $\begin{array}{l}\text { Prefeitura Municipal de Santa } \\
\text { Vitória do Palmar }\end{array}$ & $\begin{array}{l}\text { Plano de Gerenciamento Integrado } \\
\text { dos Resíduos Sólidos }\end{array}$ & RS & Municipal & 547.463 & 109.515 & 656.978 & 30.990 \\
\hline
\end{tabular}




\begin{tabular}{|c|c|c|c|c|c|c|c|c|c|c|c|}
\hline & Ano & $\mathrm{ncV}$ & Tema & Instituição Convenente & Título do Projeto & UF & $\begin{array}{c}\text { Esfera } \\
\text { Institucional } \\
\end{array}$ & $\begin{array}{l}\text { Recurso do } \\
\text { FNMA (R\$) }\end{array}$ & $\begin{array}{c}\text { Recursos de } \\
\text { Contra } \\
\text { Partida (R\$S) } \\
\end{array}$ & $\begin{array}{l}\text { Valor Total } \\
\text { do Projeto } \\
\text { (R\$) }\end{array}$ & $\begin{array}{c}\text { Populaçã } \\
\text { O Censo } \\
2010 \\
\end{array}$ \\
\hline 50 & 2001 & $\begin{array}{l}\text { CR01262381 } \\
1 / 01 \\
\end{array}$ & Gestão Integrada de Resíduos Sólidos & $\begin{array}{l}\text { Prefeitura Municipal de } \\
\text { Estrela }\end{array}$ & $\begin{array}{l}\text { Ampliação da infraestrutura da UTL } \\
\text { Estrela e implantação do plano de } \\
\text { gerenciamento integrado de resíduos } \\
\text { sólidos visando a implementação da } \\
\text { coleta seletiva com valorização dos } \\
\text { catadores }\end{array}$ & RS & Municipal & 548.240 & 152.419 & 700.659 & 30.619 \\
\hline 51 & 2001 & $\begin{array}{l}\text { CR01262392 } \\
5 / 01\end{array}$ & Gestão Integrada de Resíduos Sólidos & $\begin{array}{l}\text { Prefeitura Municipal de } \\
\text { Osório }\end{array}$ & $\begin{array}{l}\text { Elaboração do plano integrado de } \\
\text { resíduos sólidos, projeto executivo de } \\
\text { aterro sanitário, implantação de } \\
\text { aterro sanitário e recuperação da } \\
\text { área degradada para cidade de } \\
\text { Osório. }\end{array}$ & RS & Municipal & 425.168 & 173.520 & 598.688 & 40.906 \\
\hline 52 & 2001 & \begin{tabular}{|l} 
CR01262859 \\
7/01 \\
\end{tabular} & Gestão Integrada de Resíduos Sólidos & $\begin{array}{l}\text { Prefeitura Municipal de } \\
\text { Quaraí }\end{array}$ & $\begin{array}{l}\text { Implantaç̃o coleta seletiva, unidade } \\
\text { de triagem e unidade de } \\
\text { compostagem para disposicão final } \\
\text { adequada de resíduos sólidos } \\
\text { domésticos em Quaraí. }\end{array}$ & RS & Municipal & 242.062 & 12.740 & 254.802 & 23.021 \\
\hline 53 & 2001 & $\begin{array}{l}\text { CR01281340 } \\
\text { 0/01 } \\
\end{array}$ & Gestão Integrada de Resíduos Sólidos & $\begin{array}{l}\text { Prefeitura Municipal de } \\
\text { Salgueiro }\end{array}$ & Salgueiro, mais limpo e mais belo. & $\mathrm{PE}$ & Municipal & 395.468 & 46.078 & 441.546 & 56.629 \\
\hline 54 & 2001 & $\begin{array}{l}\text { CR01281351 } \\
5 / 01\end{array}$ & Gestão Integrada de Resíduos Sólidos & $\begin{array}{l}\text { Prefeitura Municipal de } \\
\text { Lajedo }\end{array}$ & Lajedo, cidade limpa. & PE & Municipal & 395.468 & 45.078 & 440.546 & 36.628 \\
\hline 55 & 2001 & $\begin{array}{l}\text { CR01281373 } \\
\text { 3/01 } \\
\end{array}$ & Gestão Integrada de Resíduos Sólidos & $\begin{array}{l}\text { Prefeitura Municipal de } \\
\text { Cerquilho }\end{array}$ & $\begin{array}{l}\text { Plano de Gerenciamento Integrado } \\
\text { dos Resíduos Sólidos; projeto } \\
\text { executivo e implantação do aterro } \\
\text { sanitário a a recuperação de lixão de } \\
\text { Cerquilho. }\end{array}$ & SP & Municipal & 427.573 & 157.488 & 585.061 & 39.617 \\
\hline 56 & 2001 & $\begin{array}{l}\text { CR01284081 } \\
4 / 01 \\
\end{array}$ & Gestão Integrada de Resíduos Sólidos & Prefeitura Municipal de Lavras & \begin{tabular}{|l} 
Elaboração do Plano de \\
Gerenciamento Integrado dos \\
Resíduos Sólidos urbanos do \\
município de lavras/implantação do \\
aterro sanitário municipal
\end{tabular} & MG & Municipal & 443.049 & 201.520 & 644.569 & 92.200 \\
\hline 57 & 2001 & $\begin{array}{l}\text { CR01284092 } \\
8 / 01 \\
\end{array}$ & Gestão Integrada de Resíduos Sólidos & $\begin{array}{l}\text { Prefeitura Municipal de } \\
\text { Mariana }\end{array}$ & $\begin{array}{l}\text { Plano de Gerenciamento Integrado } \\
\text { dos Resíduos Sólidos }\end{array}$ & MG & Municipal & 414.396 & 103.783 & 518.179 & 54.219 \\
\hline
\end{tabular}




\begin{tabular}{|c|c|c|c|c|c|c|c|c|c|c|c|}
\hline & Ano & $\mathrm{n} \mathrm{CV}$ & Tema & Instituição Convenente & Título do Projeto & UF & $\begin{array}{c}\text { Esfera } \\
\text { Institucional }\end{array}$ & $\begin{array}{l}\text { Recurso do } \\
\text { FNMA (R\$̦) }\end{array}$ & $\begin{array}{c}\text { Recursos de } \\
\text { Contra } \\
\text { Partida (R\$) }\end{array}$ & $\begin{array}{l}\text { Valor Total } \\
\text { do Projeto } \\
\text { (R\$) }\end{array}$ & $\begin{array}{l}\text { População } \\
\text { Censo } 2010\end{array}$ \\
\hline 58 & 2001 & \begin{tabular}{|l|} 
CR01284110 \\
$57 / 01$ \\
\end{tabular} & Gestão Integrada de Resíduos Sólidos & $\begin{array}{l}\text { Prefeitura Municipal de } \\
\text { Aquiraz }\end{array}$ & $\begin{array}{l}\text { Gerenciamento Integrado dos } \\
\text { Resíduos Sólidos }\end{array}$ & $\mathrm{CE}$ & Municipal & 140.045 & 16.190 & 156.235 & 72.628 \\
\hline 59 & 2001 & \begin{tabular}{|l|} 
CR01284116 \\
$1 / 01$ \\
\end{tabular} & Gestão Integrada de áreas protegidas & $\begin{array}{l}\text { Prefeitura Municipal de são } \\
\text { Manuel }\end{array}$ & $\begin{array}{l}\text { Plano de gerenciamento integrado de } \\
\text { resíduos sólidos de são Miguel/SP } \\
\text { implantação de aterro sanitário; } \\
\text { recuperação do lixão e apoio aos } \\
\text { trabalhadores em coleta seletiva e } \\
\text { reciclagem de resíduos sólidos. }\end{array}$ & SP & Municipal & 390.297 & 174.541 & 564.838 & 38.342 \\
\hline 60 & 2001 & \begin{tabular}{|l|} 
CR01284127 \\
5/01 \\
\end{tabular} & Gestão Integrada de Resíduos Sólidos & $\begin{array}{l}\text { Prefeitura Municipal de } \\
\text { Agrestina }\end{array}$ & Compromisso com o meio ambiente & $\mathrm{PE}$ & Municipal & 401.668 & 48.078 & 449.746 & 22.679 \\
\hline 61 & 2001 & \begin{tabular}{|l|} 
CR01284138 \\
9/01 \\
\end{tabular} & Gestão Integrada de Resíduos Sólidos & $\begin{array}{l}\text { Prefeitura Municipal de nova } \\
\text { lima }\end{array}$ & $\begin{array}{l}\text { Plano de gestão integrada de resíduos } \\
\text { sólidos }\end{array}$ & MG & Municipal & 448.429 & 547.121 & 995.550 & 80.998 \\
\hline 62 & 2001 & \begin{tabular}{|l|} 
CR01284149 \\
$3 / 01$ \\
\end{tabular} & Gestão Integrada de Resíduos Sólidos & $\begin{array}{l}\text { Prefeitura Municipal de } \\
\text { Araguari }\end{array}$ & $\begin{array}{l}\text { Gestão de resíduos sólidos urbanos } \\
\text { do município de Araguari }\end{array}$ & MG & Municipal & 448.982 & 178.895 & 627.877 & 109.801 \\
\hline 63 & 2001 & \begin{tabular}{|l|} 
CR01284150 \\
$7 / 01$ \\
\end{tabular} & Gestão Integrada de Resíduos Sólidos & Prefeitura Municipal de arcos & Implantação do PGIRS - Arcos/MG & MG & Municipal & 449.471 & 401.710 & 851.181 & 36.597 \\
\hline 64 & 2001 & \begin{tabular}{|l|} 
CR01292797 \\
$3 / 01$ \\
\end{tabular} & Gestão Integrada de Resíduos Sólidos & $\begin{array}{l}\text { Prefeitura Municipal de } \\
\text { palmas }\end{array}$ & $\begin{array}{l}\text { Gestão integrada de resíduos sólidos } \\
\text { urbanos }\end{array}$ & $\mathrm{PR}$ & Municipal & 373.336 & 75.000 & 448.336 & 42.888 \\
\hline 65 & 2001 & \begin{tabular}{|l|} 
CR01292811 \\
$4 / 01$
\end{tabular} & Gestão Integrada de Resíduos Sólidos & $\begin{array}{l}\text { Prefeitura Municipal de } \\
\text { Quirinópolis }\end{array}$ & $\begin{array}{l}\text { Diretrizes para o equacionamento da } \\
\text { problemática dos resíduos sólidos } \\
\text { urbanos gerados no município de } \\
\text { Quirinópolis- GO }\end{array}$ & GO & Municipal & 358.558 & 284.690 & 643.248 & 43.220 \\
\hline 66 & 2001 & \begin{tabular}{|l|} 
CR01295905 \\
9/01 \\
\end{tabular} & Gestão Integrada de Resíduos Sólidos & $\begin{array}{l}\text { Prefeitura Municipal de Paulo } \\
\text { Afonso }\end{array}$ & $\begin{array}{l}\text { Gerenciamento Integrado dos } \\
\text { Resíduos Sólidos }\end{array}$ & BA & Municipal & 393.031 & 58.100 & 451.131 & 108.396 \\
\hline 67 & 2001 & \begin{tabular}{|l|} 
CR01295916 \\
$3 / 01$
\end{tabular} & Gestão Integrada de Resíduos Sólidos & $\begin{array}{l}\text { Prefeitura Municipal de } \\
\text { curitibanos }\end{array}$ & $\begin{array}{l}\text { Gestão de resíduos sólidos para } \\
\text { curitibanos }\end{array}$ & SC & Municipal & 289.375 & 137.308 & 426.683 & 37.748 \\
\hline 68 & 2001 & Cv053/01 & Gestão Integrada de Resíduos Sólidos & $\begin{array}{l}\text { Prefeitura municipal de } \\
\text { limoeiro do norte }\end{array}$ & $\begin{array}{l}\text { Tratamento dos resíduos sólidos da } \\
\text { cidade de limoeiro do norte }\end{array}$ & $\mathrm{CE}$ & Municipal & 279.963 & 365.835 & 645.798 & 56.264 \\
\hline 69 & 2001 & Cv058/01 & Gestão Integrada de Resíduos Sólidos & $\begin{array}{l}\text { Prefeitura municipal de } \\
\text { bonito }\end{array}$ & Bonito, naturalmente limpo. & $\mathrm{PE}$ & Municipal & 254.130 & 33.718 & 287.848 & 37.566 \\
\hline 70 & 2002 & CR/CAIXA & Qualidade ambiental & Prefeitura municipal de Salto & $\begin{array}{l}\text { Projeto lixo separado - cidade limpa - } \\
\text { implantação coleta } \\
\text { seletiva/melhoramento ampliação do } \\
\text { aterro }\end{array}$ & SP & Municipal & 500.000 & $261.230,16$ & $761.230,16$ & 105.516 \\
\hline
\end{tabular}




\begin{tabular}{|c|c|c|c|c|c|c|c|c|c|c|c|}
\hline & Ano & $\mathrm{n} \mathrm{CV}$ & Tema & Instituição Convenente & Título do Projeto & UF & $\begin{array}{c}\text { Esfera } \\
\text { Institucional }\end{array}$ & $\begin{array}{l}\text { Recurso do } \\
\text { FNMA (R\$) }\end{array}$ & $\begin{array}{c}\text { Recursos de } \\
\text { Contra } \\
\text { Partida (R\$) }\end{array}$ & $\begin{array}{l}\text { Valor Total } \\
\text { do Projeto } \\
\text { (R\$) }\end{array}$ & $\begin{array}{l}\text { População } \\
\text { Censo 2010 }\end{array}$ \\
\hline 71 & 2002 & CR/CAIXA & Qualidade ambiental & $\begin{array}{l}\text { Prefeitura municipal de Lagoa } \\
\text { Vermelha }\end{array}$ & $\begin{array}{l}\text { Fomento a projetos de gestão } \\
\text { integrada de resíduos sólidos }\end{array}$ & RS & Municipal & 410.889 & $230.127,05$ & $641.016,05$ & 27.525 \\
\hline 72 & 2002 & CR/CAIXA & Qualidade ambiental & $\begin{array}{l}\text { Prefeitura municipal de } \\
\text { Toritama }\end{array}$ & $\begin{array}{l}\text { Implantação do aterro sanitário, } \\
\text { projeto recuperação do lixão. }\end{array}$ & $\mathrm{PE}$ & Municipal & 399.668 & 49.578 & 449.246 & 35.554 \\
\hline 73 & 2002 & CR/CAIXA & Qualidade ambiental & $\begin{array}{l}\text { Prefeitura municipal de lagoa } \\
\text { da Prata }\end{array}$ & $\begin{array}{l}\text { Implantação do aterro sanitário e } \\
\text { plano social }\end{array}$ & MG & Municipal & 450.000 & 200.711 & 650.711 & 45.984 \\
\hline 74 & 2002 & CR/CAIXA & Qualidade ambiental & Prefeitura municipal de Juína & $\begin{array}{l}\text { Projeto de gestão integrada de } \\
\text { resíduos sólidos }\end{array}$ & MT & Municipal & 449.262 & 90.000 & 539.262 & 39.255 \\
\hline 75 & 2002 & CR/CAIXA & Qualidade ambiental & $\begin{array}{l}\text { Prefeitura municipal de } \\
\text { Maués }\end{array}$ & $\begin{array}{l}\text { Disponibilizar recursos para o } \\
\text { desenvolvimento de projetos que } \\
\text { busquem a destinação final } \\
\text { ambientalmente adequada }\end{array}$ & AM & Municipal & 448.580 & 145.800 & 594.380 & 52.236 \\
\hline 76 & 2002 & CR/CAIXA & Qualidade ambiental & $\begin{array}{l}\text { Prefeitura municipal de } \\
\text { Trindade do Sul }\end{array}$ & Gestão integrada de resíduos sólidos & RS & Municipal & 388.573 & $311.222,06$ & $699.795,06$ & 5.787 \\
\hline 77 & 2002 & CR/CAIXA & Qualidade ambiental & $\begin{array}{l}\text { Prefeitura municipal de } \\
\text { Paracatu }\end{array}$ & $\begin{array}{l}\text { Gerenciamento Integrado de resíduos } \\
\text { sólidos urbanos de Paracatu/MG }\end{array}$ & MG & Municipal & $549.977,00$ & $211.921,57$ & $761.898,57$ & 84.718 \\
\hline 78 & 2002 & CR/CAIXA & Qualidade ambiental & $\begin{array}{l}\text { Prefeitura municipal de Dois } \\
\text { Irmãos }\end{array}$ & Gestão de resíduos sólidos & RS & Municipal & $340.777,00$ & $101.464,86$ & $442.241,86$ & 27.572 \\
\hline 79 & 2002 & CR/CAIXA & Qualidade ambiental & $\begin{array}{l}\text { Prefeitura municipal de } \\
\text { Lençóis Paulista }\end{array}$ & $\begin{array}{l}\text { Implantação da coleta seletiva e } \\
\text { triagem }\end{array}$ & SP & Municipal & $467.428,00$ & $220.251,42$ & $687.679,42$ & 61.428 \\
\hline 80 & 2002 & CR/CAIXA & Qualidade ambiental & $\begin{array}{l}\text { Prefeitura municipal de } \\
\text { Itumbiara }\end{array}$ & $\begin{array}{l}\text { Aquisição balança prensa hidráulica, } \\
\text { urbanização, trincheiras, galpão, } \\
\text { elaboração PGIRS, estudos de } \\
\text { recuperação do lixão. }\end{array}$ & $\mathrm{GO}$ & Municipal & 411.112 & 317.199 & 728.311 & 92.883 \\
\hline 81 & 2002 & CR/CAIXA & Qualidade ambiental & $\begin{array}{l}\text { Prefeitura municipal de } \\
\text { Maragogipe }\end{array}$ & $\begin{array}{l}\text { Instalação de usina de lixo e } \\
\text { implantação coleta seletiva }\end{array}$ & BA & Municipal & 384.000 & 166.719 & $550.719^{41}$ & 42.815 \\
\hline 82 & 2002 & CR/CAIXA & Qualidade ambiental & $\begin{array}{l}\text { Prefeitura municipal de } \\
\text { Campo Mourão }\end{array}$ & Ampliação da coleta seletiva de lixo & PR & Municipal & 160.707 & 238.184 & 398.891 & 87.194 \\
\hline 83 & 2002 & CR/CAIXA & Qualidade ambiental & $\begin{array}{l}\text { Prefeitura municipal de Porto } \\
\text { Nacional }\end{array}$ & $\begin{array}{l}\text { Implantação do aterro sanitário e } \\
\text { programa de Educação ambiental }\end{array}$ & то & Municipal & 407.908 & 114.659 & 522.567 & 49.146 \\
\hline
\end{tabular}

${ }^{41} \mathrm{O}$ valor total do projeto no documento original é de R $\$ 550,179.00$ (FNMA, 2014b). No entanto, a soma dos recursos do FNMA mais os recursos de Contra Partida totalizam $\mathrm{R} \$ 550,719.00, \log \mathrm{o}$ o valor foi corrigido no presente relatório. 


\begin{tabular}{|c|c|c|c|c|c|c|c|c|c|c|c|}
\hline & Ano & n CV & Tema & Instituição Convenente & Título do Projeto & UF & $\begin{array}{c}\text { Esfera } \\
\text { Institucional }\end{array}$ & $\begin{array}{l}\text { Recurso do } \\
\text { FNMA (R\$) }\end{array}$ & $\begin{array}{l}\text { Recursos de } \\
\text { Contra } \\
\text { Partida (R\$) }\end{array}$ & $\begin{array}{l}\text { Valor Total } \\
\text { do Projeto } \\
\text { (R\$) }\end{array}$ & $\begin{array}{l}\text { População } \\
\text { Censo } 2010 \\
\end{array}$ \\
\hline 84 & 2002 & CR/CAIXA & Qualidade ambiental & $\begin{array}{l}\text { Prefeitura municipal de } \\
\text { Mirassol }\end{array}$ & $\begin{array}{l}\text { Melhorias no sistema de limpeza } \\
\text { publica e PIGRS de Mirassol }\end{array}$ & SP & Municipal & 325.366 & 479.196 & 804.562 & 53.792 \\
\hline 85 & 2002 & CR/CAIXA & Qualidade ambiental & $\begin{array}{l}\text { Prefeitura municipal de } \\
\text { Ibirama }\end{array}$ & $\begin{array}{l}\text { Gestão e execução participativa, } \\
\text { elaboração PGIRS, implantação de } \\
\text { aterro sanitário, recuperação dos } \\
\text { lixões e plano social. }\end{array}$ & SC & Municipal & $444.872,00$ & $357.008,47$ & $801.880,47$ & 17.330 \\
\hline 86 & 2002 & CR/CAIXA & Qualidade ambiental & $\begin{array}{l}\text { Prefeitura municipal de } \\
\text { Xinguara }\end{array}$ & $\begin{array}{l}\text { Elaboração do projeto executivo de } \\
\text { aterro sanitário, plano social, } \\
\text { recuperação do lixão. }\end{array}$ & PA & Municipal & 266.615 & 88.340 & 354.955 & 40.573 \\
\hline 87 & 2002 & CR/CAIXA & Qualidade ambiental & $\begin{array}{l}\text { Prefeitura municipal de } \\
\text { Palmares }\end{array}$ & Elaboração do PGIRS & $\mathrm{PE}$ & Municipal & 402.668 & 47.078 & 449.746 & 59.526 \\
\hline 88 & 2005 & CR/CAIXA & Qualidade ambiental & $\begin{array}{l}\text { Prefeitura municipal de } \\
\text { Janaúba }\end{array}$ & $\begin{array}{l}\text { Gestão integrada de resíduos sólidos } \\
\text { no município de Janaúba/MG }\end{array}$ & MG & Municipal & $599.935,00$ & $665.738,86$ & $1.265 .673,86$ & 66.803 \\
\hline 89 & 2006 & CV027/06 & Qualidade ambiental & $\begin{array}{l}\text { Prefeitura municipal de } \\
\text { Formiga }\end{array}$ & $\begin{array}{l}\text { Resíduos sólidos } \mathrm{x} \text { meio ambiente } \\
\text { buscando o equilíbrio }\end{array}$ & MG & Municipal & 597.679 & 152.800 & 750.479 & 65.128 \\
\hline 90 & 2006 & CV033/06 & Qualidade ambiental & $\begin{array}{l}\text { Prefeitura municipal de } \\
\text { Porteirinha }\end{array}$ & $\begin{array}{l}\text { Plano de gestão integrada de resíduos } \\
\text { sólidos - PGIRS de Porteirinha - MG }\end{array}$ & MG & Municipal & 387.790 & 38.779 & 426.569 & 37.627 \\
\hline 91 & 2006 & CV035/06 & Qualidade ambiental & $\begin{array}{l}\text { Prefeitura municipal de Lagoa } \\
\text { Santa }\end{array}$ & $\begin{array}{l}\text { Plano de gestão integrada de resíduos } \\
\text { sólidos urbanos de lagoa Santa }\end{array}$ & MG & Municipal & 597.265 & 149.317 & 746.582 & 52.520 \\
\hline 92 & 2006 & CV044/06 & Qualidade ambiental & $\begin{array}{l}\text { Prefeitura municipal de } \\
\text { Correntina }\end{array}$ & $\begin{array}{l}\text { Gestão de resíduos sólidos e } \\
\text { implantação de aterro sanitário de } \\
\text { Correntina }\end{array}$ & BA & Municipal & 502.375 & 55.900 & 558.275 & 31.249 \\
\hline 93 & 2006 & CV109/06 & Qualidade ambiental & $\begin{array}{l}\text { Prefeitura municipal de } \\
\text { Pirapora }\end{array}$ & $\begin{array}{l}\text { Plano de gestão integrada de resíduos } \\
\text { sólidos urbanos de Pirapora }\end{array}$ & MG & Municipal & 559.650 & 128.740 & 688.390 & 53.368 \\
\hline 94 & 2007 & Cv013/07 & Qualidade ambiental & Prefeitura Municipal de Barra & $\begin{array}{l}\text { Elaboração de plano integrado de } \\
\text { gestão de resíduos sólidos, projeto } \\
\text { executivo e implantação de aterro } \\
\text { sanitário e recuperação de lixão na } \\
\text { cidade de Barra. }\end{array}$ & BA & Municipal & 425.070 & 35.300 & 460.370 & 49.325 \\
\hline 95 & 2007 & Cv031/07 & Qualidade ambiental & $\begin{array}{l}\text { Prefeitura Municipal de } \\
\text { Bocaiúva }\end{array}$ & $\begin{array}{l}\text { Gestão integrada de resíduos sólidos } \\
\text { no município de Bocaiúva }\end{array}$ & MG & Municipal & 566.732 & 31.500 & 598.232 & 46.654 \\
\hline 96 & 2012 & CV10/2012 & Sociedade sustentáveis & $\begin{array}{l}\text { Município de Santa Cruz do } \\
\text { Sul }\end{array}$ & $\begin{array}{l}\text { Ações educativas para a gestão de } \\
\text { resíduos sólidos urbanos no } \\
\text { município de Santa Cruz do Sul }\end{array}$ & RS & Municipal & $270.689,90$ & $23.713,23$ & $294.403,13$ & 118.374 \\
\hline
\end{tabular}




\begin{tabular}{|c|c|c|c|c|c|c|c|c|c|c|c|}
\hline & Ano & $\mathrm{nCV}$ & Tema & Instituição Convenente & Título do Projeto & UF & $\begin{array}{c}\text { Esfera } \\
\text { Institucional }\end{array}$ & $\begin{array}{l}\text { Recurso do } \\
\text { FNMA (R\$) }\end{array}$ & $\begin{array}{c}\text { Recursos de } \\
\text { Contra } \\
\text { Partida (R\$) }\end{array}$ & $\begin{array}{l}\text { Valor Total } \\
\text { do Projeto } \\
\text { (R\$) }\end{array}$ & $\begin{array}{l}\text { População } \\
\text { Censo 2010 } \\
\end{array}$ \\
\hline 97 & 2012 & CV13/2012 & Sociedade sustentáveis & Município de Lajeado & $\begin{array}{l}\text { Ações educativas para a gestão de } \\
\text { resíduos sólidos }\end{array}$ & RS & Municipal & $236.887,90$ & 31.353 & $268.240,90$ & 71.445 \\
\hline 98 & 2012 & CV17/2012 & Sociedade sustentáveis & $\begin{array}{l}\text { Município de Luís Eduardo } \\
\text { Magalhães }\end{array}$ & $\begin{array}{l}\text { Ações educativas para a gestão de } \\
\text { resíduos sólidos }\end{array}$ & $\mathrm{BA}$ & Municipal & $219.621,83$ & 14.654 & $234.275,83$ & 60.105 \\
\hline 99 & 2012 & CV18/2012 & Sociedade sustentáveis & Município de Votuporanga & $\begin{array}{l}\text { Ações educativas para a gestão de } \\
\text { resíduos sólidos }\end{array}$ & SP & Municipal & 200000,00 & 39507,33 & $239.507,33$ & 84.692 \\
\hline $\begin{array}{r}10 \\
0 \\
\end{array}$ & 2012 & CV19/2012 & Sociedade sustentáveis & Município de Campo grande & $\begin{array}{l}\text { Ações educativas para a gestão de } \\
\text { resíduos sólidos }\end{array}$ & MS & Municipal & $265.907,25$ & 22.501 & $288.408,25$ & 786.797 \\
\hline & & & & & & & Total Recursos & $34.602 .155,44$ & $\begin{array}{r}\text { 13.765.663, } \\
37\end{array}$ & $\begin{array}{r}48.367 .818 \\
81\end{array}$ & $\begin{array}{l}6.418 .173 \\
00\end{array}$ \\
\hline
\end{tabular}

Relação dos convênios realizados pelo FNMA entre 1990-2012 nas categorias de gestão integrada de resíduos sólidos e qualidade ambiental na esfera municipal relacionados à Consórcios Públicos ${ }^{42}$

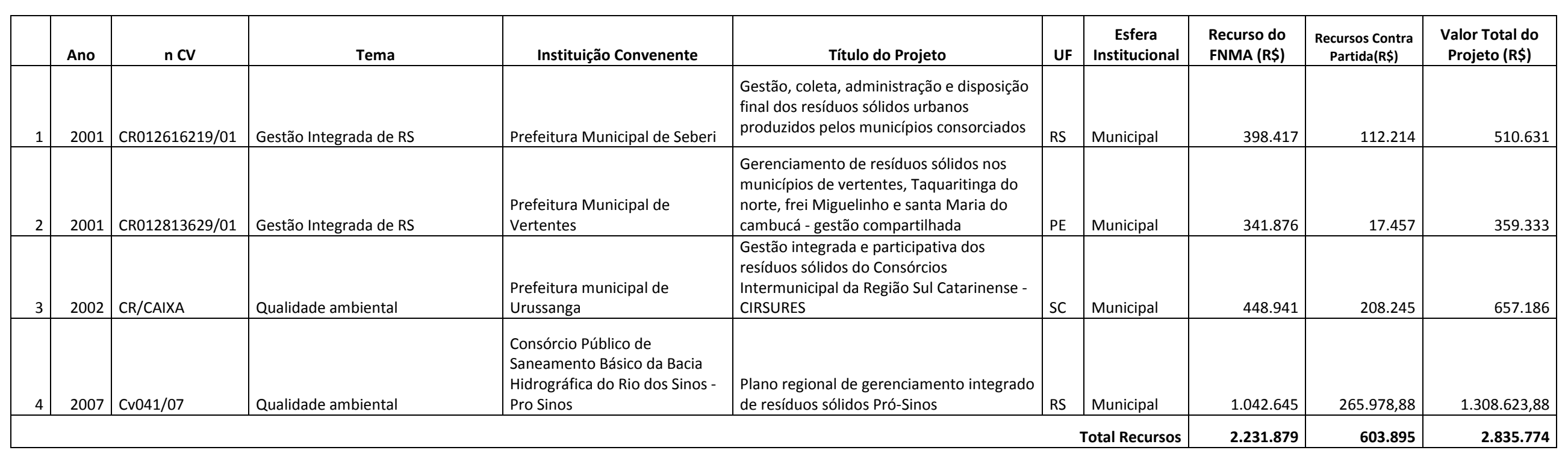

${ }^{42}$ Não foi possível relacionar a população de cada convênio para Consórcios Públicos, por não estar especificado os municípios integrantes do respectivo Consórcio. 


\section{APÊNDICE C - Questionário enviado aos Consórcios Públicos para GRSU no Brasil}

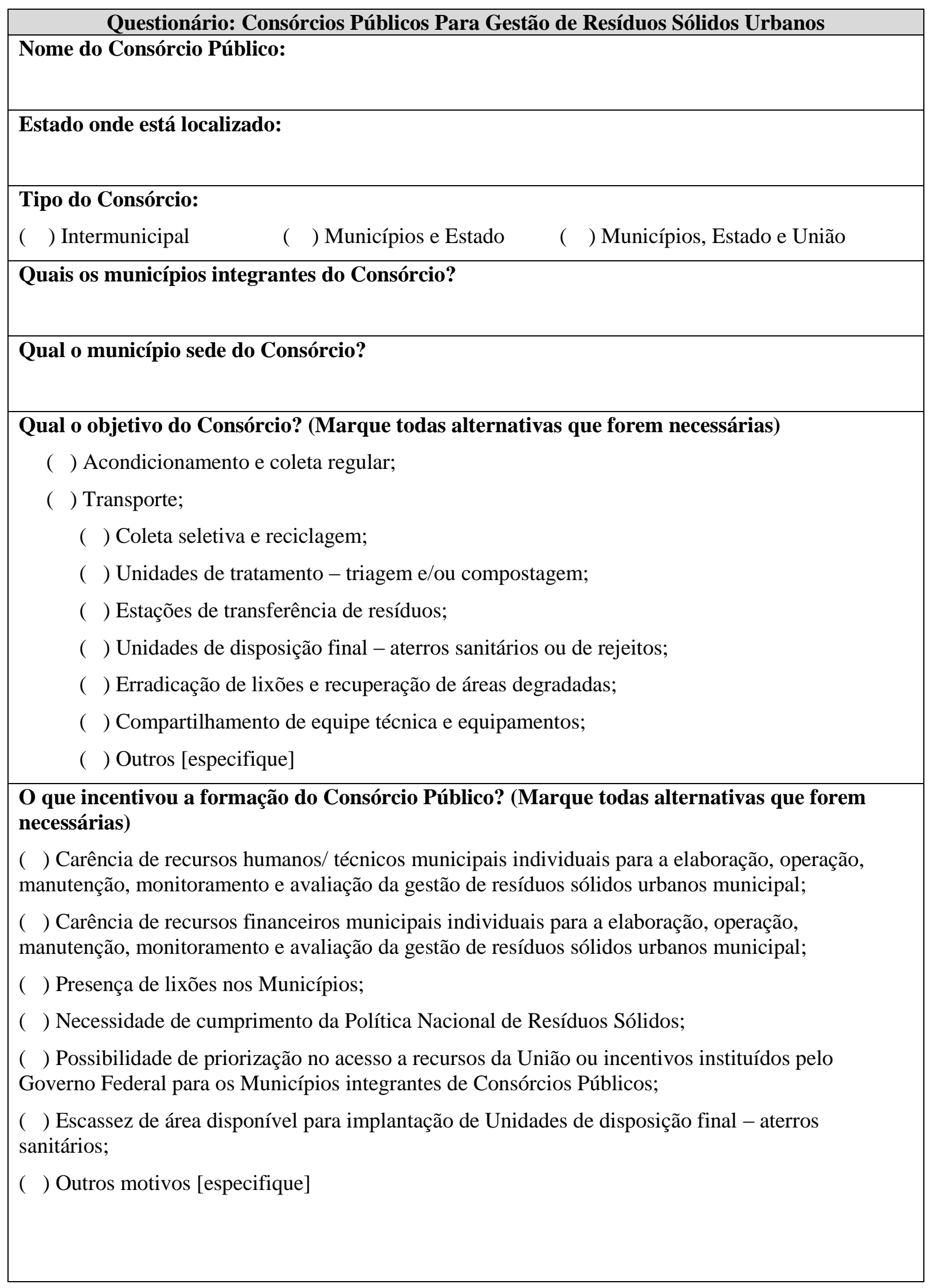




\section{Em relação ao Plano de Gestão Integrada de Resíduos Sólidos, assinale os Planos existentes (marque todas as alternativas que forem necessárias):}

( ) Plano Estadual de Gestão Integrada de Resíduos Sólidos (PEGIRS)

( ) Plano Municipal de Gestão Integrada de Resíduos Sólidos (PMGIRS)

( ) Plano Intermunicipal de Gestão Integrada de Resíduos Sólidos (do Consórcio)

Quais atividades o Consórcio realizou? (Marque todas alternativas que forem necessárias)

\begin{tabular}{|c|c|}
\hline Etapas & \\
\hline $\begin{array}{l}\text { Realização de estudo de viabilidade econômico-financeira do } \\
\text { Consórcio }\end{array}$ & $($ ) \\
\hline Realização de estudos de impactos ambientais e sociais & $($ ) \\
\hline $\begin{array}{l}\text { Realização de estudos territoriais, ocupação do uso do solo e distância } \\
\text { entre os municípios. }\end{array}$ & ( ) \\
\hline $\begin{array}{l}\text { Captação de informações sobre a geração de resíduos sólidos urbanos } \\
\text { de cada município (quantidade e composição) }\end{array}$ & ( ) \\
\hline $\begin{array}{l}\text { Consulta e envolvimento das partes interessadas: Órgão de limpeza } \\
\text { municipal; ONGs do setor de resíduos sólidos; Comunidades vizinhas } \\
\text { aos aterros sanitários; População do município sede; Empresas do } \\
\text { setor; Cooperativas de catadores de materiais recicláveis. }\end{array}$ & $($ ) \\
\hline $\begin{array}{l}\text { Consultas e envolvimento de Secretarias Estaduais e/ou Municipais: } \\
\text { Cidades, Meio Ambiente, Planejamento Urbano, Saúde, Saneamento e } \\
\text { Câmaras Municipais. }\end{array}$ & $($ ) \\
\hline Elaboração e assinatura do Protocolo de Intenções do Consórcio & ( ) \\
\hline Ratificação do Protocolo de Intenções & $($ ) \\
\hline Convocação da Assembleia Geral & $($ ) \\
\hline $\begin{array}{l}\text { Aprovação do Estatuto pela Assembleia Geral e publicação na } \\
\text { Imprensa Oficial }\end{array}$ & $($ ) \\
\hline Início das atividades do Consórcio & $($ ( ) \\
\hline Operação do Consórcio & ( ) \\
\hline Outra etapa [informe] & \\
\hline
\end{tabular}

\section{Qual o ano que ocorreu?}

Elaboração e assinatura do Protocolo de Intenções do Consórcio:

Ratificação do Protocolo de Intenções:

Início das atividades do Consórcio:

Operação do Consórcio:

Qual papel estadual na formação e manutenção do Consórcio?

\begin{tabular}{|l|l|}
\hline ( ) & Nenhum (pule para o item 12) \\
\hline ( ) & O estado é integrante do Consórcio \\
\hline ( ) & Apoio de recursos financeiros \\
\hline
\end{tabular}




\begin{tabular}{|l|l|l|}
\hline$(~)$ & Apoio de recursos técnicos ou capacitação \\
\hline$($ ) & Apoio institucional e jurídico \\
\hline$($ ) & Regulação \\
\hline$(~)$ & Fiscalização \\
\hline$($ ) & Outros [ informe] \\
\hline
\end{tabular}

Em relação a execução adotada para a prestação dos serviços de resíduos sólidos urbanos, correlacione as atividades executadas com os entes responsáveis pela execução: (marque todas alternativas que forem necessárias):

\begin{tabular}{|c|c|c|c|c|c|c|}
\hline & $\begin{array}{l}\text { Coleta } \\
\text { regular }\end{array}$ & $\begin{array}{l}\text { Coleta } \\
\text { seletiva }\end{array}$ & Transporte & $\begin{array}{l}\text { Galpão de } \\
\text { triagem - } \\
\text { reciclagem }\end{array}$ & $\begin{array}{l}\text { Estação de } \\
\text { Transferência } \\
\text { de resíduos }\end{array}$ & $\begin{array}{c}\text { Disposição final } \\
\text { - aterro } \\
\text { sanitário }\end{array}$ \\
\hline $\begin{array}{l}\text { Prefeitura ou } \\
\text { Departamento } \\
\text { Limpeza Urbana }\end{array}$ & ( ) & ( ) & ( ) & ( ) & ( ) & ( ) \\
\hline $\begin{array}{l}\text { Consórcio } \\
\text { (diretamente) / } \\
\text { Consórcio Público } \\
\text { Contrato de } \\
\text { Programa }\end{array}$ & $($ ) & ( ) & $($ ) & $($ ) & $($ ) & $($ ) \\
\hline $\begin{array}{l}\text { Consórcio } \\
\text { (indiretamente) / } \\
\text { Consórcio Público } \\
\text { - Concessão }\end{array}$ & ( ) & ( ) & ( ) & $($ ) & $($ ) & ( ) \\
\hline $\begin{array}{l}\text { Consórcio } \\
\text { (indiretamente) / } \\
\text { Consórcio Público } \\
\text { - Parceira Público } \\
\text { Privada (PPP) }\end{array}$ & $($ ( ) & ( ) & $($ ) & $($ ( ) & $($ ( ) & ( ) \\
\hline
\end{tabular}

- Se a forma de execução do Consórcio não estiver listada acima, por favor informe:

\section{O Consórcio contou ou conta com outros recursos que NÃO sejam apenas aqueles} disponibilizados pelos Municípios integrantes do consórcio - contrato de rateio?

Caso sua resposta seja não, pule para o item 15.

Caso sua resposta seja sim, selecione as fontes e os valores de financiamento (marque todas as alternativas necessárias).

\begin{tabular}{|c|c|c|c|c|c|}
\hline ( ) & $\begin{array}{l}\text { Programas do Governo } \\
\text { Federal }\end{array}$ & $\begin{array}{l}\text { Até R\$ } \\
50.000\end{array}$ & $\begin{array}{l}\text { De } R \$ 51.000 a \\
R \$ 300.000\end{array}$ & $\begin{array}{l}\text { De } \mathrm{R} \$ 301.000 \text { a } \mathrm{R} \$ \\
1.000 .000\end{array}$ & $\begin{array}{l}\text { Acima de } \mathrm{R} \$ \\
1.000 .000\end{array}$ \\
\hline ( ) & $\begin{array}{l}\text { Fundação Nacional de } \\
\text { Saúde - FUNASA }\end{array}$ & ( ) & $(\quad)$ & ( ) & $(\quad)$ \\
\hline ( ) & $\begin{array}{l}\text { Fundo Nacional do Meio } \\
\text { Ambiente - FNMA }\end{array}$ & $(\quad)$ & $($ ) & $($ ) & $($ ) \\
\hline ( ) & $\begin{array}{l}\text { Organismos } \\
\text { Internacionais }\end{array}$ & $($ ) & $(\quad)$ & $(\quad)$ & $(\quad)$ \\
\hline ( ) & Fundos Estaduais & $(\quad)$ & $(\quad)$ & $(\quad)$ & $($ ) \\
\hline
\end{tabular}




\begin{tabular}{|c|c|c|c|c|c|}
\hline$($ ( ) & Fundos Municipais & ( ) & ( ) & ( ) & $($ ( ) \\
\hline ( ) & Investimentos privados & ( ) & ( ) & $($ ) & ( ) \\
\hline ( ) & Outros & ( ) & ( ) & $(\quad)$ & ( ) \\
\hline
\end{tabular}

Os recursos do(s) financiamento(s) relatado(s) no item 13 foram usados com qual finalidade? (marque todas alternativas que forem necessárias):

\begin{tabular}{|l|l|}
\hline & \multicolumn{1}{|c|}{ Finalidade } \\
\hline ( ) & Elaboração do Plano Intermunicipal de Resíduos Sólidos \\
\hline ( ) & $\begin{array}{l}\text { Elaboração de estudos: viabilidade econômico-financeira do } \\
\text { Consórcio; impactos ambientais e sociais; territoriais, ocupação do } \\
\text { uso do solo e distância entre os municípios; de informações sobre a } \\
\text { geração de resíduos sólidos urbanos de cada município (quantidade e } \\
\text { composição). }\end{array}$ \\
\hline ( ) & Coleta e Transporte: veículos e equipamentos. \\
\hline ( ) & $\begin{array}{l}\text { Destinação (Infraestrutura de estações de transferência; Galpão de } \\
\text { triagem para recuperação de recicláveis; Pátio de compostagem; } \\
\text { Equipamentos). }\end{array}$ \\
\hline ( ) & $\begin{array}{l}\text { Disposição Final - aterro sanitário: (Construção - infraestrutura para } \\
\text { implantação; Operação - equipamentos; Manutenção). }\end{array}$ \\
\hline ( ) & Outra finalidade [especifique]: -- \\
\hline
\end{tabular}

No planejamento do Consórcio, informe a fonte de recursos prevista para a manutenção dos serviços (marque todas alternativas que forem necessárias):

\begin{tabular}{|c|c|c|c|c|c|}
\hline & Prefeitura & $\begin{array}{l}\text { Contrato } \\
\text { de Rateio }\end{array}$ & $\begin{array}{c}\text { Cobrança } \\
\text { de taxa }\end{array}$ & $\begin{array}{c}\text { ICMS } \\
\text { Ecológico }\end{array}$ & $\begin{array}{c}\text { Subsídio Estadual } \\
\text { ou da União }\end{array}$ \\
\hline $\begin{array}{l}\text { Varrição e limpeza } \\
\text { pública }\end{array}$ & ( ) & ( ) & ( ) & ( ) & $(\quad)$ \\
\hline Coleta regular & ( ) & ( ) & ( ) & ) & ) \\
\hline Coleta seletiva & ( ) & ( ) & ( ) & ( ) & ( ) \\
\hline Transporte & $($ ) & ( ) & ( ) & $($ ) & $($ ) \\
\hline $\begin{array}{l}\text { Transferência de } \\
\text { resíduos (construção de } \\
\text { estações para este } \\
\text { serviço) }\end{array}$ & ( ) & ( ) & ( ) & ( ) & ( ) \\
\hline $\begin{array}{l}\text { Triagem para } \\
\text { recuperação de materiais } \\
\text { recicláveis ou pátio de } \\
\text { compostagem } \\
\text { (construção de galpão } \\
\text { para este serviço) }\end{array}$ & ( ) & ( ) & ( ) & ( ) & ( ) \\
\hline $\begin{array}{l}\text { Disposição final - } \\
\text { aterros sanitários } \\
\text { (construção, operação e }\end{array}$ & ( ) & ( ) & ( ) & ( ) & $($ ) \\
\hline
\end{tabular}




\begin{tabular}{|c|c|c|c|c|c|}
\hline ( manutenção) & & & & & \\
\hline $\begin{array}{l}\text { Fiscalização e } \\
\text { monitoramento }\end{array}$ & () & () & $(\quad)$ & $(\quad)$ & ( ) \\
\hline Regulação & $(\quad)$ & $(\quad)$ & () & () & ( ) \\
\hline $\begin{array}{l}\text { Contratação e formação } \\
\text { de Quadro técnico e } \\
\text { operacional }\end{array}$ & () & () & () & ( ) & ( ) \\
\hline $\begin{array}{l}\text { Outra fonte de recursos } \\
\text { (especifique) }\end{array}$ & & & & & \\
\hline
\end{tabular}

Quais os desafios encontrados pelo Consórcio para manutenção dos serviços previstos no contrato do Consórcio Público? (marque todas alternativas que forem necessárias):

( ) Inadimplência de um dos municípios impede o recebimento de financiamento pelo Consórcio;

( ) Lentidão na ratificação do Protocolo de intenções pelas Câmaras Municipais.

( ) Limitação de recursos financeiros;

( ) Dificuldade no estabelecimento de cobrança de taxas que possam cobrir os gastos com os serviços;

( ) Estrutura municipal deficitária na parte técnica e de recursos humanos na área de gestão de resíduos sólidos e Consórcios;

( ) Descontinuidade política das Administrações Municipais a cada mudança de governo e interesses políticos;

( ) Falta de incentivos para o município que recebe o aterro sanitário do Consórcio;

( ) Dificuldade em conseguir as licenças ambientais necessárias para a operação;

( ) Falta de comunicação com a população em geral, comunidades vizinhas ao aterro e catadores de materiais recicláveis;

( ) Falta de apoio institucional, jurídico e financeiro estadual.

( ) Outro [ especifique]

Caso deseje, acrescente comentários sobre esta pesquisa:

\section{Quais os dados para contato do Consórcio?}

Nome gerente responsável do Consórcio:

E-mail do Consórcio:

Telefone do Consórcio:

Responsável pelo preenchimento do questionário (opcional, estes dados não serão divulgados):

Nome:

E-mail:

Cargo: 
APÊNDICE D - Contatos dos Consórcios Públicos participantes do Estudo de caso

\begin{tabular}{|c|c|c|}
\hline & Nome do Consórcio Público & E-mail de contato do Consórcio ${ }^{43}$ \\
\hline 1 & $\begin{array}{l}\text { Consórcio Regional de Resíduos Sólidos do Sertão } \\
\text { Alagoano - CRERSSAL }\end{array}$ & crerssal@ outlook.com \\
\hline 2 & $\begin{array}{l}\text { Consórcio Intermunicipal de Desenvolvimento da } \\
\text { Região Norte de Alagoas - Conorte/AL }\end{array}$ & consad.al@hotmail.com \\
\hline 3 & $\begin{array}{l}\text { Consórcio Intermunicipal para Gestão dos Resíduos } \\
\text { Sólidos - CIGRES }\end{array}$ & cigres.al@ hotmail.com \\
\hline 4 & $\begin{array}{l}\text { Consórcio Intermunicipal do Sul do Estado de } \\
\text { Alagoas - CONISUL }\end{array}$ & conisul@conisul.com.br \\
\hline 5 & $\begin{array}{l}\text { Consórcio COMARES - UCV Consórcio Municipal } \\
\text { de Aterro de Resíduos Sólidos }\end{array}$ & - \\
\hline 6 & $\begin{array}{l}\text { Consórcio Intermunicipal Portal da Mata Sul - Portal } \\
\text { Sul Consórcio }\end{array}$ & portalsulconsorcio@gmail.com \\
\hline 7 & $\begin{array}{l}\text { Consórcio Público dos Municípios da Mata Sul } \\
\text { Pernambucana -COMSUL }\end{array}$ & comsulpe@gmail.com \\
\hline 8 & $\begin{array}{l}\text { Consórcio dos Municípios da Mata Norte e Agreste } \\
\text { Setentrional de Pernambuco - Comanas }\end{array}$ & - \\
\hline 9 & $\begin{array}{l}\text { Consórcio de Regionalização da Destinação Final de } \\
\text { Resíduos Sólidos Domiciliares dos Municípios da } \\
\text { Região Sul e Serrana - CONSUL }\end{array}$ & - \\
\hline 10 & $\begin{array}{l}\text { Consórcio Público de Regionalização da Destinação } \\
\text { Final de Resíduos Sólidos Domiciliares dos } \\
\text { Municípios da Região Doce Oeste - CONDOESTE }\end{array}$ & - \\
\hline 11 & $\begin{array}{l}\text { Consórcio de Regionalização da Destinação Final de } \\
\text { Resíduos Sólidos da Região Norte do ES - } \\
\text { CONORTE }\end{array}$ & conorte1@hotmail.com \\
\hline 12 & $\begin{array}{l}\text { Consórcio Intermunicipal de Reciclagem e } \\
\text { Compostagem do Lixo }\end{array}$ & consorcioutc@viareal.com.br \\
\hline 13 & $\begin{array}{l}\text { Consórcio Público de Gestão de Resíduos Sólidos da } \\
\text { Baixada Fluminense }\end{array}$ & zilto@terra.com.br \\
\hline 14 & $\begin{array}{l}\text { Consórcio Público de Gestão de Resíduos Sólidos } \\
\text { Serrana II }\end{array}$ & consorcioserrana@gmail.com \\
\hline 15 & $\begin{array}{l}\text { Consórcio Público de Gestão de Resíduos Sólidos } \\
\text { Serrana I }\end{array}$ & professorleandro@uol.com.br \\
\hline 16 & $\begin{array}{l}\text { Consórcio Público de Gestão de Resíduos Sólidos } \\
\text { Noroeste Fluminense }\end{array}$ & silvestre.almeida@hotmail.com \\
\hline 17 & $\begin{array}{l}\text { Consórcio Público de Gestão de Resíduos Sólidos } \\
\text { Vale do Café }\end{array}$ & tatianesmmapmv@gmail.com \\
\hline
\end{tabular}

${ }^{43}$ Os e-mails divulgados foram fornecidos pelos Consórcios Públicos em uma das perguntas do questionário: “Quais os dados para contato do Consórcio?" Não estão sendo divulgados os e-mails das pessoas que preencheram o questionário. 


\begin{tabular}{|l|l|l|}
\hline & \multicolumn{1}{|c|}{ Nome do Consórcio Público } & \multicolumn{1}{c|}{ E-mail de contato do Consórcio } \\
\hline 18 & $\begin{array}{l}\text { Consórcio Público de Gestão de Resíduos Sólidos Sul } \\
\text { Fluminense II }\end{array}$ & solangesp@ig.com.br \\
\hline 19 & $\begin{array}{l}\text { Consórcio Público de Gestão de Resíduos Centro Sul } \\
\text { Fluminense I }\end{array}$ & professor.didi@ yahoo.com.br \\
\hline 20 & Consórcio Público de Gestão de Resíduos Lagos I & $\begin{array}{l}\text { claudinhabotafogo@ @mail.com; } \\
\text { arqanapaula_5@ @otmail.com }\end{array}$ \\
\hline 21 & $\begin{array}{l}\text { Consórcio Intermunicipal de Saneamento Básico da } \\
\text { Região do Circuito das Águas - CISBRA }\end{array}$ & - \\
\hline 22 & $\begin{array}{l}\text { Consórcio Intermunicipal de Manejo de Resíduos } \\
\text { Sólidos da Região Metropolitana de Campinas - } \\
\text { Consimares }\end{array}$ & - \\
\hline 23 & Consórcio Intermunicipal Esmeralda Pinhal da Serra & gildo.fazenda@esmeraldars.net \\
\hline 24 & $\begin{array}{l}\text { Consórcio Intermunicipal de Gestão de Resíduos } \\
\text { Sólidos - CIGRES }\end{array}$ & Nair.cigres@ @otmail.com \\
\hline 25 & Consórcio Intermunicipal para Aterro Sanitário - Cias & amunorpi@ uol.com.br \\
\hline 26 & Consórcio Intermunicipal Caiuá Ambiental & - \\
\hline 27 & Consórcio Intermunicipal do Contestado - COINCO & - \\
\hline 28 & $\begin{array}{l}\text { Consórcio Intermunicipal do Médio Vale do Itajaí - } \\
\text { CIMVI }\end{array}$ & - \\
\hline 29 & $\begin{array}{l}\text { Consórcio Intermunicipal de Gerenciamento } \\
\text { Ambiental Iberí }\end{array}$ & administrativo@ibere.org.br \\
\hline
\end{tabular}


Apêndice E - Dados sobre população, IDHM e PIB dos 29 Consórcios Públicos Analisados ${ }^{44}$

\begin{tabular}{|c|c|c|c|c|c|c|c|c|c|}
\hline \multicolumn{10}{|c|}{ NORDESTE } \\
\hline & Nome do Consórcio Público: & $\begin{array}{l}\text { Estado onde está } \\
\text { localizado o } \\
\text { Consórcio } \\
\text { Público: }\end{array}$ & $\begin{array}{l}\text { Quantidade } \\
\text { de } \\
\text { municípios }\end{array}$ & $\begin{array}{l}\text { Quais os municípios } \\
\text { integrantes do } \\
\text { Consórcio? }\end{array}$ & População 2010 & $\begin{array}{l}\text { Pib a preços } \\
\text { correntes } \\
\text { (mil reais) } \\
2010\end{array}$ & $\begin{array}{l}\text { Área da } \\
\text { Unidade } \\
\text { territorial } \\
(\mathbf{k m 2}) \\
\end{array}$ & \begin{tabular}{|l} 
Densidade \\
demográfica \\
$(\mathrm{hab} / \mathrm{km} 2)$ \\
\end{tabular} & \begin{tabular}{|l} 
Índice de \\
Desenvolvim \\
ento \\
Humano \\
Municipal - \\
2010 (IDHM \\
2010 ) \\
\end{tabular} \\
\hline \multirow{10}{*}{1} & \multirow{8}{*}{$\begin{array}{c}\text { CRERSSAL- Consórcio } \\
\text { Regional de Resíduos Sólidos } \\
\text { do Sertão Alagoano }\end{array}$} & \multirow{8}{*}{ Alagoas } & \multirow{8}{*}{8} & Água Branca & 9.377 & 68.127 & 454,63 & 42,6 & 0,549 \\
\hline & & & & Canapi & 17.250 & 59.418 & 574,57 & 30 & 0,506 \\
\hline & & & & Delmiro Gouveia & 48.096 & 309.911 & 607,81 & 79,1 & 0,612 \\
\hline & & & & Inhapi (sede) & 17.898 & 58.417 & 376,86 & 47,5 & 0,484 \\
\hline & & & & Mata Grande & 24.698 & 78.124 & 907,98 & 27,2 & 0,504 \\
\hline & & & & Olho D'Água do Casado & 8.491 & 33.641 & 322,95 & 26,3 & 0,565 \\
\hline & & & & Pariconha & 10.264 & 34.386 & 258,53 & 39,7 & 0,548 \\
\hline & & & & Piranhas & 23.045 & 79.908 & 408,11 & 56,5 & 0,589 \\
\hline & & & & TOTAL & 159.119 & 721.932 & 3911,44 & 348,9 & 4,357 \\
\hline & & & & MÉDIA & 19.890 & 4,537 & & 40,68 & 0,545 \\
\hline \multirow{8}{*}{2} & \multirow{8}{*}{$\begin{array}{l}\text { Consórcio intermunicipal de } \\
\text { desenvolvimento do norte } \\
\text { de alagoas - Conorte/al }\end{array}$} & \multirow{8}{*}{ Alagoas } & \multirow{8}{*}{15} & Campestre & 6.598 & 28.221 & 66,39 & 99,4 & 0,559 \\
\hline & & & & Colônia Leopoldina & 20.019 & 111.862 & 207,89 & 96,3 & 0,517 \\
\hline & & & & Flexeiras & 12.325 & 51.245 & 333,22 & 37 & 0,527 \\
\hline & & & & Jacuípe & 6.997 & 32.726 & 210,38 & 33,3 & 0,548 \\
\hline & & & & Japaratinga & 7.754 & 33.921 & 85,95 & 90,2 & 0,570 \\
\hline & & & & Joaquim gomes & 22.575 & 78.056 & 298,29 & 75,7 & 0,531 \\
\hline & & & & Jundiá & 4.202 & 25.450 & 92,22 & 45,6 & 0,562 \\
\hline & & & & Maragogi & 28.749 & 129.616 & 334,04 & 86,1 & 0,574 \\
\hline
\end{tabular}

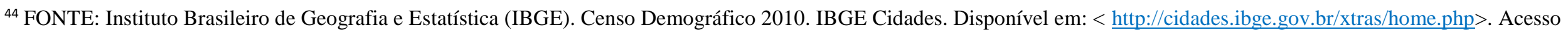
em: 13 jun. 2014. 


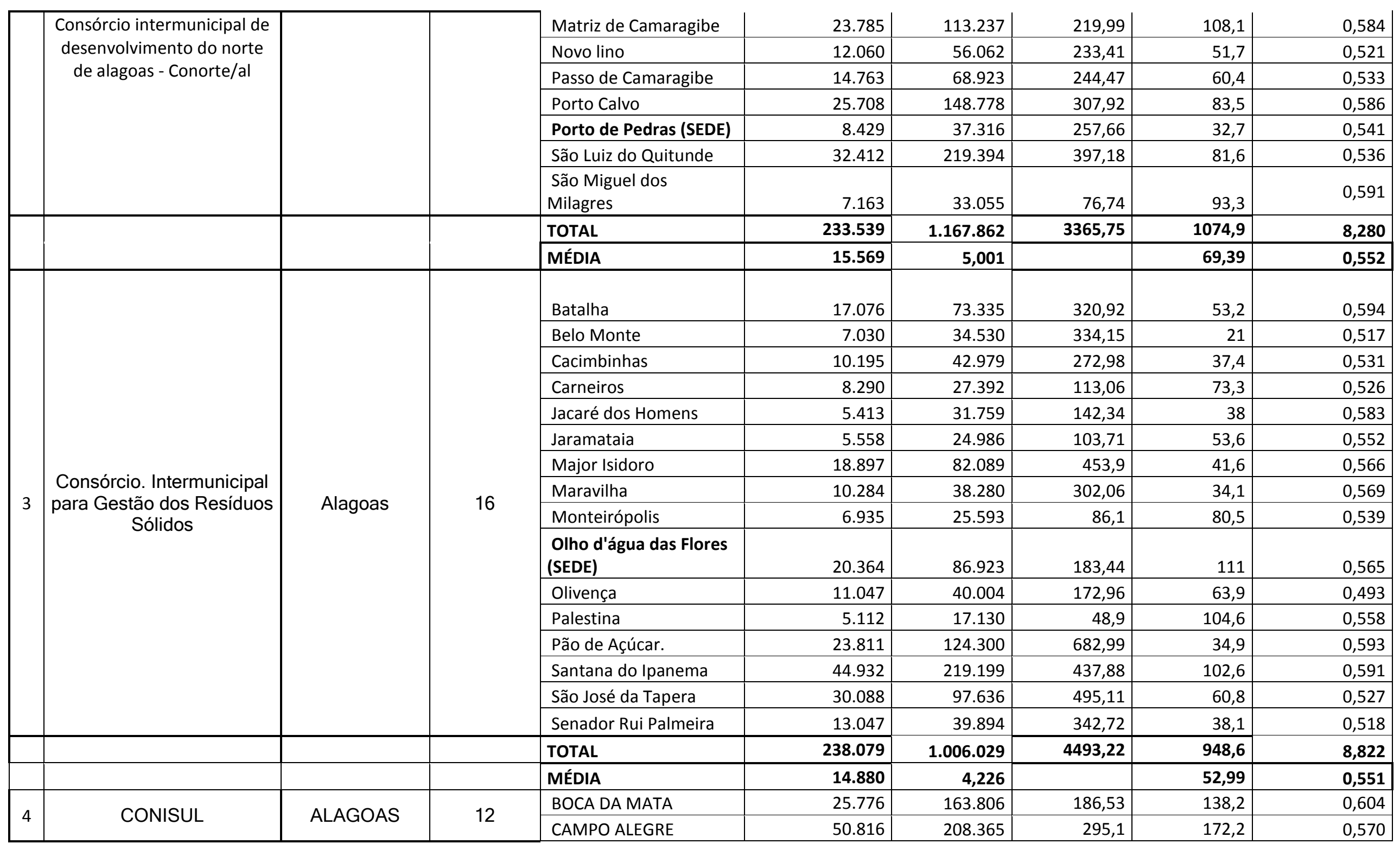




\begin{tabular}{|c|c|c|c|c|c|c|c|c|c|}
\hline & & & & CORURIPE & 52.130 & 541.955 & 918,21 & 56,8 & 0,626 \\
\hline & & & & FELIZ DESERTO & 4.345 & 36.982 & 91,84 & 47,3 & 0,565 \\
\hline & & & & JEQUIA DA PRAIA & 12.029 & 117.396 & 351,61 & 34,2 & 0,556 \\
\hline & & & & JUNQUEIRO & 23.836 & 110.696 & 241,59 & 98,7 & 0,575 \\
\hline & & & & PENEDO (SEDE) & 60.378 & 351.296 & 689,16 & 87,6 & 0,630 \\
\hline & & & & PIAÇABUÇU & 17.203 & 77.910 & 240,01 & 71,7 & 0,572 \\
\hline & & & & $\begin{array}{l}\text { PORTO REAL DO } \\
\text { COLEGIO }\end{array}$ & 19.334 & 69.214 & 240,52 & 80,4 & 0,551 \\
\hline & & & & SÃO BRÁS & 6.718 & 52.504 & 139,95 & 48 & 0,572 \\
\hline & & & & SÃO SEBASTIÃO & 32.010 & 137.442 & 315,11 & 101,6 & 0,549 \\
\hline & & & & TEOTÔNIO VILELA & 41.152 & 214.585 & 297,88 & 138,2 & 0,564 \\
\hline & & & & TOTAL & 345.727 & 2.082 .151 & $4.007,51$ & $1.074,9$ & 6,934 \\
\hline & & & & MÉDIA & 28.811 & 6,023 & & 86,27 & 0,578 \\
\hline 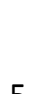 & $\begin{array}{c}\text { CONSÓRCIO COMARES } \\
\text { - UCV Consórcio }\end{array}$ & Craró & 3 & Beberibe & 49.311 & 302.614 & $1.623,89$ & 30,4 & 0,638 \\
\hline 5 & Municipal de Aterro de & Ceara & 3 & Cascavel (SEDE) & 66.142 & 444.656 & 837,33 & 79 & 0,646 \\
\hline & & & & Pindoretama & 18.683 & 89.191 & 72,96 & 256,1 & 0,636 \\
\hline & & & & TOTAL & 134.136 & 836.461 & $2.534,18$ & 365,5 & 1,920 \\
\hline & & & & MÉDIA & 44.712 & 6,236 & & 52,93 & 0,640 \\
\hline & & & & Barreiros & 40.732 & 201.581 & 233,37 & 174,5 & 0,586 \\
\hline & Consórcio Intermunicipal & & & Gameleira & 27.912 & 115.950 & 255,96 & 109,1 & 0,602 \\
\hline 6 & Portal da Mata Sul - Portal & Pernambuco & 5 & Rio Formoso (SEDE) & 22.151 & 156.494 & 227,46 & 97,4 & 0,613 \\
\hline & & & & Sirinhaém & 40.296 & 320.404 & 374,61 & 107,6 & 0,597 \\
\hline & & & & Tamandaré & 20.715 & 138.208 & 214,31 & 96,7 & 0,593 \\
\hline & & & & TOTAL & 151.806 & 932.637 & $1.305,71$ & 585,3 & 2,991 \\
\hline & & & & MÉDIA & 30.361 & 6,144 & & 116,263 & 0,598 \\
\hline 7 & & Pernambuco & 22 & Água Preta & 33.095 & 144.064 & 533,33 & 62,1 & 0,553 \\
\hline & & & & Amaraji & 21.939 & 113.219 & 234,96 & 93,4 & 0,580 \\
\hline
\end{tabular}




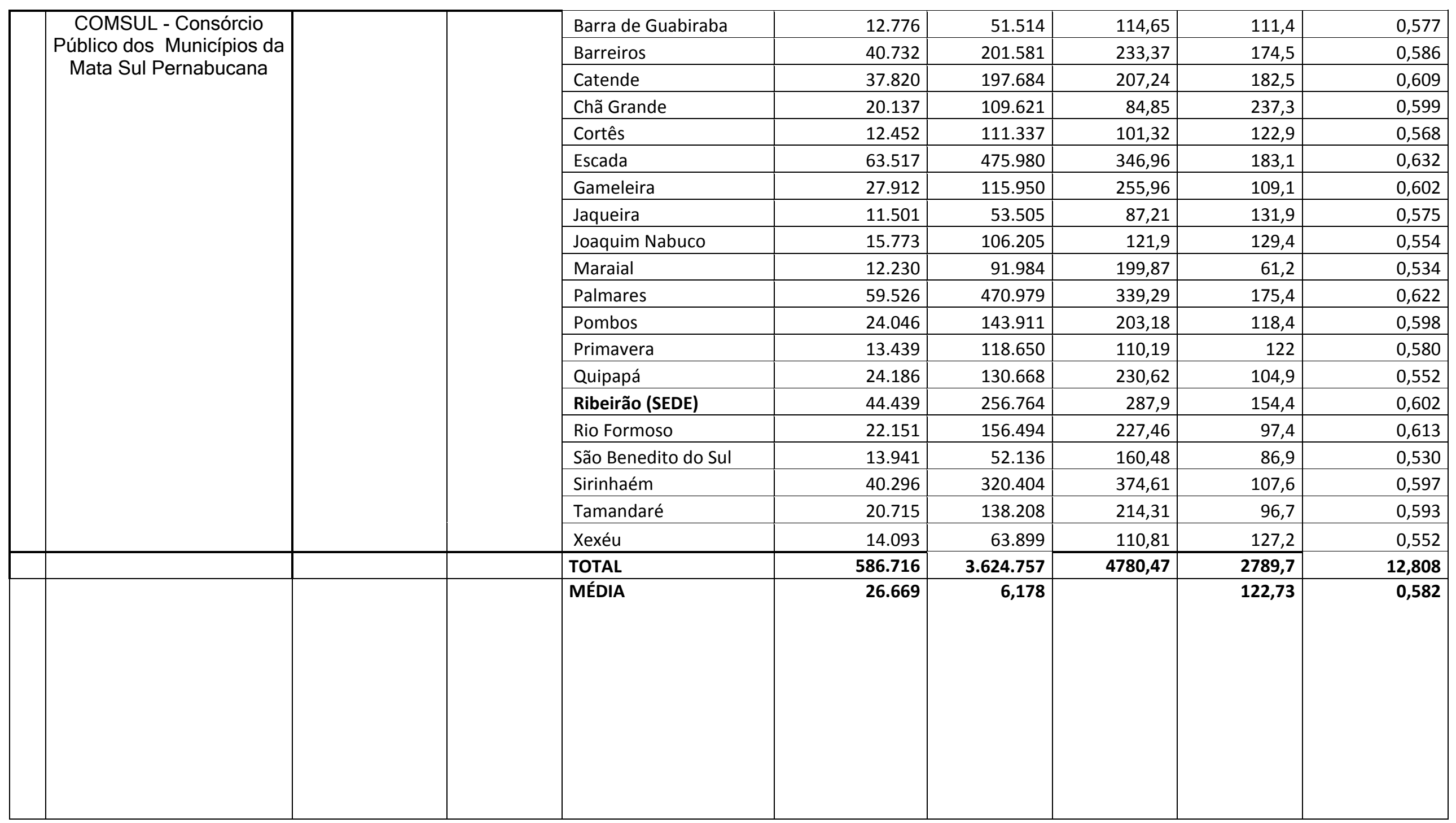




\begin{tabular}{|c|c|c|c|c|c|c|c|c|c|}
\hline & Nome do Consórcio Público: & $\begin{array}{l}\text { Estado onde está } \\
\text { localizado o } \\
\text { Consórcio Público: }\end{array}$ & $\begin{array}{l}\text { Quantidade de } \\
\text { municípios }\end{array}$ & $\begin{array}{l}\text { Quais os municípios } \\
\text { integrantes do Consórcio? }\end{array}$ & População 2010 & \begin{tabular}{|l} 
Pib a preços \\
correntes (mil \\
reais) 2010 \\
\end{tabular} & $\begin{array}{l}\text { Área da Unidade } \\
\text { territorial (km2) }\end{array}$ & \begin{tabular}{|l} 
Densidade \\
demográfica \\
(hab/km2) \\
\end{tabular} & \begin{tabular}{|l|} 
Índice de \\
Desenvolvime \\
nto Humano \\
Municipal - \\
2010 (IDHM \\
2010) \\
\end{tabular} \\
\hline \multirow{24}{*}{8} & \multirow{24}{*}{$\begin{array}{l}\text { CONSÓRCIO DOS } \\
\text { MUNICÍPIOS DA MATA } \\
\text { NORTE E AGRESTE } \\
\text { SETENTRIONAL DE } \\
\text { PERNAMBUCO } \\
\text { (COMANAS) }\end{array}$} & \multirow{24}{*}{ PERNAMBUCO } & \multirow{24}{*}{24} & ALIANÇA & 37.415 & 187.875 & 272,79 & 137,2 & 0,604 \\
\hline & & & & CAMUTANGA & 8.156 & 150.007 & 37,52 & 217,4 & 0,606 \\
\hline & & & & CARPINA (SEDE) & 74.858 & 582.380 & 144,93 & 516,5 & 0,680 \\
\hline & & & & CASINHAS & 13.766 & 67.562 & 115,87 & 118,8 & 0,567 \\
\hline & & & & CHÃ DE ALEGRIA & 12.404 & 57.096 & 48,55 & 255,5 & 0,604 \\
\hline & & & & CONDADO & 24.282 & 118.466 & 89,65 & 270,9 & 0,602 \\
\hline & & & & FEIRA NOVA & 20.571 & 86.362 & 107,73 & 191 & 0,600 \\
\hline & & & & FERREIROS & 11.430 & 66.797 & 89,35 & 127,9 & 0,622 \\
\hline & & & & GLÓRIA DO GOITÁ & 29.019 & 119.101 & 231,83 & 125,2 & 0,604 \\
\hline & & & & GOIANA & 75.644 & 738.736 & 501,88 & 150,7 & 0,651 \\
\hline & & & & ITAMBÉ & 35.398 & 202.361 & 304,81 & 116,1 & 0,575 \\
\hline & & & & ITAQUITINGA & 15.692 & 94.895 & 103,42 & 151,7 & 0,586 \\
\hline & & & & LAGOA Do ITAENGA & 20.659 & 214.837 & 57,28 & 360,7 & 0,602 \\
\hline & & & & LAGOA DO CARRO & 16.007 & 71.130 & 69,67 & 229,8 & 0,609 \\
\hline & & & & LIMOEIRO & 55.439 & 325.911 & 273,74 & 202,5 & 0,663 \\
\hline & & & & MACHADOS & 13.596 & 67.918 & 60,04 & 226,5 & 0,578 \\
\hline & & & & NAZARÉ DA MATA & 30.796 & 233.378 & 150,26 & 205 & 0,662 \\
\hline & & & & PASSIRA & 28.628 & 128.362 & 326,76 & 87,6 & 0,592 \\
\hline & & & & PAUDALHO & 51.357 & 265.388 & 277,51 & 185,1 & 0,639 \\
\hline & & & & SALGADINHO & 9.312 & 53.841 & 87,22 & 106,8 & 0,534 \\
\hline & & & & TIMBAÚBA & 53.825 & 448.594 & 291,52 & 184,6 & 0,618 \\
\hline & & & & TRACUNHAÉM & 13.055 & 71.624 & 118,39 & 110,3 & 0,605 \\
\hline & & & & VERTENTE DO LÉRIO & 7.873 & 63.606 & 73,63 & 106,9 & 0,563 \\
\hline & & & & VICÊNCIA & 30.732 & 184.386 & 228,02 & 134,8 & 0,605 \\
\hline & & & & TOTAL & 689.914 & 4.600 .613 & 4062,37 & 4519,5 & 14,571 \\
\hline & & & & MÉDIA & 28.746 & 6,668 & & 169,83 & 0,607 \\
\hline
\end{tabular}




\begin{tabular}{|c|c|c|c|c|c|c|c|c|c|}
\hline \multicolumn{10}{|c|}{ SUDESTE } \\
\hline & Nome do Consórcio Público: & $\begin{array}{l}\text { Estado onde está } \\
\text { localizado o } \\
\text { Consórcio } \\
\text { Público: } \\
\end{array}$ & $\begin{array}{l}\text { Quantidade } \\
\text { de } \\
\text { municípios } \\
\end{array}$ & $\begin{array}{l}\text { Quais os municípios } \\
\text { integrantes do } \\
\text { Consórcio? }\end{array}$ & População 2010 & $\begin{array}{l}\text { PIB a preços } \\
\text { correntes } \\
2010 \\
\end{array}$ & \begin{tabular}{|l} 
Área da \\
Unidade \\
territorial \\
(km2) \\
\end{tabular} & $\begin{array}{l}\text { Densidade } \\
\text { demográfic } \\
\text { a (hab/km2) } \\
\end{array}$ & $\begin{array}{l}\text { Índice de } \\
\text { Desenvolviment } \\
\text { o Humano } \\
\text { Municipal - 2010 } \\
\text { (IDHM 2010) }\end{array}$ \\
\hline \multirow{27}{*}{1} & \multirow{27}{*}{$\begin{array}{l}\text { Consórcio de } \\
\text { regionalização da } \\
\text { destinação final de } \\
\text { resíduos sólidos } \\
\text { domiciliares dos } \\
\text { municípios da região Sul e } \\
\text { Serrana - CONSUL }\end{array}$} & \multirow{27}{*}{ Espírito Santo } & \multirow{27}{*}{28} & Alegre & 30.768 & 245.048 & 772 & 39,9 & 0,721 \\
\hline & & & & Alfredo Chaves & 13.955 & 159.933 & 615,79 & 22,7 & 0,710 \\
\hline & & & & Anchieta & 23.902 & 4.185.902 & 409,23 & 58,4 & 0,730 \\
\hline & & & & Apiacá & 7.512 & 51.022 & 193,99 & 38,7 & 0,673 \\
\hline & & & & Atílio Vivacqua & 9.850 & 117.323 & 223,45 & 44,1 & 0,708 \\
\hline & & & & Bom Jesus do Norte & 9.476 & 76.401 & 89,08 & 106,4 & 0,734 \\
\hline & & & & Brejetuba & 11.915 & 133.898 & 344,17 & 34,6 & 0,656 \\
\hline & & & & Castelo (sede) & 34.747 & 382.187 & 664,06 & 52,3 & 0,726 \\
\hline & & & & Conceição do Castelo & 11.681 & 111.102 & 369,23 & 31,6 & 0,670 \\
\hline & & & & Divino de São Lourenço & 4.516 & 36.857 & 173,88 & 26 & 0,632 \\
\hline & & & & Dores do Rio Preto & 6.397 & 53.389 & 159,3 & 40,2 & 0,654 \\
\hline & & & & Guaçuí & 27.851 & 238.693 & 468,34 & 59,5 & 0,703 \\
\hline & & & & Ibatiba & 22.366 & 188.892 & 240,54 & 93 & 0,647 \\
\hline & & & & Ibitirama & 8.957 & 76.751 & 329,87 & 27,2 & 0,622 \\
\hline & & & & Iconha & 12.523 & 161.221 & 203,53 & 61,5 & 0,729 \\
\hline & & & & Irupi & 11.723 & 105.613 & 184,55 & 63,5 & 0,637 \\
\hline & & & & Itapemirim & 30.988 & 806.480 & 561,87 & 55,2 & 0,654 \\
\hline & & & & lúna & 27.328 & 233.041 & 461,08 & 59,3 & 0,666 \\
\hline & & & & Jerônimo Monteiro & 10.879 & 78.575 & 161,98 & 67,2 & 0,698 \\
\hline & & & & Marataízes & 34.140 & 471.868 & 133,08 & 256,6 & 0,696 \\
\hline & & & & Mimoso do Sul & 25.902 & 251.057 & 869,43 & 29,8 & 0,670 \\
\hline & & & & Muniz Freire & 18.397 & 162.909 & 679,32 & 27,1 & 0,645 \\
\hline & & & & Muqui & 14.396 & 100.867 & 327,49 & 44 & 0,694 \\
\hline & & & & Presidente Kennedy & 10.314 & 1.607 .473 & 583,93 & 17,7 & 0,657 \\
\hline & & & & Rio Novo do Sul & 11.325 & 100.685 & 204,36 & 55,4 & 0,711 \\
\hline & & & & São José do Calçado & 10.408 & 82.704 & 273,49 & 38,1 & 0,688 \\
\hline & & & & Vargem Alta & 19.130 & 204.073 & 413,63 & 46,3 & 0,663 \\
\hline
\end{tabular}




\begin{tabular}{|c|c|c|c|c|c|c|c|c|c|}
\hline & & & & \begin{tabular}{|l|} 
Venda Nova do \\
Imigrante \\
\end{tabular} & 20.447 & 297.274 & 185,91 & 110 & 0,728 \\
\hline & & & & TOTAL & 481.793 & 10.721 .238 & 10296,58 & 1606,3 & 19,122 \\
\hline & & & & MÉDIA & 17.207 & 22,253 & & 46,79 & 0,683 \\
\hline \multirow{21}{*}{2} & \multirow{21}{*}{$\begin{array}{l}\text { Consórcio Público de } \\
\text { regionalização da } \\
\text { destinação final de } \\
\text { resíduos sólidos } \\
\text { domiciliares dos } \\
\text { municípios da Regiao } \\
\text { Doce Oeste - } \\
\text { CONDOESTE }\end{array}$} & \multirow{21}{*}{ Espírito Santo } & \multirow{21}{*}{21} & Afonso Cláudio & 31.091 & 244.436 & 951,42 & 32,7 & 0,667 \\
\hline & & & & Águia Branca & 9.519 & 111.381 & 454,45 & 21 & 0,678 \\
\hline & & & & Alto Rio Novo & 7.317 & 54.207 & 227,63 & 32,1 & 0,664 \\
\hline & & & & Baixo Guandu & 29.081 & 277.532 & 917,07 & 31,7 & 0,702 \\
\hline & & & & Colatina (sede) & 111.788 & 1.835 .286 & $1.416,80$ & 78,9 & 0,746 \\
\hline & & & & Governador Lindenberg & 10.869 & 94.087 & 359,98 & 30,2 & 0,694 \\
\hline & & & & Ibiraçu & 11.178 & 193.615 & 201,25 & 55,5 & 0,726 \\
\hline & & & & Itaguaçu & 14.134 & 141.886 & 531,5 & 26,6 & 0,702 \\
\hline & & & & Itarana & 10.881 & 103.734 & 298,76 & 36,4 & 0,684 \\
\hline & & & & João Neiva & 15.809 & 208.886 & 284,73 & 55,5 & 0,753 \\
\hline & & & & Laranja da Terra & 10.826 & 81.200 & 458,37 & 23,6 & 0,656 \\
\hline & & & & Linhares & 141.306 & 2.710 .150 & $3.504,14$ & 40,3 & 0,724 \\
\hline & & & & Mantenópolis & 13.612 & 87.352 & 321,42 & 42,4 & 0,657 \\
\hline & & & & Marilândia & 11.107 & 143.184 & 309,02 & 35,9 & 0,696 \\
\hline & & & & Pancas & 21.548 & 141.121 & 829,94 & 26 & 0,667 \\
\hline & & & & Santa Maria de Jetibá & 34.176 & 566.325 & 735,58 & 46,5 & 0,671 \\
\hline & & & & Santa Tereza & 21.823 & 233.981 & 683,16 & 31,9 & 0,714 \\
\hline & & & & São Domingos do Norte & 8.001 & 94.085 & 298,71 & 26,8 & 0,682 \\
\hline & & & & São Gabriel da Palha & 31.859 & 300.932 & 434,89 & 73,3 & 0,709 \\
\hline & & & & São Roque do Canaã & 11.273 & 89.775 & 342,01 & 33 & 0,700 \\
\hline & & & & Vila Valério & 13.830 & 194.436 & 470,1 & 29,4 & 0,675 \\
\hline & & & & TOTAL & 571.028 & 7.907 .591 & 14030,93 & 809,7 & 14,567 \\
\hline & & & & MÉDIA & 27.192 & 13,848 & & 40,70 & 0,694 \\
\hline 3 & Consórsio de & Espírito Santo & 15 & Água Doce do Norte & 11.771 & 81.445 & 473,73 & 24,9 & 0,652 \\
\hline
\end{tabular}




\begin{tabular}{|c|c|c|c|c|c|c|c|c|c|}
\hline & \multirow{14}{*}{$\begin{array}{c}\text { regionalização da } \\
\text { destinação final de } \\
\text { resíduos sólidos da região } \\
\text { norte do ES - CONORTE }\end{array}$} & & & Barra de São Francisco & 40.649 & 432.800 & 941,8 & 43,2 & 0,683 \\
\hline & & & & Boa Esperança (sede) & 14.199 & 151.920 & 428,5 & 33,1 & 0,679 \\
\hline & & & & Conceição da Barra & 28.449 & 489.582 & $1.184,91$ & 24 & 0,681 \\
\hline & & & & Ecoporanga & 23.212 & 261.145 & $2.285,37$ & 10,2 & 0,662 \\
\hline & & & & Jaguaré & 24.678 & 395.934 & 659,75 & 37,4 & 0,678 \\
\hline & & & & Montanha & 17.849 & 267.631 & $1.098,92$ & 16,2 & 0,667 \\
\hline & & & & Mucurici & 5.655 & 70.648 & 540,19 & 10,5 & 0,666 \\
\hline & & & & Nova Venécia & 46.031 & 550.086 & $1.442,16$ & 31,9 & 0,712 \\
\hline & & & & Pedro Canário & 23.794 & 212.101 & 433,88 & 54,8 & 0,654 \\
\hline & & & & Pinheiros & 23.895 & 456.500 & 973,14 & 24,6 & 0,673 \\
\hline & & & & Ponto Belo & 6.979 & 64.463 & 360,66 & 19,4 & 0,669 \\
\hline & & & & São Mateus & 109.028 & 1.188 .176 & $2.338,73$ & 46,6 & 0,735 \\
\hline & & & & Sooretama & 23.843 & 322.043 & 586,42 & 40,7 & 0,662 \\
\hline & & & & Vila Pavão & 8.672 & 111.065 & 433,26 & 20 & 0,681 \\
\hline & & & & TOTAL & 408.704 & 5.055 .539 & 14181,42 & 437,5 & 10,154 \\
\hline \multirow{9}{*}{4} & & & & MÉDIA & 27.247 & 12,370 & & 28,82 & 0,677 \\
\hline & \multirow{6}{*}{$\begin{array}{c}\text { CONSÓRCIO } \\
\text { INTERMUNICIPAL DE } \\
\text { RECICLAGEM E } \\
\text { COMPOSTAGEM DO } \\
\text { LIXO }\end{array}$} & \multirow{6}{*}{$\begin{array}{l}\text { MINAS } \\
\text { GERAIS }\end{array}$} & \multirow{6}{*}{6} & CARANAÍBA & 3.288 & 19.398 & 159,95 & 20,6 & 0,634 \\
\hline & & & & CARANDAÍ & 23.346 & 305.244 & 485,73 & 48,1 & 0,697 \\
\hline & & & & CASA GRANDE & 2.244 & 20.180 & 157,73 & 14,2 & 0,652 \\
\hline & & & & $\begin{array}{l}\text { CRISTIANO OTONI } \\
\text { (sede) }\end{array}$ & 5.007 & 42.845 & 132,87 & 37,7 & 0,695 \\
\hline & & & & QUELUZITO & 1.861 & 21.091 & 153,56 & 12,1 & 0,682 \\
\hline & & & & SANTANA DOS MONTES & 3.822 & 21.856 & 196,57 & 19,4 & 0,647 \\
\hline & & & & TOTAL & 39.568 & 430.614 & 1286,41 & 152,1 & 4,007 \\
\hline & & & & MÉDIA & 6.595 & 10,883 & & 30,76 & 0,668 \\
\hline \multirow{7}{*}{5} & \multirow{6}{*}{$\begin{array}{l}\text { Consórcio Público de } \\
\text { Gestão de Resíduos } \\
\text { Sólidos da Baixada } \\
\text { Fluminense }\end{array}$} & \multirow{6}{*}{ Rio de Janeiro } & \multirow{6}{*}{6} & Belford Roxo & 469.332 & 4.490 .432 & 77,82 & $6.031,40$ & 0,684 \\
\hline & & & & Duque de Caxias & 855.048 & 26.441 .151 & 467,62 & $1.828,50$ & 0,711 \\
\hline & & & & Mesquita & 168.376 & 1.537 .752 & 39,06 & $4.310,50$ & 0,737 \\
\hline & & & & Nilópolis. & 157.425 & 1.685 .587 & 19,39 & $8.117,60$ & 0,753 \\
\hline & & & & Nova Iguaçu & 796.257 & 9.543 .072 & 521,25 & $1.527,60$ & 0,713 \\
\hline & & & & São João de Meriti (sede) & 458.673 & 4.873 .458 & 35,22 & $13.024,60$ & 0,719 \\
\hline & & & & TOTAL & 2.905 .111 & 48.571 .452 & 1160,36 & $34.840,20$ & 4,317 \\
\hline
\end{tabular}




\begin{tabular}{|c|c|c|c|c|c|c|c|c|c|}
\hline & & & & MÉDIA & 484.185 & 16,719 & & $2.503,63$ & 0,720 \\
\hline \multirow{8}{*}{6} & \multirow{6}{*}{$\begin{array}{l}\text { Consórcio Público de } \\
\text { Gestão de Resíduos } \\
\text { Sólidos Serrana II }\end{array}$} & \multirow{6}{*}{ Rio de Janeiro } & \multirow{6}{*}{6} & Areal & 11.423 & 221.574 & 110,92 & 103 & 0,684 \\
\hline & & & & $\begin{array}{l}\text { Comendador Levy } \\
\text { Gasparian }\end{array}$ & 8.180 & 130.623 & 106,89 & 76,5 & 0,685 \\
\hline & & & & Paraíba do Sul & 41.084 & 536.198 & 580,53 & 70,8 & 0,702 \\
\hline & & & & Petrópolis & 295.917 & 7.059 .696 & 795,8 & 371,9 & 0,745 \\
\hline & & & & Sapucaia & 17.525 & 404.775 & 541,71 & 32,4 & 0,675 \\
\hline & & & & Três Rios (sede) & 77.432 & 1.738 .084 & 326,14 & 237,4 & 0,725 \\
\hline & & & & TOTAL & 451.561 & 10.090 .950 & 2461,99 & 892 & 4,216 \\
\hline & & & & MÉDIA & 75.260 & 22,347 & & 183,41 & 0,703 \\
\hline \multirow{6}{*}{7} & \multirow{4}{*}{$\begin{array}{l}\text { Consórcio Público de } \\
\text { Gestão de Resíduos } \\
\text { Sólidos Serrana I }\end{array}$} & \multirow{4}{*}{ Rio de Janeiro } & \multirow{4}{*}{4} & Carmo & 17.434 & 282.503 & 321,94 & 54,2 & 0,696 \\
\hline & & & & $\begin{array}{l}\text { São José do Vale do Rio } \\
\text { Preto. }\end{array}$ & 20.251 & 649.626 & 220,43 & 91,9 & 0,660 \\
\hline & & & & Sumidouro & 14.900 & 192.770 & 395,52 & 37,7 & 0,611 \\
\hline & & & & Teresópolis (sede) & 163.746 & 2.784 .556 & 770,6 & 212,5 & 0,730 \\
\hline & & & & TOTAL & 216.331 & 3.909 .455 & 1708,49 & 396,3 & 2,697 \\
\hline & & & & MÉDIA & 54.083 & 18,072 & & 126,62 & 0,674 \\
\hline \multirow{14}{*}{8} & \multirow{14}{*}{$\begin{array}{l}\text { Consórcio Público de } \\
\text { Gestão de Resíduos } \\
\text { Sólidos Noroeste } \\
\text { Fluminense }\end{array}$} & \multirow{14}{*}{ Rio de Janeiro } & \multirow{14}{*}{15} & Aperibé & 10.213 & 92.689 & 94,64 & 107,9 & 0,692 \\
\hline & & & & $\begin{array}{l}\text { Bom Jesus do } \\
\text { Itabapoana }\end{array}$ & 35.411 & 410.114 & 598,83 & 59,1 & 0,732 \\
\hline & & & & Cambuci & 14.827 & 161.852 & 561,7 & 26,4 & 0,691 \\
\hline & & & & Cardoso Moreira & 12.600 & 119.470 & 524,63 & 24 & 0,648 \\
\hline & & & & Italva & 14.063 & 135.242 & 293,82 & 47,9 & 0,688 \\
\hline & & & & Itaocara. & 22.899 & 261.095 & 431,34 & 53,1 & 0,713 \\
\hline & & & & Itaperuna & 95.841 & 1.418 .642 & $1.105,34$ & 86,7 & 0,730 \\
\hline & & & & Laje do Muriaé & 7.487 & 77.844 & 249,97 & 30 & 0,668 \\
\hline & & & & Miracema & 26.843 & 260.937 & 304,51 & 88,2 & 0,713 \\
\hline & & & & Natividade & 15.082 & 155.770 & 386,74 & 39 & 0,730 \\
\hline & & & & Porciúncula & 17.760 & 189.953 & 302,03 & 58,8 & 0,697 \\
\hline & & & & Santo Antônio de Pádua & 40.589 & 541.935 & 603,36 & 67,3 & 0,718 \\
\hline & & & & São Fidélis (sede) & 37.543 & 398.683 & $1.031,56$ & 36,4 & 0,691 \\
\hline & & & & São José de Ubá & 7.003 & 74.014 & 250,28 & 28 & 0,652 \\
\hline
\end{tabular}




\begin{tabular}{|c|c|c|c|c|c|c|c|c|c|}
\hline & & & & Varre-Sai & 9.475 & 96.196 & 190,06 & 49,9 & 0,659 \\
\hline & & & & TOTAL & 367.636 & 4.394 .436 & 6928,81 & 802,7 & 10,422 \\
\hline \multirow{5}{*}{$\mathrm{s}$} & \multirow{5}{*}{$\begin{array}{l}\text { Consórcio Público de } \\
\text { Gestão de Resíduos } \\
\text { Sólidos Vale do Café }\end{array}$} & \multirow[b]{5}{*}{ Rio de Janeiro } & \multirow[b]{5}{*}{4} & MÉDIA & 24.509 & 11,953 & & 53,06 & 0,695 \\
\hline & & & & Barra do Piraí. & 94.778 & 1.384 .019 & 578,97 & 163,7 & 0,733 \\
\hline & & & & Rio das Flores & 8.561 & 342.150 & 478,31 & 17,9 & 0,680 \\
\hline & & & & Valença & 71.843 & 991.142 & $1.304,81$ & 55,1 & 0,738 \\
\hline & & & & Vassouras (sede) & 34.410 & 407.809 & 538,13 & 63,9 & 0,714 \\
\hline & & & & TOTAL & 209.592 & 3.125 .120 & $2.900,22$ & 300,6 & 2,865 \\
\hline \multirow{6}{*}{10} & \multirow{5}{*}{$\begin{array}{l}\text { Consórcio Público de } \\
\text { Gestão de Resíduos } \\
\text { Sólidos Sul Fluminense II }\end{array}$} & \multirow{5}{*}{ Rio de Janeiro } & \multirow{5}{*}{4} & MÉDIA & 52.398 & 14,910 & & 72,27 & 0,716 \\
\hline & & & & Itatiaia & 28.783 & 1.409 .954 & 245,15 & 117,4 & 0,737 \\
\hline & & & & Porto Real & 16.592 & 4.868 .607 & 50,75 & 327 & 0,713 \\
\hline & & & & Quatis. & 12.793 & 186.536 & 286,09 & 44,7 & 0,690 \\
\hline & & & & Resende (sede) & 119.769 & 6.417 .158 & $1.095,25$ & 109,4 & 0,768 \\
\hline & & & & TOTAL & 177.937 & 12.882 .255 & 1677,24 & 598,5 & 2,908 \\
\hline \multirow{7}{*}{11} & \multirow{6}{*}{$\begin{array}{l}\text { Consórcio Público de } \\
\text { Gestão de Resíduos } \\
\text { Centro Sul Fluminense I }\end{array}$} & \multirow{6}{*}{ Rio de Janeiro } & \multirow{6}{*}{5} & MÉDIA & 44.484 & 72,398 & & 106,09 & 0,727 \\
\hline & & & & $\begin{array}{l}\text { Engenheiro Paulo de } \\
\text { Frontin }\end{array}$ & 13.237 & 147.801 & 132,94 & 99,6 & 0,722 \\
\hline & & & & Japeri & 95.492 & 918.132 & 81,87 & $1.166,40$ & 0,659 \\
\hline & & & & Mendes & 17.935 & 181.062 & 97,04 & 184,8 & 0,736 \\
\hline & & & & Paracambi (sede) & 47.124 & 499.958 & 179,68 & 262,3 & 0,720 \\
\hline & & & & Queimados. & 137.962 & 1.673 .666 & 75,7 & $1.822,60$ & 0,680 \\
\hline & & & & TOTAL & 311.750 & 3.420 .619 & 567,23 & $3.535,70$ & 3,517 \\
\hline \multirow{6}{*}{12} & \multirow{4}{*}{$\begin{array}{c}\text { Consórcio Público de } \\
\text { Gestão de Resíduos } \\
\text { Lagos I }\end{array}$} & \multirow{4}{*}{ Rio de Janeiro } & \multirow{4}{*}{3} & MÉDIA & 62.350 & 10,972 & & 549,60 & 0,7034 \\
\hline & & & & Araruama (sede) & 112.008 & 1.270 .984 & 638,02 & 175,6 & 0,718 \\
\hline & & & & Saquarema. & 74.234 & 948.819 & 353,57 & 210 & 0,709 \\
\hline & & & & Silva Jardim & 21.349 & 192.649 & 937,55 & 22,8 & 0,654 \\
\hline & & & & TOTAL & 207.591 & 2.412 .452 & 1929,14 & 408,4 & 2,081 \\
\hline & & & & MÉDIA & 69.197 & 11,621 & & 107,61 & 0,694 \\
\hline
\end{tabular}




\begin{tabular}{|c|c|c|c|c|c|c|c|c|c|}
\hline & Nome do Consórcio Público & Estado & $\begin{array}{l}\text { Quantidade } \\
\text { de } \\
\text { municípios }\end{array}$ & $\begin{array}{l}\text { Quais os municípios } \\
\text { integrantes do } \\
\text { Consórcio? }\end{array}$ & População 2010 & PIB 2010 & $\begin{array}{l}\text { Área da } \\
\text { Unidade } \\
\text { territorial } \\
\text { (km2) }\end{array}$ & $\begin{array}{l}\text { Densidade } \\
\text { demográfic } \\
\text { a (hab/km2) }\end{array}$ & $\begin{array}{l}\text { Índice de } \\
\text { Desenvolviment } \\
\text { o Humano } \\
\text { Municipal - 2010 } \\
\text { (IDHM 2010) }\end{array}$ \\
\hline \multirow{13}{*}{13} & \multirow{12}{*}{$\begin{array}{l}\text { Consórcio Intermunicipal } \\
\text { de Saneamento Básico da } \\
\text { Região do Circuito das } \\
\text { Águas - CISBRA }\end{array}$} & \multirow{12}{*}{ São Paulo } & \multirow{12}{*}{12} & Águas de Lindóia & 17.266 & 197.163 & 60,13 & 287,2 & $\begin{array}{r}0,745 \\
\end{array}$ \\
\hline & & & & Amparo (sede) & 65.829 & 2.023 .275 & 445,55 & 147,8 & 0,785 \\
\hline & & & & Itapira & 68.537 & 1.738 .091 & 518,39 & 132,2 & 0,762 \\
\hline & & & & Lindóia & 6.712 & 82.772 & 48,76 & 137,7 & 0,742 \\
\hline & & & & Monte Alegre do Sul & 7.152 & 129.325 & 110,31 & 64,8 & 0,759 \\
\hline & & & & Morungaba & 11.769 & 329.059 & 146,75 & 80,2 & 0,715 \\
\hline & & & & Pedra Bela & 5.780 & 61.835 & 158,59 & 36,5 & 0,677 \\
\hline & & & & Pinhalzinho & 13.105 & 133.605 & 154,53 & 84,8 & 0,725 \\
\hline & & & & Santo Antonio de Posse & 20.650 & 387.228 & 154 & 134,1 & 0,702 \\
\hline & & & & Serra Negra & 26.387 & 361.435 & 203,74 & 129,5 & 0,767 \\
\hline & & & & Socorro & 36.686 & 478.797 & 449,03 & 81,7 & 0,729 \\
\hline & & & & Tuiuti. & 5.930 & 67.474 & 126,7 & 46,8 & 0,728 \\
\hline & & & & TOTAL & 285.803 & 5.990 .059 & 2576,48 & 1363,3 & 8,836 \\
\hline \multirow{9}{*}{14} & & & & MÉDIA & 23.817 & 20,959 & & 110,93 & 0,736 \\
\hline & \multirow{8}{*}{$\begin{array}{l}\text { Consórcio Intermunicipal } \\
\text { de Manejo de Resíduos } \\
\text { Sólidos da Região } \\
\text { Metropolitana de } \\
\text { Campinas (Consimares) }\end{array}$} & \multirow{8}{*}{$\begin{array}{c}\text { Nova Odessa - } \\
\text { SP }\end{array}$} & \multirow{8}{*}{8} & Americana & 210.638 & 6.659 .249 & 133,93 & $1.572,80$ & 0,811 \\
\hline & & & & Capivari & 48.576 & 1.095 .720 & 322,88 & 150,5 & 0,750 \\
\hline & & & & Elias Fausto & 15.775 & 727.635 & 202,69 & 77,8 & 0,695 \\
\hline & & & & Hortolândia & 192.692 & 6.228 .379 & 62,28 & $3.094,20$ & 0,756 \\
\hline & & & & Monte Mor & 48.949 & 1.193 .068 & 240,41 & 203,6 & 0,733 \\
\hline & & & & Nova Odessa (sede) & 51.242 & 1.959 .631 & 74,32 & 689,5 & 0,791 \\
\hline & & & & Santa Bárbara d'Oeste & 180.009 & 3.789 .951 & 270,9 & 664,5 & 0,781 \\
\hline & & & & Sumaré. & 241.311 & 7.848 .922 & 153,5 & $1.572,00$ & 0,762 \\
\hline & & & & TOTAL & 989.192 & 29.502 .555 & 1460,91 & $8.024,90$ & 6,079 \\
\hline & & & & MÉDIA & 123.649 & 29,825 & & 677,11 & 0,760 \\
\hline
\end{tabular}




\begin{tabular}{|c|c|c|c|c|c|c|c|c|c|}
\hline \multicolumn{10}{|c|}{ SUL } \\
\hline & & Estado & $\begin{array}{l}\text { Quantidade } \\
\text { de } \\
\text { municípios }\end{array}$ & $\begin{array}{l}\text { Quais os municípios } \\
\text { integrantes do } \\
\text { Consórcio? }\end{array}$ & População 2010 & PIB 2010 & $\begin{array}{l}\text { Área da } \\
\text { Unidade } \\
\text { territorial } \\
(\text { km2) }\end{array}$ & \begin{tabular}{|l|} 
Densidade \\
demográfic \\
a (hab/km2)
\end{tabular} & $\begin{array}{l}\text { Índice de } \\
\text { Desenvolviment } \\
\text { o Humano } \\
\text { Municipal - 2010 } \\
\text { (IDHM 2010) }\end{array}$ \\
\hline \multirow{2}{*}{\multicolumn{2}{|c|}{$\begin{array}{c}\text { Nome do Consórcio Público: } \\
\text { CONSORCIO } \\
\text { INTERMUNICIPAL } \\
\text { ESMERALDA PINHAL DA } \\
\text { SERRA } \\
\end{array}$}} & \multirow[b]{2}{*}{ RS } & \multirow[t]{2}{*}{ 由 } & ESMERALDA & 3.168 & 84.338 & 829,766 & 3,82 & 0,680 \\
\hline & & & & PINHAL DA SERRA & 2.130 & 161.068 & 437,995 & 4,86 & 0,650 \\
\hline & & & & TOTAL & 5.298 & 245.406 & 1267,761 & 8,68 & 1,330 \\
\hline \multirow{8}{*}{2} & \multirow{7}{*}{$\begin{array}{l}\text { CIGRES -Consórcio } \\
\text { Intermunicipal de Gestão } \\
\text { de Resíduos Sólidos }\end{array}$} & \multirow[b]{7}{*}{ RS } & \multirow[b]{7}{*}{6} & MÉDIA & 2.649 & 46,320 & & 4,18 & 0,665 \\
\hline & & & & Alegria & 4.301 & 56.183 & 172,688 & 24,91 & 0,695 \\
\hline & & & & Chiapetta & 4.044 & 85.453 & 396,551 & 10,20 & 0,732 \\
\hline & & & & Independência & 6.618 & 118.194 & 357,438 & 18,52 & 0,693 \\
\hline & & & & Inhacorá & 2.267 & 32.870 & 114,111 & 19,87 & 0,673 \\
\hline & & & & São José do Inhacorá & 2.200 & 39.230 & 77,806 & 28,28 & 0,747 \\
\hline & & & & Três de Maio & 23.726 & 454.025 & 422,198 & 56,2 & 0,759 \\
\hline & & & & TOTAL & 43.156 & 785.955 & 1540,792 & 157,98 & 4,299 \\
\hline \multirow{7}{*}{3} & \multirow{6}{*}{$\begin{array}{c}\text { Consórcio Intermunicipal } \\
\text { para Aterro Sanitário - } \\
\text { Cias } \\
\end{array}$} & \multirow[b]{6}{*}{ PR } & \multirow[b]{6}{*}{5} & MÉDIA & 7.193 & 18,212 & & 28,01 & 0,717 \\
\hline & & & & Conselheiro Mairinck & 3.636 & 36.929 & 204,705 & 17,76 & 0,707 \\
\hline & & & & Guapirama & 3.891 & 52.359 & 189,100 & 20,58 & 0,702 \\
\hline & & & & Joaquim Távora & 10.736 & 195.576 & 289,173 & 37,13 & 0,700 \\
\hline & & & & Jundiaí do Sul & 3.433 & 41.253 & 320,816 & 10,7 & 0,688 \\
\hline & & & & Quatiguá & 7.045 & 71.508 & 112,689 & 62,52 & 0,714 \\
\hline & & & & TOTAL & 28.741 & 397.625 & 1116,483 & 148,69 & 3,511 \\
\hline & & & & MÉDIA & 5.748 & 13,835 & & 25,74 & 0,702 \\
\hline
\end{tabular}




\begin{tabular}{|c|c|c|c|c|c|c|c|c|c|}
\hline & Nome do Consórcio Público: & Estado & $\begin{array}{l}\text { Quantidade } \\
\text { de } \\
\text { municípios }\end{array}$ & $\begin{array}{l}\text { Quais os municípios } \\
\text { integrantes do } \\
\text { Consórcio? }\end{array}$ & População 2010 & PIB 2010 & \begin{tabular}{|l|} 
Área da \\
Unidade \\
territorial \\
$($ (km2) \\
\end{tabular} & $\begin{array}{l}\text { Densidade } \\
\text { demográfic } \\
\text { a (hab/km2) }\end{array}$ & \begin{tabular}{|l|} 
Índice de \\
Desenvolviment \\
o Humano \\
Municipal - 2010 \\
(IDHM 2010) \\
\end{tabular} \\
\hline \multirow{11}{*}{4} & \multirow{10}{*}{$\begin{array}{l}\text { Consórcio intermunicipal } \\
\text { caiuá ambiental }\end{array}$} & \multirow[b]{10}{*}{ PR } & \multirow[b]{10}{*}{10} & Alto Paraná & 13.663 & 134.656 & 407,719 & 33,51 & $\begin{array}{r}0,667 \\
\end{array}$ \\
\hline & & & & Amaporã & 5.443 & 62.988 & 384,735 & 14,15 & 0,669 \\
\hline & & & & Cruzeiro do Sul & 4.563 & 68.215 & 259,103 & 17,61 & 0,713 \\
\hline & & & & Mirador & 2.327 & 39.990 & 221,708 & 10,5 & 0,680 \\
\hline & & & & Paranavaí & 81.590 & 1.059 .157 & 1202,266 & 67,86 & 0,763 \\
\hline & & & & Santo Antonio do Caiuá & 2.727 & 31.414 & 219,068 & 12,45 & 0,696 \\
\hline & & & & São Carlos do Ivaí & 6.354 & 142.601 & 225,077 & 28,23 & 0,682 \\
\hline & & & & São João do Caiuá & 5.911 & 60.183 & 304,413 & 19,42 & 0,664 \\
\hline & & & & Tamboara. & 4.664 & 60.618 & 193,347 & 24,12 & 0,731 \\
\hline & & & & \begin{tabular}{|l|} 
Terra Rica \\
\end{tabular} & 15.221 & 194.675 & 700,587 & 21,73 & 0,710 \\
\hline & & & & TOTAL & 142.463 & 1.854 .497 & 4118,023 & 249,58 & 6,975 \\
\hline \multirow{11}{*}{5} & \multirow{10}{*}{$\begin{array}{c}\text { CONSÓRCIO } \\
\text { INTERMUNICIPAL DO } \\
\text { CONTESTADO - COINCO }\end{array}$} & \multirow[b]{10}{*}{ SC } & \multirow[b]{10}{*}{9} & MÉDIA & 14.246 & 13,017 & & 34,59 & 0,698 \\
\hline & & & & BRUNÓPOLIS & 2.850 & 50.879 & 337,044 & 8,46 & 0,661 \\
\hline & & & & CURITIBANOS & 37.748 & 589.850 & 948,738 & 39,79 & 0,721 \\
\hline & & & & FREI ROGÉRIO & 2.474 & 47.671 & 159,216 & 15,54 & 0,682 \\
\hline & & & & LEBON RÉGIS. & 11.838 & 206.415 & 941,486 & 12,57 & 0,649 \\
\hline & & & & \begin{tabular}{|l|} 
MONTE CARLO \\
\end{tabular} & 9.312 & 112.163 & 193,520 & 48,12 & 0,643 \\
\hline & & & & PONTE ALTA & 4.894 & 60.003 & 568,960 & 8,60 & 0,673 \\
\hline & & & & PONTE ALTA DO NORTE & 3.303 & 76.414 & 399,239 & 8,27 & 0,689 \\
\hline & & & & SANTA CECÍLIA & 15.757 & 259.279 & 1145,810 & 13,75 & 0,698 \\
\hline & & & & SÃO CRISTOVÃO DO SUL & 5.012 & 70.392 & 351,100 & 14,28 & 0,665 \\
\hline & & & & TOTAL & 93.188 & 1.473 .066 & 5045,113 & 169,38 & 6,081 \\
\hline & & & & MÉDIA & 10.354 & 15,807 & & 18,47 & 0,676 \\
\hline
\end{tabular}




\begin{tabular}{|c|c|c|c|c|c|c|c|c|c|}
\hline & Nome do Consórcio Público: & Estado & $\begin{array}{l}\text { Quantidade } \\
\text { de } \\
\text { municípios }\end{array}$ & $\begin{array}{l}\text { Quais os municípios } \\
\text { integrantes do } \\
\text { Consórcio? }\end{array}$ & População 2010 & PIB 2010 & $\begin{array}{l}\text { Área da } \\
\text { Unidade } \\
\text { territorial } \\
\text { (km2) }\end{array}$ & \begin{tabular}{|l|} 
\\
Densidade \\
demográfic \\
a (hab/km2)
\end{tabular} & \begin{tabular}{|l|} 
Índice de \\
Desenvolviment \\
o Humano \\
Municipal - 2010 \\
(IDHM 2010)
\end{tabular} \\
\hline \multirow{11}{*}{6} & \multirow{9}{*}{$\begin{array}{c}\text { Consórcio Intermunicipal } \\
\text { do Médio Vale do Itajaí - } \\
\text { CIMVI }\end{array}$} & \multirow[b]{9}{*}{ SC } & \multirow[b]{9}{*}{9} & Apiúna & 9.600 & 256.470 & 493,342 & 19,46 & 0,708 \\
\hline & & & & Ascurra & 7.412 & 103.204 & 110,901 & 66,83 & 0,742 \\
\hline & & & & Benedito Novo & 10.336 & 136.481 & 388,798 & 26,58 & 0,740 \\
\hline & & & & Doutor Pedrinho & 3.604 & 43.210 & 374,628 & 9,62 & 0,716 \\
\hline & & & & Indaial & 54.854 & 1.398 .852 & 430,790 & 127,33 & 0,777 \\
\hline & & & & Pomerode & 27.759 & 911.101 & 214,727 & 129,28 & 0,780 \\
\hline & & & & Rio dos Cedros & 10.284 & 173.675 & 554,077 & 18,56 & 0,729 \\
\hline & & & & Rodeio & 10.922 & 169.812 & 129,934 & 84,06 & 0,754 \\
\hline & & & & Timbó & 36.774 & 1.081 .097 & 127,405 & 288,64 & 0,784 \\
\hline & & & & TOTAL & 171.545 & 4.273 .902 & 2824,602 & 770,36 & 6,730 \\
\hline & & & & MÉDIA & 19.061 & 24,914 & & 60,73 & 0,748 \\
\hline \multirow{8}{*}{7} & \multirow{8}{*}{$\begin{array}{c}\text { Consórcio Intermunicipal de } \\
\text { Gerenciamento Ambiental } \\
\text { Iberí }\end{array}$} & \multirow{8}{*}{ SC } & \multirow[b]{7}{*}{7} & Águas de Chapecó & 6.110 & 125.141 & 139,83 & 43,7 & 0,713 \\
\hline & & & & Caxambu do Sul & 4.411 & 59.405 & 140,71 & 31,4 & 0,691 \\
\hline & & & & Chapecó & 183.530 & 3.932 .030 & 626,06 & 293,2 & 0,790 \\
\hline & & & & Cordilheira Alta & 3.767 & 118.244 & 82,86 & 45,5 & 0,747 \\
\hline & & & & Guatambú & 4.679 & 120.848 & 205,88 & 22,7 & 0,717 \\
\hline & & & & Planalto Alegre & 2.654 & 31.255 & 62,46 & 42,5 & 0,751 \\
\hline & & & & São Carlos & 10.291 & 160.548 & 161,29 & 63,8 & 0,769 \\
\hline & & & & TOTAL & 215.442 & 4.547 .471 & 1419,090 & 542,8 & 5,178 \\
\hline & & & & MÉDIA & 30.777 & 21,108 & & 151,82 & 0,740 \\
\hline
\end{tabular}

